\title{
El Jurista en el Nuevo Mundo
}

Pensamiento. Doctrina. Mentalidad

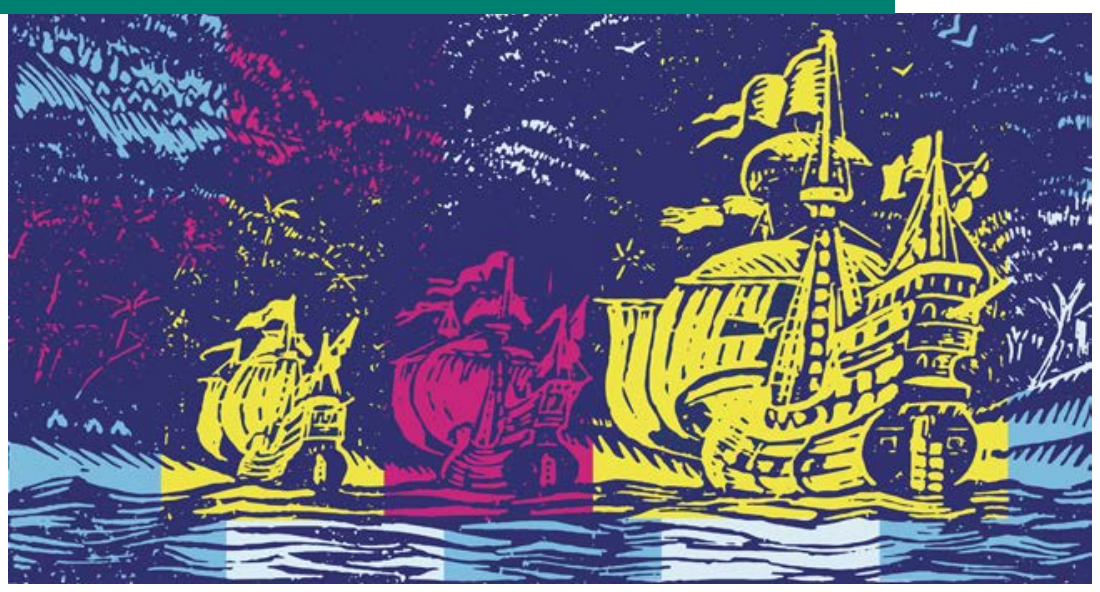



GLOBAL PERSPECTIVES
ON LEGAL HISTORY 


\title{
Global Perspectives on Legal History
}

\author{
A Max Planck Institute for European Legal History \\ Open Access Publication
}

http://global.rg.mpg.de

Series Editors: Thomas Duve, Stefan Vogenauer

\section{Volume 7}

Global Perspectives on Legal History is a book series edited and published by the Max Planck Institute for European Legal History, Frankfurt am Main, Germany.

As its title suggests, the series is designed to advance the scholarly research of legal historians worldwide who seek to transcend the established boundaries of national legal scholarship that typically sets the focus on a single, dominant modus of normativity and law. The series aims to privilege studies dedicated to reconstructing the historical evolution of normativity from a global perspective.

It includes monographs, editions of sources, and collaborative works. All titles in the series are available both as premium print-on-demand and in the open-access format. 
VÍCTOR TAU ANZOÁTEGUI

\section{El Jurista en el Nuevo Mundo}

Pensamiento. Doctrina. Mentalidad

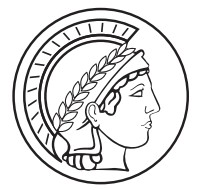

MAX PLANCK INSTITUTE

FOR EUROPEAN LEGAL HISTORY

2016 
ISBN 978-3-944773-06-3

eISBN 978-3-944773-16-2

ISSN 2196-9752

First published in 2016

Published by Max Planck Institute for European Legal History, Frankfurt am Main

Printed in Germany by epubli, Prinzessinnenstraße 20, 10969 Berlin

http://www.epubli.de

Max Planck Institute for European Legal History Open Access Publication

http://global.rg.mpg.de

Published under Creative Commons CC BY-NC-ND 3.0 DE

http://creativecommons.org/licenses/by-nc-nd/3.0/de

The Deutsche Nationalbibliothek lists this publication in the Deutsche Nationalbibliographie; detailed bibliographic data are available on the Internet at http://dnb.d-nb.de

Cover illustration:

Christian Pogies, Frankfurt am Main

(Illustration taken from: Gregorio de Robles, América a fines del siglo XVII. Noticias de los lugares de contrabando; Introducción de Víctor Tau Anzoátegui, Valladolid: Seminario Americanista de la Universidad de Valladolid, 1980, p. 10)

Recommended citation:

Víctor Tau Anzoátegui (2016), El Jurista en el Nuevo Mundo. Pensamiento. Doctrina. Mentalidad, Global Perspectives on Legal History, Max Planck Institute for European Legal History

Open Access Publication, Frankfurt am Main, http://dx.doi.org/10.12946/gplh7 


\section{Índice}

$\begin{array}{llllllllllllllllllllll} & P & & \end{array}$

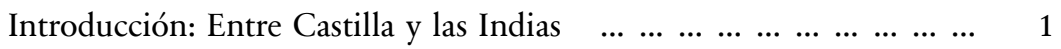

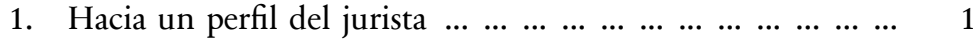

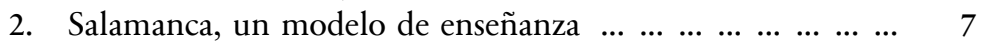

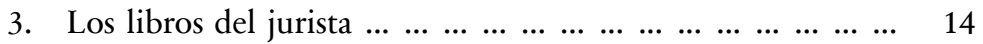

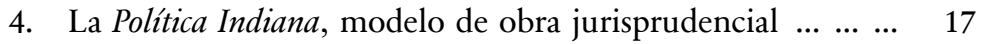

$\begin{array}{llllllllll}5 . & \text { Experiencia y prudencia en el jurista } & \ldots & \ldots & \ldots & \ldots & \ldots & \ldots & \ldots & \ldots\end{array}$

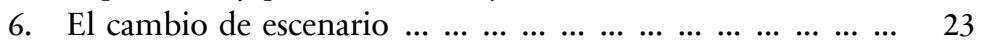

I La idea de Derecho en la colonización española en América $\ldots 25$

1. La plasticidad del Derecho trasplantado en las Indias $\ldots . . .25$

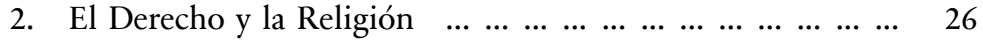

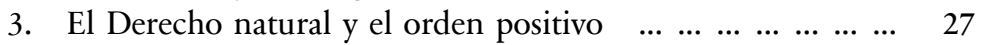

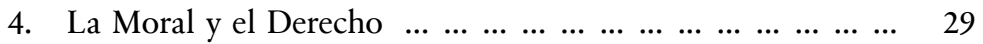

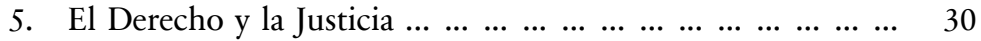

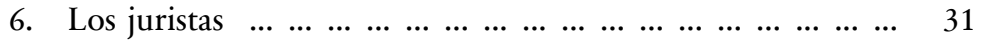

II ¿Humanismo Jurídico en el Mundo Hispánico? A propósito $\begin{array}{llllllllll}\text { de unas reflexiones de Helmut Coing } & \ldots & \ldots & \ldots & \ldots & \ldots & \ldots & \ldots & \ldots & \ldots\end{array}$

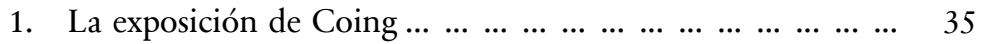

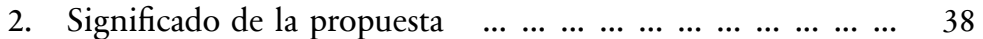

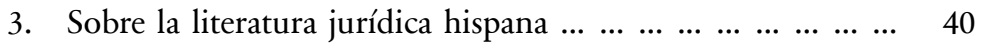

III El Gobierno del Perú de Juan de Matienzo. En la senda $\begin{array}{llllllllllllll}\text { del humanismo jurídico } & \ldots & \ldots & \ldots & \ldots & \ldots & \ldots & \ldots & \ldots & \ldots & \ldots & \ldots & \ldots & \ldots\end{array}$

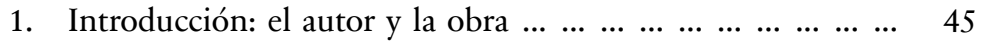

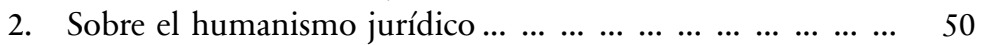

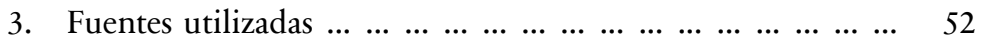

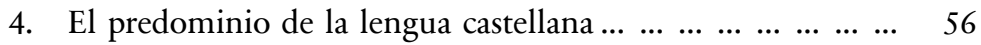

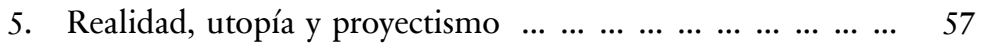

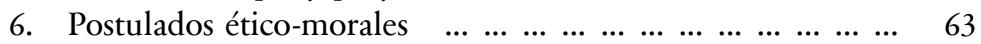




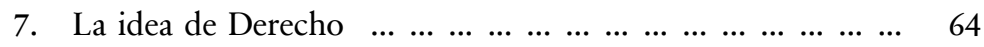

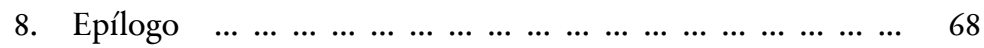

IV La Víctima Real Legal de Álvarez de Abreu en el pensamiento $\begin{array}{llllllllllllllllllllll} & \text { indiano } & \ldots & \ldots & \ldots & \ldots & \ldots & \ldots & \ldots & \ldots & \ldots & \ldots & \ldots & \ldots & \ldots & \ldots & \ldots & \ldots & \ldots & \ldots & \ldots & \ldots\end{array}$

1. Introducción...

$\begin{array}{lllllllllll}2 . & \text { El autor y la estructura de la obra } & \ldots & \ldots & \ldots & \ldots & \ldots & \ldots & \ldots & \ldots & \ldots\end{array}$

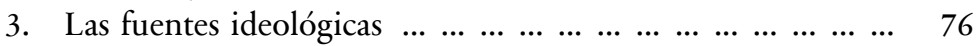

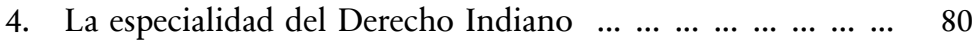

5. La grandeza de la Monarquía española y $\begin{array}{llllllllllll} & e l \\ \text { providencialismo político } & \ldots & \ldots & \ldots & \ldots & \ldots & \ldots & \ldots & \ldots & \ldots & \ldots & \ldots\end{array}$

6. $\quad \begin{array}{llllllllll} & \text { Los títulos de la conquista de Indias } & \ldots & \ldots & \ldots & \ldots & \ldots & \ldots & \ldots & \ldots\end{array}$

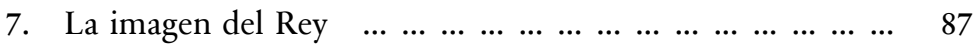

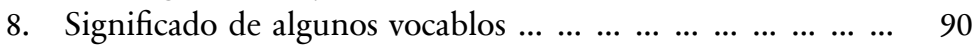

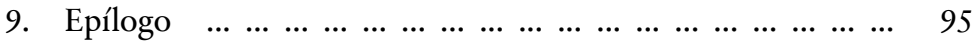

$\mathrm{V}$ La doctrina de los autores como fuente del

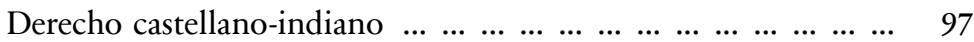

$\begin{array}{lllllllllllllll}\text { I. } & \text { Aproximación al tema } & \ldots & \ldots & \ldots & \ldots & \ldots & \ldots & \ldots & \ldots & \ldots & \ldots & \ldots & \ldots & \ldots\end{array}$

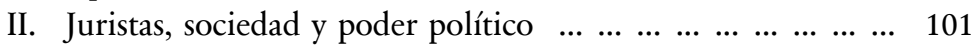

1. Opiniones y obras jurisprudenciales, ¿creadoras

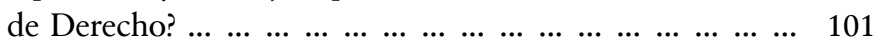

2. Opiniones y opiniones comunes. La auctoritas, $\begin{array}{lllllllllllllll}\text { como sustento } & \ldots & \ldots & \ldots & \ldots & \ldots & \ldots & \ldots & \ldots & \ldots & \ldots & \ldots & \ldots & \ldots & \ldots\end{array}$

3. El saber de los juristas: peso social e influjo político ... ... 108

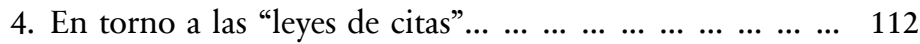

III. Vigencia de los autores en los siglos XVI y XVII.

$\begin{array}{llllllllllll}\text { Surgimiento de la crítica } & \ldots & \ldots & \ldots & \ldots & \ldots & \ldots & \ldots & \ldots & \ldots & \ldots & \ldots\end{array}$

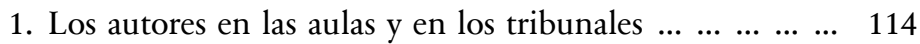

2. Opiniones y autores bajo la lupa crítica de profanos

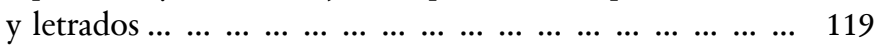

IV. Siglo XVIII: virulencia de la crítica y subsistencia

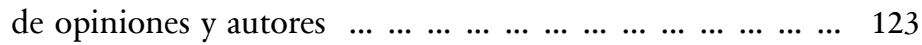

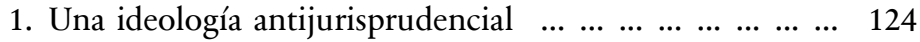

2. Otras expresiones y matices de la crítica

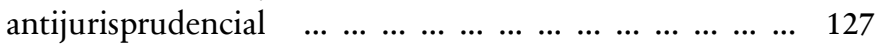

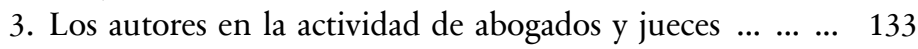


4. Hacia una creación jurídica sin opiniones ni autores $\quad \ldots \quad 139$

V. Los libros con auctoritas, fijadores de la jurisprudencia

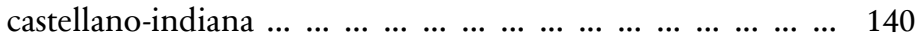

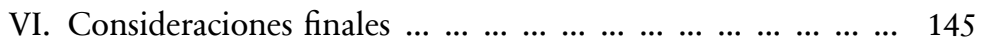

VI Entre leyes, glosas y comentos. El episodio de la Recopilación $\begin{array}{llllllllllllllllllll}\text { de Indias } & \ldots & \ldots & \ldots & \ldots & \ldots & \ldots & \ldots & \ldots & \ldots & \ldots & \ldots & \ldots & \ldots & \ldots & \ldots & \ldots & \ldots & \ldots & \ldots\end{array}$

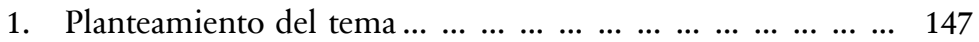

2. Leyes y autores, dos modos principales de establecer

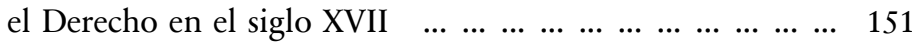

3. Las leyes entretejidas con los autores: ¿una recopilación $\begin{array}{lllllllllllllllll}\text { con glosas? } & \ldots & \ldots & \ldots & \ldots & \ldots & \ldots & \ldots & \ldots & \ldots & \ldots & \ldots & \ldots & \ldots & \ldots & \ldots & \ldots\end{array}$

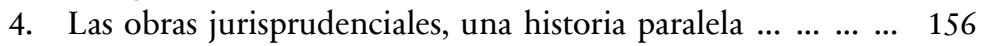

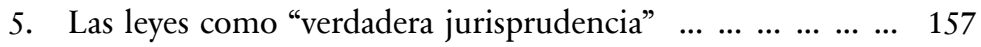

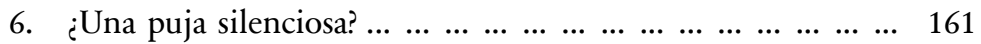

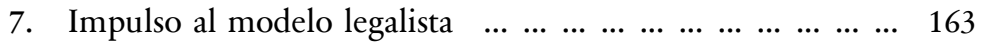

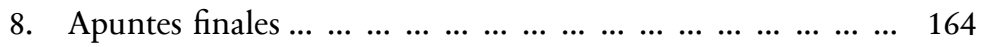

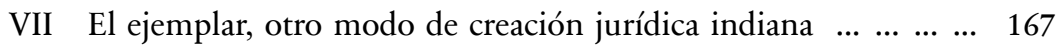

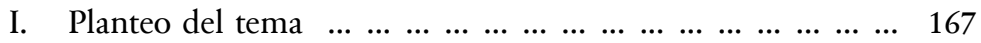

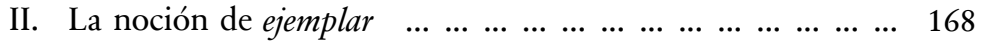

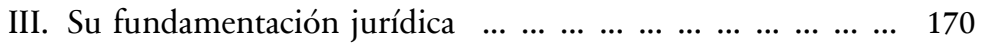

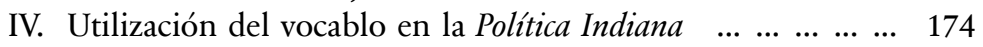

V. Uso e invocación en el despacho del Gobierno Supremo ... 178

1. La búsqueda de ejemplares, una tarea burocrática $\ldots . .178$

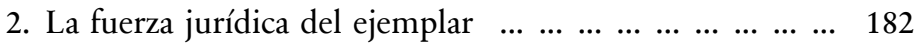

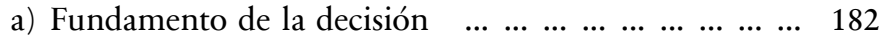

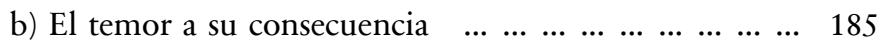

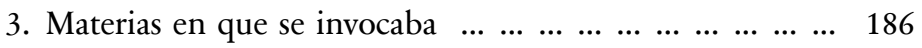

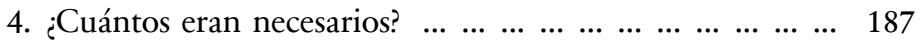

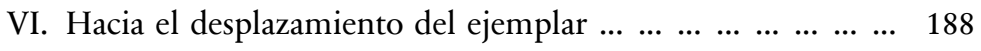

VIII La noción de Justicia en la Política Indiana de Solórzano... ... ... 193

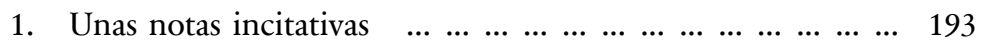

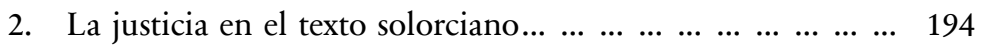

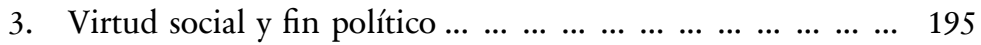

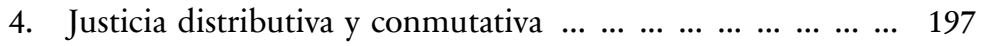

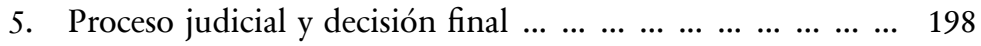




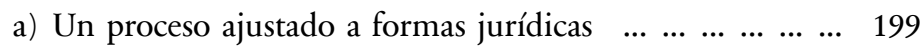

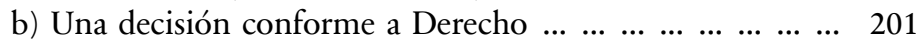

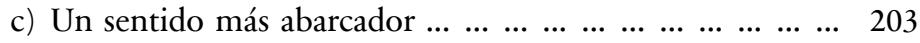

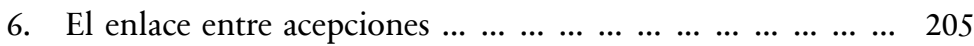

IX La variedad indiana, una clave de la concepción jurídica

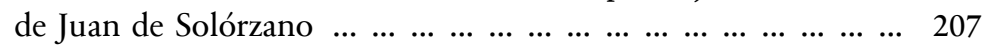

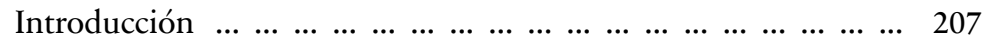

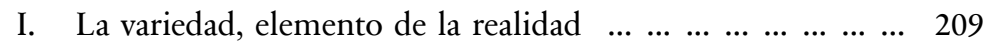

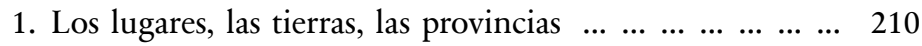

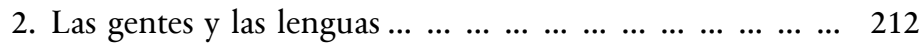

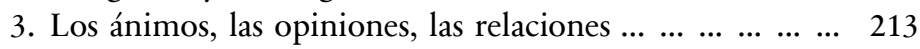

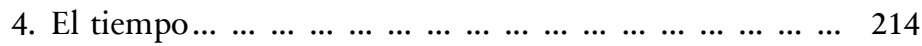

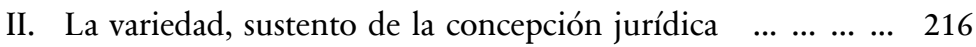

1. La variedad de costumbres ...

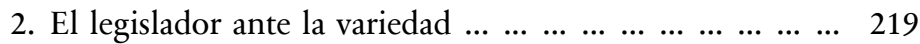

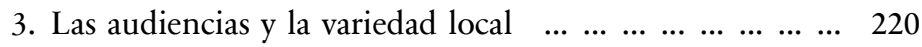

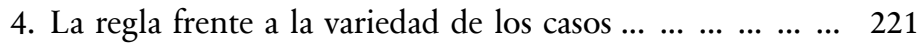

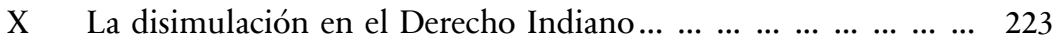

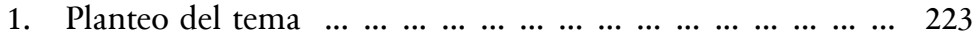

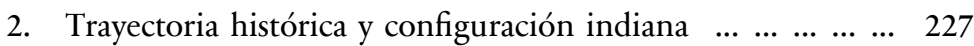

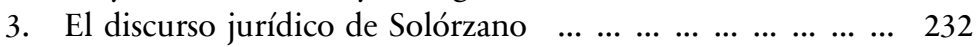

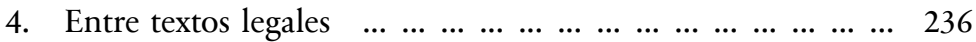

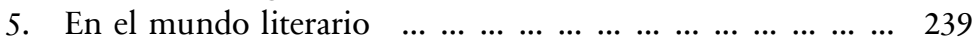

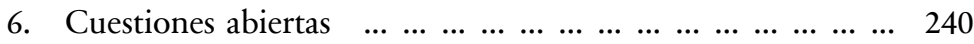

XI El Abogado del Cabildo de Buenos Aires durante el Virreinato 245

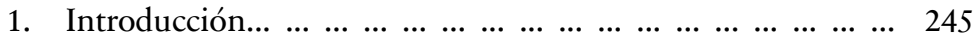

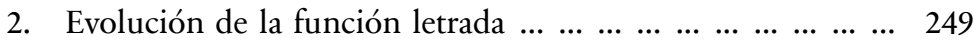

3. Denominación y caracterización de la función ... $\ldots . \ldots \ldots . . .258$

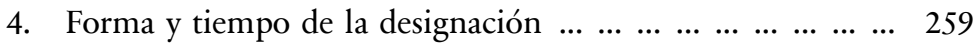

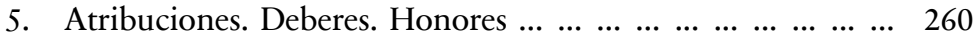

$\begin{array}{lllllllllllllllll}6 . & \text { La retribución } & \ldots & \ldots & \ldots & \ldots & \ldots & \ldots & \ldots & \ldots & \ldots & \ldots & \ldots & \ldots & \ldots & \ldots & \ldots\end{array}$

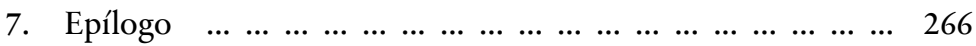




\section{Prólogo}

Si bien la figura del jurista asomaba ya en anteriores libros temáticos que he dedicado a las "fuentes del derecho indiano", como la ley y la costumbre, era necesario que ella fuese resaltada con un volumen propio que se ocupara específicamente del jurista castellano-indiano actuante en el Nuevo Mundo como partícipe en la formación y aplicación de un peculiar y novedoso orden jurídico. El enfoque aparece aquí encauzado por tres vocablos básicos: pensamiento, doctrina y mentalidad que establecen límites conceptuales dentro de un amplio campo intelectual.

Los trabajos que se reúnen aparecieron originariamente en revistas y obras colectivas editadas en diversos países, en su mayoría durante las décadas de 1980 y 1990 y mantienen sus títulos, estructuras y redacción con escasas modificaciones. Dada esa circunstancia se puede observar en ellos algunas reiteraciones de ideas y aún de expresiones, que se han conservado en esta edición ante la posible lectura independiente de los textos. Después de una atenta revisión, se han introducido sólo pequeños cambios, consistentes unos en la redacción y otros de índole bibliográfico. Asimismo se ha procurado la corrección de las erratas tipográficas deslizadas en las primeras versiones. El aparato erudito de cada uno mantiene su formulación originaria. Quiero en este punto consignar mi agradecimiento a la licenciada Laura Voldkin, del Instituto de Investigaciones de Historia del Derecho, por la inestimable colaboración prestada en la fatigosa tarea de revisión y transcripción de textos.

Como los trabajos reproducidos respondieron a diversos requerimientos de la vida académica, se podrá observar que la mayoría constituyen estudios monográficos propiamente dichos, abordados con la intención de dilucidar un punto o asunto científico o de determinar el uso de ciertos vocablos con contenido jurídico, acompañados del pertinente elenco de citas. Se incluyen también dos escritos, uno que apunta a ofrecer una visión panorámica sobre la idea de Derecho en la colonización española, y otro de carácter programático sobre la presencia del humanismo jurídico en el mundo hispano.

De esta compilación han quedado excluidos aquéllos estudios que, aun cuando reconocen conexión con la temática abordada, se encuentran publi- 
cados en mis libros sobre la ley y la costumbre, ya citados. También otros de elaboración posterior vinculados a nuevas líneas de investigación.

Es preciso tener en cuenta que la presencia del jurista castellano-indiano se hace notoria en otras obras de mi autoría, principalmente en Casuismo y Sistema (1992) y Nuevos horizontes en el estudio histórico del Derecho indiano (1997). Con respecto a la primera de esas obras, es ocasión para recordar que cuando la misma se encontraba en proceso de elaboración, algunos de los estudios aquí reunidos sirvieron de apoyo básico para abordar cuestiones que era preciso ahondar previamente, como el relativo a la doctrina de los autores, publicado en 1989. Otros puntos tratados en la misma obra fueron objeto de ampliación posterior - tal el caso de la variedad indiana - no faltando tampoco asuntos tan sensibles - como el de la disimulación que siendo allí apenas enunciado tuvo un extenso tratamiento años después. Son estas voces solo muestras de un extenso vocabulario del antiguo derecho civil y canónico, que resulta indispensable conocer para la comprensión del derecho indiano. En las Indias algunas de ellas experimentaron, bajo la mente y pluma de los juristas, un proceso de adaptación y renovación que alcanzó cierta magnitud.

Mi propósito es que, a través de estas páginas, se pueda observar el papel desempeñado por el jurista en el Nuevo Mundo como constructor y ejecutor de una ciencia y arte, puesta al servicio de la organización y desarrollo del poder público y de la sociedad nueva, enfrentando, en sus instancias temporales, realidades y situaciones tan diversas, como ellos mismos lo proclamaban. Con esta intención he preparado, especialmente para este volumen, el estudio introductorio bajo el título "Entre Castilla y las Indias", a fin de perfilar las características de ese jurista castellano-indiano que se formó y desenvolvió en aquella época de los grandes descubrimientos geográficos y que fue también de transformaciones de la cultura jurídica.

Mucho me honra la invitación efectuada por el profesor Thomas Duve para publicar este libro en la nueva serie "Global Perspectives on Legal History”, editada por el Max Planck Institute for European Legal History. Agradezco vivamente esta distinción conferida por tan apreciado colega y actual Director del Instituto. 


\section{Introducción: Entre Castilla y las Indias}

Sumario: 1. Hacia un perfil del jurista - 2. Salamanca, un modelo de enseñanza 3. Los libros del jurista - 4. La Política Indiana, modelo de obra jurisprudencial 5. Experiencia y prudencia en el jurista - 6. El cambio de escenario

\section{Hacia un perfil del jurista}

Hay varios vocablos para denominar a la persona dedicada al cultivo de la ciencia del Derecho en la teoría y en la práctica. Así acuden a nuestro encuentro las voces jurista, jurisconsulto, jurisprudente, jurisperito, legista, legisperito, letrado, abogado, con distintos matices, jerarquía y usos según los tiempos y las circunstancias. Entre ellas sobresale la de jurista, como la principal y más adecuada para el objeto de este trabajo, sin desconocer la existencia de otras voces de uso alternativo, como son especialmente las de jurisconsulto, letrado y abogado, cada una con su particularidad e historial.

En la búsqueda de un concepto que ayude a entender el papel del jurista como figura clave en los comienzos de la Edad Moderna he hallado en el conocido Tesoro de la Lengua Castellana de Sebastián de Covarrubias, impreso por primera vez en 1611, una definición muy interesante para esos fines. El artículo, además de etimológico, contiene unas preciosas referencias a la actividad mental y operativa del jurista con relación al Derecho de su tiempo. ${ }^{1}$

Es bueno recordar que Covarrubias, graduado en cánones, era un fino cultivador del léxico y solía colocar especial atención en la terminología jurídica, con un sentido culto y práctico a la vez, lo que dio a su trabajo no solo difusión sino también influjo sobre posteriores obras de su mismo género.

1 Sebastián de Covarrubias Orozco, Tesoro de la lengua castellana o española, ed. 1611. Edición moderna: Barcelona, 1943. Las siguientes citas de la obra se hacen por esta última edición. 
Covarrubias no dió a la voz jurista un lugar propio en su obra. La incluyó, con jerarquía particular, dentro del desarrollo de otro vocablo jurídico trascendente, el de justicia, en cuya explicación él acudió a los que denominaba "teóricos" y "juristas". Entre los primeros aparecen citados Cicerón, Aristóteles y Tomás de Aquino, en lengua latina; y entre los segundos, la mención directa es de los civilistas romanos, de los cuales recoge la idea de justicia como la perpetua y constante voluntad de dar a cada uno lo suyo.

Este respaldo de conocidas autoridades era seguido por una declaración suya explícita: "siempre que se tocare materia perteneciente a facultad, no es mi intención extenderme a más de lo que no puedo excusar, remitiéndome a los que exprofesso la tratan". Era en este espacio, que reservaba dentro del artículo para dar su opinión, donde introducía su propio aporte a la definición del término justicia, diciendo que "es la sustancia y el niervo de los juristas y el escopo de su facultad”. Es manifiesta aquí la intención de Covarrubias de exaltar la función del jurista y de dar proyección práctica al significado de justicia.

Se puede extraer del citado pasaje, algo enigmático, una doble apreciación. Por un lado, la justicia en cuanto considerada como el ser y esencia del jurista, que debía estar acompañada por el uso de fuertes razones para persuadir. Por otro lado, la introducción del término escopo (escoplo) - que designaba al instrumento de hierro acerado utilizado por el carpintero y el entallador - proponía la comparación con un noble oficio manual, en donde lucía la aptitud de destreza, proveniente de la conjunción del conocimiento y de la práctica cotidiana, que se aplicaba extensivamente a la ciencia y arte cultivado por el jurista. Espíritu y materia se funden en esta curiosa definición que muestra, con el ejemplo cotidiano, la tarea artesanal exigida al jurista de descubrir, establecer y adaptar las doctrinas y normas al caso que debía resolver.

La idea de Covarrubias tiene, a mi juicio, un relevante valor ilustrativo en el intento de penetrar en el meollo del oficio y es más viva y profunda que otras definiciones corrientes y más modernas. ${ }^{3}$ Dentro de una estudiada brevedad el autor buscaba abrir una senda explicativa que permitiese averiguar cómo operaba el jurista sobre la base de un saber propio y de unos atributos que estaban más allá del conocimiento estrictamente jurídico.

2 Ídem, p. 724.

3 Ídem, pp. 539, 581 y 724.

$2 \mid \quad$ Introducción 
Además, conviene recordar que la idea estaba pensada y ofrecida en una época en la que los juristas castellanos vivían múltiples situaciones dentro de la pluralidad de ordenamientos, prácticas y estilos que se daban en el ámbito de la extendida Monarquía, con reinos, provincias y territorios, tantos y tan diversos. Entre ellos, se ubicaba la peculiaridad indiana, por entonces ya ampliamente desenvuelta y conocida, sobre la cual resultaba claramente aplicable tal noción.

Para completar esta visión de Covarrubias es necesario acudir a su definición de Derecho que, con los particularismos propios ya conocidos, se constituyó en una noción difundida en diccionarios y vocabularios posteriores hasta fines del siglo XVIII. Después de un breve comienzo etimológico, y de una cita de las Sátiras de Horacio, llegaba al meollo conceptual que nos interesa bajo la frase aclaratoria de que Derecho "se toma algunas veces por lo que dispone y manda, o la naturaleza, el Príncipe, la ciudad, o el pueblo, o la gente, o la costumbre, de donde resultan el derecho natural, el de las gentes, el civil, los plebiscitos, y fueros, constituciones, ordenanzas, costumbres, etc." Y en nuevo apartado agregaba: "El derecho se divide en derecho divino y en humano: éste en derecho natural, el de las gentes, y el civil: ultra del cual tenemos el derecho canónico, por donde son juzgados los clérigos y cosas Eclesiásticas". Enseguida enumeraba el contenido normativo de este último derecho, con la aclaración final de que "de todo lo dicho se da razón en sus lugares propios, y por esto va aquí atropellado" ${ }^{4}$

Debajo de esta aparente sencillez, encerrada en una mera descripción que distinguía varias categorías, se encontraba una rica y compleja materia que debía atender el jurista en su búsqueda de aquella "justicia”, que era el objeto de su labor, según lo había expresado anteriormente.

La definición de Covarrubias permite avanzar dentro del contexto social castellano, en el cual crecía en importancia la presencia y actuación del elemento letrado. La nueva organización del poder público, que se consolidaba en torno a la figura del rey, tenía su basamento en la "burocracia", en cuyo núcleo participaban un conjunto de juristas que validos de su saber, ejercían un moderado poder, compartido con grandes señores, prelados, diplomáticos y hombres de guerra. Los trabajos de Salustiano de Dios sobre las ideas y actuación de los juristas castellanos en los siglos XV a XVII son 
importantes a los fines de entender muchas actitudes de los juristas indianos, sobre todo en la conformación del poder político y en la exaltación de la dignidad regia frente a otras potestades. ${ }^{5}$

Sostiene Maravall que en el siglo XVII los letrados constituían "una capa de población bien caracterizada por la apropiación de unas funciones especializadas, por el reconocimiento de unos valores y virtudes, por la práctica de un modo de vida" y también "por la atribución de unos caracteres que acaban de completar el estereotipo común de cuantos pertenecen al grupo" ${ }^{6}$ Según Covarrubias, los letrados se distinguían entre los ciudadanos que habitaban la ciudad y ocupaban "un estado medio" entre los caballeros y los oficiales mecánicos. ${ }^{7}$

El campo de conocimiento y actuación del jurista abarcaba tanto las leyes civiles como las canónicas. El Derecho común era una integridad que se imponía al jurista, sobre todo en el orbe hispano de los siglos XVI y XVII. El proverbio de Ludovico Romano en el sentido de que "las leyes sin los cánones valen poco; pero los cánones sin las leyes nada" representa esa creencia generalizada. Bermúdez de Pedraza decía que el buen jurista ha de saber ambos derechos porque "son como un par de guantes, que el uno sin el otro es de poco provecho; no basta saber el Derecho Civil para ser perfecto jurista, es preciso que sepa también el Canónico". ${ }^{8}$ Esta creencia llevaba a Juan de Matienzo, en el siglo XVI, a disculparse por ingerirse en hablar de cosas de Iglesia ya que - decía - "nuestra profesión es Derecho Canónico y Civil".

Según Francisco Carpintero, pese a que en el jurista medieval se percibieron entrelazamientos entre las cosas divinas y humanas, existía ya entonces una clara delimitación entre el Derecho y la Teología. Esta separación - para dicho autor - paradójicamente se perdió en los inicios del naturalismo

5 Jean-Marc Pelorson, Los letrados juristas castellanos bajo Felipe III. Investigaciones sobre su puesto en la sociedad, la cultura y el Estado, Valladolid, Junta de Castilla y León, 2008 (Edición francesa en 1980), pp. 11-27; Salustiano De Dios, El poder del monarca en la obra de los juristas castellanos (1480-1680). Ed. Universidad de Castilla-La Mancha, Cuenca 2014.

6 José Antonio Maravall, Poder, honor y élites en el siglo XVII, Madrid, 1979, pp. 287-293.

7 Covarrubias, Tesoro..., pp. 427-428.

8 Francisco Bermúdez de Pedraza, Arte legal para estudiar la jurisprudencia, 1612, p. 59.

9 Juan de Matienzo, Gobierno del Perú (1567), Edición de Guillermo Lohmann Villena, París-Lima, 1967, p. 333.

4 Introducción 
moderno, como en el caso de Hugo Grocio que acudía a la Biblia como tópico frecuente de sus argumentos jurídicos. ${ }^{10}$ En donde ese fenómeno se percibe con claridad es en el mundo hispano, dado que el Derecho común resultaba insuficiente para dar solución a los problemas que planteaba la conquista del Nuevo Mundo. Entonces el Derecho natural cultivado por los teólogos asumió un papel directivo. ${ }^{11}$ Un jurista, con buena experiencia indiana, como el aragonés Juan Luis López señalaba a fines del siglo XVII "la manifiesta y grande conexión que tienen entre sí la Teología y los derechos canónicos y civil", al punto que muchas veces los juristas deben avanzar a considerar puntos teológicos, y los teólogos deben a su vez penetrar en cuestiones jurídicas. ${ }^{\mathbf{1 2}}$ Esto llevó a considerar como juristas a teólogos en cuanto estudiaban la ley natural establecida por Dios, que contenía principios superiores y fundamentales que prevalecían sobre la ley positiva humana. ${ }^{13}$

Castilla era el reino organizado que regía el proceso de expansión atlántica hacia tierras y gentes hasta entonces desconocidas por el hombre europeo. El jurista que operaba en esas circunstancias tenía una matriz castellana por su formación universitaria, por el ámbito cultural que lo rodeaba, y por la misma estructura de los órganos de gobierno y justicia del Reino. El enfrentamiento con una realidad que era en muchos aspectos distinta de la peninsular - como claramente se puede leer en testimonios de conquistadores, misioneros y autoridades ya de la primera época - llevaba a los juristas a buscar soluciones a los problemas nuevos que se planteaban. Se daba así paso a la creación de lo que, con el transcurso de los años, configuraría un corpus normativo de heterogénea composición, tanto en lo civil como en lo canónico. A tal punto quedaron marcadas esas diferencias, que llegó a tenerse entonces por verdad sabida que el orden indiano no podía alcanzar a ser

10 Francisco Carpintero, "El derecho natural laico de la Edad Media. Observaciones sobre su metodología y conceptos”, en Revista de Estudios Histórico-Jurídicos, núm. 6, Valparaíso, 1981, pp. 261-262.

11 Véase Alfonso García-Gallo, "El derecho común ante el Nuevo Mundo", en Estudios de Historia del Derecho Indiano, Madrid, 1972, pp. 147-166.

12 Juan Luis López, "Observaciones theopolíticas en que se ilustran varias leyes de la Recopilación de Leyes de los reinos de las Indias”, Lima, 1689, manuscrito en Biblioteca Universitaria de Sevilla, est. 330, núm. 132, t. I, fs. 212v-213.

13 Alfonso García-Gallo, "Las Casas, jurista”, en Instituto de España, Sesión de apertura del curso académico 1974-75, Madrid, 1975, pp. 53-77. En especial, pp. 56-57. 
plenamente entendido y asumido por los consejeros de Castilla ni tampoco por los letrados que viajaban a las Indias sin tener experiencia en este particular Derecho. Era este último un argumento eficaz que solían esgrimir con más fuerza al paso del tiempo - los letrados criollos para obtener plazas en el gobierno y justicia locales frente a idénticas aspiraciones de sus colegas peninsulares.

Los juristas nacidos o radicados en las provincias indianas solían descubrir el "discurso constitucional" del reino, es decir la trama que se iba construyendo, no de un modo teórico, sino bajo el impulso de las respuestas que cabía dar a las múltiples cuestiones suscitadas. Si bien en las Indias circulaba y estaba viva una literatura jurídica castellana que ejercía un fuerte influjo, las preferencias por los autores o cuerpos legales eran distintas y también lo eran las lecturas e interpretaciones que se hacían de ellos. Diversos criterios se fueron formando con carácter general o particular. Así, por ejemplo, "las circunstancias locales" fueron alegadas muchas veces en punto a la aplicación de normas generales; y el "trasfondo consuetudinario" fue tenido en cuenta en el mismo sentido. En el campo penal se observó en algunas audiencias, al menos, un arraigado sentimiento de benignidad en la práctica judicial, mediante la vía del arbitrio judicial. ${ }^{\mathbf{1 4}}$ En fin, el uso de voces o figuras jurídicas y hasta la predilección colectiva de los indianos por las Partidas ${ }^{15}$ marcan también esa distinción que los juristas fueron plasmando en sus creaciones.

El mismo concepto de "cultura jurídica" en América puede ofrecer diferentes apreciaciones, como lo señala Tamar Herzog, quien desde sus indagaciones sobre el reino de Quito, afirma que en los siglos XVI al XVIII dicha cultura "incluía, ante todo, la Biblia y los ensayos y tratados de teología, siendo el Ius commune una fuente secundaria y de menor importancia dentro de ella", agregando que "la vida jurídica seguía dominaba por nociones y reglas directamente adaptadas del universo de la religión”. ${ }^{\mathbf{P}}$

14 María Luz Alonso, "Un jurista indiano: Juan Antonio Torquemada”, en Justicia, Sociedad y economía en la América Española, Valladolid, 1983, pp. 225-226.

15 Bernardino Bravo Lira, "Vigencia de las Partidas en Chile", en REHJ, núm. 10, 1985, pp. $43-105$.

16 Tamar Herzog, "Sobre la cultura jurídica en la América colonial (siglos XVI-XVIII)", en Anuario de Historia del Derecho Español, vol. LXV, Madrid, 1995, p. 911. 
Tras esta caracterización del jurista castellano-indiano, se abren una serie de interrogantes. Así, por ejemplo: cuáles eran los ámbitos intelectuales y públicos en los que se formaba y actuaba; qué líneas de pensamiento o mentalidad dominaba su actividad; hasta qué punto su accionar iba moldeando al Derecho en su creación y aplicación mediante la introducción de antiguos y nuevos elementos en el discurso jurídico; quiénes y cómo trasladaban, adoptaban e innovaban la cultura del Ius commune en los nuevos espacios geográficos. ${ }^{\mathbf{1 7}}$

\section{Salamanca, un modelo de enseñanza}

Una afirmación iushistoriográfica, trasmitida superficialmente de unos a otros autores, sostenía que el Derecho que se enseñaba en las universidades hispanas consistía en volcar en las aulas el contenido de los principales cuerpos del derecho romano, dispuestos en cátedras de Instituta, Código y Digesto, con omisión o desplazamiento de la normativa del reino, la cual sólo se conocía y aprendía posteriormente junto con la práctica del foro. Esta situación que acompañó el florecimiento de aquellos estudios en las principales universidades castellanas, como la de Salamanca durante el siglo XVI y primera mitad del XVII, sólo se habría modificado con el avance del siglo siguiente cuando para detener la declinación en que habían caído los estudios universitarios en Castilla, se hizo sentir una mayor presión de las autoridades reales para que el Derecho regio alcanzara, de menor a mayor, un lugar ascendente en las aulas, reflejada también en la literatura jurídica. Esta misma caracterización se aplicaba a las universidades americanas a partir de las primeras creadas, en 1551, en México y Lima.

De esta explicación no parecía creíble que durante tanto tiempo se hubiese vivido una experiencia docente tan singular, como era la fractura

17 En este último sentido destaco la obra de Aldo Andrea Cassi, Ius Commune tra Vecchio e Nuevo Mondo. Mari, Terra, Oro nell Diritto della Consquista (1492-1680), Milano, Giuffrè, 2004. Sobre este libro puede verse la reseña bibliográfica que publiqué en Quaderni Fiorentini per la Storia del Pensiero Giuridico Moderno, núms. 33-34, Firenze, 2004-2005, pp. 1187-1195. También Víctor Tau Anzoátegui, "El Derecho Indiano en su relación con los derechos castellano y común", en Hispania. Entre derechos propios y nacionales, edición a cargo de Bartolomé Clavero, Paolo Grossi y Francisco Tomás y Valiente, Milano, Giuffrè, 1990, t. II, pp. 573-591. 
entre un Derecho excluyentemente romano proclamado en las aulas y otro regio, practicado en el foro. Las historias universitarias publicadas entonces se ocuparon en describir la vida externa de la institución con abundantes datos acerca de su fundación, constitución, reglamentos, cátedras, autoridades y profesores, actos y ceremonias, pero con escasa inserción en su pensamiento vivo, en el influjo sobre el Derecho y en el mensaje que inculcaban a los estudiantes y graduados. ${ }^{\mathbf{1 8}}$

En las últimas décadas, estudios renovadores han permitido revisar estos juicios y alcanzar conclusiones distintas a las existentes. Entre ellos se destaca, con respecto a la Universidad de Salamanca, una línea de investigación desenvuelta por la profesora María Paz Alonso Romero que, a partir de 1991, ha publicado varios estudios relevantes, hoy reunidos en su libro Salamanca, escuela de juristas. ${ }^{19}$

La nueva tesis ofrecida, avalada con una sólida documentación procedente de archivos universitarios, es que, contrariamente a lo sostenido por historiadores anteriores, en la Universidad de Salamanca se preparaba a los juristas que salían de sus aulas para el ejercicio de la profesión forense con el conocimiento de la realidad jurídica de su tiempo y de los elementos que la componían. La base doctrinal estaba en el Corpus iuris, que los catedráticos leían en fragmentos escogidos y comentaban en relación al caso presentado siguiendo las alternativas y variantes ofrecidas por autores antiguos y modernos para adiestrar a los estudiantes en la consideración de los problemas jurídicos y la articulación de la argumentación en torno al caso. Esta era considerada como principal actividad de los estudiantes en el aula. Pero asimismo se instruía a los aspirantes en el ordenamiento del reino, que daba especial preferencia al derecho regio, cuando contenía algún precepto relativo al caso tratado, criterio éste que no era entonces discutido. ${ }^{20}$

18 Un interesante examen crítico en el sentido indicado en el texto puede verse en Pelorson, Los letrados juristas..., cit., pp. 33 y ss. Para una visión general, véase Agueda Rodríguez Cruz, "La proyección de la Universidad de Salamanca en Hispanoamérica”, en La Universidad ante el Quinto Centenario. Actas del Congreso Internacional de Universidades, Editorial Complutense, Madrid, 1991, pp. 179-191.

19 María Paz Alonso Romero, Salamanca, escuela de juristas. Estudio sobre la enseñanza del derecho en el Antiguo Régimen, Universidad Carlos III, Madrid, 2012.

20 María Paz Alonso Romero, "Lectura de Juan Gutiérrez”, en ídem, Salamanca..., cit., pp. 466-469.

8 Introducción 
Según Paz Alonso, los grandes comentaristas del Derecho castellano en el siglo XVI se formaron en Salamanca y también enseñaron en sus aulas. Todos ellos tuvieron presentes el Derecho regio en las aulas, en obras y en la práctica tribunalicia. De tal modo, concluye que ni la Universidad enseñó una cultura jurídica ajena ni existía en Castilla una práctica desconectada de los saberes enseñados en las aulas. Como ejemplo relevante de esta afirmación, dicha profesora ha presentado la interesante figura del jurista Juan Gutiérrez, de notoria actividad a fines del siglo XVI y principios del XVII, preocupado ante todo por la dimensión práctica del Derecho y su capacidad para resolver conflictos. ${ }^{21}$ Así en Salamanca - que fue el principal centro de estudios jurídicos de la Monarquía al menos durante el siglo XVI y primera mitad del siglo XVII - se aprendía y cultivaba un Derecho efectivamente vigente, que era el común, el regio y el judicial, bajo el principio de que el Derecho aplicable era el regio mientras que el común, encarnado en el Corpus iuris, actuaba como indispensable base doctrinal. ${ }^{22}$

En general, puede sostenerse que la formación jurídica que se ofrecía en las universidades hispanas en los primeros siglos de la Edad Moderna consistía en el estudio de los derechos romano (en cátedras de Instituta, Código y Digesto) y canónico (en cátedras de Decreto y Decretales). Los profesores ejercían su enseñanza a partir de la lectura y comentarios de textos selectivos de esos cuerpos, en materias y cuestiones principales, con el objeto de introducir a los estudiantes en el manejo del instrumental dialéctico y argumentativo para la solución de casos y conflictos que se presentasen. Se concebía así un aprendizaje activo de los textos, que se extendía al conocimiento de sus glosas, al uso de autores modernos y a la concordancia con las Partidas, dando así lugar a una fase práctica de esa enseñanza.

Este criterio didáctico estaba expuesto en los estatutos y reglamentos universitarios pero de manera más explícita se observa en unos breves escritos que circulaban en Castilla a fines del siglo XVI y primera mitad del XVII, denominados "Forma o modo de pasar en Derecho", en los cuales se daban precisas instrucciones a los pasantes sobre la manera con que debían encarar su estudio con vistas a los exigentes exámenes requeridos para alcanzar el grado de licenciado. En un detallado programa se establecía el tiempo que

22 Ídem, pp. 466-469. 
debía dedicar al estudio y los textos a utilizar, con diversas recomendaciones, entre las cuales sobresalía la advertencia de que la tarea consistía en "ver muchos textos y entenderlos".

Estamos en presencia de una concepción del Derecho encabezada por la doctrina de los cuerpos romanos y canónicos - así lo testimonia la denominación de las cátedras - pero limitada por la intensa labor posterior de glosadores y autores más modernos y por la fuerza que fueron adquiriendo los derechos propios, como en Castilla el Fuero Real, las Partidas, las Recopilaciones, los fueros y costumbres. El Derecho se desarrolló pues como un saber jurisprudencial, diverso y variable, que no quedaba encerrado en fórmulas y soluciones inmutables. Si bien el texto romano gozaba de autoridad, se instruía al principiante para que sobre el mismo plantease sus dudas y dificultades recurriendo a la opinión de la dificultosa glosa y de autores modernos para su aplicación al caso en un ejercicio en que aparecían entramadas las dimensiones teóricas y prácticas. No era pues un aprendizaje pasivo de textos antiguos. Estos mantuvieron siempre un lugar principal por su autoridad, sin quedar menoscabados por su falta de aplicación a situaciones particulares, dada la impronta casuista que dominaba el ordenamiento.

Como se advierte, el aprendizaje y la aplicación del Derecho eran una actividad de estudio y práctica que exigía tareas de búsqueda e indagación, de articulación de textos y de construcción de discursos y doctrinas, por parte del jurista. Era lo que Covarrubias habría tenido en mente para preparar aquella recordada definición, que a primera vista surgía como enigmática y que ahora, con las precedentes explicaciones, puede considerarse como elocuente y precisa.

Bajo este modelo de enseñanza, los juristas se encargaron de elaborar las primeras normas indianas que se formularon dentro del Derecho de Castilla. Bien pronto esa normativa empezó a adquirir un rango especial, a medida que las lejanas provincias se fueron incorporando a la corona castellana, con órganos propios de gobierno y justicia. Eran pues esos juristas castellanos los que asistían, entre dudas y desconciertos, a las primeras experiencias que sucedían a los grandes descubrimientos atlánticos del siglo XVI. ${ }^{23}$ Estos

23 Una interesante descripción de las dificultades para implantar la función de justicia en los primeros tiempos de la colonización en Mario Góngora, El Estado en el Derecho indiano. Época de fundación (1492-1570), Santiago de Chile, 1951, pp. 222 y ss. En el mismo senti- 
hechos aparecen indudablemente integrados en la mente de un Covarrubias cuando diseñaba su imagen del jurista, que era en nuestro caso, propiamente castellano-indiano. Ensamble que, bajo distintas características e intensidad, se mantuvo a lo largo del tiempo de la dominación española.

Como explica Pelorson, estos juristas castellanos sirvieron a la Corona en los distintos reinos, provincias y demás territorios que conformaron la Monarquía Española en esos siglos de la Edad Moderna. ${ }^{24}$ En particular, eran numerosos los que aspiraban y obtenían plazas en los gobiernos y tribunales indianos. El modelo de la Universidad de Salamanca se implantó en las universidades que se fueron creando en el Nuevo Mundo a partir de las establecidas, en 1551, en Nueva España y Perú, con el arribo de los letrados-juristas y teólogos graduados en la Península.

Algunos datos relevantes permiten sostener que, junto a la aplicación de la normativa proveniente del Derecho común y castellano, surgió en los claustros universitarios la preocupación por los nuevos problemas jurídicos suscitados en los territorios descubiertos. Ejemplo de ello son las enseñanzas de fray Alonso de la Veracruz en la naciente Universidad de México sobre el candente asunto de la encomienda y la propiedad territorial, que en 1553-1555 quedó plasmado en un tratado compuesto de once dudas. Veracruz, discípulo de Vitoria en Salamanca, trataba allí el conflicto de intereses entre indios y españoles en la cuestión, buscando orientarlo por los principios del Derecho natural. ${ }^{25}$ Esta influencia teológica-jurídica se hizo parte del pensamiento universitario de la época. ${ }^{26}$

Según referencias posteriores se puede vislumbrar la presencia en esos ámbitos de las Partidas, reconocidas como el cuerpo real más relevante de Castilla, que fue texto de vanguardia en esta penetración, con una predilección especial en las provincias indianas. Bajo su sombra se fueron introduciendo en los claustros las propias normativas relativas al Derecho de Indias,

do véase José María García Marín, La Justicia del Rey en Nueva España, Universidad de Córdoba, Córdoba, 2011.

24 Pelorson, Los letrados juristas..., cit., p. 17.

25 Silvio Zavala, "Fray Alonso de Veracruz, primer profesor de Derecho agrario en la incipiente Universidad de México", en La Universidad ante el Quinto Centenario, Actas del Congreso Internacional, Editorial Complutense, Madrid, 1992, pp. 49-53.

26 Véase al respecto, las interesantes consideraciones que se hacen sobre el contenido de la enseñanza en Lucio Mendieta y NúñEz, Historia de la Facultad de Derecho, México, 1956, pp. 86-92. 
ofrecidas a través de las principales obras legales y jurisprudenciales que empezaron, con el tiempo, a aparecer y circular. Entre ellas puede mencionarse por su difusión y relevancia en toda América, a la Política Indiana de Solórzano.

El trasplante del modelo salmantino al Nuevo Mundo, en cuanto al sentido de la enseñanza jurídica, puede observarse, por ejemplo, en el elogio que se hacía de un catedrático novohispano del siglo XVI que explicaba y declaraba normas pontificias. El testimonio aseveraba que dicho profesor era "copioso en los argumentos estériles, conciso en los abundantes, pronto en las citas, sutil en las deducciones", agregando que "presenta sofismas y los deshace, nada ignora de cuanto hay más oscuro y elevado en Derecho, y por decirlo de una vez, es el único que puede hacer jurisconsultos a sus discípulos". 27

En el vastísimo reino del Perú, la Universidad de San Marcos se destacó como centro formativo de juristas y abogados, con presencia mayoritaria de los criollos a partir de 1580 a raíz del impulso dado por el virrey Toledo a los estudios superiores. Durante el siglo XVII tanto en el foro como en la estructura de gobierno y justicia, se fue consolidando el grupo de los abogados criollos provenientes de familias limeñas y también de otras comarcas del Nuevo Mundo. ${ }^{28}$ Es precisamente en esa centuria cuando se acabó de configurar "el derecho municipal del Perú", debido a la acción gubernativa de varios virreyes y a la labor fijadora, de orden legislativa y jurisprudencial, de algunos destacados juristas locales, como Gaspar de Escalona y Agüero, y Tomas de Ballesteros, y de otros orígenes como Pedro Frasso y Juan Luis López. $^{29}$

27 Javier Malagón Barcelo, "Breve reseña histórica de la Escuela Nacional de Jurisprudencia”, en Estudios de Historia y Derecho, México, 1966, p. 222.

28 Teodoro Hampe Martínez, "Los abogados de Lima colonial. Una perspectiva cultural y social de la profesión legal”, en Homenaje a Alberto de la Hera. José Luis Soberanes Fernández y Rosa María Martínez de Codes (coords.), México, Universidad Nacional Autónoma de México, 2008, pp. 403-419. La cita en p. 418.

29 Ismael Sánchez Bella, "Notas sobre Gaspar de Escalona y Juan Luis López, juristas del Virreinato peruano", en Revista Chilena de Historia del Derecho, núm. 6, Santiago (Chile), 1970, pp. 217-237. Sobre el tema, véase Víctor Tau Anzoátegui, "El derecho municipal del Perú. Apuntes sobre su configuración”. Reeditado en el volumen de ídem, La Ley en América Hispana. Del Descubrimiento a la Emancipación, Academia Nacional de la Historia, Buenos Aires, 1992, pp. 311-345. 
El modelo docente, con variantes y altibajos, atravesando esplendores y decadencias subsistió en el mundo hispano hasta el siglo XVIII, y aún más, pero ya la situación había empezado lentamente a modificarse con la fuerza ostentosa que adquiría el Derecho real en las aulas en detrimento del Derecho romano, que se replegó sin desaparecer como saber doctrinal. Fue entonces notoria la aparición de nuevas denominaciones en las cátedras, donde empezaron a ser reemplazados los títulos de los cuerpos romanos por los del derecho regio. En esta línea, el Derecho indiano no quedó atrás. Por ejemplo, en Lima se encaró la composición de una Instituta para su enseñanza, que, si bien no llegó a concretarse, es un interesante testimonio de la nueva tendencia. ${ }^{30}$ Otro intento, que al final no prosperó, fue el establecimiento hacia 1786 de una academia de jurisprudencia en Granada dedicada exclusivamente al estudio del derecho indiano. ${ }^{31}$ Tiempo después, José María Alvárez, jurista de Guatemala, elaboró las Instituciones de derecho real de Castilla e Indias, obra de lograda síntesis de la cultura jurídica castellanoindiana de ese tiempo, que a partir de 1818 alcanzó, a través de varias ediciones, una extendida influencia en el horizonte hispano, con interesante proyección en el período de transición de la primera mitad del siglo XIX. ${ }^{32}$

En esta época se introdujeron nuevos criterios en la enseñanza que postulaban un conocimiento racional y sistemático del saber jurídico y estimulaban la formulación de un Derecho uniforme y abstracto. Ello llevó a la elaboración de grandes panoramas o síntesis y a la organización de sistemas jurídicos. Se le atribuía al antiguo modelo un excesivo apego al derecho romano y un rígido carácter teórico que, supuestamente, lo habría mantenido durante mucho tiempo ajeno a la práctica y vida jurídica que lo rodeaba. Surgió así una literatura de manuales u obras generales destinados a modificar el esquema mental del jurista para adaptarlo al cambio profundo que ya estaba en ciernes en la concepción del Derecho.

30 Víctor Tau Anzoátegui, El taller del jurista, Universidad Carlos III de Madrid, 2011, pp. $164-165$.

31 José M. Mariluz Urquijo, “Una academia de derecho indiano bajo Carlos III”, en Revista del Instituto de Historia del Derecho, núm. 7, Buenos Aires, 1955-56, pp. 83-92.

32 Véase al respecto el estudio de Jorge Mario García laguarda y María del Refugio GonzÁLEz, "Significado y proyección hispanoamericana de la obra de José María Alvarez", estudio preliminar de la edición de la obra Instituciones de derecho real de Castilla y de Indias publicada en 1982 en México por la Universidad Nacional Autónoma de México. 
Sin embargo, hacia la segunda mitad del siglo XVIII el antiguo modelo tenía todavía una notoria presencia, en coexistencia con las nuevas ideas, como ocurrió en Salamanca con ciertas prácticas universitarias y con la adopción del nuevo Plan de Estudios de 1771. En Nueva España, por ejemplo, se mantenía como requisito para acreditar las dotes de un catedrático su modo de disertar en el aula a la antigua usanza sobre la base de los textos canónicos y civiles. ${ }^{33}$

\section{Los libros del jurista}

La compañía del libro se hizo necesaria para el buen jurista. El abogado perfecto - decía un autor castellano del último cuarto del siglo XVII requiere de muchos y diversos libros para el estudio de las materias o puntos, y para conocer principios, preceptos, avisos, que lo condujeran a nuevas y distintas soluciones a los casos.

Los libros que nutrían al letrado no eran solo de materia jurídica pues su horizonte intelectual era mucho más extenso. Así agregaba Cabrera Núñez de Guzmán que "el abogado perfecto" debía ser muy erudito en la jurisprudencia, tener noticias de "todas las Ciencias y Artes", saber Historia y poseer elocuencia. También conocer "la política y razón de Estado". Concluía, en fin que "la Abogacía es compendio de todas ciencias" ${ }^{34}$

En apretada síntesis, vemos aquí estas útiles recomendaciones que se daban para que el principiante se manejara dentro del laberinto de la jurisprudencia casuista, siguiendo al hilo el sentido que se inculcaba en aquellos breves escritos de nivel universitario sobre "Modos de pasar en Derecho" que circulaban en la época. Así vemos como la lectura, manejo y entendimiento de los libros era asunto principal de las aulas que continuaba naturalmente impregnando el posterior itinerario profesional del jurista.

El libro era así auxiliar principal del jurista en la tarea cotidiana de abogar, proponer, asesorar, criticar, reformar y elaborar nueva doctrina. En el siglo XVII, algunos equiparaban los libros del letrado a las armas del caballero. Un autor precisaba que las armas eran el corazón y las letras el cerebro de "este

33 Véase Ismael Sánchez Bella, "Los comentarios a las Leyes de Indias", en Anuario de Historia del Derecho Español, vol. 24, Madrid, 1954, pp. 437-438.

34 Melchor Cabrera Núñez de Guzmán, Idea de un abogado perfecto, reducida a práctica..., Madrid, 1683, pp. 2-4, 160-165, 211-216 especialmente. 
cuerpo místico y político del Reino”, que no podía vivir ni conservarse sin ellos". 35

Esta estrecha relación del jurista con el libro, se había acentuado en los primeros tiempos modernos con la difusión de las letras alcanzada por la imprenta y la aparición de nuevas corrientes intelectuales. El saber libresco permitió el trasplante del Derecho común y castellano al Nuevo Mundo. A ello se sumó la nueva literatura generada por los juristas indianos. A la impresión de los relevantes cuerpos legales del derecho romano, canónico y castellano-indiano se unieron las obras jurisprudenciales y otros tratados teóricos y prácticos junto con numerosos escritos jurídicos y judiciales menores. En apoyo a la labor de los letrados acudían, por su continua conexión en cuestiones que les eran comunes, los tratados de teología, teología moral, política, economía, filosofía e historia, áreas todas ellas cercanas al interés intelectual del jurista. A su vez, los libros jurídicos atraían crecientemente a un mundo extendido de las artes y las letras, compuesto por eclesiásticos, literarios, eruditos y escritores varios, que podían integrar el grupo de los paraletrados y de los infraletrados, según los denomina Pelorson. ${ }^{36}$ A través de ellos se extendía a otros sectores sociales el léxico de los letrados, en géneros como la novela, el teatro, la copla y aun las canciones rústicas. ${ }^{37}$

La imagen literaria o pictórica del buen jurista estaba asociada a un conjunto numeroso y selecto de libros. Se solía presentar a los letrados civiles y canónicos hispanos rodeados de libros, en una clara alusión a que éstos constituían la más necesaria y decorosa compañía para enaltecer su figura. No existiendo por entonces bibliotecas públicas accesibles, era preciso que los letrados, y sobre todos los jueces superiores, poseyeran buenas bibliotecas de donde pudieran servirse para el desempeño de sus tareas.

Es cierto que los libros por sí solos no eran suficientes para dirigir el ánimo del juez hacia las soluciones adecuadas. Así Solórzano - una buena autoridad en la cuestión - decía hablando del proceder de los oidores que

35 Francisco Ugarte de Hermosa y Salcedo, Origen de los dos gobiernos divino y humano y formas de su ejercicio en lo temporal, Madrid, 1655, p. 316.

36 Pelorson, Los letrados juristas..., cit., p. 16.

37 Daisy Rípodas Ardanaz, "Popularidad de lo jurídico en los siglos coloniales. Un examen de la literatura de la Arquidiócesis de Charcas", en Revista de Historia de América, Instituto Panamericano de Geografía e Historia, México, núm. 101, 1986, pp. 37-64. 
tanto la falta como el exceso de saber libresco era contraproducente en la debida expedición de los negocios a su cargo.

Tiempo atrás Malagón Barceló puso en evidencia dos hechos que conviene recordar en cuanto a la circulación de la literatura jurídica. De una parte, la difusión que las obras de jurisprudencia española alcanzaron en los siglos XVI y XVII en Italia, Francia, Inglaterra y Polonia, junto con la presencia de profesores españoles en universidades de esos países y con la recepción en España de algunas doctrinas extranjeras. De otra parte, la expansión que aquellos cientos de obras tuvieron en México, según se puede verificar en inventarios de la Inquisición del siglo XVII. El aluvión de libros incluía además de la jurisprudencia española e indiana, obras de política, teología, moral, filosofía y economía. Este testimonio resulta de interés, en cuanto verifica la masiva llegada de libros para los juristas novohispanos, que se extendió a las demás provincias indianas. ${ }^{38}$

La historia del libro jurídico es área temática del Derecho indiano aún poco desarrollada. ${ }^{39}$ Merece preferente atención lo relativo a la edición, circulación, traducción y vigencia a través del tiempo de esas obras jurisprudenciales, no solo dentro de los espacios jurisdiccionales originarios sino también en otros territorios, donde se pueden detectar los itinerarios de una cultura jurídica compuesta de diversos circuitos y niveles de lectores. En este mismo sentido resultan de mucho interés los estudios sobre los libros jurídicos que integraron bibliotecas públicas o privadas de ministros reales, como los oidores de las audiencias, que marcaron a fuego ese sello de autoridad alcanzado por un escogido número de obras o libros jurisprudenciales. $^{40}$

38 Javier Malagón Barcelo, La literatura jurídica española del Siglo de Oro en la Nueva España. Notas para su estudio, México, 1959.

39 Víctor Tau Anzóategui, Nuevos horizontes en el estudio histórico del Derecho indiano, Buenos Aires, 1997, pp. 69-84. Me remito a esas paginas donde me propuse abordar, en apretada síntesis, varias cuestiones alrededor del antiguo libro jurídico con el objeto de dar sentido orgánico a los esfuerzos realizados hasta ahora y de incorporar nuevos criterios de análisis para potenciar esta área de labor, que tiene como eje a las obras jurisprudenciales como textos de autoridad, fijadores del Derecho provenientes de diversas fuentes jurídicas y literarias.

40 Para esta cuestión me remito a Daisy Rípodas Ardanaz, "Bibliotecas privadas de funcionarios de la Real Audiencia de Charcas" en Memoria del II Congreso Venezolano de Historia, Academia Nacional de la Historia, Caracas, 1975, t. II, pp. 499-555. 


\section{La Politica Indiana, modelo de obra jurisprudencial}

El tratamiento temático del libro jurídico indiano necesariamente debe culminar con la imagen de una obra en particular, que sirva para representar el género. En tal sentido, me ocuparé de la Política Indiana de Juan de Solórzano Pereira, que es, sin duda, la más importante obra jurisprudencial fijadora del ordenamiento indiano. Adelanto aquí sólo algunas ideas al respecto, que el lector podrá observar de modo particular, y a veces reiterativo, en varios estudios contenidos en el presente libro.

La obra de Solórzano se encuadra dentro de la literatura casuista, que permite observar ese mecanismo de argumentación aplicado a una realidad nueva, distinta y variada: el Nuevo Mundo o Novus Orbis. El autor decía que "entre los nombres que hasta hoy se han dado a nuestras Indias, ninguno hallo más convincente y significante de su grandeza” que ese mismo. Aunque el enfoque estaba centrado en el Perú - ámbito que él conocía - su mirada se extendía hacia las demás provincias, con ejemplos y situaciones extraídos de su larga experiencia en el despacho de los asuntos en el Consejo de Indias. La vigencia de la obra se extendió por más de un siglo y medio, con amplia circulación. Así en 1736 decía Ramiro Valenzuela, a cargo de una nueva edición: "es uno de los libros principales para el gobierno y decisión de las causas y negocios de las Indias".

En la Política Indiana se refleja, de manera cabal, el perfil del jurista que estamos tratando de esbozar, en donde se expresan y se perciben las posibilidades de avance y las limitaciones que tenía la acción del hombre de derecho como constructor del orden jurídico de ese tiempo. Solórzano fue un jurista comprometido con la delicada tarea de ocuparse de ese orden en las Indias, tanto por la vía legislativa como por la vía de la doctrina de autores, en el arco temporal central del siglo XVII. El Derecho indiano ya tenía para entonces suficiente desarrollo pero sus elementos estaban dispersos. Faltaba el jurista que trazara los criterios fundamentales de ese ordenamiento. No lo alcanzaron a realizar otros hombres de su tiempo y, en cambio, Solórzano lo cumplió acabadamente, prolongándose la autoridad de su pluma hasta los profundos cambios en la concepción jurídica del siglo XIX.

Un minucioso análisis sobre las fuentes librescas utilizadas en la elaboración de la Política Indiana permite a la investigadora Ana María Barrero sostener que dicha obra, junto con el libro predecesor De Indiarum Iure, "pueden ser considerados como un vehículo de transmisión de la literatura 
jurídica europea y en especial del derecho común al continente americano". Las citas de autores y obras en el texto de Solórzano abarcan una variedad que excede el área jurídica y alcanza a fuentes literarias de diverso carácter y autoridad, de índole sagrada, histórica, política, científica, etc. Dentro del campo jurídico es también muy amplia la mención que se hace de autoridades y doctrinas de distintas épocas, aunque naturalmente predominan la de los siglos XVI y XVII. Se suceden así las citas de juristas y escritores de los reinos hispanos, de Italia y otros países del derecho común, de distintas escuelas. Algunas de ellas provenían de textos de conocimiento directo por parte del autor, otras extraídas seguramente de los abundantes "repertorios de autoridades". Era el apoyo necesario a la argumentación desarrollada en una cuestión o a la exposición de una idea o principio rector. ${ }^{\mathbf{4 1}}$

La circulación de esta literatura jurídica no produjo solo una simple trasmisión unidireccional de autores y doctrinas del Ius commune hacia el Nuevo Mundo, ya que la aplicación local de esas teorías y lecturas fue variable según lugares y circunstancias. Es difícil precisar cómo realizó Solórzano su tarea sobre aquel aparato libresco que le servía de apoyo y también apreciar en qué medida aparecía la reflexión y creación propia derivadas de esas lecturas o de su vasta experiencia en la magistratura limeña. Lo que parece más evidente es que en diversas ocasiones debió acudir, fuera del núcleo conceptual del Ius commune, a la elaboración teórica para afirmar principios e instituciones del derecho indiano, cubriendo vacíos o reemplazando contenidos de aquella procedencia que no resultaban aplicables a la realidad del Nuevo Orbe.

Cabe también preguntarse, en punto a esta circulación de libros e ideas, cómo se leyó la Política Indiana dentro de la cultura europea del Ius commune y con qué resultados. Para esto contamos con un notable ejemplo, ofrecido por el profesor Ditlev Tamm, quien coloca a la obra de Solórzano en lugar relevante dentro de la literatura sobre derecho indiano de los siglos XVI y XVII, conocida en el norte de Europa. De modo particular, le asigna el papel de trasmisor del concepto político de unidad imperial de la Monarquía española, influyendo en quienes, hacia 1660, constituyeron como gobierno absoluto a la Monarquía compuesta de Dinamarca y Noruega, que contaba

41 Ana María Barrero García, "La literatura jurídica del barroco europeo a través de la obra de Solórzano Pereira", en Revista Chilena de Historia del Derecho, núm. 15, Santiago, 1989, pp. 65-85. 
con varias dependencias de ultramar. Por lo demás, es curiosa la existencia de ejemplares de distintas ediciones de la Política Indiana y de otros autores de derecho indiano en la Biblioteca Real de Copenhague. ${ }^{42}$ Este aporte levanta una punta del velo que mantiene oculta la presencia de juristas del Nuevo Mundo y sus obras en países europeos no españoles.

Finalmente deseo apuntar mi propia observación. Cuando años atrás estaba empeñado en una línea de investigación que buscaba penetrar y comprender la mentalidad casuista de aquella época y sus mecanismos de argumentación e invocación, utilicé para este ejercicio la Política Indiana. A medida que avanzaba en su lectura fui descubriendo mecanismos, enfoques e ideas que superaron ampliamente mis expectativas ofreciéndome un panorama esclarecedor del tema principal y suscitando cuestiones e interrogantes colaterales. Así observé como Solórzano trataba las diversas cuestiones, a veces dando prioridad a un enfoque conceptual, otras presentándola en torno a un caso, señalando las distintas opiniones, pronunciándose a veces por una de ellas con decisión, o por otra como más probable, y a veces dejando pendiente la solución. Las notas y apuntes acumulados como cosecha natural de tan provechosa lectura me permitieron desarrollar o enriquecer algunos de mis posteriores estudios.

\section{Experiencia y prudencia en el jurista}

El saber jurisprudencial adquirido en las aulas y en los libros específicos no era suficiente. Para alcanzar su plenitud el jurista necesitaba contar con ciertos atributos - experiencia y prudencia - y otros saberes humanos que si bien ya eran exigidos al letrado castellano, con más énfasis se indicaban para quienes se trasladaban al Nuevo Mundo. Algunos ejemplos concretos, especialmente de los tiempos iniciales de la colonización pueden ser útiles para introducirnos en el planteamiento de la cuestión.

La experiencia, como necesario atributo del jurista, se consideraba - más en los siglos XVI y XVII - como un elemento imprescindible en la decisión de un asunto público. Sobre todo se hacia evidente entre los juristas castellanos que al salir de sus tierras observaban otras realidades en los diversos

42 Ditlev Tамm, Clásicos del derecho indiano en Dinamarca. Un estudio sobre el derecho indiano de la época entre 1550 y 1650. Editorial Académica Española, Saarbrücken, 2012, pp. 6-27. 
territorios de la Monarquía donde desempeñaban funciones al servicio del rey. ${ }^{43}$

El gran toque de atención lo había dado el virrey Antonio de Mendoza en un informe al rey sobre la situación de México en 1550. En tono vigoroso exponía el irreparable mal que causaba la falta de experiencia en ministros y magistrados: "Provee S. M. a mi y otros como yo por virreyes y gobernadores, siendo nuevos en los cargos y no teniendo experiencia; envía oidores que allá no se proveerán por alcaldes mayores, y fiale un mundo nuevo sin ninguna orden ni razón ni cosa que parezca a lo de allá, ¿qué espera S. M. que ha de suceder a dos mil leguas de donde está sino dar con todo en el suelo y que se acabe haciendo experiencias antes que lo entienda?". ${ }^{44}$

Experiencia sobre las distintas comarcas, experiencia en los negocios y pleitos eran reclamos generalizados en los siglos XVI y XVII para completar el conocimiento teórico del letrado. ${ }^{45}$ "No basta - decía Cabrera - la más aguda especulación del Derecho para la inteligencia y determinación de los pleitos y negocios: es necesario haber reducido a experiencias y demostraciones prácticas, las doctrinas, conclusiones y reglas que se tratan y disputan en la Universidad". 46 La carencia de experiencia era considerada una de las causas de fracaso de los letrados en el gobierno. Otro autor del seiscientos entendía por sabios y doctos en derecho "a aquellos a quien la lección de libros, y la experiencia de negocios, y noticia de pleitos, les han dado autoridad para poder hablar y decir su parecer para el acierto de los casos y ocasiones ocurrentes.... ${ }^{47}$

Mucha era la atención que se prestaba al obrar humano en el gobierno y justicia de una sociedad regida por un orden jurídico, basado en una concepción casuista, en donde el gobernante y el magistrado gozaban de un amplio margen de discrecionalidad. La presencia decisiva de esa acción

43 Sobre esto, véase Pelorson, Los letrados juristas..., cit., pp. 375-376.

44 Lewis Hanke, Los virreyes españoles en América durante el gobierno de la Casa de Austria, México, t. I. BAE, Madrid, 1976-1978, pp. 57-58.

45 José M. Mariluz Urquijo, "El saber profesional de los agentes de la administración pública en Indias", en Estructuras, gobierno y agentes de administración en la América Española. Siglos XVI, XVII y XVIII (VI Congreso del Instituto Internacional de Historia del Derecho Indiano), Valladolid, 1984, p. 252.

46 Cabrera Núñez de Guzmán, Idea de un abogado..., cit., p. 2.

47 Pedro de Reina Maldonado, Norte claro del perfecto prelado, en su pastoral gobierno, Madrid, 1653, t. 1, p. 326. 
humana era clave en una sociedad dinámica, en donde la variedad de casos y ocasiones exigían la adecuación de las normas a las situaciones dadas. Solo a través de determinadas virtudes morales se podía alcanzar que ese obrar fuese positivo. En este sentido es que Bermúdez de Pedraza decía que "los juristas son verdaderos religiosos, no en el hábito, sino en el ánimo, usando de equidad y justicia". ${ }^{48}$

Aunque era una situación generalizada en el orbe hispano, la mayor valoración hacia ese obrar humano, con fuerza incluso superior a las mismas leyes, se daba en las Indias, principalmente en el siglo XVI. Así se puede recordar la conocida queja del licenciado Diego Tellez enviada al rey, sobre la conducta de los oidores de la Audiencia novohispana, en la que intentaba que las altas autoridades comprendieran que una tierra nueva y lejana requería otra gobernación a la existente en los reinos peninsulares y que los oidores que se designasen "sean de edad perfecta, honestos, temerosos de Dios y de sus conciencias tengan siempre vuestra alteza delante los ojos”. ${ }^{49}$

Era aún más patético el reclamo, que en el mismo sentido, hacían en 1550 otros dos experimentados observadores de la realidad americana. El virrey Antonio de Mendoza consideraba que en vez de expedir provisiones y órdenes contradictorias y mutables, todo se remediaba "con solo proveer personas calificadas que tengan en razón y justicia la tierra" ${ }^{50}$ En coincidencia Andrés de Tapia, uno de los primeros conquistadores de Nueva España, encarecía que el rey y el Consejo de Indias enviasen a las Indias personas de calidad, en las que "deje a su arbitrio que haga y deshaga leyes, sino presto acabará las Indias de Nueva España y Perú como se han acabado las demás" ${ }^{51}$ Es bien cierto que estos reclamos - casi angustiosos - se hacían en situación de emergencia, en momentos en que la colonización se encontraba en una de sus más tempranas y profundas crisis, pero los testimonios - aun con intensa carga de emotividad - son reveladores del aprecio concedido al buen obrar humano por sobre las mismas leyes.

En fin, la constante preocupación por este aspecto también quedó registrada en las estrofas de Juan de Castellanos, que atribuía los gobiernos

48 Bermúdez de Pedraza, Arte legal..., cit., p. 32.

49 Francisco Paso y Troncoso (ed.), Epistolario de Nueva España 1505-1818, México, 1939-1942, t. XIV, pp. 155-156.

50 Hanke, Los virreyes españoles..., México, I, cit., pp. 57-58.

51 Paso y Troncoso, Epistolario de Nueva España..., cit., t. VI, p. 8. 
desacertados de los letrados, además de la falta de experiencia, a la "gran soltura de conciencia”. De ahí que una persistente literatura moral y política durante el siglo XVII y el mismo XVIII, se ocupara de inculcar en ministros, jueces y abogados hábitos de rectitud y moralidad en el desempeño de los oficios. Así la pluma crítica de Juan Francisco de Castro sentenciaba que no había empleo en que "más se necesite rectitud de intención, verdad, fidelidad, consumada prudencia y pureza de costumbres". ${ }^{52}$ Literatura que seguramente logró morigerar hábitos, atajar abusos y contribuir a una mejor preparación moral, pero que en su reiteración misma testimonia también como se infringían esos preceptos.

La prudencia era un atributo que condensaba otros, dando lugar a un particular desarrollo tanto en las esferas del Derecho, como en la Política o la Moral. No en balde aquella denominación de jurisprudencia o jurisprudente. No es posible componer la imagen del jurista sin referirse a ella. Los humanistas - dice Piano Mortari - vieron en la prudencia la principal de las virtudes civiles. Así la conducta moral, la acción política y la decisión jurídica eran el fruto esperado de la prudencia. ${ }^{53}$ Juan Luis Vives consideraba que era "la cosa más necesaria en todas las circunstancias de la vida" y se preguntaba: "¿quién que carezca de gran prudencia podrá ver o definir la equidad de las cosas? ¿qué podremos decir entonces de muchos que son a la vez expertísimos en derecho y absolutamente carentes de prudencia....?" ${ }^{54}$ Si bien la inspiración venía del pensamiento clásico, estaba fuertemente enraizada en la concepción del mundo que tenía el jurista medieval. La línea aristotélica tomista la proyectaba claramente sobre la época.

Según se pensaba, la ciencia jurídica no se agotaba en la teoría. Era tan solo un presupuesto para el obrar iluminado e informado en cada caso. De ahí que los vocablos prudentia y prudentia iuris sirvieran entonces para definir el saber del jurista. La prudencia - recuerda Piano Mortari - era la doctrina con la que el jurista indicaba si el hecho era lícito o ilícito. En esto la preparación técnica se unía a un fino sentido de lo concreto. De ahí que

52 Juan Francisco de Castro, Discursos críticos sobre las leyes y sus interpretes..., libro III, discurso VI (1765), ed. 1829, t. I, pp. 263-267.

53 Vicenzo Piano Mortari, "Pensieri di Alciato sulla Giurisprudenza" en ídem, Diritto. Logica. Metodo nel secolo XVI, Napoli, 1978, pp. 354-356.

54 Juan Luis Vives, Causas de la decadencia de las artes (1531), Edición, Buenos Aires, 1948, p. 418.

$22 \mid \quad$ Introducción 
el prudente fuese considerado, tanto en la antigüedad clásica, como en el medievo y entre los humanistas - tal el caso de Alciato, objeto específico de estudio de aquel autor - como el hombre de acción capaz de adaptar los principios universales del saber a la situación de la vida práctica, que es individual y particular. Así aparecía como atributo necesario al político, al moralista y al jurisconsulto, ya que en estas tres esferas, sujetas a esa reflexión y a la experiencia, las soluciones quedaban supeditadas a los casos tal como se fuesen presentando, ya que no había reglas prefijadas que establecieran aquellas de modo absoluto. ${ }^{55}$

\section{El cambio de escenario}

En estas páginas aparece registrada la fuerte presencia del jurista en el escenario del saber, donde convivía con otros autores y pensadores, como teólogos, filósofos, políticos, literatos y eruditos varios, etc. El juego de esos diversos saberes integraban un universo intelectual con estrechos contactos entre las leyes, los cánones, la teología dogmática y la moral, la política y la economía, a menudo superpuestas, complementarias y a veces en difícil pugna. Esto daba una enorme riqueza al campo del pensamiento y explica el papel que desempeñaba el hombre de derecho como agente activo en el tejido social de su tiempo, especialmente en el novedoso ámbito del Nuevo Mundo.

El perfil trazado de este jurista castellano-indiano se fue desvaneciendo cuando el escenario del saber se modificó en consonancia con el gran movimiento de transformación general de la sociedad occidental ocurrido hacia fines del siglo XVIII, que se extendió a lo largo de las décadas siguientes. Ya era visible el avance de un modelo distinto de concebir el Derecho. Se estaba produciendo, en palabras de Santos M. Coronas, una evolución "desde el antiguo orden doctrinal, judicial y consuetudinario del ius commune hasta la nueva filosofía de la razón" ${ }^{56}$

Bajo el estímulo de la filosofía, la economía y la política, se fueron estableciendo nuevos saberes formativos de los juristas con la pretensión de

55 Sobre esto, véase también Roberto I. Peña, Los sistemas jurídicos en la enseñanza del Derecho en la Universidad de Córdoba (1614-1807), Córdoba, 1986, pp. 142 y ss.

56 Santos M. Coronas, "Jovellanos y el método jurídico", en Jovellanos, el valor de la razón (1811-2011). Edición coordinada por Ignacio Fernández Sarasola y otros autores, Gijón, 2011, p. 323. 
alcanzar la uniformidad y certeza del Derecho mediante la construcción de nuevas reglas y principios que lo sustentaran. Bajo la égida de una fuerte teorización política, el Estado fue reconocido como agente productor exclusivo de dichas reglas. Se pudo así establecer un orden legal asentado principalmente sobre las constituciones y códigos, seguido de una importante construcción iusteórica de juristas europeos de la época que fue recibida y adoptada dentro del orden hispano y particularmente en los nuevos Estados que surgieron en la América española al producirse la desmembración de la Monarquía.

La nueva legalidad requería de un tipo de jurista distinto al actuante en los siglos precedentes. En estas condiciones quedó desplazada una parte sustancial de la literatura jurídica existente y fueron condenados al olvido los grandes juristas del derecho castellano-indiano que habían mantenido una larga vigencia. Con todo, ese cambio no fue súbito ni total. Mediante un constante ejercicio de revalorización pervivieron en el tránsito del orden tradicional a la legalidad contemporánea diversos rasgos del antiguo mundo de los letrados. 


\section{La idea de Derecho en la colonización española en América*}

Sumario: 1. La plasticidad del Derecho trasplantado en las Indias - 2. El Derecho y la Religión - 3. El Derecho natural y el orden positivo - 4. La Moral y el Derecho - 5. El Derecho y la Justicia - 6. Los juristas

\section{La plasticidad del Derecho trasplantado en las Indias}

La expansión de la civilización europea y cristiana - a través de Castilla hacia tierras nuevas a fines del siglo XV fue portadora de una concepción del Derecho - consolidada en los tiempos medievales - que debió abrirse ante los vastos horizontes descubiertos y ante las situaciones concretas, nuevas y plurales, que presentaba el desenvolvimiento de la conquista y colonización de América.

El Derecho no es un elemento técnico aislado ni ajeno al mundo de la cultura, ni al desarrollo de una civilización. Es uno de sus factores dinámicos. Sus conexiones con el ámbito social, con las corrientes de pensamiento, con la mentalidad y aspiraciones colectivas, deben ser punto de referencia permanente para quien procura conocer tanto el Derecho como la Sociedad. Con la expansión española de los tiempos modernos, el Derecho acompañó ese singular espíritu de empresa material y espiritual, tratando de regular la organización social de los territorios y gentes incorporados a la Monarquía.

El Derecho trasplantado siguió en buena parte la fisonomía de los procesos de conquista y colonización, adaptándose a los variados requerimientos geográficos y humanos de las distintas regiones y dando tempranas muestras de su especialidad y novedad. Se nos aparece así como amplio, variado y mutable, esquivo a que su espíritu quedase aprisionado en un formal cuerpo legislativo o en un único modo de creación jurídica.

* Publicado, en lengua alemana, en Hans Thomas (Hg.), Amerika, eine Hoffnung, zwei Visionen. Lindenthal-Institut, Köln, 1991, pp. 95-124. El texto en castellano apareció posteriormente en Fundación. Política y Letras, núm. 5, Buenos Aires, 1995, pp. 76-83. 
El Derecho de estas Indias Occidentales y Orientales fue así modelándose de manera casuista durante los siglos XVI y XVII, sobre la sólida base de los Derechos romano y canónico y de la cultura jurídica europea, que tuvo por entonces en el Siglo de Oro castellano su momento de esplendor. En su compleja composición se reunían elementos procedentes del rancio Derecho trasplantado por Castilla con las nuevas soluciones jurídicas reclamadas, entre las cuales se incorporaban los propios usos y costumbres de los aborígenes que quedaron, voluntaria e involuntariamente, integrados en el proceso de la colonización.

\section{El Derecho y la Religión}

Entre los hispanos el Derecho era considerado como uno de los elementos de ordenación de la vida social, junto a la Religión y a la Moral. Cada uno tenía su propio ámbito y esa diferencia estaba afianzada por disciplinas que cultivaban los respectivos conocimientos. De tal modo lo vemos planteado por teólogos, moralistas, juristas y políticos. Pero al mismo tiempo se aprecia un enlace entre ellas. No se concebía así el Derecho en función ordenadora, sin la Religión y la Moral. Era una arraigada y difundida creencia social, cuya verdadera fuerza puede apreciarse históricamente en los siglos XVIII y XIX cuando se produjo el avance de las corrientes secularizadoras.

En el mundo hispano hubo estímulos especiales para que ese enlace se mantuviese durante la colonización americana. La Religión, pilar fundamental de la vida española, tuvo presencia política en la empresa contra los moros, en la evangelización de América, y en las luchas europeas de los siglos XVI y XVII. La Moral recibió, a partir del Quinientos, fuertes estímulos para su desenvolvimiento con la Reforma protestante y con los renovados problemas de conciencia surgidos en las Indias.

La influencia de la Religión sobre el Derecho civil se remonta a los tiempos en que el cristianismo insufló sus principios en el ordenamiento romano. La Monarquía española era confesional. En 1505 se estableció que sólo las personas bautizadas tenían capacidad jurídica. Esta tendencia se acentuó con su actitud decisiva en apoyo de la Iglesia de Roma y con la actividad apostólica entre los aborígenes americanos.

Asimismo se dio un influjo de aquel Derecho civil sobre la constitución normativa de la Iglesia, al adoptar ésta la técnica jurídica de los romanos para elaborar su propio Derecho, distinguiendo así lo normativo de lo dogmático. 
De tal modo, en el medioevo, el Derecho se componía de dos brazos, el civil y el canónico. Esta unión persistió en el mundo hispano de los tiempos modernos, enfrentando la ruptura de la Reforma protestante. No permaneció empero inmutable. Al abrirse en América un nuevo proceso de evangelización - que algunos compararon con la labor de los primeros apóstoles de la Cristiandad -, la experiencia inicial dejó abundante enseñanza para introducir nuevas normas dentro de un ordenamiento que carecía por entonces de sensibilidad misional. Las reglas dadas en los concilios provinciales de México y Lima durante el siglo XVI y en los sínodos locales, junto con costumbres y doctrinas particulares, constituyeron la base de un Derecho canónico particular, desarrollado fuera del poder centralizado de la Iglesia de Roma. Este desenvolvimiento tuvo más tarde influjo universal cuando en el siglo XIX se desplegó una intensa labor de evangelización en otros continentes.

A principios del siglo XVII el jesuita Francisco Suárez decía que el teólogo no podía agotar la materia propia de su disciplina sino se detenía a estudiar las leyes. La Teología era entones considerada como la madre de todas las ciencias, y los principios generales del Derecho, uno de sus objetivos preferidos. De ahí que los teólogos españoles de los siglos XVI y XVII - inmersos en una renovación humanista - hicieron una contribución teórica al desenvolvimiento del Derecho de tal significado que hoy algunos de ellos - Vitoria, Soto, Suárez - son considerados como precursores o iniciadores de las nuevas direcciones que el Derecho adquirió en la Edad Moderna, incluso del mismo proceso de secularización. Fruto principal de aquella elaboración es el Derecho natural moderno.

\section{El Derecho natural y el orden positivo}

El Derecho se concebía como derivado de un Dios creador. Sobre aquel imperaba el Derecho natural, conocido por medio de la razón. No podía reducirse a reglas fijas ni era inmutable, salvo en algunos de sus principios. Para completarlo estaba el Derecho positivo dado por los hombres, cuyos enunciados no debían ser contrarios a aquél.

Durante la Edad Media se solía identificar el ordenamiento romano-canónico con la razón natural, pero ya a fines de aquella época y sobre todo a partir del siglo XVI el Derecho natural empezó a convertirse en una disciplina que ampliaba el cauce racional en el que se desenvolvía la jurispruden- 
cia. En el mundo hispano se hizo notorio en el pensamiento de los teólogos. Al ocuparse de los problemas originados por el descubrimiento de América revisaron y actualizaron los principios expuestos por Tomás de Aquino. Se estableció así que dicho Derecho natural regía para todos los hombres, fuesen o no cristianos, lo que Vitoria aplicó a los aborígenes. Su influjo sobre la legislación indiana no se hizo esperar.

El Derecho natural estuvo desde entonces presente, con mayor o menor intensidad, en la labor intelectual de teólogos, filósofos, juristas y políticos, convirtiéndose en disciplina teológica, filosófica o jurídica según fuesen las épocas y países. Fuera del mundo hispánico, su desenvolvimiento alcanzó diferentes matices en Alemania, Francia o Italia. A partir del siglo XVIII actuó como agente activo en la secularización, sistematización y reforma del ordenamiento jurídico. Su estudio en las aulas empezó a considerarse indispensable. El Derecho natural aparecía colocado por encima de todo orden positivo, histórico o actual.

Entre los autores hispanos del XVIII tendió a matizarse un Derecho natural enteramente abstracto y secular. El empirismo y la religiosidad que animaban el alma española, llevó a los juristas a preferir concepciones de ese Derecho natural más afines con dicha peculiaridad, como la del francés Jean Domat. Las elaboraciones iusnaturalistas hispanas de entonces - sin duda menos originales que las del siglo XVI - no han sido hasta ahora examinadas teniendo en cuenta este punto de vista. La idea de un Derecho natural, con las alteraciones insinuadas, se mantuvo hasta el siglo XIX. De tal modo, la noción del Derecho dominante en toda la época que enfocamos se asentaba sobre una concepción metafísica, que superaba la estricta legalidad y que derivaba mediata o inmediatamente de Dios, por medio de la razón humana.

Partiendo de esta base, los juristas concebían el Derecho en estrecha relación con la realidad, materializado en normas y entendido como modo de realizar la justicia concreta. Procurábase dar solución adecuada a los casos tal como se presentaban, sin desplegar teorías ni aspirar a la formación de un sistema normativo abarcador. Era, mutatis mutandis, la técnica de los juristas de la Roma clásica y del bajomedievo. Esta orientación quedó acentuada en el Derecho indiano de los siglos XVI y XVII, ante las situaciones concretas nuevas no previstas en anteriores ordenamientos ni en las obras jurisprudenciales del Derecho común. Las normas se aplicaban selectivamente de acuerdo a la persona, lugar, tiempo y demás circunstancias en la resolución de los casos. 
Sin que esta peculiaridad se modificase súbitamente, ya desde mediados del Seiscientos - junto con los intentos de consolidar el Derecho indiano empezaron a percibirse ciertos esfuerzos sistemáticos, especialmente en la didáctica jurídica. En el siglo XVIII, bajo el influjo del racionalismo, el "ideal del sistema” empezó a proclamarse más abiertamente. El desenvolvimiento ya referido del Derecho natural impulsó esta orientación, cuyo fruto más preciado se alcanzó con la Codificación.

\section{La Moral y el Derecho}

La Moral como elemento ordenador de la sociedad mantuvo estrechas relaciones con el Derecho, particularmente en los siglos XVI y XVII. Un efecto de arrastre hizo todavía poderosa su presencia en la centuria siguiente. De un lado impregnaba ciertas soluciones jurídicas, como aun hoy lo hace en los actuales ordenamientos. De otro regulaba directamente aspectos no tratados por el Derecho. De ahí que algunos libros de Moral de la época puedan fácilmente catalogarse como jurídicos por el material de esta procedencia recogido y expuesto. Los juristas, renuentes a alejarse de su propia tradición literaria, no dejaban empero de acudir a los moralistas - o a sus doctrinas cuando los problemas planteados en su esfera escapaban a una mera regulación de la conducta externa y afectaban al fuero de conciencia.

La Moral, como disciplina dentro de la Teología, alcanzó su mayor desenvolvimiento en el Renacimiento. Al acentuar la doctrina católica - frente a la tesis de Lutero - la importancia de la voluntad del hombre y de sus obras para alcanzar la eterna bienaventuranza, se hizo necesario una constante dirección de los problemas de conciencia que afectaban al cristiano, sobre todo al tratarse de los casos más frecuentes que surgieron al producirse la expansión española en el Nuevo Mundo. Surgió asi de modo relevante la figura del moralista, por lo general un religioso de reconocido saber y buen juicio. A él se le solicitaba el consejo para que, conforme al caso concreto que se le presentaba, determinase la licitud del acto y la conducta a seguir, tanto fuesen negocios particulares como públicos, ya en forma individual o colectiva.

Las soluciones dadas por el moralista tenían una validez limitada al caso propuesto. Aun así servían de apoyo en la determinación de situaciones análogas en el futuro. De ahí fue surgiendo un género literario, ya reuniéndose colecciones de casos y resoluciones, ya procurando establecer algunas 
reglas generales inducidas de esta casuística. Destácase la estrecha vinculación que guardaban problema y solución con la normativa jurídica. Entre los más frecuentes "casos morales" que se presentaban en las Indias pueden mencionarse los relativos a la usura, la celebración de contratos, el cumplimiento de determinadas obligaciones, el hallazgo de tesoros escondidos, la pertenencia de los frutos, la restitución a los indios por robos, muertes o abusos de los encomenderos, etc. A través de estos casos se fueron estableciendo, sino soluciones concretas, criterios orientadores para el futuro. Al estudiar la compleja vida religiosa española de los siglos XVI y XVII, Julio Caro Baroja señala la abundancia y notoriedad de esta literatura moral, que el estudioso moderno aun no ha estimado en plenitud. Al avanzar el Setecientos decayó ese ostensible vigor.

Aunque el teólogo, el jurista - civilista y canonista - y el moralista tuviesen su propio campo de acción intelectual y práctico, existía un entramado de esas áreas en su común función de ordenar la vida social. El conocimiento del Derecho no se agotaba pues en su ámbito específico, sino que, cuando correspondía, atendía también a la doctrina de los teólogos y a la atildada casuística de los moralistas.

\section{El Derecho y la Justicia}

La idea de Derecho aparecía enlazada con otra noción propia del mundo moral y material. La justicia, voz divina y humana, de esperanza y frustración, concepto ambiguo que anida en el espíritu del hombre, tuvo vigorosa presencia en la sociedad hispana de la época. Desde el mundo grecorromano hasta el siglo XVIII se consideraba que la justicia era el fundamento del orden social, era "como fuente donde manaron todos los derechos", según decían las Partidas, el código alfonsino del siglo XIII.

Convergían en esta noción perfiles doctrinales, virtuosos, intimistas, no siempre exteriorizados a través de los actos concretos gubernativos y judiciales. La definición aristotélico - tomista que la consideraba como el "hábito según el cual alguien da a cada uno su derecho con constante y perpetua voluntad", distinguía entre la justicia general, ordenada al bien común, y la justicia particular, referida a otro hombre. Esta última comprendía la justicia distributiva que regía la relación de la comunidad con el individuo según la regla de la proporcionalidad, y la conmutativa, que regía las relaciones entre individuos según la regla de la igualdad. 
Un escritor de mediados del Seiscientos decía que "la justicia no ha de estar en las paredes y puertas fija, sino en el ánimo y desvelo". Era considerada como virtud, por medio de la cual - según las Partidas - "se mantiene el mundo, haciendo vivir a cada uno en paz, según su estado, a sabor de si, y teniéndose por abondado de lo que ha”. Las letras y las artes de la época la peraltaban sobre las demás virtudes. La noción de justicia - simbólicamente encarnada en el rey - se materializaba cotidianamente en la que administraban jueces y tribunales. Acudían a solicitarla poderosos y pobres, españoles e indios. Era el modesto reflejo de la justicia divina - la justicia suprema se identificaba con Dios -, representada frecuentemente en los pórticos de las iglesias románicas y en las escenas del "Juicio Final". Para jueces y abogados, según Prodi, la justicia implicaba una carga de conciencia, que no exigía la fundamentación de las sentencias.

Desde los tiempos bajomedievales se fue imponiendo una idea de justicia surgida de las pruebas aportadas en un proceso judicial, decidido conforme al saber de los juristas. Cuando en las disposiciones reales dirigidas a los tribunales residentes en América se usaba la expresión "se haga justicia", la intención era incitar a que se resolviese la cuestión planteada conforme a ese cauce procesal. La justicia no se entendía como la mera aplicación de un precepto legal a una situación planteada, sino como la solución adecuada del caso, apoyada en un amplio y variado aparato normativo integrado por leyes, costumbres, obras jurisprudenciales, prácticas, etc. Se admitía el arbitrio del juez en la búsqueda de la equidad. De esta idea a la concreta realidad, el camino estaba lleno de escollos... La insatisfacción o el desencanto por esta justicia administrada por los hombres de toga abría rumbos a la sátira, expresada a través del teatro, la literatura y el refranero popular. Con frecuencia se solía mostrar - hasta de forma irrespetuosa - una justicia trascendente, concebida como valor intimista.

\section{Los juristas}

Los comienzos de la colonización española muestran una época en la cual los juristas, formando un grupo relevante, se encontraban en ascenso dentro de la sociedad estamental. Tal como lo ha estudiado Maravall, en los últimos siglos de la Edad Media española, aquéllos como poseedores de un saber especial empezaron a ejercer un creciente influjo sobre la sociedad, participando activamente en el poder, mediante la ocupación de plazas en consejos 
y tribunales reales y eclesiásticos, y el desempeño de otros oficios, además del ejercicio del foro, la cátedra y la actividad literaria. Sobre todo desde el reinado de los Reyes Católicos, se convirtió en la profesión que ofrecía mejores posibilidades de promoción económica y social. A principios del siglo XVII, Covarrubias en su Tesoro de la Lengua testimoniaba este avance social irresistible al expresar que los juristas se habían alzado con el nombre de "letrados", en perjuicio de los que profesaban letras.

Malagón Barceló ha dado a uno de sus estudios el expresivo título de "Una colonización de gentes de leyes", destacando el papel que los hombres de toga desempeñaron en América. Su presencia se advierte en cada paso adelante de la conquista y asentamiento, en la fundación de las ciudades, en los pareceres dados a los gobernantes, en la redacción de los documentos y normas, en la administración de justicia. En suma, en la articulación de la burocracia que sustentaba el "aparato estatal" de la Monarquía.

Sin embargo, el desdén hacía los letrados no estuvo ausente. Su misma preponderancia preparó la atmósfera para esa postura. Los abusos que se les atribuían -muchas veces con razón - llevaron también a muestras de recelo cuando no de repulsa directa, hacia quienes pretendían afincarse en los pequeños núcleos urbanos para ejercer la abogacía. Consideraban que su presencia estimulaba rencillas y pleitos entre los vecinos. América, tierra de utopías, albergaba acaso la utopia de un Derecho sin abogados.

El avance de los juristas en la sociedad hispana del Renacimiento guarda relación con el apogeo que los estudios de jurisprudencia tenían en las universidades castellanas del siglo XVI. Aquellos fueron mayoría en esas universidades. Los graduados de Salamanca, Valladolid y, en menor medida, Alcalá de Henares eran quienes más frecuentemente ocupaban plazas en el gobierno y la justicia de la inmensa Monarquía.

El modelo salmantino se trasladó tempranamente al Nuevo Mundo, donde en 1551 se establecieron universidades en Lima y México. También aquí los juristas predominaron. Teología, jurisprudencia y medicina eran los saberes superiores. El desenvolvimiento universitario indiano fue sostenido hasta el fin de la colonización. De los 32 intentos fundacionales, siete corresponden al siglo XVI, trece al XVII y doce al XVIII hasta la emancipación. Como ocurría en Castilla, en la sociedad americana los letrados disfrutaban de una buena posición. Sus graduados alcanzaron plazas en el gobierno y la administración de justicia locales. El criollismo tuvo en ellos prominentes defensores. 
La instrucción jurídica impartida en ambos mundos era análoga. El Derecho civil se estudiaba sobre todo en el Digesto y el Código, el canónico en el Decreto y las Decretales. Estos textos clásicos, junto con sus glosas y comentarios constituían el eje de la enseñanza. Durante la época la unión entre ambos Derechos no sufrió rupturas, como en la Europa protestante. A un mayor acercamiento con la práctica acudió las Partidas, espejo del saber antiguo y romano. En la segunda mitad del XVIII se percibe mayor interés por acentuar el estudio del Derecho real, castellano e indiano, y por introducir como disciplina nueva el Derecho natural.

El saber de los juristas no fue enteramente cerrado. Sus vocablos y giros enriquecieron el habla popular. Sus normas llegaron a conocimiento de los distintos estratos de la sociedad a través de disposiciones reales o locales que se leían y fijaban en lugares públicos. La misma justicia impartida por las audiencias fue -según revelan algunos recientes muestreos - atractiva para los indígenas y para los pobres y desvalidos, pues encontraron en dicho tribunal letrado, más amparo que en los jueces legos.

Al producirse a principios del siglo XIX la desmembración de la Monarquía Española y el surgimiento de los nuevos Estados hispanoamericanos, quedó esa sólida base jurídica, sobre la cual se empezó a tejer la nueva trama exigida por las transformaciones del mundo occidental del siglo XIX. En este nuevo tiempo, América estuvo en condiciones de recibir selectivamente el impulso renovador de la cultura jurídica de los principales países europeos. 



\section{II ¿Humanismo Jurídico en el Mundo Hispánico? A propósito de unas reflexiones de Helmut Coing**}

Sumario: 1. La exposición de Coing - 2. Significado de la propuesta - 3. Sobre la literatura jurídica hispana

\section{La exposición de Coing}

Es tarea de los historiadores revisar constantemente las construcciones intelectuales legadas por anteriores estudiosos, incluso aquellas que tienen la apariencia de ser, por su solidez, casi definitivas. Esa revisión es el resultado natural de una incesante labor monográfica y también de oportunos escritos programáticos que suelen plantear dudas o interrogantes, deslizar hipótesis e insinuar nuevos rumbos en la investigación.

En esta categoría de escritos cabe ubicar a una sugerente disertación del profesor Helmut Coing, pronunciada en Murcia en 1985 y publicada en castellano bajo el título La contribución de las naciones europeas al Derecho común. ${ }^{1}$ Con su reconocida profundidad y claridad expositiva, Coing plantea sucintamente en esta conferencia la necesidad de rectificar algunos aspectos de la imagen hoy dominante acerca del desarrollo de la ciencia jurídica en Europa durante los siglos XVI a XVIII. Sostiene que es conveniente atender, entre otros asuntos, al mundo hispánico, que ha quedado marginado en la consideración del historiador europeo. Este es precisamente el perfil que me interesa destacar en estas páginas, colocándolo en directa vinculación con la presencia determinante que pudo tener el humanismo jurídico en ese ámbito, asunto hasta hoy no indagado suficientemente. ${ }^{2}$ De nuestro particular

* Publicado en Anales de la Universidad de Chile. Estudios en honor de Alamiro de Ávila Martel, $5^{\mathrm{a}}$ serie, $\mathrm{n}^{\mathrm{o}} 20$, Santiago, 1989 , pp. 585-594.

1 "España y Europa. Un pasado jurídico común”, en Actas del I Simposio Internacional del Instituto de Derecho Común, Murcia, 1986, pp. 45-61.

2 Sobre esto en general, puede verse Francisco Tomás y Valiente, Manual de Historia del Derecho Español, $2^{a}$ edición, Madrid, 1980, pp. 307 y ss. Francisco Carpintero afirma que los juicios negativos sobre "la influencia de las corrientes humanistas en la jurisprudencia española” del siglo XVI "necesitan ser revisados” (“'Mos italicus', 'mos gallicus' y el huma- 
interés es, por cierto, observar la participación indiana en ese movimiento intelectual.

Según Coing, aquella imagen clásica acerca del desarrollo del Derecho común fue construida por los historiadores del siglo XIX, bajo la influencia decisiva de Savigny y del relieve asignado a la cultura renacentista. Debe también señalarse, entre otros factores concurrentes, el influjo ejercido por el enfoque de una historiografía jurídica concebida en nivel nacional y no europeo. Aquella imagen nos presenta los orígenes en la ciencia ítalo-francesa de la Edad Media, luego sobreviene una etapa de reforma sustancial con el humanismo del siglo XVI debido ante todo a la jurisprudencia francesa, después sigue un florecimiento de dicha ciencia entre los juristas del norte de los Países Bajos, y finalmente ocurre un nuevo cambio con el iusnaturalismo racionalista de fines del siglo XVII y de la centuria siguiente. Según este criterio, la polémica entre mos italicus y mos gallicus constituye un acontecimiento decisivo en la jurisprudencia del Quinientos. Coing afirma que, dentro de esta concepción historiográfica, "la ciencia jurídica italiana pierde importancia ya en el siglo XVI, y no se presta atención en absoluto a los autores españoles" ${ }^{3}$

Para llevar a cabo la rectificación que estima necesaria, el maestro alemán coloca su atención sobre todo en tres puntos, a saber: la literatura del Derecho común de los siglos XVI y XVII, desenvuelta en forma paralela a los escritos humanistas; el humanismo jurídico, particularmente en Francia; y la "Teología moral neotomista española". Veamos brevemente cada uno de ellos.

En cuanto al primero, destaca la conveniencia de valorar las obras escritas por italianos, franceses y españoles, y también por algunos alemanes, tanto en las que tratan sobre el Derecho común como en las que se ocupan de los ordenamientos locales. Estas obras, que siguieron los moldes de la jurisprudencia tradicional, alcanzaron una vasta circulación europea. Representaron

nismo racionalista" en Ius Commune, VI, Frankfurt am Main, 1977, p. 149). Un buen marco para futuras indagaciones al respecto ofrecen el estudio de José LuIS DE LOS Mozos, "Humanismo y 'mos gallicus' en la Escuela de Salamanca", reproducido en su obra miscelánica Metodología y Ciencia en el Derecho Privado Moderno, (Madrid, 1977, pp. 281-316) y la obra de Jean-Marc Pelorson, Les letrados juristes castellanos sous Philippe III. Recherches sur leur place dans la société, la culture et l'Etát, Le Puy-en-Velay, 1980. Traducción española: Valladolid, 2008.

3 Corng, La contribución..., cit., p. 49. 
la base del tratamiento científico y de la práctica, y tuvieron una decisiva importancia para que el Derecho común permaneciera en vigor. Su aporte debe colocarse junto con los escritos de orientación humanista. ${ }^{4}$

El segundo punto aparece estimulado por una sugerente hipótesis, según la cual "debemos juzgar la influencia del humanismo de manera esencialmente diferente a como lo ha hecho la doctrina tradicional". 5 Distingue Coing dos orientaciones principales en el humanismo jurídico: el histórico-filológico, empeñado en la crítica de fuentes, especialmente en el Corpus Iuris; y el que relativiza el derecho romano y acentúa las peculiaridades locales, que él aprecia con mayor énfasis en Francia. La misma exposición del profesor alemán autoriza - a mi juicio - la introducción de una tercera vertiente, entramada con las anteriores pero con propia individualidad: es la de los escritos expositivos, críticos y reformadores, en los cuales se exterioriza una presentación y una argumentación más libres, apoyadas en la historia, la filosofía y la literatura antigua y medieval. ${ }^{6}$ Esta apertura encuentra sustentación en el objeto amplio que Coing establece para el humanismo jurídico. Consiste éste en el tratamiento de "los textos jurídicos con la ayuda de los métodos generales desarrollados por los humanistas".

La concepción dominante nos ha ofrecido - con cierto deleite literario una ríspida confrontación entre el mos italicus y el humanismo históricofilológico. Coing sugiere no exagerar esta confrontación ya que - dice "muy pronto se conectaron las nuevas orientaciones con la tradición medieval", apoyándose para ello en los ejemplos de Tiraquello y sobre todo de Covarrubias. ${ }^{8}$ Esta conexión de las distintas líneas del humanismo con la práctica constituye, en mi opinión, una importante pauta metodológica descuidada con frecuencia - que tiende a mostrarnos una evolución pausada y acumulativa, más propia del saber jurídico que aquella otra sujeta a abruptos antagonismos o saltos repentinos.

Por fin, Coing se ocupa, en el tercero de los puntos enunciados, de "la influencia de la Teología Moral española sobre el desarrollo posterior del

4 Ídem, pp. 51, 52 y 54.

5 Ídem, p. 57.

6 CARpintero denomina esta vertiente como "humanismo racionalista", estudiándola en la primera mitad del siglo XVI (“'Mos italicus'...”, cit., pp. 111-112).

7 CoIng, La contribución..., cit., p. 54.

8 Ídem, p. 57. 
Derecho común". Se trata de los inicios de "otro ordenamiento jurídico científicamente elaborado", el Derecho Natural, cuyo desenvolvimiento posterior estaría a cargo del iusnaturalismo racionalista. Entre la nueva disciplina y el viejo Derecho común se suscitaron "mutuas influencias" en materias concretas, más allá de las hasta ahora conocidas."

Ya en sus conclusiones Coing vuelve a hacer interesantes consideraciones sobre el mundo hispánico. Plantea entonces su extrañeza por la ausencia de la literatura jurídica española y portuguesa en la concepción alemana sobre el desarrollo del Derecho común, si se tiene en cuenta la importancia histórica general, política y cultural alcanzada por la Monarquía española en el siglo XVI. Señala, como ejemplo de ello, la expansión europea que tuvo el mayorazgo castellano. Insiste en destacar, además del influjo de la neoescolástica, "la aportación de la ciencia jurídica española del siglo XVI y principios del XVII" con obras que "han ejercido una poderosa influencia europea", citando los nombres de Antonio Gómez y de Diego Covarrubias. Caracteriza las obras de este último como una combinación entre la jurisprudencia tradicional y las nuevas orientaciones provenientes del humanismo. Finaliza poniendo de relieve el cultivo del humanismo en la Universidad de Salamanca. ${ }^{10}$

\section{Significado de la propuesta}

Este ajustado escrito del profesor Coing no es enteramente novedoso pero tiene el mérito de haber planteado de modo preciso, de una parte, la caducidad de la conocida imagen acerca del desarrollo del Derecho común en aspectos nucleares - que ya estaba deteriorada por una incesante labor monográfica -, y de otra, la apertura de rumbos nuevos a la tarea de investigación histórica en este campo. No puede tampoco dejarse de mencionar la circunstancia de que este planteo parta de la pluma de una reconocida autoridad científica en la materia, preocupada por el estudio del pensamiento jurídico europeo de la Edad Moderna. Por ello estimo que esta conferencia marca un hito en el progreso de nuestros conocimientos.

9 Ídem, pp. 50 y 57.

10 Ídem, pp. 59-60. 
Quienes cultivamos el Derecho indiano nos sentimos próximos a ese escenario en que se desenvuelve el Derecho común, pero por la índole de nuestros estudios tenemos un ángulo visual algo diferente. Lo indiano se integra en ese mundo hispano que el profesor Coing impulsa a conocer mejor. Si por un lado el Derecho castellano es uno de los elementos constitutivos más importantes del indiano, por otra parte, ¿quién podría sostener que los juristas castellanos de los siglos XVI y XVII actuaban con prescindencia de lo que acontecía en ese extendido conjunto de pueblos hispanos?

La mentada exclusión del mundo hispánico llevó también por arrastre a que el historiador del derecho europeo desatendiera el fenómeno de expansión del Derecho común a nuevos y vastos territorios en el siglo XVI, con su consiguiente crisis y formación de un nuevo Derecho, el denominado indiano. Este fenómeno de expansión tiene interés no sólo por las novedades que conlleva, sino por la duración y permanencia del mismo, ya que a partir de entonces la América latina - en su sentido más exacto - quedó incorporada a un ordenamiento y a una mentalidad enraizados con aquel Derecho común.

De tal modo, esta propuesta que comentamos lleva entonces no sólo a una consideración de lo hispano-peninsular, sino necesariamente a la secuencia hispano-americana, ¿por qué puede acaso entenderse la Monarquía española de los siglos XVI y XVII sin las Indias?, ¿puede comprenderse la raíz del pensamiento teológico-jurídico sin reparar en el poderoso estímulo que recibe de los "hechos americanos"?, ¿puede entenderse a la Teología Moral, tan vivamente desplegada entonces, marginando esos hechos?, : puede conocerse la mentalidad jurídica castellana de entonces sin tener presente el horizonte extendido que tenía el jurista? En fin, ¿cómo no profundizar los efectos que sobre el Derecho tuvo ese suceso nuevo que, como decían los escritores del siglo XVI, era el más importante en la historia del mundo después del nacimiento de Cristo?

En muchos aspectos - y más aún en lo que se refiere al pensamiento y a la mentalidad - el fenómeno castellano-indiano constituye un entramado difícil de separar. Ni el jurista ni el teólogo fueron entonces sabios encerrados en sus gabinetes de trabajo, aislados del mundo. La realidad cambiante ha sido agente estimulante para nuevas ideas y para la transformación del Derecho. El despliegue alcanzado por los teólogos españoles del siglo XVI en buena parte se cimenta - como es sabido - en los problemas indianos. Cabría indagar mejor acerca de la importancia que éstos pudieron tener en la labor de los juristas peninsulares de la época. 
Las propuestas científicas de Coing tienen un efecto que, en mi opinión, lleva a revisar, desde los mismos fundamentos, ese edificio intelectual construido por los historiadores del derecho europeos a partir del siglo XIX y cristalizado en la imagen ya descripta. Esto es así porque el ingreso de los autores hispanos - hasta ahora silenciados - conduce a replantear varias cuestiones, entre ellas unas centrales que son de particular atención: las relaciones entre Humanismo y Teología y entre Humanismo y Derecho hispánico. Ya quizá no sirven las antiguas definiciones del humanismo, o particularmente las del humanismo jurídico, dadas en base a esa exclusión. Aunque el profesor Coing no trata estas cuestiones, es evidente que al establecer con amplitud el objeto del humanismo jurídico, nos está orientando hacia un criterio historiográfico que permita su inclusión.

El decidido ingreso de la Teología en este círculo de problemas a considerar dentro del humanismo jurídico lleva también a matizar ciertas tajantes nociones que enfrenta a esa disciplina con un proceso de secularización del Derecho, reemplazándolas por unas líneas de continuidad y paulatina transformación que explican, posiblemente de modo más satisfactorio, el ritmo histórico que las imágenes de ruptura y de súbita aparición de ideas y conceptos en un momento dado.

Sirvan estas breves consideraciones - a las que tanto podría agregarse - para justificar el interés que tiene extender los criterios expuestos por el profesor Coing al ámbito de nuestros estudios de Derecho indiano, con las adaptaciones - y acaso matizaciones - exigidas por la materia a tratar.

\section{Sobre la literatura jurídica hispana}

¿Cuáles han sido las razones por las que los juristas hispanos han estado casi totalmente ausentes en los esquemas de los historiadores europeos? En primer lugar, ha ejercido una indudable influencia la declinación de la Monarquía española a partir de mediados del siglo XVII, con el consiguiente empinamiento de sus enemigos del norte de Europa. A factores de hegemonía política o de poder económico, se sumó entonces la confrontación religiosa, en la que España actúo como vanguardia del catolicismo. También en el orden cultural se fue perdiendo el influjo europeo que en el siglo XVI había tenido la producción científica peninsular y la misma lengua castellana. Es aquí oportuno agregar que, ya entrando en el siglo XVIII, la lengua latina, natural trasmisora del saber, fue cediendo su posición hegemónica al francés 
- lengua entonces con creciente prestigio europeo y en proceso de expansión cultural. El mundo dieciochesco se alejó así de cierta literatura teológica y jurídica, siendo la hispánica - escrita en latín y en castellano - la que sufrió el desmedro más pronunciado, ya que desde un lugar dominante en el siglo XVI y principios del XVII descendió hasta la marginación o silencio a fines de la centuria siguiente. Sugestivo ejemplo de estos efectos puede ser la "segunda vida" que gozaron algunas obras magnas del iusnaturalismo, como las de Grocio y Pufendorf, a partir de sus traducciones francesas, beneficio que no se extendió a los autores hispanos. La misma Ilustración española - si bien hoy podemos descubrir en la misma una vertiente que volvió hacia su propio siglo XVI - estuvo en el orden cultural más atenta a los potentes influjos externos, en los cuales apoyó su labor creativa, pese a que, por necesidades prácticas, se reeditaron conocidas obras jurídicas de las anteriores centurias.

Dentro de este marco general, los historiadores del derecho europeos del siglo XIX y en parte del XX, más preocupados por atender a la peculiaridad de su propia nación, no han reparado en esta literatura hispana, olvidada por los acontecimientos. Quedó así sepultada una expresión cultural, que hoy los historiadores proceden a exhumar.

La falta de una historia del pensamiento jurídico hispánico - o de una historia de la ciencia del Derecho, si se prefiere - no ha permitido hasta ahora cumplir con ese acto necesario. Esa literatura, como bien apunta Coing, ha quedado silenciada en su contribución al derecho común, salvo en la ocasional mención de algún autor. En cambio, el aporte de la Teología española ha sido más apreciado gracias a los numerosos estudios producidos, especialmente en el último medio siglo, tanto dentro como fuera del mundo hispánico. Su contribución al desenvolvimiento de la ciencia jurídica europea, centrada sobre todo en la formulación de conceptos fundamentales en la elaboración de las bases doctrinales del derecho, ha quedado reconocida - en general y con distintos alcances - en significativas obras de conjunto europeas de los últimos tiempos, como las de los alemanes Franz Wieacker, ${ }^{11} \mathrm{y}$

11 Franz Wieacker, Historia do Direito Privado Moderno, ed. portuguesa, 1980. Esta traducción corresponde a la segunda edición revisada de la obra en alemán (Göttingen, 1967), pp. 297, 320-321 y 326. 
Helmut Coing, ${ }^{12}$ las de los italianos Guido Fassó ${ }^{13}$ y Adriano Cavanna, ${ }^{14}$ y la del francés Michel Villey. ${ }^{15}$ Debe también mencionarse en el mismo sentido el Encuentro de estudio sobre "La seconda Scolastica nella formazione del diritto privado moderno" convocado en Firenze en 1972 por el profesor Paolo Grossi, ${ }^{16}$ sin olvidar - claro está - los escritos precursores de Hans Thieme. ${ }^{17}$ Caben profundizaciones y discrepancias en un campo donde se está aún lejos de haberse alcanzado definitivas conclusiones. Lo que ha quedado asentado, por cierto, es que la teología española dio un vigoroso desenvolvimiento a esa nueva disciplina tan importante en el mundo moderno, el Derecho Natural. No es vano repetir aquí que los comienzos de esa formulación están vinculados al acontecimiento más espectacular con que se inauguró la modernidad: el descubrimiento de América.

En cambio, la literatura jurídica hispana no ha tenido igual acogida. Coing recuerda como ejemplos, a libros de Molina, Salgado de Somoza, Azevedo y Antonio Gómez. De éste y de Covarrubias dice que sus obras "fueron extraordinariamente citadas en la literatura alemana del Derecho común en el siglo XVIII". ${ }^{18}$ Estimo que en este orden los estudios exigen una ingente labor para descubrir y valorar - en su dimensión hispana y europea - un importante número de libros y escritos jurídicos, civiles y canónicos. ${ }^{19}$ No basta verificar sus citas para determinar la proyección euro-

12 Helmut Coing, Europäisches Privatrecht, I, Älteres Gemeines Recht (1500 bis 1800), München, 1985, pp. 36-37, 182, 190-191, 478 y 510.

13 Guido Fassó, Historia de la Filosofía del Derecho, edición española, t. II, Madrid, 1979, pp. 57-66.

14 Adriano Cavanna, Storia del diritto moderno in Europa. Le fonti e il pensiero giuridico, I, Milano, 1979, pp. 329-330.

15 Michel Villey, La formation de la pensée juridique moderne, $4^{\mathrm{a}}$ edición, París, 1975, pp. 341-395.

16 La Seconda Scolastica nella formazione del diritto privado moderno. Incontro di Studio. Atti a cura di Paolo Grossi, Milano, 1973.

17 Hans Thieme, "El significado de los grandes juristas y teólogos del siglo XVI para el desenvolvimiento del Derecho natural", en Revista de Derecho Privado, Madrid, julio-agosto 1954; y "La significación de la Escolástica tardía española, para la Historia del Derecho Natural y del Derecho Privado", en Universidad, 12, Universidad Católica de Santiago de Guayaquil, 1971, pp. 71-80.

18 CoIng, “La contribución...," cit., p. 60.

19 Puede verse un sugestivo anticipo de esta materia en Javier Malagón-Barceló, La literatura jurídica española del siglo de oro en Nueva España. Notas para su estudio, México, 1959, pp. 17-33. 
pea, es preciso constatar en qué medida su elaboración intelectual pudo contribuir al progreso del conocimiento, aún en el silencio de sus nombres. Aspecto central de este movimiento intelectual es el humanismo jurídico, cuyo mismo concepto y contenido hoy dominante el profesor Coing propone revisar, dándole pautas más abiertas, según hemos visto. ¿En qué medida y hasta qué punto podemos hablar de un humanismo jurídico hispano, determinando en su caso la contribución prestada y la influencia recibida del resto de Europa? En contraste, ¿qué valor conceptual y qué contenido ideológico tiene la difundida expresión mos italicus tardío? Desde luego, de particular interés para nosotros es indagar sobre la incidencia que ello tuvo en el Derecho indiano, verificando así también el grado de expansión del Derecho común en los nuevos territorios americanos.

En este sentido es muy provechosa la superación de una orientación meramente histórico-filológica en el humanismo al permitir el surgimiento de otras vertientes, que hemos destacado. Así Francisco Carpintero apunta el fuerte arraigo que tuvieron en España estas últimas, que ejemplifica en autores del siglo XVI, tales como Arias Pinellus, Martín Azpilcueta, Fortún García, Miguel de Ulzurrum, Fernando Vázquez de Menchaca, Diego de Covarrubias y Alfonso de Castro. ${ }^{20}$ Ahora bien, en obras y escritos de los juristas hispanos - castellanos e indianos - datados entre los años 1550 a 1650 podemos encontrar también interesantes muestras de esas otras vertientes humanísticas. La acentuación de las peculiaridades jurídicas locales, la relativización del Corpus Iuris y de sus comentaristas, la crítica al orden existente y las propuestas reformadoras pueden observarse en esa producción literaria, a través de una argumentación y presentación más libres, en donde se invocan como elementos incitativos fuentes literarias, históricas y filosóficas antiguas y medievales. Un elenco de juristas españoles esbozan, entre fines del siglo XVI y principios del XVII, el primer paso de un movimiento de crítica y reforma del Derecho que se adelanta a otras expresiones europeas, aunque sin consecuencias inmediatas. A los nombres principales de Jerónimo Zevallos, Tomás Cerdán de Tallada ${ }^{21}$ y Lope de Deza, ${ }^{22}$ podríamos agregar los de

20 Carpintero, “'Mos italicus'..., cit., 145-150.

21 Teresa Canet Aparisi, Vivir y pensar la politica en una Monarquía plural. Tomás Cerdán de Tallada, Universitat de Valencia, 2009.

22 Víctor Tau Anzoátegui, “El 'juicio de las leyes civiles' de Lope de Deza. Una obra crítica y reformadora en tiempos de Felipe III", en Revista de Historia del Derecho, núm. 13, Buenos Aires, 1985, pp. 479-530. 
Bartolomé de Albornoz ${ }^{23}$ y Francisco Bermúdez de Pedraza en aspectos muy concretos. Secunda este movimiento el humanista aragonés Pedro Simón Abril. ${ }^{24}$ Diversas circunstancias - que no es del caso explayar aquí - han silenciado esos escritos, hoy ignorados por los historiadores europeos y aún poco conocidos en la misma España.

El trasplante del Derecho común y del castellano junto con la formación de un nuevo Derecho allende el océano dio lugar a una postura creativa, en la que el humanismo deja sus huellas, Máximos expositores son juristas como Juan de Matienzo, ${ }^{25}$ Juan de Ovando, y décadas después, Antonio de León Pinelo y Juan de Solórzano Pereira. En niveles distintos, estos juristas se vieron obligados a alejarse de la jurisprudencia tradicional ante las nuevas situaciones planteadas por una realidad diferente a la del Viejo Mundo, relativizando así el influjo del derecho romano, aunque sin desprenderse del mismo y siendo en algunas materias apoyo insustituible. Aunque estos juristas indianos son bien conocidos por los estudiosos americanistas, estimo que aun mucho puede indagarse en sus obras y escritos sobre su posible encuadre en las diferentes vertientes del humanismo jurídico.

Estas páginas, que ofrezco como contribución al homenaje promovido por la comunidad académica chilena a don Alamiro de Ávila Martel, querido amigo y eminente colega, son nada más que un modesto estímulo para desenvolver un tema nuclear en nuestra disciplina, que está reclamando una profunda investigación. Por esto mismo cabe mantener el título del trabajo entre signos de interrogación, aunque de mi parte haya adelantado ya algunos puntos de vista que me hacen tomar posición en su futura respuesta.

23 Eduardo Soto Kloss, "El 'Arte de los contratos' de Bartolomé de Albornoz, un jurista indiano del siglo XVI', en Revista Chilena de Historia del Derecho, núm. 11, Santiago, 1985, pp. 163-185, especialmente pp. 179-180.

24 Alejandro Guzmán Brito, "Estudios en torno a las ideas del humanismo jurídico sobre reforma del Derecho (1). Un humanista español frente al Derecho de su época: Pedro Simón Abril”, en Revista de Estudios Histórico-Jurídicos, IX, Valparaíso, 1978, pp. 167-185.

25 Víctor Tau Anzoátegui, "El 'Gobierno del Perú' de Juan de Matienzo. En la senda del humanismo jurídico", en Eroberung und Inbesitznahme Amerikas im 16. Jabrhundert. Rechtfertigung, Realität und literarische Reflexion. Internationales Symposium, Eichstätt, 1988. Reproducido en el presente volumen (III). 


\section{El Gobierno del Perú de Juan de Matienzo. En la senda del humanismo jurídico*}

Sumario: 1. Introducción: el autor y la obra -2 . Sobre el humanismo jurídico 3. Fuentes utilizadas -4 . El predominio de la lengua castellana - 5. Realidad, utopía y proyectismo - 6. Postulados ético-morales - 7. La idea de Derecho - 8. Epílogo

\section{Introducción: el autor y la obra}

Me propongo examinar el Gobierno del Perú de Juan de Matienzo desde un ángulo visual particular, mostrando a través de algunas cuestiones representativas el entramado de ideas que nutre la obra en estrecha relación con la crítica situación que, por esos días, atravesaba el virreinato peruano.

La obra que es objeto de nuestra atención ha tenido una singular trayectoria, que conviene recordar brevemente. Escrita en 1567 en el Perú, alcanzó - según veremos - difusión e influjo a través de ejemplares manuscritos. Sólo en 1967 - cuatro siglos después - apareció impresa por primera vez una versión integral de la misma, obtenida de dos copias de época. ${ }^{1}$ Lamentablemente la edición carece de las notas marginales que su autor puso en el original, cuyo paradero se desconoce. No obstante, constituye un significativo avance sobre el texto bastardo que vio la luz en $1910 .^{2}$ Las circunstancias apuntadas explican que el Gobierno del Perú haya permanecido durante largo tiempo alejado de la vista de los historiadores, sin poder ser examinado y utilizado como fuente de conocimiento para la historia americana en general y para la jurídica en particular.

* Publicado en De conquistadores y conquistados. Realidad, justificación, representación. Editado por Karl Kohut en colaboración con Jürgen Bähr, Ernesto Garzón Valdés, Sabine Horl Groenewold y Horst Pietschmann, Vervuert Verlag, Frankfurt am Main, 1992, pp. 168-187. Edición en alemán: KarL Kohut (Hg.), Der eroberte Kontinent. Historische Realität, Rechtfertigung und literarische Darstellung der Kolonisation Amerikas. Vervuet Verlag, Frankfurt am Main, 1991, pp. 135-157.

1 Juan de Matienzo, Gobierno del Perú (1567), Edition et Etude préliminaire par Guillermo Lohmann Villena. Travaux de l'Institut Français d'Etudes Andines, Paris-Lima, 1967.

2 Juan de Matienzo, Gobierno del Perú. Obra escrita en el siglo XVI por..., Facultad de Filosofía y Letras. Sección de Historia, Buenos Aires, 1910. 
Como introducción a aquella edición, Guillermo Lohmann Villena publicó un apreciado estudio, en el cual sobresale una nueva y exhaustiva información sobre el autor y la obra, así como una ajustada descripción del momento histórico en que la misma fue redactada. En este último sentido Lohmann caracteriza como de "expectante incertidumbre" el decenio que se inició con la llegada de Matienzo a Lima, en febrero de 1561. Durante el mismo, la sociedad, la economía, el gobierno, la Iglesia y las relaciones con los indígenas fueron enjuiciadas. Dejemos a la pluma del mencionado autor el esbozo del cuadro:

En el decenio que corre de 1560 a 1570 estalla un auténtico enardecimiento por auscultar la realidad, por indagar sistemáticamente y calar a fondo los núcleos sociales que se trataba de incorporar a los esquemas de la civilización cristiana. Una actitud colectiva de verdadera controversia absoluta se expande cada vez más perceptible, al grado de cuestionar la esencia misma de la empresa desarrollada hasta entonces por la Corona, las autoridades civiles y la jerarquía eclesiástica, los encomenderos y los doctrineros, así como la razón de ser de los principios cardinales de la política indiana y la eficacia de los métodos observados en orden a la acción misional desplegada en el seno de la población autóctona. ${ }^{3}$

Bajo forma interrogativa plantea el autor los posibles factores que condujeron a esta situación crítica, desenvolviendo un variado número de hipótesis - económicas, místicas o religiosas, sociales, demográficas, políticas - para ahondar la cuestión, anticipando la posible interrelación de todas ellas. ${ }^{4}$

Esta preocupación generalizada dio origen entonces a un abundante número de escritos surgidos con distintos fines pero que convergían en el examen de los problemas acuciantes, ya fuese para escudriñar el pasado indígena, ya fuese para reflexionar críticamente sobre la situación del momento, ya fuese para impulsar reformas. Dentro de este complejo marco histórico se ubica la obra de Matienzo. Lohmann la considera como "cúpula o coronación" de ese movimiento, que condujo "de la anarquía ideológica en que se debate el Perú entre 1560 y 1570 a la serena formulación legislativa”

3 Guillermo Lohmann Villena, Juan de Matienzo, autor del 'Gobierno del Perú' (su personalidad y su obra), Escuela de Estudios Hispanoamericanos, Sevilla, 1966-1967. Es separata del Anuario de Estudios Americanos, t. XXII, Sevilla, 1965, pp.767-886. Este estudio se publicó en francés como introducción al volumen citado en nota 1.

4 Ídem, pp. 8-11. Véase también Ismael Sánchez Bella, “El gobierno del Perú, 1556-1564”, en Anuario de Estudios Americanos, XVII, 1960, Sevilla, pp. 407-524. 
del virrey Toledo. ${ }^{5}$ Si toda producción literaria guarda relación con el clima social en el cual se incuba, en el caso de la obra que examinamos esas vinculaciones fueron más fuertes y estrechas.

Cabe preguntarse sobre la personalidad de este jurista, nacido en Valladolid en 1520, egresado en leyes de la universidad local, y desde muy joven empleado en la Chancillería de la misma ciudad, donde alcanzó a ocupar la plaza de relator. En la metrópoli castellana de entonces, Matienzo debió absorber tanto la vigorosa presencia de las corrientes humanistas como las controversias que se desataban en torno a las lejanas Indias. Sin que verdaderamente se conozcan los motivos determinantes, aceptó una plaza de oidor en la nueva Audiencia de los Charcas, para la cual fue designado en 1558. Justo ese mismo año daba a luz su primera obra, el Dialogus Relatoris et Advocati Pintiani Senatus [...] En forma dialogada, Matienzo disertaba en este libro sobre las obligaciones de jueces, relatores y abogados en el superior tribunal.

Luego de un largo viaje, el flamante oidor arribó a Lima, con su familia, en febrero de 1561. Curioso e inquieto, sus observaciones en la penosa travesía sirvieron ya de punto de partida para la nueva obra que empezaba a concebir. Permaneció en esa plaza de oidor hasta su muerte en 1579, no regresando nunca al suelo natal ni alcanzando ascenso alguno en su carrera burocrática. Lohmann ha proporcionado interesantes pormenores sobre su vida en la Plata - ciudad entonces incipiente, fundada sólo veintidós años antes de la llegada del oidor -, acerca de la familia y amigos, con sabrosos episodios de su vida privada. Sus días peruanos transcurrieron entre alegrías y penas, pero a la postre estuvieron signados por el desengaño y olvido de las autoridades supremas, que no premiaron su consagración a las tareas encomendadas. Tuvo, con todo, su momento de esplendor. Fue cuando mereció el aprecio del virrey Toledo, quien se sirvió de sus trabajos, aprovechando algunas de sus propuestas en la elaboración de su estimada labor legislativa. ${ }^{6}$ Lo tuvo por uno de sus consejeros predilectos. La gloria terrenal le acompañó empero pocos años.

5 Lohmann Villena, Juan de Matienzo..., cit., pp. 31-32.

6 Francisco de Toledo, Disposiciones gubernativas para el Virreinato del Perú. 1569-1574, Escuela de Estudios Hispanoamericanos, Sevilla, 1986, Introducción por Guillermo Lohmann Villena; transcripción por María Justina Sarabia Viejo, p. XXII. 
Durante su residencia en el Perú, más allá del desempeño de sus funciones específicas, se dedicó a la producción jurídica. Junto con el Gobierno del Perú concluyó en 1567 otro libro, Estilo de Chancillería, que también quedó inédito. Sólo lo conocemos a través de referencias. En 1576 envió a España otras dos obras, una de las cuales era el comentario de su libro quinto de la Nueva Recopilación, escrita en latín, que se imprimió en Madrid en 1580, un año después de su muerte. ${ }^{7}$ Tuvo así Matienzo la suerte adversa de que, siendo prolífico escritor, sólo pudo en vida ver impreso aquel Dialogus vallisoletano.

Sin embargo, el Gobierno del Perú no corrió la desventura de otros manuscritos que los coetáneos condenaron al olvido. Enviado a la Península en el mismo año en que se concluyó su redacción, con el propósito de imprimirlo, Lohmann conjetura que se tuvo a la vista en la Junta Magna de 1568 y que fue texto de consulta en el Consejo de Indias. Circularon entonces algunas copias y extractos. Las repetidas menciones que Solórzano hizo de esta obra, sobre todo en la Política Indiana, contribuyeron, sin duda de modo decisivo, a asegurarle un lugar destacado dentro de la producción jurídica del siglo $\mathrm{XVI}^{\mathbf{8}}$

Esta situación no fue anómala. Conviene recordar que una buena parte de los libros fundamentales referentes a América permanecieron sin imprimirse hasta una época relativamente reciente (fines del siglo XIX y principios del $\mathrm{XX)}$.

Entrando ya en el análisis de la obra, recordemos que Lohmann sostiene que "con el Gobierno del Perú se supera por vez primera la literatura narrativa de los cronistas o el corto vuelo de los escritos de ocasión, para exponer un ambicioso programa político y un plan de acción orgánico", en el que no faltaban los puntos sustanciales en debate. Estima el mismo autor que constituye "el embrión del primer cuerpo legal peruano". En sentido análogo,

7 En la Biblioteca Universitaria de Salamanca, se encuentra en el fondo antiguo de impresos y manuscritos (mss. 2195) un volumen encuadernado en cuero (en el lomo se lee: Matienzo, commentar.) que contiene varios cuadernillos manuscritos que corresponden a comentarios de los libros séptimo y octavo de dicha Nueva Recopilación en estado de elaboración parcial de una obra que no llegó a concluirse.

8 Lohmann Villena, Juan de Matienzo..., cit., pp. 114 y ss.

9 Ídem, 110. Es mucho más radical la tesis de Miguel Bonifaz, "El licenciado Don Juan de Matienzo, oidor de la Real Audiencia de los Charcas, el verdadero legislador del Perú”, en Revista de Estudios Jurídicos, Políticos y Sociales, año IX, núms. 19-20, Sucre, 1947, pp. 59-72. 
otro autor afirma que la obra, basada en supuestos jurídicos, es una "decisiva planificación para la construcción de un plan político de gran aliento y de grandes posibilidades por su esencial vinculación con la realidad más estricta". ${ }^{10} \mathrm{Mi}$ interés - y por ende el objetivo preciso de estas páginas - apunta a conocer las bases sobre las cuales se sustenta esa construcción y a ubicar la obra dentro del pensamiento jurídico de la época.

El Gobierno del Perú no se encuadra dentro de un género literario convencional. Es un libro jurídico, planeado y redactado con más libertad, con la misma libertad que encontraba el recién llegado al Nuevo Mundo. Esto mismo impide tal vez que la estructura alcance solidez y el método empleado su adecuado rigor. Dividido en dos partes bien concebidas - la de los indios y la de los españoles -, no siempre su contenido guarda coherencia con esa gran división. Es además obra de despliegue desigual, en cuanto a su temple literario, a su hondura reflexiva, y aun en cuanto al material que interesa extraer para nuestro objeto. A capítulos de vigor conceptual y de cierta belleza estilística les suceden otros planamente descriptivos. A veces, el hilo de la exposición sufre abruptas intrusiones, algunas de no poco interés, pero que se desvían del asunto en tratamiento. Puede en algunos pasajes ofrecer la impresión de una obra necesitada de un ajuste final. No obstante todas estas limitaciones, ofrece un rico caudal de noticias, reflexiones críticas y propuestas que dan fuerza a la estimación generalizada que de la misma se ha efectuado.

Según confesaba Matienzo, había tratado de "entender de raíz las cosas de este Reino del Perú”, tanto en lo tocante a indios como a españoles, siendo su propósito "declarar los medios que se podrán dar para conservar la tierra y para que los indios sean aprovechados, ansí en lo espiritual como en lo temporal, y alcancen la libertad que algunos llaman, sin dar la orden como pueden salir de la servidumbre", y también buscar el provecho y aumento de la real hacienda "sin daño de nadie". Partía pues Matienzo de una postura clara, en medio de las controversias que agitaban al Perú y aun a todo el mundo americano: la conservación de la tierra; el provecho de los indios y el incremento de la haciendo real.

10 Mario Hernández Sánchez-Barba, Historia y literatura en Hispano-América (1492-1820): la versión intelectual de una experiencia, Madrid, 1978, pp. 17 y ss. 


\section{Sobre el humanismo jurídico}

Para penetrar en las bases de sustentación del Gobierno del Perú es preciso conocer la mentalidad e ideas que rodeaban a Matienzo en la época de su formación y de la elaboración de la obra. Entonces, en esos años centrales del siglo XVI, maduró un humanismo con impulso renacentista que se encarnó en los españoles que llegaban a América. Estaban sensibilizados para apreciar el paso del tiempo y para comparar unas culturas con otras. Los rodeaban las novedades etnográficas, políticas, militares y técnicas. Su espíritu estaba abierto a nuevos campos de dominio y acción. Desde este punto de vista, Maravall - en reiterados estudios - ha establecido el carácter peculiar del Renacimiento español. ${ }^{11}$ Dentro de este clima cabe, a mi juicio, apreciar el desenvolvimiento castellano-indiano del humanismo jurídico.

La noción de humanismo jurídico ha estado acotada, durante mucho tiempo, por límites conceptuales y especiales demasiados estrechos. Una línea historiográfica arraigada y difundida hasta hoy, puso de relieve en el humanismo jurídico una estimable labor de crítica de las fuentes, acompañada de severos juicios contra el Corpus Iuris y sus comentadores medievales. Algunos, sin más, redujeron el humanismo jurídico a estos ejercicios filológicos o al erudito rescate de textos o noticias del mundo clásico con vistas a una reconstrucción jurídica integral.

No hay duda que esta corriente fue un componente de ese humanismo que hizo un decisivo aporte en el saber teórico del jurista, con influjo diferido sobre la praxis. Pero también se perciben en el humanismo jurídico - más allá de la estrecha definición que del mismo se ha hecho - otras vías de desenvolvimiento, en conexión estrecha con los interrogantes que planteaba al hombre la época del Renacimiento. Me interesa ahora destacar aquella corriente que impulsaba la penetración de nuevas ideas y conceptos en el razonamiento, para lo cual los juristas se apoyaban o inspiraban con creciente libertad en la literatura, la historia, la filosofía grecolatina y medieval, rompiendo el cerco del Corpus Iuris. Si ya en los propios comentaristas medievales se registraban los primeros síntomas de ese despertar, fue en el Renacimiento cuando el jurista, exigido por los nuevos problemas que se le

11 José Antonio Maravall, Estudios de Historia del Pensamiento Español. Serie segunda. La época del Renacimiento, Madrid, 1984. 
presentaban, debió ampliar el horizonte de su conocer y razonar, sirviéndose de las nuevas disciplinas que se cultivaban. La reforma religiosa y la expansión hacia América fueron hechos decisivos para estimular el razonamiento jurídico durante el siglo XVI, encauzado principalmente a través de la renovada Teología y el nuevo Derecho Natural. Se vislumbra así un movimiento que no puede encerrarse dentro de los rígidos esquemas conocidos del "mos italicus" y del "mos gallicus". Es otra vía del humanismo jurídico, que Carpintero prefiere denominar "humanismo racionalista".

A lo largo del siglo XV se había desarrollado el humanismo en Castilla, con Alonso de Cartagena y sobre todo con Antonio de Nebrija. Como ha señalado Di Camillo, se trataba de una actitud intelectual afirmada en la controversia: Platón o Aristóteles, lengua latina o romance, estimación de los antiguos o de los modernos, a favor o en contra de Erasmo. ${ }^{13}$ Esta preocupación intelectual penetró lentamente en la Teología y en el Derecho, los dos saberes oficiales de la época. En el marco de expansión y avance castellano del siglo XVI la Universidad de Salamanca se convirtió en el principal foco de irradiación de esas disciplinas y de cultivo del humanismo jurídico. ${ }^{\mathbf{1 4}}$ Otros centros universitarios, como Alcalá de Henares y Valladolid - donde Matienzo se formó - acompañaron este movimiento cultural que ostenta - al decir de un autor - "su pretensión de incorporar valores medievales dentro de un espíritu renacentista" ${ }^{15}$

El razonamiento teológico-jurídico, intensamente motivado por el descubrimiento del Nuevo Mundo y por la cuestión religiosa, tuvo altas expresiones en Francisco de Vitoria, Domingo de Soto, Luis de Molina y Alfonso de Castro. También en Juan Ginés de Sepúlveda y fray Bartolomé de las Casas, entre otros. Sus puntos de vista renovadores incidieron sobre la esfera jurídica. Entre los juristas castellanos ubicados en la vertiente humanista, han sido destacados los nombres de Antonio Agustín, Diego de Covarrubias y

12 Francisco Carpintero, “'Mos italicus', 'mos gallicus' y el humanismo racionalista. Una contribución a la historia de la metodología jurídica”, en Ius Commune, VI, Frankfurt am Main, 1977, pp. 108 y ss.

13 Ottavio Di Camillo, El humanismo castellano del siglo XV, Valencia, 1976.

14 José Luis de los Mozos, "Humanismo y 'mos gallicus' en la Escuela de Salamanca”, en Metodología y ciencia en el derecho privado moderno, Madrid, 1977, pp. 281-316.

15 José Luis Abellan, Historia crítica del pensamiento español, t. II, Madrid, 1979, p. 171. 
Fernando Vázquez de Menchaca, ya por su labor de crítica de las fuentes romanas o canónicas, ya por sus construcciones iusnaturalistas. Los tres eran coetáneos de Matienzo.

El humanismo jurídico se torna renacentista cuando en vez de quedar inmovilizado en la imitación de los antiguos se nutre de una conciencia progresista y de una visión evolutiva dinámica de la humanidad; y estimula, en fin, el ingenio del hombre para obrar sobre la naturaleza dominándola. Bajo este concepto, estimo que el Gobierno del Perú es un ejemplo bien representativo. El espíritu humanista que trasunta Matienzo era más abierto que el de sus coetáneos castellanos, pues al encontrarse con una realidad conflictiva, intentaba dar un nuevo orden, valiéndose de los elementos a su alcance, viejos y nuevos. De ahí que era un humanismo más preocupado en operar sobre la sociedad viva que entretenido en una labor de crítica de fuentes. Esto es lo que me propongo exponer en estas páginas mostrando que el Derecho no permaneció al margen del vasto horizonte renacentista. Para ello he elegido algunos tópicos que permitirán observar el Gobierno del Perú como expresión renacentista del humanismo jurídico hispánico.

\section{Fuentes utilizadas}

Un serio escollo detiene a quien desea indagar en las fuentes literarias y legales del Gobierno del Perú. Las notas marginales que Matienzo colocó en el manuscrito original no fueron reproducidas en las copias hoy conocidas. Ante este vacío - que tal vez algún día pueda cubrirse - queda el recurso de acudir a las menciones concretas de autores nombrados en el texto mismo de la obra. Esto es lo que he realizado. En forma suplementaria y para determinadas cuestiones podría acudirse, siguiendo las indicaciones del propio Matienzo, a sus otros libros, el Dialogus y el Estilo de Chancillería, pero este último nos es hoy desconocido.

Nuestro análisis, pues, se reduce a aquellas menciones. Aplicando un criterio cuantitativo - que no deja de reflejar una orientación sustancial encontramos en primera línea a Aristóteles - 30 veces registrado - y a Platón, - con 26. Hay una apreciable diferencia con el resto de los autores, al punto que aquellos dos juntos representan cerca del $50 \%$ del total de escritores citados en la obra. Si a ello agregamos que estas menciones tienen, a mi juicio, valor sustancial en el desarrollo de la idea, nos hallamos con que la presencia de estos dos grandes pensadores del mundo clásico, apreciados por 
el humanismo, es altamente sugestiva. ${ }^{\mathbf{1 6}} \mathrm{Si}$ a Aristóteles y a Platón agregamos otros autores antiguos - como Séneca, Plutarco, el muy citado Cicerón - nos acercamos ya al $80 \%$ de menciones de esta procedencia.

Se hallan también citas de la Sagrada Escritura y especialmente de escritos de San Pablo. De los teólogos medievales, destaca la mención de Tomás de Aquino y de los modernos, Vitoria y Soto. Hay citas aisladas de Alfonso de Castro y de Luis Vives, aunque en este último caso era acompañada de la expresión "el muy famoso". Si bien sólo una vez he registrado el nombre de Las Casas, las alusiones a sus obras y puntos de vista están presentes en más de una cuestión. De los cronistas indianos, en varias ocasiones aprovecha la información de Pedro de Cieza de Léon.

En la esfera jurídica, sólo una vez acude a Justiniano, Triboniano y Alfonso X. Entre los coetáneos se destacan las menciones del francés André Tiraqueau y en menor escala los españoles Diego de Covarrubias y Luis Velázquez de Avendaño. De las últimas, acaso la más sugestiva sea la de Tiraqueau, ubicado en la línea del humanismo, ${ }^{17}$ y cuya presencia en Matienzo sería de interés profundizar pues también aparecía mencionado en el Dialogus. Las referencias concretas a fuentes legales son escasas, pero es indudable que en sus propuestas normativas - rasgo destacado de la obra - incorporó también preceptos vigentes del derecho indiano.

Ahora bien, ¿cómo eran utilizadas estas fuentes literarias? ¿Qué actitud adoptaba ante las mismas? No puede darse una respuesta única. A veces, constituían un ornato literario, otras veces operaban como apoyo teórico, no faltando las consabidas citas de autoridad. Me inclino, no obstante, a afirmar que predominaba un uso libre de esas fuentes en el sentido de constituirse en estimulantes puntos de apoyo para desenvolver las nuevas soluciones reclamadas por la sociedad que bullía en el incomparable escenario americano. No era pues la actitud de contemplar admirativamente a aquellos pensadores en un mero retorno a los tiempos clásicos, sino que Matienzo los utilizaba para abordar nuevos temas, para apoyar un movimiento de avance. Era, en suma, una postura renacentista.

16 Miguel Batllori ha señalado que en el Renacimiento español se percibe un constante deseo de coordinar el pensamiento de ambos autores (Humanismo y Renacimiento. Estudios hispano-europeos, Barcelona, 1987, p. 34).

17 Pierre Mesnard, "Andres Tiraqueau y el neobartolismo", en Revista de Estudios Políticos, núm. 56, Madrid, 1951, pp. 115-126. 
Matienzo concedía enorme valor a la experiencia, a su propia experiencia, tal como se advierte en otros escritores coetáneos, sobre todo en quienes componían historias o crónicas. Maravall dice que "la experiencia individual y concreta, como base para organizar la relación del individuo con el mundo, es lo característico del renacimiento español, o, por lo menos, lo que de nuevo se barrunta". ${ }^{\mathbf{1 8}}$ De modo más específico, el mismo autor puntualiza, en otra ocasión, como rasgo nuevo del español del siglo XVI el proclamar a la experiencia como principio del saber, dudando o rechazando el testimonio tradicional o la autoridad de la ciencia. Y agrega: "La experiencia, para este grupo de escritores, es un título universal de certificar el conocimiento de las cosas. Ella es la que ha derrocado la vieja concepción del mundo y en ella se basa la superioridad de su saber en la época", para concluir: "Ya no se trata de buscar una corroboración a lo que se alcanza especulativamente, sino que de la experiencia deriva el verdadero saber y con ella hay que estar frente a la especulación. ${ }^{19}$ Tal era el espíritu que animaba a Matienzo. Varias veces resaltaba que su obra era fruto de las observaciones recogidas de camino por ciudades y villas del Perú y de su residencia en algunas de ellas. Además, como si quisiera reforzar determinada descripción u opinión, usaba expresiones como "yo he visto por mis ojos..." Para justificar en otra oportunidad la desatención hacia cierto tema, afirmaba que "no es mi intento tratar del Perú que no he visto ni pisado". En el mismo sentido, al ocuparse del territorio de la Audiencia de Quito, pese a aclarar que tenía información sobre esa tierra, confesaba: "no quiero tratar de ella más de lo que tengo apuntado, porque no la he visto ni estado en ella, y será hablar de oídas" ${ }^{20}$

El entusiasmo por conocer nuevos pueblos y hombres, la convicción de que nada reemplazaba la posibilidad de ver las cosas con los propios ojos, llevó a Matienzo a esa pintoresca entrevista con el inca alzado Tito Cuxi Yupanqui, que relataba en un largo capítulo de la obra. Si bien este capítulo aparece insertado artificialmente en la estructura del libro - aparte de otras consideraciones - es evidente que para Matienzo revestía especial relieve presentarlo como una exaltación de la experiencia personal.

Quedaba así asentaba la preeminencia de lo visto sobre lo oído o informado. Lo decían y repetían muchos escritores del siglo XVI. Era tópico

18 Maravall, Estudios de Historia, cit., p. 115.

19 Ídem, p. 420.

20 Matienzo, Gobierno..., cit. en nota 1, pp. 8, 216, 248 y 255. 
común. No puede descartarse que en este recurso hubiera también un ingrediente de perspicacia de Matienzo para dar mayor valor a sus palabras en la Corte - hacia donde se encaminaba su obra - en confrontación con otros ministros o informantes que no habían tenido análoga experiencia. Pero en sustancia esto mismo quedaba anidado dentro de esa preferencia que gozaba la experiencia como criterio de saber, dominante en el mundo cultural hispánico y constituía uno de los peculiares rasgos de ese humanismo renacentista.

En un doble sentido se percibe en Matienzo el aprecio por el conocimiento histórico. Consciente de que el estudio del pasado requiere un arte que él no poseía, interrumpía el relato que venía haciendo acerca de los castigos divinos recibidos por españoles que habían tratado con crueldad a los indígenas para decir que dejaba otros ejemplos a "los historiadores, porque no es mi intento tratar ni contar historias".21

Es, sin embargo, el otro sentido el que me interesa destacar: la utilización de la historia como elemento de análisis y argumentación. Así le servía, por ejemplo, para distinguir los primeros tiempos de la Conquista de los que él protagonizaba, estableciendo diferencias y sobre todo subrayando el error de quienes analizaban "juntando los tiempos primeros con los presentes". 22

Acaso es más elocuente el ejemplo que observamos cuando Matienzo intentaba explicar la conquista española dentro de la naturaleza humana y en comparación con otros acontecimientos análogos. Sostenía al respecto que "nuestra humana naturaleza es muy mudable e inquieta" y, según Séneca, "ninguna cosa ha quedado en el mismo lugar a do fue engendrada". Vale la pena detenerse en este párrafo sustancial:

Cada día se muda algo en tan gran mundo como habitamos, de que son testigos los pueblos griegos que hay entre los bárbaros, y los macedonios entre los indios y los persas y los atenienses y todos cuantos habitan en Asia, los sirios en Africa, los cartagineses en España, y los griegos en Francia y los franceses en Grecia, y otros en otras partes muy lejas de su nación, porque yendo a buscar tierras nuevas, de cansados se quedaron allí, o que por fuerza de armas las conquistaron e ganaron, echando de su tierra a los naturales della, y otros a estos, y así nunca la Fortuna deja a nadie en un estado mucho tiempo.

21 Ídem, p. 14.

22 Ídem, pp. 3, 270 y 308. 
Dentro de esta reflexión histórica incluía el descubrimiento de América: "Este intento - decía - pudieron traer los españoles cuando, dejando su propia tierra, vinieron a esta tan apartada de la suya, y no el que algunos hipócritas fingen, diciendo que no vinieron con buen celo, sino movidos por codicia, juzgando los ánimos ajenos por los suyos propios”.

Despuntan en estas imágenes rasgos de una concepción secular de la historia, que se consolida con la sugestiva invocación de la Fortuna - ¿reminiscencia medieval o innovación renacentista? Esta misma explicación se mantenía inmediatamente después cuando afirmaba que "inclinación pudo ser natural y satisfacción divina para que descubriesen esta tierra, que tanto tiempo había estado tan escondida, en que su sancta palabra se cumpliera predicándose su sacrosanto Evangelio en todo el mundo" ${ }^{23}$ La inserción de la "satisfacción divina" y de la evangelización dentro del proceso de la conquista no alteraba aquella caracterización anterior, de una historia mudable, de modo natural, por imperio de la Fortuna.

\section{El predominio de la lengua castellana}

Uno de los dilemas que acuciaba a los humanistas era la preferencia, ya del latín clásico, ya de las lenguas romances. Dentro del mundo hispano, la expansión de Castilla fue acompañada por la difusión de su lengua. Aunque Matienzo escribió en latín dos de sus libros más importantes, siguiendo en esto seguramente la fuerte presencia que para entonces conservaba esa lengua en la esfera de los juristas, su preferencia lo llevaba a exaltar el castellano como habla moderna, mucho más ante la expansión del reino peninsular en América. Era, por cierto, la lengua que había que introducir en el mundo indígena, pues a través de ella - decía - los caciques e indios podrían comprender y entender mejor la doctrina cristiana, pero entre tanto los curas doctrineros deberían aprender, por uno o dos años, el habla general de los indios para predicarles los rudimentos de la fe con mayor provecho. ${ }^{24}$ Matienzo parecía considerar que era ésta última una etapa transitoria, siendo la lengua castellana la que paulatinamente se impondría dentro de la comunidad aborigen, como un elemento sustancial en el proceso de elevación del indio al nivel cultural del europeo cristiano.

23 Ídem, pp. 10-11.

24 Ídem, pp. 21 y 119-122.

56 Capítulo III 
En otro orden, vale la pena apuntar que, al dar las razones por las cuales había redactado el Gobierno del Perú en castellano, Matienzo afirmaba también con sentido renacentista - la superioridad del habla romance sobre el latín al decir que así lo había hecho "por que mejor gozen todos de él" ${ }^{25}$ Puede también conjeturarse que la elección del castellano para escribir esta obra se debiese a la naturaleza misma del material en elaboración, que era más fácil trasmitir en el idioma vivo que ganaba terreno en los tiempos modernos.

\section{Realidad, utopía y proyectismo}

Matienzo abordó la tarea con espíritu crítico. Ello estaba en su ánimo cuando se dispuso a "entender de raíz las cosas de este Reino del Perú", según decía en expresión recordada. La crítica - uno de los componentes del clima social peruano en esos años - despuntaba en muchos pasajes, ya enjuiciando al gobierno español, ya denunciando abusos cometidos contra los indígenas, ya condenando la actitud de los caciques, ya marcando a fuego la avaricia de algunos gobernantes. Pero esta postura estaba lejos de adherir a otras posiciones críticas, como la lascasiana. Tenía una orientación diferente. Era un jurista pragmático, dispuesto a apoyar el proceso de la Conquista que estaba consumado, sobre la base de un poder político, sustentado por el Derecho y presidido por pautas ético-morales. Defendía así los títulos de la Corona a los territorios americanos y justificaba la conquista del Perú por la tiranía de los incas, pero establecía las bases de un nuevo orden, basado especialmente en la experiencia recogida.

De allí que la reforma - con las consiguientes propuestas - constituyera la contracara de la crítica, su necesario complemento. Casi se podría decir que era el rasgo principal en la obra de Matienzo. Su pretensión era - según decía - "declarar los medios que se podrán dar para conservar la tierra" y para el provecho y aumento de la real hacienda. Esa reforma apuntaba a la consolidación de la Monarquía en el Nuevo Mundo, bajo ciertas "formas estatales" más modernas. Aquellos medios de acción eran asentados en ideas desenvueltas a lo largo de la obra, siendo normativamente recogidos en un con- 
junto de preceptos que cerraban el tratamiento de ciertas materias importantes.

Alguna dosis de utopía - entendido este vocablo en su prístino sentido de algo difícil, pero no imposible, de alcanzar - conlleva toda propuesta reformadora. En Matienzo esa dosis - de indudable procedencia humanista - se combinaba con un realismo impresionante y con una percepción muy clara sobre la proyección de la Monarquía sobre territorios donde aún no se había asentado la colonización.

Acudamos a algunos ejemplos representativos extraídos del Gobierno del Perú para mostrar, tanto de modo separado como articulado, los perfiles que acabo de enunciar. Estos ejemplos tienen el sentido de expresar con fuerza lo que en otros casos aparece diseminado en distintas páginas de la obra. Veamos.

Una de las preocupaciones básicas de Matienzo, que rezumaba en todo el libro, era explicar y articular la dual sociedad americana, española e indígena. Asistía por entonces nuestro licenciado a una circunstancia excepcional: el nacimiento pujante de una sociedad hispano-criolla - sobre la que ha escrito páginas esclarecedoras James Lockhardt ${ }^{26}$ - y a la transformación de otra, la comunidad indígena - acerca de la cual es preciso recordar la monografía de Steve Stern, centrada en Huamanga. ${ }^{27}$ Matienzo procuraba atender tanto a los problemas de desenvolvimiento de cada una como a los de articulación entre ambas, para insertarlas dentro de la Monarquía. Ello se prestaba para indagar hondamente en la realidad y también para concebir - cual arcilla blanda para moldear - ideas y normas en una fase proyectista, con destellos utópicos. Era un terreno fértil y seguramente muy atractivo para quien, como Matienzo, había pasado de una sociedad pétrea en sus formas a otra más abierta y menos apegada al sentido jerárquico en la organización social. Como dice Maravall, "América proporcionaba unas condiciones óptimas para el impulso reformista del hombre moderno". ${ }^{28}$

Matienzo se planteaba como punto prioritario esclarecer la natural inclinación y condición de los indios. Lo hacía partiendo de la teoría aristotélica y

26 James Lockhart, El mundo hispanoperuano. 1532-1560, México, 1982.

27 Steve J. Stern, Los pueblos indígenas del Perú y el desafío de la conquista española, Madrid, 1986.

28 José Antonio Maravall, "La utopía política-religiosa de los franciscanos en la Nueva España”, en Estudios Americanos, I, 2, Sevilla, 1949, p. 191. 
de su propia experiencia. Su examen aparecía condicionado por una determinación conceptual: los indios habían nacido para servir y para aprender oficios mecánicos. Era lo que los españoles no estaban dispuestos a hacer en América. Tenía también un punto de partida: su visión era enteramente comparativa con las formas de vida españolas, sus valores y apetencias, en las cuales procuraba encuadrar la vida del aborigen, sacándolo de su comunidad primitiva. De una parte, cierta descripción de la condición de los indios adoptaba un aire de uniformidad que hace sospechar en el influjo teórico aristotélico. ${ }^{29}$ De otra, cuando se ocupaba en señalar los distintos tipos de indígenas y penetraba en terreno donde volcaba su propia experiencia - tal el lúcido capítulo sobre los yanaconas -, se advierte una fina percepción, acompañada de una franca - y hasta cruda - descripción de la realidad que pasaba ante sus ojos. Recogía entonces algunas críticas, desmenuzándolas con vigoroso realismo.

Sin los indios yanaconas - decía - la república "no se puede conservar". Y agregaba: "Ninguno con verdad podrá decir otra cosa, porque españoles no sirven en esta tierra, ni conviene que sirvan, porque perderían mucha autoridad con los indios [...] ¿Quién es tan mal aventurado que deja su tierra y viene a ésta, pasando tantos mares y tantos peligros por mar y por tierra, por sólo comer y para lo tener sirviese a otro en cosas viles como hacen en España? Ni acá habrá ninguno (si no fuese loco), ni hasta ahora le ha habido, ni habrá" ${ }^{30}$ A mayor abundamiento advertía que el mismo vocablo servir había empezado a adquirir un nuevo matiz semántico, desconocido en la Península: su aplicación a aquellas personas que granjeaban la hacienda de otro. Con esta interesante observación, Matienzo ponía en evidencia que el sentido antes conocido de servir - acompañar y asistir al amo - perdía uso entre los españoles del Nuevo Mundo, reflejando así ese cambio de la situación social.

Conforme lo establecían las disposiciones reales, los indios no debían permanecer ociosos y, por su bien, cabía compelerlos al trabajo. Ahora bien, Matienzo no presentaba esta cuestión como una simple forma de perpetuar la dependencia servil, sino como un medio de introducir a los indios en la economía dineraria que despuntaba en el mundo moderno. Invocando a Aristóteles, sostenía la necesidad de que tuviesen "cosas propias" y se aficio-

30 Ídem, p. 25. 
nasen a las mismas. Consideraba que al darles a cada uno "tierras propias y dinero para sí mismos en pago de su trabajo, para con él comprar carneros de la tierra y ganado de España y otras cosas para sí", se aficionarían a trabajar y entrarían "en policía" ${ }^{31}$ La cuestión era reiterada en diversos pasajes del libro y constituía uno de los ejes de la articulación de la nueva sociedad hispanoindígena, en la que el aborigen - según la idea de nuestro jurista - viviría, evangelizado y congregado, hablando, vistiendo y comiendo como el español, teniendo propiedad privada y dinero fruto de su trabajo en el seno de una economía que le permitiera liberarse de los caciques. De tal modo Matienzo, haciéndose eco de la irrupción del dinero en la economía de su tiempo y de la estimación que despertaba como elemento expansivo de la riqueza, impulsaba al aborigen a desprenderse de su organización comunitaria y de su sujeción política para adoptar los principios del individualismo que potenciaba el Renacimiento. Postura ésta que disentía con la de otros juristas, especialmente Polo de Ondegardo, quien coetáneamente procuraba la persistencia del antiguo régimen comunitario de los indígenas. ${ }^{32}$

Cabe señalar que la destrucción de las primitivas formas económicas prehispánicas en el Perú era entonces un hecho, pues paulatinamente los indios habían sido atraídos hacia la nueva economía dineraria, ya como trabajadores independientes, ya como empresarios. Así lo establece Stern en su estudio monográfico sobre Huamanga, comprobación que está más allá de la confesada simpatía del autor por el nativismo puro.

Mucho más se podría decir sobre este asunto - que Matienzo abordaba con buenos materiales y ricas reflexiones - pero a los efectos que me he propuesto basta la insinuación del tema que acabo de hacer para apreciar una compleja yuxtaposición de realismo, utopía y proyectismo en esta elaboración mental que dominaba partes sustanciales de la obra.

La sociedad hispano-criolla era también objeto de minucioso examen. Puede ser otro de los ejemplos representativos. Matienzo detectaba en el Perú tal grado de movilidad social que sus pautas peninsulares lo inclinaban a ver en ello "muy grande desorden". Advertía que oficiales mecánicos sastres, calceteros, barberos, albéitares, herradores, carpinteros, albañiles y otros - no usaban sus oficios y andaban "hechos caballeros". Propugnaba

31 Ídem, pp. 19-20.

32 Cf. Mario Góngora, El Estado en el Derecho Indiano. Época de fundación. 1492-1570, Santiago de Chile, 1951, pp. 212-216. 
entonces que se les obligase a ejercer su trabajo, pero - en una clara aceptación de esa movilidad - exceptuaba a aquellos que "están ya muy ricos y viven muy bien, como hombres honrados y tienen otros tratos y granjerías en que se ocupan".33

Acaso más interesantes aún son, en este punto, las consideraciones que hacía en torno al mercader, coincidentes con la irrupción en Castilla de esas ideas. Sostenía que su actividad no le excluía de ocupar oficios y honras "cuando la costumbre de la tierra no tiene por vileza la mercaduría y adonde la usa gente noble, como en Venecia y Génova”. Agregaba que en "este Reino nunca se ha tenido la mercaduría por cosa vil”, por lo cual aquellos podían ocupar los oficios de alcalde y de regidor, salvo quien vendiese en persona al menudeo en tienda pública o quien usase oficio mecánico. Pero éstos podían aún ser admitidos, tratándose de pequeñas villas. Tampoco eran, decía, ocupaciones viles ni bajas las del chacarero y agricultor, excepto quien por alquiler trabajase en la chácara. Matienzo, recogiendo los ecos humanistas, dispensaba una estima especial al labrador, encareciendo la conveniencia de que se produjera en la tierra pan y vino, que hubiese ingenios de azúcar y obrajes de paño, que se criase ganado de España y que no faltase leña. ${ }^{34}$

Es preciso apuntar aquí que estas ideas de Matienzo formaban parte de una concepción integral del orden económico de la Monarquía, explicitada de modo claro y sucinto. Consideraba que limitar la relación entre las Indias y Castilla al intercambio de plata y de mercaderías, llevaba a producir de una parte la salida del metal fuera de España, y de otra el encarecimiento de las mercaderías en la propia Península. Postulaba, en cambio, que las Indias tuviesen su propio desenvolvimiento económico, sin perjuicio de recibir complementariamente mercaderías peninsulares, entendiendo que el aumento y conservación de estas provincias enriquecía a ambas partes de la Monarquía. ${ }^{35}$ Dicho esto sin olvidar que para Matienzo "la llave de todo el Reino" era la explotación de la gran riqueza minera de Potosí y Porco principalmente. ${ }^{36}$

33 Matienzo, Gobierno..., cit., p. 348.

34 Ídem, pp. 270-273.

35 Acerca de la importancia del pensamiento de Matienzo en materia económica, véase Oreste Popescu, Aspectos analíticos en la doctrina del justo precio en Juan de Matienzo (1520-1579), Buenos Aires, 1982.

36 Matienzo, Gobierno..., cit., pp. 156-157. 
Es interesante completar el enfoque social de Matienzo con otra referencia. Al ocuparse de los quinientos hombres que habrían de venir de España para poblar la región del Río de la Plata, recomendaba que los más fuesen ciudadanos, mercaderes y labradores. Era también necesario que viniesen caballeros, pero que fuesen "pocos y conocidos", porque éstos - agregaba no se querían dedicar a tratos y labranzas sino a "holgar, jugar y pasear". ${ }^{37} \mathrm{Si}$ a esto unimos el desafecto que Matienzo sentía por el caballero en la función de virrey o gobernador, colegimos que acaso en su mente se esbozaba una nueva sociedad, sin los estamentos ni la inmovilidad de la castellana, aunque manteniendo el esquema social de unos que disfrutaban de bienes y estimacion y de otros que eran llamados a servir. Algo más se puede agregar en esta dirección, reforzando lo dicho desde otro ángulo visual. Sostenía Matienzo que en la provisión de oficios, en la encomienda de indios y en otros aprovechamientos de la tierra debían preferirse a los conquistadores, a los antiguos pobladores del reino casados y a sus descendientes, siendo hábiles para ello, declarando que "no es justo" que quienes residiesen en España gozasen de los tributos de los indios, pues éstos se otorgaban precisamente para la conservación de la tierra. ${ }^{38}$

De tal modo, se configuraba una sociedad hispano-criolla, con tendencia menos jerarquizada que la castellana y sometida a nuevas reglas, en base a las cuales la antaña figura prominente del caballero dejaba su plaza - ¿también su halo? - a encomenderos, letrados, mercaderes y labradores, tal cual era la exigencia social del Nuevo Mundo.

Los ejemplos bien podrían multiplicarse. Sólo voy a agregar brevemente algunas exteriorizaciones de ese proyectismo, tan característico de su obra. Seguramente la más saliente fue la propuesta de trasladar la sede del virrey a la ciudad de Cuzco y de constituir allí, en compañía de dos oidores, que se llamarían adelantados, un tribunal con el nombre de Rota, con atribuciones superiores a las demás audiencias. ${ }^{39}$ Si esta idea no encontró eco y de hecho quedó sólo en el campo de las propuestas de dudosa realización, en cambio fue hasta cierto punto genial su idea de establecer una ruta a España a través del Río de la Plata, poblando la región. ${ }^{40}$ No es fácil establecer la relación

37 Ídem, p. 286.

38 Ídem, pp. 324-326 y 276-277.

39 Ídem, pp. 207-214.

40 Ídem, pp. 278 yss.

62 Capítulo III 
entre esta propuesta y la concreción que tuvo años después, pero igualmente muestra como Matienzo combinaba la experiencia - en este caso procedente de información transmitida - con sus dotes de hombre de gobierno para articular un proyecto de alta conveniencia para la expansión territorial de la Monarquía en regiones que aún no estaban colonizadas.

\section{Postulados ético-morales}

El humanismo español tiene profundas raíces ético-morales, unas de procedencia medieval, otras de origen renacentista. Su parentesco con la Teología renovada del Quinientos puede percibirse por distintos conductos. Es una de sus más nítidas peculiaridades, que lo distingue de otros movimientos análogos europeos. Paradojalmente ha sido con frecuencia argumento para negar la existencia de ese humanismo.

Aunque los juristas permanecieran siempre más atentos a su propia tradición literaria, las nuevas cuestiones que planteaba la realidad americana los llevó a buscar las soluciones más allá de los límites estrictos de su disciplina. Así el recurso al teólogo-jurista o al moralista se hizo inexcusable en ciertas materias. Veamos dos destacadas muestras de esa preocupación en Matienzo.

Cuando se ocupaba de las calidades que debía reunir la persona que gobernase el Perú, Matienzo colocaba en primer término el requisito que fuese "hombre virtuoso; cristiano probado y conocido por tal en su niñez, mocedad y madura edad, y en toda su vida" y que además tuviese "buena fama." ${ }^{41}$ Es todavía más elocuente al respecto el extenso capítulo que consagraba - con nutrido elenco de pensadores clásicos - a la avaricia y a los males que ésta causaba, llevándole a concluir que ninguna persona con ese vicio debía ocupar oficios de gobierno y justicia aunque fuese "más sabio que Platón". 42 Es sugerente esta valoración de la virtud moral sobre el saber en quien pugnaba a favor del gobierno letrado.

El otro ejemplo es aún más representativo de aquella presencia de la moral. Se trata del grave problema de conciencia que suscitaban las nuevas conquistas y descubrimientos, y sobre todo la restitución de bienes por parte de los conquistadores que habían robado o quitado la vida a los indígenas o,

41 Ídem, p. 199.

42 Ídem, pp. 315-320. 
aún más, por parte de los encomenderos que habían abusado de sus naturales. No me propongo tratar aquí tan espinosa cuestión, sino sólo llamar la atención sobre la incorporación de este tema a la obra, acompañada de reflexiones destinadas a encontrar soluciones que atendieran al descargo de conciencia de conquistadores y encomenderos.

En cuanto a la primera parte de la cuestión, la preocupación de Matienzo era recoger y perfeccionar las normas existentes en la materia, en respuesta a las dudas y los escrúpulos suscitados y expuestos en la controversia de los decenios anteriores. Esa preocupación se acentuaba para determinar cómo y a quién se había de hacer la restitución por robos y muertes ocasionados por capitanes y soldados en el curso de sus campañas. La pluma de Matienzo cobraba singular desenvoltura al ocuparse de los bienes que los conquistadores del Perú se habían apropiado en Cajamarca y en Cuzco. En consonancia con otras opiniones doctas, admitía la necesidad de hacer la restitución, destinando los bienes a hospitales de indios, a pobres y a iglesias y monasterios del reino para las rogativas pertinentes. Esta restitución estaba limitada a capitanes y soldados que habían cometido excesos, sin alcanzar al rey, ya que el reino había sido justamente ganado. ${ }^{43}$ Incitaba también Matienzo a los encomenderos que habían llevado bienes o servicios superiores a la tasa, o que hubiesen descuidado sus obligaciones, a hacer alguna restitución en beneficio del común de los indios, en descargo de sus conciencias, restitución que solía emplearse en compra de ganado de la tierra, vacas y ovejas de Castilla. ${ }^{44}$ De tal modo, Matienzo incorporaba al mundo del jurista estas reflexiones ético-morales, dándoles aplicación y contribuyendo a ofrecer fundamentos más sólidos a los preceptos proyectados.

\section{La idea de Derecho}

Pueden hacerse algunas consideraciones en torno a la idea de Derecho que se detecta en el Gobierno del Perú. Esta idea rebasaba ampliamente el mero ordenamiento legal. Eran pocas las citas de textos legislativos del Derecho común y del Derecho castellano. Mayor atención prestaba Matienzo a la normativa indiana, incorporándola en parte a sus propuestas. Pero, como

43 Ídem, pp. 338-347.

44 Ídem, pp. 13, 71 y 347. Sobre otra importante cuestión, los tesoros encontrados en las huacas, véase pp. $12-131$. 
hemos visto, las fuentes utilizadas estaban con frecuencia mucho más allá de las normas propiamente dichas.

El jurista recogía de la tradición medieval la unión entre los derechos civil y canónico. Así, al ocuparse de los obispados, prevenía a sus eventuales críticos que "no me pueden imputar que es meterme en mies ajena, pues nuestra profesión es Derecho Canónico y Civil”. ${ }^{45}$

Formado en una concepción casuista, Matienzo acentuaba el papel del gobernador y del juez en la realización del Derecho. Así daba al visitador de pueblos indígenas amplia facultad para decidir, en la imposibilidad de dar reglas generales "porque en cada tierra se ha de hacer de diversa manera". De igual modo, al que gobernase los asientos mineros de Potosí y Porco había que otorgarle la posibilidad de "suspender la guarda de las ordenanzas que le pareciere que son dañosas a la conservación del asiento, hasta que se comunique con la Audiencia de los Charcas" ${ }^{47}$ De ahí su interés en resaltar la necesidad de elegir ministros prudentes y prevenidos, hombres virtuosos y buenos cristianos, que fuesen además entendidos en las "cosas de república" y con experiencia en "las cosas de la tierra que hubiese de gobernar". ${ }^{\mathbf{4}}$ Invocando a Platón decía que "si el que a la república tiene proveída de leyes no pone buenos y bastantes gobernadores y jueces, aunque las leyes sean buenas, no sólo no aprovecharán y serán cosa de risa, más traerán grandes calamidades y destrucción a la tal república”. Y daba enseguida a la inspiración platónica la contingente aplicación: "Esto se ha por experiencia en este Reino más que en otros" ${ }^{49}$ Matienzo también observaba, de otra parte, el problema de la ejecución de las leyes en el Nuevo Mundo y así en determinada cuestión sostenía que "no basta mandarlo por leyes, sino buscar un ejecutor de ellas" ${ }^{50}$ Por ello ponía énfasis - como vimos - en puntualizar las condiciones ético-morales de gobernadores y jueces. Esta confianza en la intervención decisiva del hombre en la realización del Derecho es propia del pensamiento español de la época.

Matienzo se orientaba hacia un moderado legalismo, como medio de acción de ese "aparato estatal" que estaba en una primera etapa de consoli-

45 Ídem, p. 333.

46 Ídem, pp. 21 y 63.

47 Ídem, p. 157.

48 Ídem, p. 199.

49 Ídem, p. 196.

50 Ídem, p. 314. 
dación y a cuyos fundamentos contribuyó activamente su obra. Era necesario legislar, reglamentar las diversas cuestiones conflictivas, y el punto final de su labor se encaminaba hacia ese objetivo. Pero ello debía ser el resultado de la observación atenta de la realidad, el fruto decantado de la experiencia. Por eso recordaba que los sabios antiguos reprendían a quien al comienzo de su gobierno hacía muchas leyes, mudando las existentes. ${ }^{51} \mathrm{Al}$ respecto Matienzo puntualizaba como precepto para el nuevo gobernante del Perú:

que no entre de presto a mudar las costumbres y hacer nuevas leyes y ordenanzas, hasta conocer muy bien las condiciones y costumbres de los naturales de la tierra y de los españoles que en ella habitan, que como es larga, con muy diversas costumbres, como los temples, y el que está en Lima no puede saber lo que conviene al gobierno de la Sierra, si no es por relación, porque es muy diverso del de los Llanos.

Y agregaba: "Hase primero de acomodar a las costumbres y naturaleza de los que quiere gobernar, y andar a su gusto, hasta que ganada con ellos la opinión y fe, pueda con la autoridad que tiene, y estribando en ella hacerles mudar costumbres, y que haga lo que les mandare." ${ }^{52}$

Las leyes y ordenanzas eran - según Matienzo - el instrumento adecuado para dar orden a las situaciones planteadas. Confiaba pues en la misión ordenadora de la legislación, sobre todo al proponerse una transformación de la comunidad aborigen. De ahí que no hiciese especial cultivo de la costumbre, aunque mostrase interés por la misma y la mantuviese en cuanto fuese necesario. Es sugestivo que, más de una vez, utilizase la expresión "leyes y costumbres" para referirse al conjunto del ordenamiento jurídico. ${ }^{53}$ No había, en cambio, como en Polo de Ondegardo, preocupación por los usos y costumbres indígenas. Su inclinación legalista lo llevó a establecer como conclusión de sus exámenes, conjuntos de preceptos para regular cada materia tratada. Eran las bases de una amplia tarea legislativa en el Perú, que poco después abordaría el virrey Toledo, inspirándose en parte en el libro de Matienzo.

La compleja realidad del Nuevo Mundo y la tradición española del pluralismo jurídico llevó a nuestro jurisconsulto a admitir que cada provincia tuviese sus leyes y costumbres y a considerar - siguiendo a Aristóteles - que

51 Ídem, p. 16.

52 Ídem, p. 201.

53 Ídem, pp. 10 y 314.

66 Capítulo III 
el querer gobernarla de otra manera era causa de levantamientos. Así como el Perú era distinto a Nueva España, de igual modo el gobierno de los indios difería del de los españoles. ${ }^{54}$

La concepción jurídica de Matienzo se completa con el papel que asignaba, dentro de ese nuevo orden, a las audiencias y a los letrados. La audiencia era el órgano de control superior en cada jurisdicción, encargada de la materialización del Derecho y la Justicia. Los oidores - además de integrar el tribunal - estaban llamados a cumplir determinadas tareas en misión individual - visitas, retasas, etc. Por la majestad que dimanaba de su autoridad, era la audiencia el mejor instrumento para "asegurar la tierra" de alborotos y levantamientos. ${ }^{55} \mathrm{~A}$ ella acudían los súbditos quejosos y especialmente los indios vejados. Principal atención prestaba Matienzo, cuando trataba de la organización y del lugar de emplazamiento de las audiencias, a la posibilidad de que pudiesen acudir más fácilmente los indios. Así, en un pasaje, trataba de evitar que los indios de la Sierra debiesen bajar a Lima, y en otro procuraba la mejora de los caminos por donde iban tanto litigantes, como el del Cuzco a la Plata. ${ }^{56}$ Las interesantes consideraciones que hace Stern en torno a la afición del indígena a la justicia española y a los beneficios que de ella obtuvo apoyan esta preocupación de Matienzo. ${ }^{57}$ Según se aprecia, la función de las audiencias estaba encuadrada dentro de su concepción de una justicia real, que realizara el Derecho en los casos concretos.

Esto mismo llevaba a Matienzo a enaltecer la función de los letrados en el gobierno del Reino. Con espíritu inquisitivo y con fuerza humanista planteaba la cuestión de si eran mejores los caballeros o los letrados en el gobierno del Perú. ${ }^{58}$ Daba las razones por las cuales se podía aceptar la primera alternativa - temor y reverencia hacia su autoridad, retribución de servicios, noticia y experiencia en las cosas de Guerra -, para luego manifestar su preferencia por la segunda. Los letrados eran más humildes, menos dispendiosos y más dependientes del rey, cuya autoridad - remarcaba - era la que más importaba resaltar. Los oficios - agregaba - no se otorgaban teniendo en cuenta los servicios prestados por el agraciado o por sus antepasados, sino

54 Ídem, pp. 16 y 314.

55 Ídem, pp. 217-218, 334 y 76.

56 Ídem, pp. 216 y 312.

57 STERN, Los pueblos..., cit., p. 185.

58 Matienzo, Gobierno..., cit., pp. 196-207. 
por las calidades que debía reunir la persona para su desempeño. La experiencia en el Perú, por último, indicaba que los letrados habían gobernado mejor y hasta habían vencido en las batallas, por lo que "en esta tierra parece que Nuestro Señor ha mostrado querer ser gobernada por letrados...” Para Matienzo era objetivo del gobernador conservar "en paz la tierra con sus letras y prudencia”. No obstante, después de ofrecer en toda su exposición una imagen del buen gobernador muy vinculada a las dotes del letrado, terminaba estableciendo como figura modélica, como "luz y espejo de todos los que fueren" al virrey don Antonio de Mendoza. Pero en este caso la exaltación se debía a sus virtudes - proveía en cargos y oficios sólo a los hombre idóneos - y no por tratarse de un caballero de alcurnia.

Dentro de este extenso capítulo - el primero de la segunda parte -, en donde pueden apreciarse rasgos humanistas en estilo literario, reflexiones críticas e invocaciones de autores, se destaca el contrapunto caballero-letrado, así como la cuidadosa caracterización del oficio, sustentados ambos en una concepción de la Monarquía, cuyo nervio estaba en ese aparato burocrático constituido por los oficios y dirigido por letrados.

\section{Epílogo}

El terreno está aun poco labrado para confiar en la fuerza intelectual de unas conclusiones afirmativas. $\mathrm{Ni}$ el humanismo jurídico es asunto hoy precisamente definido, ni el mismo concepto de Renacimiento goza de uniforme opinión. He establecido mi modesta pretensión: abrir cauces en el estudio de una vía del humanismo jurídico - o "humanismo racionalista", según Carpintero - poco atendida en la investigación hispánica y menos cultivada aun en el campo americanista.

Según hemos comprobado, el Gobierno del Perú no contiene ideas novedosas con respecto a otros escritos españoles o coetáneos. Coincido en este punto con Stern, quien sostiene que la originalidad de Matienzo residía en su capacidad para conceptualizar esas ideas como parte de un proyecto articulado, destinado a ofrecer una reforma decisiva en el ordenamiento peruano. ${ }^{59}$ Pero estimo que es necesario destacar algo más en cuanto se trata de una obra jurídica. Al mencionarse el despliegue renacentista en los diver- 
sos campos intelectuales suele omitirse casi siempre la esfera del Derecho. Sin perjuicio de que puedan señalarse otros ejemplos - anteriores y posteriores a Matienzo - estimo que estamos en presencia de una nítida exteriorización de un humanismo jurídico renacentista. Se trata de una concepción peculiar, estrechamente relacionada con los problemas que suscitaba el Nuevo Mundo y por lo tanto diferente a la que se difundía por el continente europeo. Aunque Matienzo llegó al Perú cuando ya tenía 41 años de edad y llevaba una formación clásica de letrado, pudo componer un nuevo tipo de obra como resultado de la observación crítica de la realidad y del estímulo de un saber humanista. Impera en sus páginas un amplio conocimiento de la sociedad, la economía, y la política de su tiempo y hasta despuntaban ciertos visos de estadista. Partiendo pues de la realidad, sus dotes creativas lo llevaron a proponer una transformación de la sociedad indiana - con dosis de utopia -, sirviéndose para ello libremente del saber de los antiguos. Era un cauce distinto del que seguían aquellos juristas - también humanistas - que en Europa cultivaban con nuevos elementos el Derecho común.

Cabe recordar, en fin, una justa expresión de Lohmann, quien considera a Matienzo como el escritor de mayor levadura jurídica en el siglo XVI indiano. De mi parte, agrego que el Gobierno del Perú es, a mi juicio, la obra-clave para entender una de las vías de ese humanismo jurídico, un humanismo con espíritu renacentista, que empujaba hacia adelante. 



\section{La Víctima Real Legal de Álvarez de Abreu en el pensamiento indiano*}

Sumario: 1. Introducción - 2. El autor y la estructura de la obra - 3. Las fuentes ideológicas - 4. La especialidad del Derecho Indiano - 5. La grandeza de la Monarquía española y el providencialismo político - 6. Los títulos de la conquista de Indias - 7. La imagen del Rey - 8. Significado de algunos vocablos - 9. Epílogo

\section{Introducción}

Cuidadosas lecturas de la Víctima Real Legal de Álvarez de Abreu ${ }^{\mathbf{1}}$ me decidieron a ofrecer este examen de sus ideas fundamentales, más allá de la tesis concreta que sostiene en sus páginas. La ubicación ideológica de esta obra representativa del derecho indiano de la primera mitad del setecientos nos puede auxiliar en el conocimiento del período, aún oscuro en la historia del pensamiento hispánico, que une el Barroco con la Ilustración.

Hoy, acaso más por intuición que por una completa información, suponemos que el paso de uno a otro momento histórico se produjo a través de un lento avance, aunque firme, hacia la modernidad. Pero los interrogantes que se plantean son muchos: hasta qué punto hubo persistencia del pensamiento tradicional o aceptación de los nuevos criterios; hasta dónde se trató de un proceso de madurez hispánica o de presiones ideológicas externas; cuál fue la actitud crítica ante lo existente y cuál la defensa del legado tradicional; y en fin, hasta qué grado se entrecruzaron las nuevas ideas y el antiguo pensamiento.

* Publicado en V Coloquio de Historia Canario-Americana (1982). Excmo. Cabildo Insular de Gran Canaria, Las Palmas, 1985, t. I, pp. 959-983.

1 Antonio Joseph Alvarez de Abreu, Victima Real Legal. Discurso único jurídico-históricopolítico sobre que las Vacantes Mayores y Menores de las Iglesias de las Indias Occidentales pertenecen a la Corona de Castilla y León con pleno y absoluto dominio, Madrid, 1726. Segunda edición, corregida y aumentada por el autor en Madrid, 1769. He utilizado en este trabajo ambas ediciones. En las transcripciones he seguido el texto de la segunda. 
Bajo estas - y otras - motivaciones he realizado repetidas lecturas de aquella obra, buscando extraer los elementos que permitan responder a esas preocupaciones y ubicarla en el pensamiento indiano. Esto implica que al recorrer sus páginas he procurado aprehender el modo de pensar profundo, el íntimo razonamiento, que aflora espontáneamente cuantas veces el autor necesitaba expresarlo para convencer al lector de su novedosa tesis. También acuden en nuestro auxilio las nutridas notas al pie de página, en donde se hace gala de un riquísimo arsenal ideológico que resulta de gran utilidad en la tarea propuesta.

El interés de esta indagación se acrecienta, a mi juicio, si tenemos en cuenta que la obra, por su propia naturaleza, no estaba dirigida a un público general sino a un sector reducido de teólogos, juristas y ministros con el propósito de atraerlos a su tesis, venciendo explicables resistencias. El cumplimiento de este objetivo obligaba seguramente al autor a utilizar, más allá de su propia formación y convicción, las ideas y el lenguaje más adecuado para lograr ese fin, y ese no era otro que el que resultaba más próximo a ese conjunto de personas al que se dirigía. De tal modo, el análisis de esta obra constituye un buen camino para conocer la estimación colectiva de esas décadas más allá del punto de vista de un autor determinado.

El método expuesto, de verificar "el contexto ideológico" a través del examen de una obra monográfica, ofrece la ventaja de penetrar en un pensamiento más espontáneo, pero presenta el peligro de la interpretación forzada, pues el autor no siempre se explayó sobre el tema elegido por nosotros todo lo necesario o, al menos, todo lo apetecido por quienes hacemos la indagación. He tratado por ello de formar un ramillete de temas y palabras claves, que aparezcan bien reflejadas en la obra, que nos permitirán acceder a la cuestión y tentar algunas conclusiones. Acudamos pues a ellos con ese propósito.

\section{El autor y la estructura de la obra}

Antonio José Alvarez de Abreu nació el 7 de febrero de 1688 en la isla de La Palma, en el archipiélago canario. Después de estudiar gramática y filosofía en el convento de San Agustín de La Laguna, se trasladó a la Península, graduándose de bachiller en cánones en la Universidad de Salamanca en 1707. Ya en Madrid, su propia inclinación - como él mismo lo decía - y tal vez, el estímulo que le brindó su protector, don Melchor de Macanaz, lo 
llevaron a profundizar el tema de las regalías. Fue allí, entre 1711 y 1714 , cuando nació el primer esbozo de la obra.

Su primera impresión fue - según lo ha dejado escrito - que la práctica observada entonces en el Consejo de Indias era disconforme con la que surgía de los papeles y libros que, por esos días, consultaba en la Biblioteca Real. En 1714 pasó a Caracas, en misión oficial, desempeñando diversos oficios. Posteriormente, durante 1722 y 1723, fue asesor en La Habana y Veracruz del comisario real de Marina, don Joseph de Campillo. A fines de este último año retornó a la Península, ocupando desde entonces distintos oficios públicos hasta que en 1730 fue promovido al Consejo Real de Indias, como ministro. Murió en $1756 .^{2}$

La Víctima Real Legal esbozada ya antes de 1714, fue continuada y concluida en Caracas, en 1720, cuando el jurista sólo tenía treinta y dos años de edad. Los trámites de la autorización real, el viaje de retorno y posiblemente los últimos ajustes, demoraron la impresión de la obra que se hizo en 1726 en los talleres madrileños de Antonio Marín.

La obra tuvo gran influjo doctrinario durante el siglo XVIII y su autor se convirtió en "primera autoridad"3 Bien pronto la tesis sustentada se proyectó sobre el terreno legislativo, al punto que fue recogida en el decreto real de 20 de septiembre de 1737 , inserto en la real cédula de 5 de octubre de ese año. ${ }^{4}$ Esta influencia directa, indicada muy ligeramente en el texto del decreto, fue expresamente reconocida en la real cédula de 8 de julio de 1738 que otorgó al jurista canario y a sus sucesores un título de Castilla, con la denominación de Marqués de la Regalía. ${ }^{5}$

2 Agustín Millares Carlo y Manuel Hernandez Suarez, Biobibliografía de escritores canarios (siglos XVI, XVII y XVIII), t. I, Valencia, 1975, pp. 91-93. Analola Borges, Alvarez de Abreu y su extraordinaria misión en Indias, Santa Cruz de Tenerife, 1963, pp. 21-31.

3 Alberto de la Hera, "Alvarez de Abreu y la naturaleza jurídica de los diezmos en Indias", en III Congreso del Instituto Internacional de Historia del Derecho Indiano. Actas y estudios, Madrid, 1973, p. 808. Cayetano Bruno lo coloca a la cabeza de los autores regalistas del siglo XVIII (El derecho público de la Iglesia en Indias. Estudio bistórico-jurídico, Salamanca, 1967, p. 144).

4 Su texto en Antonio Muro Orejon, Cedulario americano del siglo XVIII, t. III, Sevilla, 1977, p. 196-204.

5 La real cédula transcripta en Millares Carlo y Hernandez Suarez, Biobibliografía de escritores canarios..., cit., pp. 99-100. 
Alvarez de Abreu no descuidó la obra, una vez impresa. Le hizo correcciones y agregados, ${ }^{6}$ que sólo vieron la luz en la segunda edición impresa en 1769 por Andrés Ortega, en Madrid, varios años después de la muerte de aquél.

Precedida, al uso barroco, de expresivas dedicatorias al Rey y al arzobispo Domingo Valentín Guerra, confesor de la Reina, la obra se dividía en dos artículos, cada uno de los cuales constaba de siete partes y a su vez éstas se subdividían, sucesivamente, en secciones y párrafos, llevando numeración corrida.

En el primer artículo se ocupaba de los derechos de la Corona en las Indias por conquista y concesión pontificia, y particularmente de la donación de los diezmos. ${ }^{7}$ En el segundo, abordaba la tesis principal: la pertenencia a la Corona, en pleno y absoluto dominio, de las vacantes mayores y menores de todos los oficios eclesiásticos de las Indias. ${ }^{8}$

Era preocupación dominante del autor, expresada repetidas veces, cuidar la hilación y proporcionalidad del Discurso, evitando las digresiones innecesarias o el desmesurado abultamiento de las cuestiones. ${ }^{9}$ Era consciente de estar enfrentado a un tema espinoso, en el que se apartaba del común sentir, ${ }^{10}$ debiendo atacar, por una parte, la práctica arraigada del Consejo de Indias y, por otra, la Concordia de Burgos, a la que consideraba apócrifa y nula. ${ }^{11}$ Ello lo llevaba a emplear un cuidadoso método de trabajo y a proceder por partes para vencer la dificultad. ${ }^{12}$ Esto es lo que el jurista canario

6 La portada de la segunda edición reza: “corregida y aumentada por el mismo autor”. No he trabajado en el cotejo de ambas ediciones para conocer la importancia de la tarea realizada en este sentido. He hallado una referencia a "este año de 1735 " (p. 235, nota con asterisco) y otra a una obra impresa en Roma en 1741, para la que se emplea la palabra "novísimamente" (p. 219, nota K). De esto puede deducirse que la corrección fuese tal vez continuada. No he hallado, en cambio, en la obra referencia al Decreto de 1737.

7 Se ocupa del tema de la Hera, “Alvarez Abreu...”, cit., pp. 803-826.

8 Sobre la materia, véase Alberto de la Hera "La regalía de las rentas eclesiásticas vacantes en la doctrina del jurista canario don Antonio Alvarez de Abreu", en II Coloquio de Historia Canario-Americana (1977), t. II, Sevilla, 1979, pp. 225-246. Un suscinto examen de la cuestión en Bruno, cit., pp. 292-295.

9 Víctima Real Legal, núms. 31, 35, 47, 56, 204, 272, 274 y 358.

10 Ídem, núm. 794.

11 Ídem, núm. 533.

12 Ídem, núm. 423 y Dedicatoria. 
denominaba "Systema", ${ }^{13}$ es decir la exposición de suposiciones o hipótesis para que una vez relacionadas, explicasen y probasen la tesis propuesta. ${ }^{\mathbf{1 4}}$

El derecho decimal y el Patronazgo de las Indias aparecían como los presupuestos necesarios para sustentar la tesis principal. Pero también era indispensable desbaratar objeciones y atacar, como he dicho, sólidas autoridades. Vencidas estas dificultades en el Discurso, aquellos dos elementos convergían en la demostración sobre la pertenencia plena y absoluta de las vacantes mayores y menores de todos los oficios eclesiásticos indianos. El producido de estas vacantes, sostenía el autor, convenía utilizarlo en obras pías, es decir en la sustentación de la tarea apostólica en Indias, con lo que quedaban liberados los recursos que a este fin provenían directamente de la Real Hacienda, los cuales podrían ser aplicados a requerimientos seculares. El jurista canario agregaba que, en casos de extrema urgencia para hacer frente a la guerra, el rey podía servirse del fruto de esas vacantes. No dejaba, por último, de insinuar la posibilidad de adoptar algún acuerdo con la Santa Sede en relación a estas cuestiones "a fin de purgar la materia de todo escrúpulo que se quiera suponer". ${ }^{15}$

La obra aparecía envuelta en una concepción y lenguaje barroco, aun cuando se aprecien síntomas de cierta modernidad expresiva, tal como corresponde a un período de transición. El lenguaje del Barroco, oscuro y a veces exuberante, suponía una estimación de la dificultad. Es decir, que el entendimiento sólo quedaba satisfecho y convencido si lograba descubrir lo que estaba debajo de la trama de palabras. Un siglo antes, Góngora se había honrado por "hacerme escuro a los ignorantes, que esa es la distinción de los hombres doctos, hablar de manera que a ellos les parezca griego; pues no se han de dar las piedras preciosas a animales de cerda" ${ }^{\mathbf{1 6}}$

Este juego literario era mucho más pronunciado en el primer título de la obra - como lo veremos después - y en las dedicatorias que la precedían y, en cambio, aparecía más atenuado en el desarrollo del Discurso, que se desenvolvía dentro de una mayor libertad y claridad expositiva.

Acudamos a un expresivo ejemplo que ofrece el primer párrafo de la dedicatoria al arzobispo Guerra, así concebido: "Todos los que han querido

13 Ídem, núms. 142, 379, 397 y 686.

14 Véase Real Academia Española, Diccionario de Autoridades (Madrid, 1726), voz "systema".

15 Víctima Real Legal, núms. 748 y ss. y 746 respectivamente.

16 José María Valverde, El Barroco. Una visión de conjunto, Barcelona, 1980, p. 52. 
probar fortuna, embarcando su ingenio sobre las frágiles tablas de la Prensa en el mar negro de la Imprenta, han pensado precaver los riesgos de tan peligrosa navegación con el patrocinio y protección de sus Mecenas, persuadidos a que la autoridad de la Persona a quien presentan sus literarias fatigas los preservará de aquellas borrascas, con que la sinrazón se arma para combatirlas, aun antes de hacerse a la vela".

La obra estaba consagrada al Rey Felipe V, pero debía llegar a Su Majestad por la mano del Arzobispo. Esta aparente sencilla explicación llevaba al autor a otro intrincado juego literario, en el que se iban mezclando un sinfín de exquisiteces, cumplidos y cuidados que bien vale reproducir tal cual: "No buscando, pues, la mediación de V.S.I. en esta obra para que la ampare con su favor, la honre con su nombre, y defienda con su autoridad, pues todo esto me debo prometer mas e cumplidamente de la poderosa protección de su Majestad, por cuyos derechos, y en honor y gloria de esta Corona, la he trabajado con tanto afán y desvelo; viene a ser ingeniosa traza del profundo reconocimiento que profeso a V.S.I. el buscarle por Mediador y Padrino del Discurso: pues no osando yo ponerle por mi mano a los pies de su Majestad por no padecer aquella conturbación que sensiblemente infunde en los vasallos la presencia del Soberano; he elegido la grata intercesión de V.S.I. para que cubierta con su autoridad esta Víctima, ni se haga despreciable por su Autor en los oídos de su Majestad una materia tan importante y estimable por su objeto, ni carezca de aquel particular mérito que pone en el sacrificio la personal virtud del oferente". ${ }^{\mathbf{1 7}}$

Un lenguaje más directo caracterizaba, en cambio, a todo el Discurso, sin perjuicio de algunos alardes barrocos. La pesadez erudita, y frecuentemente postiza, del Barroco, necesitada de avalar con autoridades cada afirmación, tenía también su manifestación en nuestra obra, aunque se nos ocurre que en este caso la erudición era más auténtica y fruto de un sazonado estudio.

\section{Las fuentes ideológicas}

Un crecido número de obras, de muy variada procedencia y épocas, constituía el nutridísimo arsenal ideológico que daba sólido basamento al libro, conforme con el tan arraigado criterio de autoridad. 
El examen de esas fuentes, mencionadas en la obra con gran despliegue erudito, nos lleva a señalar que las mismas no se apartaban de la tradición hispánica y en su mayor parte eran anteriores al siglo XVIII. Así Alvarez de Abreu se presenta como un típico exponente de lo que Menéndez y Pelayo ha denominado "hispanismo", ${ }^{\mathbf{1 8}}$ con un sabor castizo y con raíces en el propio suelo, aun cuando se tuviera en cuenta, en mayor o en menor medi$\mathrm{da}$, el ejemplo del galicanismo que se desarrollaba del otro lado de los Pirineos. O también, con más precisión, se pudiera hablar de "goticismo", dada la veneración histórica hacia los godos, en cuyo período se echaron los pilares de la tradición nacional, sobre los cuales descansó la doctrina regalista de los siglos XVI y XVII. ${ }^{19}$

Alvarez de Abreu profundizó en esta vertiente sin escaparse de ella. En efecto, de acuerdo a las indicaciones bibliográficas de la obra, no parece contagiado del galicanismo, que por entonces empezaba a penetrar en los ámbitos oficiales e intelectuales de la Península, ${ }^{20}$ ni tampoco de otras influencias foráneas, al menos de modo sensible. Aun cuando por la tesis que propugnaba puede ubicárselo entre los regalistas más radicales, ${ }^{\mathbf{2 1}}$ ese mismo extremismo no puede aplicarse en cuanto a las fuentes ideológicas confesadas, pues éstas en su mayor parte seguían la línea del pensamiento español de los siglos XVI y XVII.

Conforme a lo que era habitual en la literatura barroca, aparecían en la obra de Alvarez de Abreu los más diferentes tipos de fuentes: el Antiguo y Nuevo Testamento, la doctrina de la Iglesia, las colecciones canónicas antiguas y modernas, las compilaciones legales desde las romanas en adelante, los doctores del Derecho Común, los escritores y filósofos del mundo antiguo y desde luego una nutrida literatura europea y española moderna. Entre este abigarrado desfile de autoridades solía, como si fuera una señal de preferencia, distinguir a ciertos autores nacidos en suelo español, llamándolos "nues-

18 Marcelino Menéndez y Pelayo, Historia de los heterodoxos españoles. B.A.C., t. II, Madrid, 1956, p. 432.

19 Sobre esto, ver: Mario Gongora, "Estudios sobre el galicanismo y la "Ilustración Católica" en América Española”, en Revista Chilena de Historia y Geografía, núm. 125, Santiago de Chile, 1957, p. 108.

20 Véase ídem, pp. 109-110.

21 Bruno, El derecho público de la Iglesia en Indias..., cit., p. 144. Juan de Ferreras, Sinopsis histórico-cronológica de España, Madrid, 1700-1727. 
tro Seneca", "nuestro Solórzano", "nuestro político consejero Saavedra Fajardo", etc.

Reforzaré lo dicho con un examen particular de algunas de esas fuentes, eligiendo determinadas materias y haciendo una selección en base a la mayor frecuencia de las citas.

En lo que hace a la historia de España, las obras básicas generales en las que se apoyaba nuestro autor eran las del Padre Mariana ${ }^{22}$ y la casi contemporánea de Juan de Ferreras. ${ }^{23}$ Para el período visigótico utilizaba asiduamente la Corona gótica de Saavedra Fajardo. ${ }^{24}$ También se servía de las obras de Prudencio de Sandoval sobre Alfonso VII y Carlos V, ${ }^{25}$ y en menor proporción de los Anales de la Corona de Aragón de Jerónimo de Zurita ${ }^{26}$ y del Compendio historial de Esteban de Garibay y Zamalloa. ${ }^{27}$ Para las Indias, las preferencias de Alvarez de Abreu se inclinaban hacia la Historia General de Antonio de Herrera ${ }^{28}$ y los Varones ilustres del Nuevo Mundo de Fernando Pizarro y Orellana. ${ }^{29}$ Como se puede apreciar, todas las obras mencionadas, salvo la de Ferreras, pertenecían a la época del Barroco o eran aún anteriores.

Pese a los límites que establece el enfoque monográfico, es posible advertir la presencia de una vasta literatura canónica y civil, tanto de Derecho Común como de España. Así cubrían sus páginas, entre otros, los nombres de Cutello, Moneta, Mostazo, Larrea, Palacios Rubios, Barbosa, Covarrubias, Gregorio López, Lagúnez, Castillo de Bobadilla, Olea, Noguerol, Antúnez, Reifenstuel y Belluga. Especial consideración y frecuentísimas citas merecía la obra de Lorenzo Matheu y Sanz, Tractatus de regimene regni Valentiae..., de la segunda mitad del XVII, la que le servía para establecer una analogía entre este reino y las Indias. De igual modo, otros tres libros aparecían repetidas

22 Juan de Mariana, Historia General de España, Toledo, 1601 (Primera edición en castellano).

23 Juan de Ferreras, Sinopsis histórico-cronológica de España..., cit., Madrid, 1700-1727.

24 Diego de Saavedra Fajardo, Corona gótica, Münster, 1646.

25 Prudencio de Sandoval, Crónica del ínclito Emperador de España, don Alfonso VII, Madrid, 1600; y Historia de la vida y hechos del Emperador Carlos V..., Pamplona, 1614-1618.

26 Zaragoza, 1562-1580.

27 Esteban de Garibay y Zamalloa, Compendio historial de las crónicas y universal historia de todos los reinos de España, Amberes, 1571.

28 Antonio de Herrera, Historia general de los hechos de los castellanos en las Islas y Tierra Firme de mar Oceano, Madrid, 1601-1615.

29 Fernando Pizarro y Orellana, Varones ilustres del Nuevo Mundo, descubridores, conquistadores y pacificadores... de las Indias Occidentales..., Madrid, 1639. 
veces como fundamento de sus opiniones: eran el de Pedro González de Salcedo, De lege política y los de Francisco Salgado de Somoza, De Regia Protectione y Laberynthus creditorum. ${ }^{\mathbf{3 0}}$ Precisamente Menéndez y Pelayo coloca a este último autor a la cabeza de los regalistas españoles, en un papel análogo al de Bousset en Francia. ${ }^{31}$

La teología tradicional seguía brillando en el pensamiento del jurista canario. Con frecuencia mencionaba a Santo Tomás y sus comentaristas. Particular predilección demostraba por la obra del Padre Francisco Suárez, mostrándose admirado con "la piedad, solidez e ingeniosidad que trata todas las materias" ${ }^{32}$ En menor proporción citaba la De justitia et jure de Luis de Molina. Los dominicos Vitoria y Soto eran escasamente invocados. Tan sólo una mención - y no importante - recibían los iusnaturalistas Grocio y Pufendorf.

Entre los juristas indianos, Juan de Solórzano Pereira ocupaba el primer lugar en sus preferencias. Lo consideraba como "perenne manantial de los derechos de Indias" ${ }^{33}$ La Política Indiana era el libro más citado en todo el Discurso y con menor intensidad la versión latina De Indiarum Iure. En varias oportunidades, Alvarez de Abreu manifestaba su respeto y admiración por Solórzano, "nuestro común Maestro, ${ }^{34}$ cuyos trabajos suscitaban "la especial veneración" ${ }^{35}$ y aun lo hacía cuando criticaba sus puntos de vista o doctrina. ${ }^{36}$

Detrás de la Política Indiana, aparecían, numéricamente en gran cantidad, las citas de la obra de Pedro Frasso, De Regio Patronatu Indiarum. En menor proporción también utilizaba el Gobierno Pacífico de fray Gaspar de Villarroel.

Todas estas obras indianas eran del siglo XVII. Las de Solórzano y Frasso superaban en cantidad, largamente, a los demás autores invocados en las páginas del Discurso.

30 Sobre el influjo de este autor, véase Santiago Alonso, El pensamiento regalista de Francisco Salgado de Somoza (1595-1665). Contribución a la historia del regalismo español, Salamanca, 1973, pp. 187-232.

31 Menéndez y Pelayo, Historia de los heterodoxos..., cit., II, pp. 404-405 y 432.

32 Víctima Real Legal, núm. 160.

33 Ídem, núm. 44.

34 Ídem, núm. 321.

35 Ídem, núm. 540.

36 Ídem, núms. 624 yss. 
En cuanto a las obras políticas manejadas, eran numerosas. La más citada, sin duda, las Empresas de Saavedra Fajardo, ${ }^{37}$ buen exponente del Barroco. Tampoco faltaba la mención - aunque muy escasa - de alguna obra moderna, como la del P. Juan de Cabrera, Crisis política, aparecida en 1719, "uno de los textos claves de nuestro pensamiento tradicional". ${ }^{\mathbf{3 8}}$

\section{La especialidad del Derecho Indiano}

La Víctima Real Legal es una obra representativa del derecho indiano, desde distintos ángulos de observación. Su autor había nacido en tierras estrechamente unidas al Nuevo Mundo. Aun cuando sus estudios superiores y la ascendente carrera burocrática lo llevaron lejos del lugar natal, le guardaba un ingenuo amor, al punto que se adhería a quienes sostenían que Colón era canario, confesando que lo hacía simplemente por "la gloria que nos resulta, puesto que el propio suelo, aunque sea pobre y pequeño País, es acreedor a todos los cariños, y es el más poderoso estímulo". ${ }^{39}$ Alvárez de Abreu tuvo además una larga experiencia americana, en cuyas tierras estuvo casi diez años, de los cuales ocho residió en Caracas. ${ }^{40}$ Finalmente, en la Península continuó desempeñando tareas en el gobierno indiano, como Ministro del Consejo Real y Supremo. No puede extrañar pues en el jurista una clara concepción acerca de que el derecho indiano constituía una categoría conceptual distinta del castellano y del canónico común. Esto lo supo comprender y expresar en la obra que examinamos. Veamos.

Como enunciado general de esta idea, podemos apoyarnos en su afirmación de que "hemos de caminar sobre el supuesto de que la sucesión en las Vacantes de Indias no se puede regular por las reglas y derechos generales de los antiguos Cánones, que tienen lugar en donde las cosas están en derecho común; pero no en las Indias, cuyos diezmos, y el Patronato son de Su Majestad, y está inmutado el Derecho Canónico en muchas de sus re-

37 Diego de Saavedra Fajardo, Idea de un Príncipe Político Cristiano. Representada en cien Empresas, Mónaco, 1640.

38 Juan de Cabrera, Crisis política. Determina el más florido imperio y la mejor instrucción de príncipes y ministros, Madrid, 1719.

39 Víctima Real Legal, núm. 8.

40 Ídem, núm. 309, en nota. Sobre esto Borges, Alvarez de Abreu..., cit. 
glas...” ${ }^{41}$ Poco más adelante, volviendo sobre esta idea directriz, decía que "en las Indias no corren las disposiciones Canónicas y Conciliares con la generalidad y extensión que en Europa...."42 Esta idea presidía la obra y aparecía reflejada en distintas ocasiones y con diversos tonos. ${ }^{43}$ Lo indiano era, en suma, distinto tanto por los hechos que lo habían originado como por la normativa aplicable. Había pues una solución indiana, que era la única que él se proponía establecer.

Esto no le impedía naturalmente buscar el apoyo comparativo para esclarecer el asunto. En este sentido, encontraba la analogía en la concesión de los diezmos a los reyes de Valencia y el amparo doctrinario en la citada obra de Lorenzo Matheu. Decía que la concesión de los diezmos a dichos reyes "tiene tal analogía con la de nuestras Indias, que las mismas observaciones hechas hasta ahora sobre la de Valencia, son idénticas para la de las Indias, y con tal simbólica concernencia y consonancia, que el empleo, el fin, las causas, los gravámenes y las demás circunstancias de ambas Concesiones son unos mismos, sin que ni aun el tenor de las Bulas sea diverso" ${ }^{44}$

Tampoco la especialidad de la cuestión era obstáculo para que alentase la idea de que, en base a los mismos fundamentos, se podría hacer extensivo el planteo a las "demás Iglesias patronadas de la Corona de Castilla, en que están concedidas las Décimas con las propias calidades, que en Indias, y reputados, como allí, por meros Administradores los Prelados y Cabildos, y por simples Ministros, los Prebendados y Curas", aunque la falta de información precisa sobre esas Iglesias le impedía ir más allá de una "simple prevención" sobre la cuestión. ${ }^{45}$

En suma, la especialidad del derecho indiano, que debía ser abordado con una información y una óptica distinta al de otras regiones, era concepción vertebral de la obra, pero esa especialidad no implicaba una consideración solitaria de la cuestión, y en prueba de ello trataba de apoyarse en situaciones análogas e inclusive, llegaba a insinuar la posibilidad de extender, si fuesen

41 Ídem, núm. 423.

42 Ídem, núm. 433.

43 Como ejemplos de referencias y aplicaciones de este concepto, véase especialmente ídem, núms. 275, 298, 305, 313, 405-407, 438-439, 445-447, 494, 707-723 y 742.

44 Ídem, núm. 747. Referencias y aplicaciones de esta idea en la Dedicatoria de la obra y en los núms. 42, 366, 456, 465, 468, 619, 644 y 655.

45 Ídem, núm. 747. 
aplicables, los fundamentos expuestos a otras Iglesias de la Corona de Castilla. Esta no era, por cierto, una concepción original, pero representaba una vigorosa afirmación de esa condición del derecho indiano en el siglo XVIII.

\section{La grandeza de la Monarquía española y el providencialismo político}

Como natural sustento de sus tesis, en nuestro jurista no podían faltar breves pero vigorosas páginas dedicadas a exaltar la Monarquía española, describir su grandeza, colocar de relieve su papel de defensora de la religión, y sellar los caracteres épicos de la conquista del Nuevo Mundo. Toda la parte inicial del artículo primero estaba consagrada a estas cuestiones, formando el pórtico argumental de la obra. Está presidida por una concepción providencialista de la política, propia del Barroco hispánico y expresada en párrafos grandilocuentes, también afines al gusto literario de aquel momento histórico.

Empezaba la obra con un exaltado paralelo de las campañas de Julio César y Alejandro con las de los Reyes Católicos, estableciendo una diferencia bien nítida entre ambas. Mientras la conquista de nuevos imperios fue en Alejandro codicia y ambición desmedida, en Fernando e Isabel "sobre ser heroica, y tan propia de sus soberanamente generosos y gallardos espíritus, fue culto devoto, veneración ardiente, y entrañable amor a la Fé, a la Religión y a la Iglesia". Poco después, al referirse en tono laudatorio a las hazañas de los reyes castellanos en la búsqueda de la unidad interna, restablecimiento de la disciplina eclesiástica y expulsión de los mahometanos, agregaba: "Excitados, pues sus Majestades en sus innatos, y Religiosos deseos a la empresa del mayor crédito de su devoción y cristiandad, y estimulados de la honra de Dios en ella, ciegamente promovidos del celo y aumento de la Católica Religión, acometieron la última, y mayor hazaña, el siempre feliz, y nunca esperado descubrimiento, y conquista de las Indias Occidentales...” ${ }^{\mathbf{4 6}}$

Desarrollaba enseguida la tesis providencialista, bajo la idea de un Dios creador que ordena y vigila los negocios del mundo, no sólo en lo individual sino también en el orden de las naciones, favoreciendo o castigando a unas u otras, según sus méritos. 
Así sostenía nuestro autor que el descubrimiento del Nuevo Mundo fue concedido a Castilla por "providencia superior", ya en recompensa por la expulsión de los musulmanes de la Península, ya porque tenía reservada a la Nación Española la labor de evangelizar a aquella porción de la tierra. Luego de reseñar las luchas y perfidias ocurridas en el reino de Castilla antes de la llegada al trono de Isabel, concluía en que "Dios con visible providencia, y como con estudiosa sabiduría, reservaba la heroica Sacramental alianza de entre dos admirables Príncipes para el gobierno de Castilla y León, a fin de que con tal feliz unión lograse nuestra España la gloria incomparable del descubrimiento de las Indias, cediendo esta vasta pero heroica y rica conquista, en recompensa condigna del devoto celo, y religiosa pureza de sus Majestades, y en honor eterno de la Nación, para que rindiendo a la misma venerable Religión los nunca bastantemente ponderados incrementos que reconocemos, fuese inmortal nuestra gratitud a la sabia mano omnipotente". ${ }^{47}$

Alvarez de Abreu encontraba nuevas muestras de esa Divina Providencia en el descubrimiento y conquista al advertir que "para aquella edad estuvo como misteriosamente reservada la producción de un Colón, un Cortés, y los dos Pizarros, todos varones para tan insignes empresas, al parecer mandados hacer, o divinamente asistidos: pues siendo unos sujetos de bien poca experiencia y noticia en las artes de la guerra y policía, practicaron tan militares hazañas, y tan políticos ardides, que merecieron ser registrados sus venturosas empresas en las láminas, y en las Historias con las de sus ilustres contemporáneos el Gran Capitán, los Duques de Parma y Alba, y Marqueses de Pescara, y del Basto, y con las de los demás héroes celebrados en la conquista de Italia y guerra de Africa: sin que antes de aquella Era, ni en los dos siglos que han corrido, se hayan dejado ver iguales Varones, como manifestando la naturaleza haber quedado con su producción cansada, o exhausta" ${ }^{\mathbf{4 8}}$

En fin, consideraba el jurista canario que el descubrimiento y posesión de "tan inmensas, ricas y opulentas Provincias", que habían permanecido ocultas al conocimiento de los hombres, fue un premio que la Divina Providencia quiso dar a España no sólo por haberse establecido en ella los primeros templos cristianos, sino por haber mantenido siempre una fidelidad inquebrantable a la Fé. 
Completaba esta visión providencialista, sirviendo también de natural basamento a la tesis central del libro, la idea de que la Monarquía Española ha sido la gran defensora de la Religión en Europa y la propagadora de la Fe en el Nuevo Mundo atrayendo al culto cristiano "las innumerables Gentes y Naciones, que sin República ni policía, envueltos en costumbres feroces, habitaban aquel vasto y universal Imperio" ${ }^{49}$ España, agregaba, había hecho ese esfuerzo excepcional hasta dejar "despobladas sus ciudades, descubiertas sus fronteras, y hecho infecundos páramos las fértiles campañas de sus dominios". 50

\section{Los títulos de la conquista de Indias}

¿Cuál era la postura del jurista ante el problema de los títulos que justificaban el dominio de la Corona de Castilla sobre las Indias? Aun cuando estuviera fuera de su propósito hacer una exposición integral, Alvarez de Abreu aparecía preocupado por dejar bien resuelta la cuestión, pues constituía uno de los elementos más importantes de su Discurso, ya que esos títulos eran - en su decir - "los ejes sobre que gira toda su armoniosa máquina".

Las páginas dedicadas al tema reflejaban, más bien, la labor de la literatura teológico-jurídica sobre la cuestión, desarrollada durante los siglos XVI y XVII, siendo Solórzano y Vitoria los que - según el jurista canario - se habían ocupado del tema más satisfactoriamente. Alvarez de Abreu abordaba la cuestión, tal como lo había hecho Solórzano, ${ }^{51}$ con un criterio pragmático, es decir reuniendo los diversos títulos que podían alegarse, sin excluir ninguno, y dando a todos ellos una fuerza conjunta, por encima de la valoración particular de cada uno.

$\mathrm{Al}$ examinar los distintos títulos, nuestro autor prefería - "por parecernos más fundado", decía - el derivado del "derecho de las gentes, que en la ocupación, y en el tracto sucesivo de la dominación valora y justifica hasta las que en su principio fueron ilegales" ${ }^{52}$ Ratificaba poco después esta idea al

49 Ídem, núm. 212. En el mismo sentido nº 213-214, 227, 513 y 666-667.

50 Ídem, núm. 220.

51 Sobre esto, véase especialmente F. JAVIER DE AyAla, Ideas politicas de Juan de Solórzano, Sevilla, 1946, pp. 335-342.

52 Víctima Real Legal, núm. 14. 
sostener, con la invocación de ejemplos y autoridades, referidos al derecho decimal, que "el largo tiempo y duración continua es más eficaz que el expreso consentimiento y que justifica por último y hace legítimo el dominio de las cosas, aunque por latrocinio y tiranía se hayan adquirido". 53

La primacía de este título era reiterada en otra ocasión, al decir que los monarcas habían "como descubridores y conquistadores de las Indias, hecho suyas con pleno dominio por el derecho de gentes aquellas tierras, y sus frutos, como País conquistado.... ${ }^{54}$ Y en pleno desarrollo de su tesis, Alvarez de Abreu recordaba que "nuestros Reyes por el derecho de las Armas, y bélica expugnación de aquellas vastas Regiones, se hicieron Señores Soberanos de todas sus tierras y frutos" y en consecuencia "han podido y pueden, como Supremos Legisladores dar a aquel vasto y populoso Dominio la ley que les pareciere". 55

Exaltaba de tal modo este título de conquista que le otorgaba fuerza absoluta. Así afirmaba que "los Señores Reyes Católicos por el hecho de la expugnación bélica, en fuerza del justo título de conquista, y de las Armas, que a costa de sus haciendas, y de la sangre y vida de sus vasallos, emprendieron, se hicieron dueños tan legítimos de aquel dilatado Imperio, que no necesitaban de la Bula del Papa Alejandro VI para justificar su adquisición, y vestirse de la calidad de Supremos Legisladores de los bienes y tierras de aquellas Provincias: pues sólo por acto de mayor veneración y respeto impetraron la gracia y bendición Apostólica...."56

En cuanto al título de donación pontifica, Alvarez de Abreu lo recogía "después del robusto del descubrimiento y conquista" y no lo consideraba, según vimos, necesario para justificar la adquisición. Sin embargo, decía que era "el título más especioso y conspicuo, y que ciertamente creemos de mayor estimación en sus Majestades, como tan reverentes hijos de la Iglesia...”. No penetraba en la justificación de la autoridad con que el Sumo Pontífice pudo hacer esta concesión, pues lo consideraba asunto ya "sobradamente ventilado" y tratado últimamente por Solórzano en su Política Indiana, pero señalaba que estos títulos apostólicos siempre habían sido

53 Ídem, núm. 229. Véase también números siguientes hasta el 253, y especialmente el 247.

54 Ídem, núm. 168.

55 Ídem, núm. 206.

56 Ídem, núm. 514. 
considerados de "calificada autoridad y plenitud" ${ }^{57}$ Pero a ello debía sumarse "los motivos y circunstancias que concurrieron y dieron causa a su expedición”, es decir, "el extender y exaltar en las Provincias bárbaras, gentiles y remotas la Fé, la Religión y el conocimiento del verdadero Dios”, lo cual siempre se ha considerado "la causa más justa, más legítima, más especiosa, y más eficaz para ejercer la Iglesia las más amplias y exuberantes gracias...."58

Alvarez de Abreu no concluía aquí su exposición de los títulos, sino que daba otro paso más, destinado a señalar que los fines de la conquista y la forma en que se había llevado a cabo, afianzaban aquellos títulos originarios. Sobre todo, destacaba que para los reyes era "la publicación y predicación del Evangelio el asunto porque todo se emprendía, y la conversión de los Indios el principal y final intento suyo, a que como objeto de atribución encaminaban directamente sus pensamientos y cuidados...", desvirtuando a los que habían sostenido que "la empresa de las Indias fue en sus Majestades puramente impulso de sus riquezas y sed insaciable de aquel oro, con el afectado pretexto de catolicidad". 59

El encargo, decía, el autor fue tan bien desempeñado por los reyes que "dentro de pocos años comenzaron a florecer en aquellos vastos dominios con admiración propia y confusión de los extraños, la Fé, el culto, la piedad, la justicia, la policía, y todas las demás virtudes, y buenas Artes y con tan admirable progreso, que son hoy la emulación implacable de los Herejes, el honor eterno de nuestra Nación, la apacible felicidad de estos Reynos, el depósito más consistente del estado, el jardín ameno de la Iglesia, y las justas delicias de los pontífices”. Ya en tono francamente apologético, agregaba más adelante: “¿Qué religiosos, qué prudentes y qué entendidos son hoy aquellos habitadores! ¡Cuántos insignes hombres en armas, letras y virtudes heroicas no han producido ya aquellos Países! ¡Qué adelantado no se ve en sus Regiones el culto Divino y la política Española!". 60

Según hemos podido apreciar, apoyados por estas largas transcripciones, Alvarez de Abreu asignaba un primer rango al título derivado del descubrimiento y conquista. Este era el que otorgaba a los reyes una fuerza absoluta,

57 Ídem, núms. 15, 19, 20 y 24.

58 Ídem, núm. 24. Véase también núms. 25-31.

59 Ídem, núms. 32 y 35.

60 Ídem, núms. 23 y 33. Ofrecía además datos de la organización eclesiástica y secular, con cifras correspondientes a 1644 y 1645 (ídem, núm. 34). 
tan absoluta que no necesitaba de ningún otro, ni siquiera de la donación pontificia. Contribuía, sin duda, a cimentar la solidez de este título la creencia en que estas tierras habían sido otorgadas a la Corona de Castilla por designio providencial.

Cuidaba el jurista canario de no hacer una exagerada valoración del título de donación pontificia. Aun cuando reconocía la alta autoridad que poseía, se encargaba de puntualizar, antes que nada, los motivos y circunstancias que habían llevado a la concesión, para que no se interpretara ésta como un mero acto gracioso del Pontífice.

Por último, ponía énfasis en destacar la forma en que los reyes habían ejercido la dominación y gobierno del Nuevo Mundo, tanto en la predicación del Evangelio como en la ordenación política de esas regiones, lo que venía a afianzar aquellos títulos. De tal modo, dicha cuestión no aparecía resuelta por el predominio de uno sobre otro título, sino por el adecuado engarce entre todos ellos.

\section{La imagen del Rey}

La imagen del rey que ofrece la obra de Alvarez de Abreu estaba compuesta de facetas heterogéneas, proporcionadas al objetivo específico del Discurso, pero difíciles de reunir en un conjunto armónico. Con todo, parece útil examinar las más destacadas.

En la portada de la obra se expresaba que el autor "consagróla a la augusta, soberana y católica Majestad del Rey Nuestro Señor don Felipe Quinto”. El empleo del vocablo consagrar nos acerca al mundo de lo divino. Esta presunción aparece confirmada si advertimos que la primera denominación de la obra - Víctima Real Legal - tenía el sentido de un sacrificio, que se depositaba en "las Augustas Aras de V. Magestad", haciéndolo "por mano" del Arzobispo y confesor de la reina. Sin olvidar, en fin, que el objeto de la obra era - según el autor - reponer en la Diadema Real "la piedra de más precio y de mayores fondos, que la adornaba" ${ }^{\mathbf{1}}$

Esta imagen sacra del rey no era mera retórica sino que respondía a un pensamiento más profundo sobre su oficio, que asomaba cuando el jurista abordaba lo relativo al poder de los reyes en asuntos espirituales, cuestión

61 Ídem, Dedicatoria. Este mismo concepto de "la piedra más preciosa" o la "mejor piedra", se reiteraba con relación al Patronazgo (núm. 268) y al derecho decimal (núm. 644). 
que naturalmente aparecía envuelta en las argumentaciones utilizadas en la demostración de su tesis.

Los reyes de España, decía, a imitación de los emperadores romanos, han ejercido, desde los godos, autoridad en las cosas espirituales y ritos eclesiásticos. Ello dimanaba de las leyes y concilios de la Iglesia antigua y de la posesión continua, sin contradicción "a vista ciencia y paciencia del Romano Pontífice." A la luz de numerosos ejemplos, consideraba el autor que ésta era la "inconcusa tradición". 22

Por estos títulos y por la defensa de la Iglesia encomendada por Dios a los reyes - agregaba - "los Príncipes de la tierra tienen dentro de la Iglesia potestad eminente para fortalecer la disciplina eclesiástica, y aun para ordenar las cosas de la Divina Religión”. Esta afirmación aparecía en el texto avalada por un selecto conjunto de autoridades, entre las que sobresalían San Isidoro, San Agustín y una ley de Partidas. ${ }^{63}$

Agregaba Alvarez de Abreu que en Indias, los reyes, por concesión apostólica, "ejercen la eclesiástica y espiritual gobernación de aquellos Reinos, así entre Seculares, como entre Regulares, con plenaria potestad para disponer todo aquello que les pareciere más conforme y seguro en el espiritual gobierno, en orden a conseguir, ampliar, establecer, y promover la Religión Católica, y el aumento espiritual de los Fieles, y conversión de los Infieles que habitan en ellas". ${ }^{64}$ Como afirmaba en otro pasaje, en el Nuevo Mundo el Papa "ha descargado en sus Majestades todo su oficio Pastoral, invistiéndolos de su suprema autoridad", cargando sobre sus hombros el peso del gobierno espiritual. $^{65}$

Esa delegación pontificia, sostenía, no hizo otra cosa que poner en ejecución "aquella compartición de la Regencia espiritual", pues antes que se le concediera el Vicariato de las Indias, los reyes "tenían por Divino Instituto el venerado carácter de Vice-Dioses de la tierra; no sólo en cuanto al gobierno temporal, sino también para el espiritual por lo respectivo a las tierras conquistadas a Infieles, como lo fueron las de Indias" ${ }^{\mathbf{6 6}}$

62 Ídem, núms. 122, y 64 a 121, respectivamente.

63 Ídem, núm. 123.

64 Ídem, núm. 137.

65 Ídem, núm. 310. También en 138.

66 Ídem, núms. 140-141. 
El rey pues tenía y ejercía "la alta protección de todas las Iglesias Catedrales, Colegiales y Abaciales de sus Dominios, sus Prelados y Beneficiados, y es Patrono universal y absoluto de ellos”, estando encargado de la percepción de estos bienes por medio de sus oficiales, debiendo dar cuenta a Dios de "la cura de las cosas Patronadas". ${ }^{67}$ Su obligación, agregaba más adelante, era "remover los abusos e infracciones que vulneren sus derechos y la puntual observancia de los Cánones", pues de no ser así "no desempeñaría todo el misterioso cargo de Rey, ni aun el de Vicario de Dios".68

Si nos fijamos en la extensión del poder real, y sobre todo, en ciertas expresiones sacras, como la de "Vice-Dios", la de dar cuenta a Dios, la de "misterioso cargo de rey" o la de "Vicario de Dios", nos sentimos muy próximos a las doctrinas que se desenvolvían ya por entonces acerca del carácter divino de la realeza, aunque en nuestro caso las afirmaciones de Alvarez de Abreu procuraban apoyarse en autoridades y textos antiguos y modernos, no ajenos a la tradición hispánica. Sin embargo, se apreciaba una tenue penetración del galicanismo, a través de la obra del moderado Pedro de Marca, De concordia Sacerdotii et Imperii, del siglo XVII. ${ }^{69}$

Ahora bien, las vicisitudes de su tesis llevaron también a Alvarez de Abreu a mostrar una faceta distinta del poder absoluto del rey. En efecto, al intentar demostrar la nulidad de la Concordia de Burgos, el jurista canario impugnó las circunstancias y facultades del rey Fernando para celebrarla.

Con tal motivo, decía que un acto tan grave, como la enajenación de una regalía y derecho tan prominente de la Corona "no pudo otorgarse sin el diligente maduro acuerdo y común voto de los de sus Consejos, examen y ponderación de las causas de nulidad o necesidad, que a ello obligaban, y el asenso de las Cortes, todas solemnidades indispensables, y de forma, por las Leyes de Castilla: mayormente cuando no consta que al Señor Rey Católico le obligase a ello alguna causa grave y justa, o que hubiese querido usar en este acto de aquel supremo derecho Monárquico, con que se eximen los Soberanos que le fundan, de estas necesarias formalidades, ni pudiera su Majestad presuponerlo, no siendo entonces Rey de Castilla, sino solamente Gobernador de estos Reynos" ${ }^{70}$ Más adelante insistía en que para proceder

67 Ídem, núms. 275-276.

68 Ídem, núm. 288. En el mismo sentido, núms. 289 y 298.

69 Véase Gongora, Estudios sobre el galicanismo..., cit., pp. 105-106.

70 Víctima Real Legal, núm. 565. 
ajustadamente en estos negocios debía solicitarse "el maduro y prudente juicio de Teólogos, Juristas y Ministros de la mayor satisfacción y experiencia." ${ }^{71}$

El autor afirmaba que este derecho decimal, incorporado a la Corona, y que constituía "la mejor piedra que la adornaba", no podía ser quitado por mera decisión del príncipe, pues "habiendo su Majestad jurado al tiempo de su Coronación, y exaltación al Trono, este juramento antecedente, y tan solemne, y en presencia de los Estados del Reino, hacen injusto e ineficaz otro cualquiera, y por la fuerza del pacto y estipulación con que fueron admitidos, jurados y coronados, de mantener y conservar el Estado, y todos sus derechos, fueros y preminencias, se hace totalmente inalterable; porque siendo calidad inseparable de la Corona por derecho del Reino, la reconocen al ceñirla". ${ }^{72}$

En base a estos y otros argumentos, sostenía la nulidad de la Concordia, criticando duramente la actitud de Fernando el Católico, al acusarlo de mirar "con desamor las cosas de Castilla, y con mayor las de Indias, por haber sido de aquella Majestad [la reina Isabel], y de esta Nación solamente, la gloria de su descubrimiento y conquista". ${ }^{73}$

Envuelta pues en una argumentación particular y compleja, el jurista desarrollaba en esta ocasión una concepción limitada del poder real, cuyos mejores fundamentos doctrinarios y legales encontraba en la propia tradición hispana.

\section{Significado de algunos vocablos}

Me ocuparé, por último, de mostrar el significado con que el autor empleaba algunos vocablos que, a mi juicio, tienen valor decisivo para conocer el clima ideológico que envolvía la obra. Se trata en este caso de palabras utilizadas con cierta reiteración y despreocupadamente dentro de la argumentación de la tesis, en una acepción que el escritor daba por aceptada entre sus posibles lectores.

Dos de esos vocablos - autoridad y novedad - fueron, sin embargo, objeto de un especial tratamiento en la Prefación apologética del Discurso, escrito de

71 Ídem, núm. 570.

72 Ídem, núms. 644-645. Se apoyaba en ejemplos, referidos de núms. 646 a 650.

73 Ídem, núm. 608. Véase núms. 609-611.

$90 \quad$ Capítulo IV 
24 páginas que el autor redactó, según parece, después de terminada la obra. En efecto, Alvarez de Abreu debió tomar la pluma cuando advirtió que su tesis, por apartarse de la doctrina de Solórzano causaba desagrado en algunos Ministros. Es indudable que esta Prefación tuvo sólo esta finalidad, pues fue suprimida en la segunda edición, que el autor había dejado preparada. Sin embargo, estas páginas de circunstancias encierran una apreciable riqueza desde el punto de vista ideológico, ya que el autor se vio obligado a acentuar la impugnación contra el criterio de autoridad y a justificar plenamente la innovación, la novedad, como condición necesaria para el progreso humano. ${ }^{74}$

Fijemos en primer término nuestra atención sobre la voz autoridad, utilizada como fundamento de una opinión o decisión. El criterio de autoridad había llegado a adquirir tal hegemonía que, para algunos, no sólo servía de apoyo para cualquier ejercicio discursivo, sino que tenía valor absoluto. En las últimas décadas del XVII y primeras del XVIII ese criterio, aislado de toda comprobación experimental o racional, aparecía en franca decadencia. ${ }^{75}$

La Víctima Real Legal no escapaba a ese mundo de "autoridades", que acudían en tropel no sólo para apoyar las múltiples cuestiones que se ofrecían a lo largo de la obra, sino aun para fundar nuevos puntos de vista, opuestos a una parte de aquellas "autoridades". Esta exuberancia de recursos eruditos constituía una prolongación de la mentalidad del Barroco.

Pero al mismo tiempo descubrimos en algunas expresiones del Discurso una postura de franco desapego del criterio de autoridad, como cuando decía "estamos en un siglo tan crítico, que ya no se afianzan los discursos con solo la autoridad, por más venerable que sea, ${ }^{76}$ o cuando expresaba que era "especie de filosófica idolatría” ceder a una opinión por el solo argumento de autoridad. ${ }^{77}$

Precisamente Alvarez de Abreu, envuelto en el mundo de las "autoridades", debía explicar cómo se apartaba de ellas al introducir su novedosa tesis. De ahí que en la propia dedicatoria al rey dijera que "la siempre venerable

74 Agradezco al doctor José M. Mariluz Urquijo que me haya facilitado el ejemplar de la primera edición de la obra, así como su oportuna indicación acerca de la existencia de esta valiosa Prefación.

75 Véase Francisco Puy, El pensamiento tradicional en la España del siglo XVIII (1700-1760), Madrid, 1966, pp. 44-45.

76 Víctima Real Legal, núm. 549 y Dedicatoria.

77 Ídem, núm. 323. 
autoridad del Consejero don Juan de Solórzano parecía que había cerrado la puerta a todos los discursos sobre este asunto". Pero, apoyándose en diversas autoridades, agregaba que en el campo del conocimiento nada quedaba definitivamente concluido y firme, y así el mundo reservaba siempre a las nuevas edades "la invención de muchas conclusiones y verdades" ${ }^{\text {78 }}$ Acudía entonces a una alegoría ya utilizada por los renacentistas para demostrar la superioridad sobre los antiguos y así decía que "no es desmedro de la grandeza de un Gigante, antes sí crédito mayor de su eminencia, el que un Pigmeo puesto sobre sus hombres, alcance a registrar más que el mismo Gigante sobre el que se eleva”.

Era en la Prefación donde reiteraba y profundizaba estas mismas ideas. Insistía entonces en que atenerse sólo a la "canosa antigüedad" o a "la multiplicada autoridad de los Doctores" era insuficiente, si no estaba asistida por la razón y consolidada por fundamentos. Conformarse tan sólo con el argumento de autoridad era una servidumbre del intelecto. En fin, a la vuelta de otras consideraciones, afirmaba que en las ciencias humanas - dejando a salvo la Religión - la verdadera autoridad descansaba en "los principios intrínsecos de la razón y del fundamento". ${ }^{79}$ Para arribar a estas conclusiones, Alvarez de Abreu hacía un ingente acopio de "autoridades", que desde la antigüedad clásica llegaban hasta las propias leyes de Indias. No faltaban en sus explanaciones las citas de la Sagrada Escritura, los Santos Padres, los concilios, Justiniano y un sinfín de autores más modernos.

Como vemos, aun en el asomo de una actitud que tendía a dejar de lado el mero criterio de autoridad, aparecía ésta encaramada en la propia solución. Es decir, que todavía era muy fuerte el arraigo del Barroco, aun cuando los síntomas del despegue hacia delante permitían avizorar la aparición de una concepción renovadora. En nuestro escritor estos síntomas surgían especialmente cuando se apartaba en puntos sustanciales de la doctrina de Solórzano y cuando formulaba una crítica histórica y jurídica a la Concordia de Burgos. ${ }^{80}$

Novedad es otra voz adecuada para sondar un modo de pensar. Mientras el Barroco, en una actitud conservadora, solía ver en "la novedad" un peligro en acecho, en cambio la Ilustración, en una postura renovadora, no mostra-

78 Sobre esta idea, véase ídem, núm. 794.

79 Prefación, núms. 12, 24, 25 y 41.

80 Víctima Real Legal, núms. 564, 580, ss. y 624.

92 Capítulo IV 
ría esa misma hostilidad hacia un vocablo que, en cierto modo, podía representarla.

Para el hombre del seiscientos el vocablo tenía, predominantemente, una acepción negativa. Se la empleaba para referirse a algo que causa escándalo, extrañeza, que altera de modo peligroso un orden dado. Este sentido lo percibimos en varias frases de Alvarez de Abreu, ${ }^{\mathbf{8 1}}$ que registran así la huella barroca.

También encontramos en el Discurso otra acepción: la novedad, como lo recién discurrido o descubierto, como superación de lo existente. Este matiz ya había sido captado y admitido por el pensamiento barroco. Por ejemplo, Solórzano al dedicar uno de sus Emblemas precisamente a "guardarse de novedades" había admitido que "cuando lo pide el tiempo y la razón, o se considere evidente utilidad" se podía "innovar algo de las leyes y costumbres de los mayores" ${ }^{82}$ Este último sentido cobraba necesariamente fuerza en el jurista canario, pues el objeto de su libro era precisamente alterar la situación doctrinaria y legislativa existente, introduciendo una novedad, tanto en la tesis postulada, como en las razones y pruebas aportadas, pero entendiéndola como algo útil, provechoso. Así, con referencia al asunto tratado en la obra, decía que era difícil "filosofar con novedad y ajustadamente en materias de este tamaño, ${ }^{83}$ o se empeñaba en destacar todo lo nuevo que había en ella. ${ }^{\mathbf{8 4}}$ Para disculparse de las posibles faltas que hubiese cometido, decía, invocando a Séneca, que era "camino nuevo, en que no hace poco quien abre senda, pues facilita los discursos de los venideros" ${ }^{\mathbf{8 5}}$

En la recordada Prefación, la crítica a la autoridad estaba entretejida con el elogio de la novedad. Siempre apoyándose en "nuestro Séneca" sostenía que aunque los predecesores habían hecho mucho por las ciencias, a los siglos venideros les estaba reservado ampliar el conocimiento. De tal modo, justificaba su propósito, basándose en los estudios de los antiguos de abrir moderadamente "nueva senda". La innovación - agregaba - perfecciona al mundo y al fin las opiniones más antiguas, que hoy aparecían tan respetadas, "en

81 Véase ídem, núms. 194, 196, 280, 743, 745, 746, 752 y 793.

82 Juan de Solorzano Pereira, Emblema regio-politicos. Década sexta, Valencia, 1659, pp. 3-46.

83 Víctima Real Legal, núm. 792.

84 Ídem, Dedicatoria y núms. 643, 687 y 794.

85 Ídem, núm. 684. 
algún tiempo fueron nuevas". Por otra parte - continuaba - si las Ciencias y Artes no tuvieran "la licencia de innovar" quedarían aniquiladas. Como prueba palmaria de ello, se apoyaba en numerosos ejemplos para probar cuanto debían cada una de esas disciplinas "de perfección y novedad, a la sucesión de los siglos...”86

Todas estas expresiones están cargadas de un inocultable gusto por la novedad, recogiéndose la impresión de que aun bajo la invocación de autoridades antiguas y modernas, aquella voz destacaba un perfil bastante distinto que el sustentado por el Barroco.

La obra que analizamos ofrecía sólidos sustentos en la tradición, sobre todo en la española, con una continua apreciación del fenómeno histórico. Era un elemento insustituible que arrancaba de los godos y llegaba a los tiempos modernos sin los claroscuros propios del pensamiento de la Ilustración.

Además, esa tradición no se reducía a un nebuloso y misterioso recuerdo sino que debía ser constantemente verificada mediante una labor crítica documental, que apuntaba hacia el desarrollo de un método histórico científico. ${ }^{87}$ Encontramos en Alvarez de Abreu ya un incipiente espíritu de trabajo en esta dirección, desde un primer momento, cuando examinaba en la Biblioteca Real los papeles del Duque de Uzeda y de otros ministros, y sobre todo en su pertinaz gestión para tener a la vista la documentación del Consejo de Indias acerca de las cuestiones planteadas en 1617 y 1635, de la que sólo tenía noticias por lo que decían Solórzano y Frasso. ${ }^{88}$ Esto mismo se patentiza en la ya mencionada Prefación, cuando luego de hacer un encendido elogio de la Historia como disciplina necesaria al jurisconsulto y al ministro, aplaudía a "los eruditos de esta era" que habían deshecho las falsas tradiciones de los antiguos. ${ }^{\mathbf{9 9}}$

En el campo del derecho, la tradición encontraba su expresión en la alta estima que hacía de la costumbre jurídica, invocándola como fundamento principal, o complementario, al ocuparse de los derechos de la Corona sobre los diezmos y los frutos de las vacantes eclesiásticas ${ }^{\mathbf{9 0}}$ y en la valoración que

86 Prefación, núms. 6, 17, 37 y especialmente 38 en adelante.

87 Puy, El pensamiento tradicional..., cit., pp. 40-41.

88 Sobre esto véase Víctima Real Legal, núm. 144 y nota 1.

89 Prefación, núms. 57 y 48.

90 Véase Víctima Real Legal, núms. 252, 256, 278, 280, 281, 283 y 660-664. 
hacía de los antiguos cánones, a partir de los godos, cuya conservación o restablecimiento propugnaba en algunos pasajes. ${ }^{91}$

\section{Epílogo}

Ha llegado el momento de hacer nuestro balance final. Desde ya descartamos toda pretensión de extraer conclusiones espectaculares o de ofrecer afirmaciones absolutas, ya que el terreno se presenta poco sólido para ello. Pero eso sí, aunque parezca demasiado obvio - acaso perogrullesco - decirlo, cabe sostener que nuestro autor no puede ser encasillado ni en el Barroco ni en la Ilustración, no es ni un puro tradicionalista ni tampoco un innovador.

Pertenece Alvarez de Abreu - y él lo representa bien - a un momento de transición, en el que se manifiesta un proceso ideológico de maduración propia, asentado en gran parte sobre el sustrato tradicional y escasamente deudor del flujo de ideas foráneas. ${ }^{\mathbf{9 2}}$ Así lo indican las fuentes bibliográficas y las autoridades que nutren sus páginas. Como se comprenderá, no es posible pronunciarse en última instancia acerca de si esas menciones reflejaban las convicciones del autor o si, en cambio, eran un hábil modo de encubrir la penetración de ideas o posturas nuevas, para enervar los mecanismos de resistencia social. ${ }^{93}$ Cualquiera fuese la respuesta que se quiera dar, lo cierto es que nos afirma la vigencia, en la sociedad peninsular e indiana, de aquel pensamiento.

Estimo empero que el sustrato tradicional estaba sólidamente arraigado en el autor. Veamos. La obra tenía una estructura, concepción y lenguaje barroco. Sus principales puntos de apoyo argumental residían en la grandeza de la Monarquía española, en la continuidad de la cosmovisión providencialista, en la potestad del príncipe en los negocios espirituales y eclesiásticos y en la afirmación de los títulos de descubrimiento, conquista, dominación y gobierno como los de mayor fuerza con relación a las Indias, sin desechar, pero sin exaltar, el valor del emergente de la donación pontificia.

Junto a estos rasgos característicos del pensamiento tradicional encontramos otros provenientes de una línea renovadora. Así las estrechas relaciones

91 Ídem, núms. 128, 293 y 294.

92 Es la idea central de la obra de Puy. Véase especialmente pp. 129 y ss.

93 O como dice PuY: "la alusión constante al pasado, para renovar posturas" (El pensamiento tradicional..., cit., 68). 
con los altos círculos políticos, el mecenazgo que sobre él ejerció don Melchor de Macanaz y sobre todo, el cariz radical de su tesis, colocan a Alvarez de Abreu entre los más típicos representantes del regalismo hispánico durante el setecientos. Este regalismo avanzado, sin embargo, no le impedía considerarse como "hijo muy rendido de la Iglesia" y manifestar su sometimiento a lo que ella dispusiera con relación a "todas nuestras obras y pensamientos". ${ }^{94}$

Además, había penetrado en el jurista canario la determinación de no aceptar sin examen crítico la tradición ni el criterio de autoridad, lo que muestra otra faceta de su saliente modernidad. ${ }^{95}$

Encontramos pues en Alvarez de Abreu un entrecruzamiento de líneas ideológicas, unas tradicionales, otras decididamente modernas, plenas de matices y tonos, pues era - permítaseme la anfibología - un tradicionalista crítico y un modernista tradicional, según fuese el ángulo del enfoque. Así junto a una concepción apologética de la Monarquía iluminada por el Barroco, se introducía, sin mayores sobresaltos, una postura crítica, empujada por el racionalismo. Creo haber puesto en descubierto este contraste más claramente al examinar el uso de dos expresivas voces - autoridad y novedad -, en este caso con una clara superioridad de sus sentidos modernos sobre todo en la Prefación. La lista de contrastes podría ampliarse con otros temas o problemas. En esta materia y en lo que respecta a nuestro jurista cabe aplicar lo que, en forma general para todo el pensamiento de la época, sostiene un estudioso cuando afirma que "las ideas aparecen muy mezcladas, no ya dentro de los autores, sino aun dentro de la obra concreta, según que sobre cada problema predomine subconscientemente la solución del pasado o la innovadora".96

94 Víctima Real Legal, núm. 793.

95 Sobre el origen cartesiano de la actitud de no inclinarse ante ninguna autoridad, véase Puy, El pensamiento tradicional..., cit., pp. 85-86.

96 PuY, El pensamiento tradicional..., cit., pp. 45-46.

96 Capítulo IV 


\section{La doctrina de los autores como fuente del Derecho castellano-indiano*}

Sumario: I. Aproximación al tema - II. Juristas, sociedad y poder político - 1. Opiniones y obras jurisprudenciales, ¿creadoras de Derecho? 2. Opiniones y opiniones comunes. La auctoritas, como sustento - 3. El saber de los juristas: peso social e influjo político - 4. En torno a las "leyes de citas" - III. Vigencia de los autores en los siglos XVI y XVII. Surgimiento de la crítica - 1. Los autores en las aulas y en los tribunales 2. Opiniones y autores bajo la lupa crítica de profanos y letrados - IV. Siglo XVIII: virulencia de la crítica y subsistencia de opiniones y autores - 1. Una ideología antijurisprudencial -2 . Otras expresiones y matices de la crítica antijurisprudencial 3. Los autores en la actividad de abogados y jueces -4 . Hacia una creación jurídica sin opiniones ni autores - V. Los libros con auctoritas, fijadores de la jurisprudencia castellano-indiana - VI. Consideraciones finales

\section{Aproximación al tema}

Ocupado desde hace algún tiempo en indagar los modos de creación del Derecho indiano, reiteradamente me he preguntado sobre la función desempeñada por la doctrina de los autores. ¿Tuvo rango de fuente directa? ¿Alcanzó fuerza obligatoria por sí, sin recibirla de otra fuente? ¿Qué grado de acatamiento gozó en la sociedad? Después de haber examinado concretamente el punto, basándome en un conjunto significativo de testimonios, considero que la doctrina de los autores tuvo una función - clave en la estructura jurídica de los siglos XVI a XVIII, período que es objeto de nuestro estudio. Dentro de la jurisprudencia casuista, dominante entonces, en la cual los casos o situaciones eran examinados a la luz de su propia peculiaridad, la doctrina era el depósito del saber jurídico, en donde se encontraban los elementos para apoyar la decisión.

Mi intención pues no se limita a determinar, bajo la óptica dogmática, si le cabía o no un papel supletorio en el orden legal, para cubrir eventuales vacíos del ordenamiento. Va mucho más allá y tiende a presentar una pieza

* Publicado en Revista de Historia del Derecho, núm. 17, Instituto de Investigaciones de Historia del Derecho, Buenos Aires, 1989, pp. 351-408. 
fundamental de aquella estructura jurídica. En consecuencia, se podrá comprender su arraigo, aun bajo la persistente crítica. Pero, eso sí, aquella intención no quedará enteramente plasmada en el presente estudio. Es preciso suscitar otros exámenes y debates en torno a esta cuestión. Me limito pues a ofrecer mi aporte desde una postura estimulante para esas nuevas y necesarias contribuciones.

La función de la doctrina de los autores como creadora de derecho no ha sido abordada - según creo - por estudio específico alguno dentro de nuestra historiografía. De la doctrina en sí se han ocupado los trabajos relativos a la ciencia jurídica ${ }^{1}$ y a las fuentes del derecho, ${ }^{2}$ como también las obras de conjunto. ${ }^{3}$ Algunos estudiosos han destacado la importancia que ella tuvo

1 Román Riaza, Historia de la literatura jurídica española. Notas de un curso, Madrid, 1930; Ismáel Sánchez Bella, "Los comentarios a las Leyes de Indias”, en Anuario de Historia del Derecho Español (en adelante: AHDE), t. XXIV, Madrid, 1954, pp. 381-541; RAFAeL Gibert, Ciencia jurídica española. Sumario de un curso, Granada, 1971; Alfonso GarcíaGallo, "La ciencia jurídica en la formación del derecho hispanoamericano en los siglos XVI a XVIII", en AHDE, XLIV, 1974, pp. 157-200. Otros estudios abarcan períodos más reducidos: Román Riaza, El derecho romano y el derecho nacional en Castilla durante el siglo XVIII, Madrid, 1929; Juan Beneyto Pérez, "La ciencia del derecho en la España de los Reyes Católicos”, en Revista General de Legislación y Jurisprudencia, t. 194, Madrid, 1953, pp. 563-581; Javier Malagón Barceló, La literatura jurídica española del siglo de oro en la Nueva España. Notas para su estudio, México, 1959; Bernardino Bravo Lira, "La literatura jurídica indiana en el Barroco", en Revista de Estudios Histórico-Jurídicos (en adelante, $R E H J)$, núm. X, Valparaíso, 1985, pp. 227-268.

2 Ricardo Zorraquín Becú, "Las fuentes del derecho argentino (siglos XVI a XX)", en Revista de Historia del Derecho (en adelante: RHD), núm. 1, Buenos Aires, 1973, pp. 319 y 331; y del mismo autor, "El sistema de fuentes en el Derecho Indiano", en Anuario Histórico-Jurídico Ecuatoriano, t. VI, Quito, 1980, pp. 3-51. También Jesús LaLinde Abadía, "La creación del derecho entre los españoles", en AHDE, XXXVI, 1969, 301-348.

3 Ricardo Levene, Introducción a la historia del derecho indiano, Buenos Aires, 1924, pp. 29-52 y 335-342; José M. Ots CApdequí, Manual de Historia del derecho español en las Indias y del derecho propiamente indiano, Buenos Aires, 1945, pp. 329 y ss. y 345-350; Ricardo Levene, Historia del derecho argentino, t. I, Buenos Aires, 1945, pp. 262 y 353-354; Alfonso García Gallo, Manual de Historia del derecho español, t. I, $2^{\mathrm{a}}$ edición, Madrid, 1964, pp. 220-226 y 398-400; Ricardo Zorraquín Becú, Historia del derecho argentino, t. I, Buenos Aires, 1966, pp. 243-244 y 250; Jaime Eyzaguirre, Historia del Derecho (1967), $5^{\text {a }}$ edición, Santiago de Chile, 1980, pp.103-104, 118, 120, 152, 161-165; Rafael Gibert, Historia general del derecho español, Granada, 1968, pp. 57, 62, 260-262; José M. Ots Capdequí, Historia del derecho español en América y del derecho indiano, Madrid, 1968, pp. 91 y ss. Jesús LaLinde Abadía, Iniciación histórica al derecho español, Barcelona, 1970, pp. 130, 195 y ss. y 207 y ss; del mismo autor, "Derecho histórico español”, Barcelona, 1974, pp. 75-85; Francisco Tomás y Valiente, Manual de Historia del 
dentro del orden jurídico de la época, pero raramente se ha expresado preocupación por el tema concreto que me propongo examinar en estas páginas. ${ }^{4}$ Las respuestas a nuestros interrogantes iniciales suelen darse desde el ángulo legal, de tal modo que cuando se advierte la vigencia de la doctrina a pesar de la ley, se llega a afirmar que esa vigencia era de "hecho", o se la califica de "abuso" o "irregularidad". Su papel es destacado principalmente con relación a la elaboración y el comentario pero no como directa formadora del derecho. Esto se explica a la luz de la clasificación dogmática de las fuentes impuesta en el siglo XIX, en donde la ciencia jurídica quedó subordinada a la ley, sin posibilidad de alcanzar un rango superior.

Es tiempo de que la historiografía jurídica salga, en este punto como en otros, de este encierro. Para ello se impone apuntar hacia el examen integral del tema, ubicándolo dentro de la compleja problemática que lo explica y condiciona. Ello nos lleva a cambiar el ángulo de observación, rompiendo la estrechez conceptual e histórica de la mencionada clasificación dogmática. Mirar el asunto sólo bajo la lectura de los textos legales es quedarse en una visión parcial, incapaz en sí misma de descifrar la realidad. Es preciso acudir entonces a un enfoque histórico que nos permita partir de la situación en que se encontraba la doctrina de los autores a comienzos de la Edad Moderna y recorrer el proceso de subsistencia y crítica que condujo, a través de una lenta declinación, hasta su final sometimiento a la ley en la época de la codificación. $^{5}$

derecho español, $2^{a}$ edición, Madrid, 1980, pp. 246-247; Abelardo Levaggi, Manual de historia del derecho argentino, t. I, Buenos Aires, 1986, pp. 258-259.

4 Entre los estudiosos que han advertido la importancia de esta fuente en el derecho canónico indiano, se encuentra Roberto I. Peña, "Fuentes del derecho indiano: los autores. Anacleto Reiffenstuel y el Jus Canonicum Universum”, en Anales de la Academia Nacional de Derecho y Ciencias Sociales, t. XXVI, Córdoba, 1988, pp. 111 ss. También Francisco Tomás y Valiente, en El derecho penal de la Monarquía absoluta, Madrid, 1969, hace interesantes aportes de orden general en el extenso capítulo dedicado a la jurisprudencia penal e intenta responder a la pregunta "¿qué valor o fuerza para obligar tenía la doctrina de los autores?” (pp. 134-135). A su vez, José LuIS DE Los Mozos destaca en sus estudios sobre el Derecho civil hispano, la fuerza que en esa época tuvo una concepción jurisprudencial del derecho (véase su volumen Derecho Civil. Método, sistemas y categorías jurídicas, Madrid. 1988, especialmente, pp. 58 y 101). Por su parte, Mariano Peset Reig encuentra en la doctrina "una auténtica fuente del derecho" ("Derecho romano y Derecho real en las Universidades del siglo XVIII", en AHDE, XLV, 1975, p. 288).

5 Para una consideración de esta cuestión y de otras desenvueltas en este trabajo, son altamente sugerentes los estudios de Luigi Lombard, Saggio sul diritto giurisprudenziale, Mi- 
Es también necesario valerse de un enfoque social, que permita observar la actuación de los juristas como grupo influyente en la sociedad, en el poder político y en la administración de justicia, suscitando adhesiones y resistencias. Asimismo la conexión con otros ámbitos de la cultura resulta de provecho para apreciar la fuerza ejercida por las opiniones o, en contraste, el avance del criterio de razón, y para determinar el alcance de la autoridad obtenida por el libro impreso en los comienzos del arte de Gutenberg. Es también propio del itinerario histórico que nos interesa, observar la formación de la Monarquía hispana, como aparato estatal, donde la ley - ¿enemiga aparente de nuestra fuente jurídica? - fue utilizada como medio de acción conducente a la centralización y a la uniformidad. No debe faltar, en fin, un enfoque más estrictamente jurídico para detectar las tensiones y entrecruzamientos entre los distintos modos de creación del derecho y para explicar el prestigio y la difusión alcanzados por autores y libros jurídicos.

En la conjunción de estos factores debemos encontrar principalmente la fuerza impulsora de la controvertida doctrina de los autores en el mundo hispánico. No pretendo haber reflejado satisfactoriamente en estas páginas todos estos enfoques ni mucho menos haber dado respuesta a los interrogantes que, en tan amplio marco, pueden suscitarse. En todo caso, apuntan a establecer lo que, a mi juicio, es indispensable para la acabada comprensión de nuestro tema. De tal modo se podrá mejorar esta visión incompleta, detectando más fácilmente sus omisiones e insuficiencias.

Cierro estos párrafos introductorios con unas indicaciones aclaratorias. La denominación de "doctrina de los autores" ha sido preferida en este trabajo por entenderla de un lado más abarcadora y de otro más familiar al lector de hoy. Sin embargo, con alcance equivalente son utilizadas en estas páginas las expresiones "opiniones de los autores" y "opiniones de los doctores", muy usadas en la época. En todo caso aquella denominación debe entenderse como perteneciente a la práctica y no a la teoría, conforme a la naturaleza que le era reconocida al llamado "derecho de juristas".

Sólo para dar orden y claridad a la exposición he considerado conveniente establecer en los principales capítulos una separación cronológica, colocando de un lado los siglos XVI y XVII, de otro el XVIII. No dudo de que hay buenas razones sustanciales para afirmar esa separación pero es también

lano, 1975, pp. 371 y ss. y Alejandro Guzmán Brito, La fijación del derecho, Valparaíso, 1977, pp. 35 yss. 
aconsejable en nuestra materia prevenirse contra los cortes temporales abruptos.

En el tema que abordamos - como en otros también - lo indiano no se explica enteramente sin su raíz castellana. A su vez, esa creación ha influido sobre el ordenamiento interno de Castilla. ${ }^{6}$ De ahí que frecuentemente el enfoque sea comprensivo de ambos y los ejemplos tengan esa doble procedencia, aunque el objeto específico sea propiamente indiano. Bien vale recordar al respecto que - como afirma García-Gallo - "el derecho indiano nace fiel a la práctica y doctrina jurídica de la Europa del Cuatrocientos” y que la literatura jurídica indiana de los siglos XVI a XVIII es "una proyección sobre el Nuevo Mundo de la entonces existente en Europa"7 Un tratamiento enteramente separado hubiese sido una tarea peligrosamente artificial y sobre todo desprovista del encuadre espacial que le corresponde.

\section{Juristas, sociedad y poder político}

1. Opiniones y obras jurisprudenciales, ¿creadoras de Derecho?

Cuando se plantea el tema de la doctrina de los autores entre los modos de creación del derecho, una natural inclinación - incentivada por la Dogmática Jurídica - nos impulsa a averiguar cuál era su ubicación jerárquica, si se trataba de una fuente autónoma y si, en fin, su papel era principal o subordinado. Como ya lo señalé en otra oportunidad, para mí es inadecuado buscar una rigurosa separación y jerarquización entre las distintas fuentes en un Derecho de textura casuista, como lo era el castellano-indiano. Unas y otras concurrían, de modo inescindible, en la realización del derecho, a través de la solución de los casos concretos. La separación es difícil de establecer en la práctica. La ley solía pasar bajo la noticia o interpretación de los autores; la costumbre bajo la conducción del legislador o del autor, quienes a veces la creaban y transmitían; y la doctrina aparecía con frecuencia vinculada a las dos anteriores. La opinión del jurista era emitida, casi siempre, en base a un sólido entramado de elementos provenientes de diversas fuentes y no como un juicio abstracto y original. Su génesis pues resulta compleja.

6 Lalinde Abadía, “La creación...”, cit., p. 318.

7 García-Gallo, “La ciencia jurídica...”, cit., pp. 55, 163 y 197-198. Conforme, Sánchez Bella, "Los comentarios...", cit., p. 401. 
Una atenta observación de la realidad muestra entonces la presencia convergente de las distintas fuentes. El jurista casuista necesitaba tener a su alcance la mayor cantidad de elementos jurídicos para decidir los casos y era renuente a desprenderse de algunos de ellos o a establecer abstractas definiciones, clasificaciones y jerarquías que pudiesen de antemano, comprometer la libre utilización de dichos elementos en la ocasión oportuna. De ahí que evitara la expresa exclusión de algunos de ellos, con carácter general. Es más, las distintas fuentes no actuaban "en bloque", pretendiendo cubrir por si todo el horizonte jurídico, sino que la mayor fuerza de unas y otras se registra por áreas, por materias y aun se mostraba variable ante las diversas situaciones. En estas condiciones, el apoyo de la obra jurisprudencial debió ser fundamental. Esto sin olvidar el permanente juego de tensiones y hasta conflictos entre las distintas fuentes, debido tanto a pequeñas disputas de poder y jurisdicción como a factores de mayores proyecciones en el tiempo.

Se impone determinar en qué consistía ese acto creador de derecho atribuido a la doctrina con fuerza directa, ya sea en primer grado o en otro sucesivo. En el Derecho castellano-indiano se pueden apreciar dos modos principales a saber:

a) las opiniones de los autores que en sí mismas alcanzaban fuerza vinculante. Esas opiniones emergían de forma variada pero solían ser el resultado de un conjunto de razones y argumentos, leyes y costumbres, decisiones y otras opiniones, ejemplos y reglas. No eran el mero pensamiento, libre y original, del autor.

b) la obra jurisprudencial en su conjunto, cuando alcanzaba prestigio social y jurídico sobresalientes. Era propiamente un libro que gozaba de auctoritas. Se recurría a ella para resolver situaciones planteadas de la misma manera que se lo hacía con los cuerpos legales. Aparecía como depositaria del saber y fijadora de jurisprudencia.

Ambos modos no eran - en rigor dogmático - fuentes formales, autónomas, cuya invocación se hiciese en abstracto, desligada de la realidad fáctica y jurídica. El influjo de la opinión era mayor en aquellas materias donde la ausencia de normas legales y consuetudinarias precisas, daba lugar a la controversia. El campo de acción de la obra jurisprudencial fue más dilatado. ¿Podría acaso afirmarse que desempeñó una función directiva de las distintas fuentes?

Ahora bien, en cada uno de los modos enunciados encontramos tres niveles a atender, conjunta o separadamente, según la época, el ámbito 
geográfico y la temática, a saber: a) los autores del Derecho común, civil y canónico; b) los autores del Derecho castellano; y c) los autores del Derecho indiano. Estos niveles actuaban en la práctica conjuntamente. El primero aparecía en materias fundamentales como hegemónico, a tal punto que incorrectamente se ha identificado la doctrina de los autores con ese solo nivel. A medida que avanzaron los tiempos modernos, se produjo un lento desplazamiento del centro de gravedad de dichos autores a los hispanos. En efecto, durante el período que estudiamos, es dable advertir un nítido crecimiento de la producción y prestigio de los autores castellanos e indianos quienes, al tiempo que asimilaban las doctrinas romanistas, introducían vistas más modernas en el tratamiento de los asuntos jurídicos. El momento culminante de esa fase ascendente se produjo en el siglo XVIII cuando se intentó desplazar, con escaso éxito por cierto, a los autores del Derecho común.

Las opiniones de los autores se podían hallar dentro de distintas clases de obras. De igual modo los libros jurisprudenciales podían pertenecer a esos mismos géneros: glosas y comentarios a textos legales, tratados generales o de cuestiones particulares, compendios, repertorios, diccionarios, etc. Lo cierto es que en la literatura jurídica castellana e indiana de los tiempos modernos hubo una extraordinaria abundancia de obras de estos géneros que Sánchez Bella atribuye al auge alcanzado por la profesión jurídica, a la difusión de la imprenta, a la diversidad de cuerpos legales vigente y a la búsqueda de concordancias con el Derecho común. ${ }^{8}$ Considero pertinente agregar entre las causas de ese auge al papel directivo que entonces ostentaban los autores.

La conjunción castellano-indiana fue armónica y duradera. Sin embargo, la distinción que tempranamente se hizo en el Derecho indiano entre asuntos de gobierno y de justicia es probable que haya actuado como factor de separación parcial entre ambos niveles.

En el movimiento de la vida jurídica, los modos y niveles enunciados tendían a esfumarse, haciendo muy difícil, cuando no imposible, el intento de distinguirlos en su funcionamiento. La manera de operar de esta fuente del Derecho pertenece a una técnica difícil de comprender para nosotros, pues se ha perdido la tradición, transmitida generacionalmente de jurista a

8 Véase Sánchez Bella, “Los comentarios...”, cit., pp. 387-388. El contenido de este estudio es mucho más amplio que el título, algo restrictivo. Rico en noticias y sugerencias, mantiene su interés actual, pese al tiempo transcurrido desde su aparición. 
jurista, de la misma manera que se pierden los secretos artesanales. Su reconstrucción puede hacerse pacientemente, sobre las huellas dejadas, con una laboriosa interpretación. Las opiniones se asemejaban a un denso y extendido tejido, sobre el cual se continuaba hilando, siguiendo la trama. Sus soluciones nuevas no eran revolucionarias ni provenían del libre vuelo del pensamiento. Lo nuevo se apoyaba en el Derecho existente. En ello precisamente radicaba su fuerza jurídica. Si fuese necesario, para apurar la comprensión, encontrar un símil en nuestros días, tal vez la jurisprudencia de los tribunales nos pudiese servir a esos fines.

\section{Opiniones y opiniones comunes. La auctoritas, como sustento}

La opinión era el embrión de esta fuente jurídica. No se daba sólo en la esfera del Derecho. Como decía un escritor a fines del siglo XVI "la opinión se ha hecho señora del mundo"'? Bajo el influjo aristotélico, en los dominios del saber donde no era posible alcanzar una certidumbre absoluta, las opiniones constituían un elemento apreciado y cultivado. Filósofos, teólogos, moralistas, políticos y juristas se servían frecuentemente de las mismas para apoyar sus argumentos.

Para comprender la vigencia de las opiniones dentro de una sociedad, debemos separarnos de la estrecha visión legalista del Derecho - hoy predominante - bajo la cual no se concibe la existencia de normas vinculantes ajenas a la sanción del poder público. Dicha vigencia reposaba en la autoridad que se atribuía a determinados autores y obras, y actuaba separada o junto al poder pero sin confundirse con éste. Ese sentido de la voz autoridad aún es usado en nuestra lengua, tal como lo recoge el Diccionario académico en una de sus acepciones, que dice: "Crédito y fe que, por su mérito y fama, se da a una persona o cosa en determinada materia". Ha sido, sin embargo, mejor desenvuelta por García Pelayo, al acudir al vocablo latino originario auctoritas para hacer de este modo más pronunciada su separación de otras acepciones - y de vocablos derivados - con significados distintos y hasta opuestos. Las finas observaciones de García Pelayo - que aquí recojo libremente - llevan a establecer que la auctoritas se basaba de una parte en la posesión de cualidades estimables concentradas en personas o corporaciones,

9 Antonio Pérez, Norte de príncipes, virreyes, presidentes... (1597), Madrid, 1788, p. 14. 
y de otra en el reconocimiento y confianza que les otorgaba la sociedad. ${ }^{\mathbf{1 0}}$ En el área del Derecho, dicha autoridad consistía en el reconocimiento social de ese saber en el círculo de juristas, con la consiguiente aceptación de sus dictámenes, expresados en opiniones y libros, sin que propiamente tuviesen necesidad de una sanción del poder público ni fuesen respaldados por otro medio coactivo.

Esta noción de auctoritas puede explicarnos la subsistencia en esa época de nuestra fuente del derecho. Durante mucho tiempo mantuvo su rasgo esencial, aunque en la realidad no se daba de forma pura ni tampoco permaneció inmutable. Así apareció frecuentemente combinada con la noción de poder público, siendo finalmente absorbida en gran parte por ésta. Se trata de uno de esos procesos de transformación léxica, que encubre una evolución conceptual más profunda.

Para ostentar autoridad e invocarse, la opinión debía alcanzar el grado de probable. Podía ser sólo probable, más probable y probabilísima. Necesitaba, para acentuar su fuerza, un número variable de autores que la siguieran. Por esta vía se podía llegar a la denominada "communis opinio doctorum", cúspide del sistema. Sin embargo, las opiniones navegaban precisamente en los mares más problemáticos del derecho, donde frecuentemente surgía la controversia. De tal modo, esa "opinión común" raramente carecía de contradictores. Asechadas por otros dictámenes, a veces unas opiniones comunes aparecían contrapuestas con otras también comunes.

La mención de opiniones y autores aparecía pues no sólo como ostentación de conocimiento y erudición - como a veces se ha limitado a señalar sino que era un elemento necesario en el tratamiento de toda cuestión controvertida o en el desarrollo de una argumentación. Según veremos, el abogado, el moralista o el juez - cada uno en su actividad específica - debían apoyarse en dichas opiniones. Las distintas clases ofrecían la posibilidad de elegir aquellas que mejor se acomodaran al caso planteado, sobre todo en aquellos aspectos donde la controversia asomaba con frecuencia, dada la incerteza o discordancia normativas, la ausencia de toda regulación, o la misma peculiaridad de la situación a resolver.

10 Sobre esto Manuel García-Pelayo, "Auctoritas", en Revista de la Facultad de Derecho, núm. 42, Caracas, 1969, pp. 9 y ss. Sobre este tema, dicho profesor dirigió un seminario en esa Facultad, publicándose varios de los trabajos resultantes en el mismo número de la Revista. 
Coing ha señalado la importante función que tuvo la "communis opinio doctorum" en el desenvolvimiento del derecho letrado de la Edad Media, dentro de un saber donde no era posible arribar a una certidumbre absoluta y por lo tanto las soluciones estaban dentro del círculo de lo probable. ${ }^{\mathbf{1 1}}$ Esta misma creencia impregnaba la jurisprudencia de los comienzos de los tiempos modernos, la que mantuvo una preferente atención por la solución adecuada de los casos, participando de esta característica nuestro ordenamiento castellano-indiano.

La opinión pues se sustentaba en el argumento de autoridad. ${ }^{\mathbf{1 2}}$ El uso de este argumento en el Derecho tiene sentido si se considera que el conocimiento jurídico es problemático, prudencial, pues si, en cambio, se sostiene que es una ciencia del tipo de la geometría o de las ciencias naturales, su utilización carece de valor. En la medida en que durante la Edad Moderna se produjo un lento cambio de criterio en el sentido indicado, el argumento de autoridad fue paulatinamente relegado hacia su destierro en el siglo XIX.

Ya desde el siglo XV se percibían síntomas de una crisis de subsistencia, que condujo a la lenta declinación del sistema de las opiniones, hasta su desaparición como fuente directa. Transcurrieron así más de tres centurias, precisamente el período que abordamos en estas páginas, durante las cuales la vigencia de las opiniones y libros con auctoritas - elementos claves de la jurisprudencia casuista - coexistió con una fuerte - y al fin demoledora corriente crítica.

En ese proceso de declinación actuaron factores internos, de la misma fuente, y otros externos. Tomás y Valiente ha enfatizado los primeros al señalar que contribuyeron a su decadencia y esterilidad los intentos de fijar exageradamente la teoría de la "communis opinio", de reunir colecciones de ellas y de exagerar su autoridad, con lo que se produjo "una mitificación

11 Helmut Coing, "Trois formes historiques d'interprétation du droit. Glossateurs, pandectiste, école de l'exégèse", en Revue historique de droit français et étranger, t. XLVIII, París, 1970, p. 536. Véase al respecto V. Piano Mortari, "L'argumentum ab auctoritate nel pensiero dei giuristi medievali", incluido en su obra Dogmática e interpretazione. I giuristi medievali, Napoli, 1976, pp. 75-91.

12 Me apoyo en Rogelio Pérez Perdomo, "El argumento de autoridad en el razonamiento jurídico", en Revista de la Facultad de Derecho, núm. 42, Caracas, 1969, pp. 118 y ss. Si bien el autor aborda el estudio desde la interesante perspectiva que ofrece para la renovación de la actual ciencia del derecho, considera que "el tema es seguramente fundamental para el estudio del pensamiento jurídico y clave para la comprensión de su historia” (p. 140). 
conservadora de la tradición”, denotándose una incapacidad para alcanzar resultados nuevos. ${ }^{13}$

Estos factores a su vez se originaron en el crecimiento desmesurado de autores y opiniones en el ámbito del Derecho común, en la pluralidad de ordenamientos de los reinos europeos, acompañados de sus comentadores, $\mathrm{y}$ en el consiguiente aumento de la incertidumbre a que daban lugar las controversias. Esto llevaba - según se decía por entonces - al incremento y prolongación de los procesos judiciales. Para cortar esa proliferación de pareceres se empezó a reclamar, entre otros recursos, la intervención del rey - legislador para que encauzase la alegación de los doctores y para que también, en ocasiones, adoptase soluciones legislativas a ciertas controversias de opiniones. ${ }^{14}$

La opinión y el argumento de autoridad encontraron sus primeros críticos en la época del Humanismo. El ataque se acentuó con el Racionalismo y ya bajo la Ilustración ambos habían perdido el prestigio antes ostentado, pero sin desaparecer. Esta postura crítica envolvió naturalmente a la esfera jurídica, cuando no se originó en ella misma. La antigua estimación hacia las opiniones se tornó entonces a favor de la crítica racional. El argumento de razón empezó a enseñorearse sobre el de autoridad. La sátira se encargó también de desnudar una erudición falsa, abarrotada de citas postizas y menciones de autores no leídos. Se condenaba así el abusivo uso del recordado argumento de autoridad.

La crítica pretendía dejar al descubierto los endebles fundamentos en que se apoyaban las opiniones, ya sea en su autoridad, ya sea en su estructura racional. Todo el mundo de las opiniones aparecía oscurecido por la incertidumbre, la duda. Para los escritores racionalistas, las opiniones constituían un "laberinto" del cual sólo podía salirse ayudado por "la razón natural y buen sentido", según decía uno de ellos. ${ }^{15}$ Eran ya los tiempos en que se aceleraba la declinación de esta fuente de derecho, según lo veremos páginas más adelante.

13 Tomás y Valiente, Manual..., cit., pp. 301-302.

14 Alejandro Guzmán Brito, "Decisión de controversias jurisprudenciales y codificación del derecho en la época moderna”, en $A H D E$, t. L, 1980, pp. 854 y ss.

15 Juan Francisco de Castro, Discursos críticos sobre las leyes y sus intérpretes..., Madrid, 1765 (edición, 1829, I, p. 259). 
3. El saber de los juristas: peso social e influjo político

Para que la doctrina de los autores gozara de prestigio social y tuviese fuerza jurídica era preciso que la respaldase una organización, con poder sobre la comunidad. En la Baja Edad Media española - y en forma paralela en otros reinos europeos - se fue constituyendo paulatinamente un grupo de "hombres de saber" que, en la primera mitad del siglo XVI apareció consolidado como un estamento. Según Maravall, desde el siglo XII los expertos juristas empezaron a ser estimados en razón de su ciencia, aprendida formalmente en los claustros universitarios, constituyendo un nuevo grupo social, con características peculiares, que adquirió peso en el despacho de los negocios públicos y en la justicia hasta llegar a monopolizar determinadas funciones. Apoyaron a la realeza, contribuyendo a su fortalecimiento y participaron activamente en la construcción del aparato de poder. El grupo se convirtió, según dicho autor, en un estamento con honor, prestigio y posibilidades económicas. Se le daba un trato social peculiar y hasta se le asignaba un tipo somático. Distinguíase por su afán de disputar y razonar. ${ }^{\mathbf{1 6}}$

Este estamento tuvo un papel relevante, junto a otros, en el Nuevo Mundo. Bajo el atractivo título de "una colonización de gente de leyes", Malagón ha puesto de relieve la temprana presencia directiva de los letrados en los negocios públicos y en la justicia. ${ }^{17}$ Estas posibilidades abiertas al jurista en la época explican la inclinación predominante que se aprecia por entonces en las Universidades hispanas hacia los estudios jurídicos. ${ }^{18}$

El cultivo del derecho se convirtió en un monopolio de este estamento. Era un saber propio, legado por los doctores medievales y consolidado en torno a los Derechos civil y canónico. Empero desplegaba miras más flexibles en las nuevas materias de gobierno que la organización de la Monarquía hispana exigía.

16 José A. Maravall, “Los 'hombres de saber' o letrados y la formación de su conciencia estamental” (1953), en Estudios de historia del pensamiento español, serie 1 ${ }^{\text {a }}$, Madrid, 1973, especialmente pp. 369-384.

17 Javier Malagón Barceló, Estudios de Historia y Derecho, Xalapa, México, 1966, pp. 81-100.

18 Sánchez Bella, “Los comentarios...”, cit., p. 389; Richard L. Kagan, Universidad y sociedad en la España moderna, Madrid, 1981, pp. 119 yss. 
La absorción de las atribuciones para crear las normas legales por parte del príncipe y del aparato estatal en formación significó una expropiación de la auctoritas, ${ }^{19}$ pero ello no impidió que el ejercicio de esa actividad creadora continuase en el círculo de juristas. Estos, al colaborar con el rey en la construcción de la Monarquía, utilizaron como medio de acción ordinaria a las leyes, ya sueltas, ya orgánicamente dispuestas. Esto último tuvo, como es sabido, gran despliegue en el Derecho indiano. Koschaker no encuentra, aun dentro de un "derecho de juristas", hostilidad entre uno y otro medio de expresión, pues finamente apunta que el jurista necesitaba de las leyes para hacer ciertas reformas radicales que no podían hacerse con el lento hilado del tejido de las opiniones. ${ }^{20}$ Si por una parte las leyes actuaban sobre las opiniones, encauzándolas y hasta resolviendo sus controversias, por otra parte pasaban bajo el severo tamiz de las opiniones, adecuando su sentido a los principios de la ciencia jurídica.

No voy a reiterar lo que ya se ha dicho sobre la importancia que tuvo la ley en la configuración del ordenamiento castellano-indiano de los tiempos modernos. Me refiero tanto a las disposiciones emanadas desde el Consejo de Indias como a las dictadas por los distintos niveles de autoridades y órganos asentados en América y Asia. Esto ha llevado a caracterizar al indiano como "derecho legal" ${ }^{21} \mathrm{El}$ avance de éste principalmente se aprecia en las materias nuevas surgidas con la colonización del Nuevo Mundo: la ordenación política y eclesiástica, la conquista y población, el asentamiento urbano, la relación con los indígenas, la organización hacendística, el comercio y transporte marítimo, etc. Desde leyes principistas a disposiciones casuistas hubo muchos millares que - ante tal proliferación - obligaron a diferentes esfuerzos de fijación legislativa. Pero ese "derecho legal" era tolerante y receptivo de la norma consuetudinaria, según he tenido ocasión de demostrarlo en otras ocasiones. ${ }^{22}$ Ahora cabe también señalar una postura de respeto hacia

19 García Pelayo, cit., pp. 46 y ss.

20 P. Koschaker, Europa y el derecho romano, Madrid, 1955, pp. 266-267.

21 Lalinde Abadía, "La creación...," cit.; Víctor Tau Anzoátegui, "La noción de ley en América hispana durante los siglos XVI a XVIII", en Anuario de Filosofía Jurídica y Social, núm. 6, Buenos Aires, 1986, pp. 193-232. Reproducido en ídem, La Ley en América Hispana. Del descubrimiento a la emancipación. Academia Nacional de la Historia, Buenos Aires, 1992, pp. 25-65.

22 Víctor Tau Anzoátegui, "La costumbre jurídica en la América española (siglos XVIXVIII)”, en RHD, núm. 14, Buenos Aires, 1986, pp. 355-425. Reproducido en ídem, El 
la consolidada "communis opinio doctorum" e incluso de aceptación hacia la nueva doctrina desarrollada en Castilla e Indias.

El despliegue de un "derecho legal" era la única respuesta posible dentro del círculo de juristas, frente al poderoso estímulo exterior recibido. Sólo las leyes podían intentar resolver con rapidez las numerosas situaciones nuevas planteadas. El lento mecanismo formativo de la opinión no estaba en condiciones de operar en esas circunstancias. Sin embargo, ello no significaba de modo alguno abandonar el cultivo de una tradición científica, que reposaba en la fuerza creadora de la jurisprudencia de los autores. Es de suponer que esa tradición tenía más peso en aquellas ramas o materias jurídicas menos afectadas por los cambios, pero también las viejas opiniones servían de apoyo a las nuevas argumentaciones de los juristas indianos.

Ya señalamos que la doctrina de los autores encontraba dificultades internas para asimilar la multitud de opiniones y resolver satisfactoriamente sus controversias dentro del Derecho común. Era imposible que, en esas condiciones asumiera un papel directivo en el trasplante del Derecho castellano al Nuevo Mundo. La ley, operada por los mismos juristas, vino en su ayuda, resolviendo situaciones y también algunas de sus controversias. Se fueron, cada vez con más frecuencia en los siglos XVII y XVIII, reclamando declaraciones del rey en cuestiones dudosas que sirviesen además de regla para futuros casos. Mientras fueron los propios juristas quienes eligieron entre las opiniones en disputa podemos decir que esta fuente del derecho mantuvo su vigorosa presencia. Al fin y cabo, eran esos juristas quienes elaboraban la ley decisoria y sólo la potestad real acudía en su apoyo.

La situación sutilmente se fue alterando. Al acentuarse el absolutismo político en el siglo XVIII la expropiación de la auctoritas - mencionada en páginas precedentes - se hizo extensiva al propio ejercicio de la actividad jurídica creadora. El sostenido crecimiento de la ley como fuente del derecho llevó a estrechar el campo de la acción de la doctrina de los autores. De una parte la fuerte presencia de las teorías absolutistas, de otra las tendencias racionalistas y sistemáticas, se unieron en la pretensión de establecer un sistema legal uniforme con aptitud de abarcar todos los casos posibles. La regulación de los casos dudosos empezó a hacerse con prescindencia de

poder de la costumbre. Estudios sobre el derecho consuetudinario en America Hispana hasta la emancipación. Instituto de Investigaciones de Historia del Derecho, Buenos Aires, 2001, pp. 83-156. 
aquella doctrina de los autores. Hasta el comentario ceñido al texto legal fue mal visto por algunos. Y así ni la Recopilación de 1680 gozó de una glosa o comentario completo, publicado. Es más, según observa Sánchez Bella, se registró un pronunciado declive en la literatura jurídica del siglo. ${ }^{23}$ Sólo se mantuvo la autoridad de algunas obras jurisprudenciales que habían logrado en el pasado sus laureles. La declinación de nuestra fuente del derecho entraba en su fase final.

La transferencia de la facultad de crear el derecho de un círculo de juristas al aparato estatal se operó lentamente a través de estos siglos de tal modo que fue casi imperceptible para las distintas generaciones que vivieron durante ese proceso. Desde el ángulo social fueron los mismos letrados - poseedores exclusivos de una ciencia sin la cual no se concebía el orden social - quienes continuaron ejerciendo la creación jurídica, ya en el cultivo de las opiniones, ya en la elaboración de las leyes. Pero el cambio producido fue significativo. La doctrina de los autores era un saber más cerrado privativo del círculo de los juristas, al cual no tenía acceso el profano. Su persistencia se debe, entre otros factores, a la preferencia que los juristas posiblemente sentían por ese saber que les era enteramente propio. En cambio, el sistema legal que se preconizaba fervientemente en el siglo XVIII era presentado como accesible a todos, desnudo de cualquier posibilidad de interpretación o glosa.

El prestigio social y las posibilidades económicas de los juristas se mantuvieron, acrecentados tal vez por el creciente poder político que les daba su activa participación en el aparato burocrático de la Monarquía. Esta misma situación influyó decisivamente para que hubiese una prolongada convivencia entre estas dos fuentes del derecho durante toda la Edad Moderna, más allá de la espuma levantada por las corrientes críticas. También influyó para que la etapa final - con el triunfo hegemónico de la legislación y la marginación de la doctrina, a la que se le asignó un nuevo papel - estuviese desprovista de huellas conflictivas.

Queda flotando una pregunta final: ¿hasta cuándo conservaron los juristas una genuina conciencia estamental o corporativa que respaldara la fuerza vinculante de sus opiniones y obras jurisprudenciales? María del Refugio González, al plantear la cuestión para México, responde que presuntivamente ello ocurrió en las últimas décadas del siglo XIX, pues hasta 1871 encuen- 
tra rasgos que permiten aún detectar la presencia de un sentimiento corporativo entre los letrados. ${ }^{24}$ Sin la pretensión de dar una respuesta concreta, en términos generales puede sostenerse que esa conciencia estamental se fue diluyendo a lo largo del siglo XIX.

\section{En torno a las "leyes de citas"}

Para completar la cuestión tratada me parece necesario que nos ocupemos de los esfuerzos para encauzar, a través de normas legales, la invocación de los autores del Derecho común en la Castilla del siglo XV. Son las conocidas "leyes de citas", a las cuales ya se había recurrido en el propio Derecho romano. Algunos estudiosos han puesto atención decisiva en estas leyes para determinar la vigencia o no de la doctrina de los autores como fuente directa del derecho. Para mí, el interés se halla en que muestran los problemas que ocasionaban la multitud de opiniones y la creencia en un remedio legal, pero también evidencian la fuerza que ostentaba la doctrina al punto que llegó a fracasar la tentativa de encaminarla. Se trata además de uno de los más interesantes ejemplos de la vigencia de la auctoritas, que trataba de ser encauzada - ¿y también reforzada? - por el poder público. Veamos.

Aduciendo los motivos ya indicados, para evitar que los pleitos se prolongasen indefinidamente "por causa de las muchas y diversas y aun contrarias opiniones de Doctores que los letrados y abogados alegan y muestran" en pleitos civiles y causas criminales, se dispuso por pragmática dada por Juan II el 8 de febrero de 1427 que no se pudiese invocar y juzgar siguiendo la doctrina de legistas y canonistas posteriores a Juan Andrés y Bartolo, ni tampoco hacerlo por los que formasen opiniones en adelante. ${ }^{25} \mathrm{~A}$ fines de la misma centuria una nueva disposición, contenida en la Ordenanza de Madrid de 1499, volvía a ocuparse de la cuestión. Decía textualmente que dado que "muchas veces acaece que en la decisión de las causas ha habido y hay mucha confusión por la diversidad de las opiniones que escribieron mandamos que en materia canónica se prefiera la opinión de Juan Andrés y en defecto de la opinión de Juan Andrés se siga la opinión del Abad de

24 María del Refugio González, El derecho civil en México. 1821-1871. Apuntes para su estudio, México, 1988, pp. 150-153.

25 Miguel Ángel Pérez de la Canal, “La pragmática de Juan II, de 8 de febrero de 1427”, en AHDE, XXVI, 1956, pp. 659-668. 
Sicilia; y en materia legal se prefiera la opinión del Bartolo y en defecto de ella se siga la opinión del Baldo". ${ }^{26}$ Este mandato real tuvo poca duración. En las Leyes de Toro de 1505, alegándose que dicho precepto había provocado "mayor daño e inconveniente" del que se buscaba remediar, se le revocó, prescribiéndose que en el orden y determinación de los pleitos y causas se guardase solamente la prelación legal de Alcalá de 1348.

Las disposiciones citadas constituyen testimonios de interés para corroborar la importancia que tenían las opiniones de los autores. Revelan también un estado de crisis de esa doctrina, pues aparentaba carecer de los mecanismos propios para dirigir y depurar ese crecimiento desmedido de opiniones. La ley aparecía entonces como instrumento necesario para dar ese orden reclamado. Su intervención se limitaba en una ocasión - en 1427 - a colocar una barrera en el tiempo para detener la avalancha de opiniones; y en otra en 1499 - a dar preferencia al dictamen de unos doctores sobresalientes. En cambio, la ley de Toro podía llevar a una interpretación más favorable a la preeminencia de la ley, con marginación de la doctrina. Pero esta eventual intención del legislador no fue seguida por los juristas. Como lo ha señalado Carlos Petit, los juristas castellanos, a partir de entonces, consideraron derogadas las "leyes de citas" y dieron entrada por vía supletoria a la doctrina del Derecho común, unos enfatizando el canónico, otros el civil. ${ }^{27}$ De tal modo, fueron los mismos juristas quienes abrieron nuevas posibilidades de acción a la doctrina, sin que en adelante se dictaran leyes que entorpecieran su despliegue.

El examen de los textos legislativos de Alcalá y Toro - aplicables en Indias - nos lleva a verificar una decidida preferencia por la norma legal, pero nada autoriza a suponer que hubiese una manifiesta intención de prescindir de otros modos de creación jurídica tan arraigados como la costumbre o la opinión de los doctores ¿Acaso era posible expulsar a éstos de un orden

26 Transcribo textualmente - con modernización de la ortografía - esta disposición en razón de que la mayoría de los historiadores del derecho sólo la han podido conocer a través de la mención que de la misma se hace en las leyes de Toro. Aquilino Iglesia Ferreiros se ha ocupado de la cuestión en una breve nota titulada "Saberes traslaticios", en $A H D E$, t. LI, 1981, pp. 685-688.

27 Carlos Petit, “Derecho común y Derecho castellano. Notas de literatura jurídica para su estudio (siglos XV-XVII)", en Tijdschrift voor Rechtsgeschiedenis, t. L, Leiden, 1982, pp. 157 y ss. Véase también Peset, “Derecho romano...”, cit., pp. 279-281 y 284-285. 
jurídico en el cual estaban integrados y cumplían una función irremplazable? Los testimonios que utilizaré en los siguientes apartados irán dando respuesta a éste y otros interrogantes vinculados al carácter de dichos ordenamientos legislativos.

\section{Vigencia de los autores en los siglos XVI y XVII. Surgimientode la crítica}

La vigencia de la doctrina de los autores, así como la función que le cupo desempeñar en el ordenamiento castellano-indiano de los siglos XVI y XVII, tal como lo hemos señalado en páginas anteriores, necesitan ser comprobadas con testimonios certeros. Para ello he elegido tres sectores centrales de la vida jurídica: la enseñanza, la actividad profesional en el foro y la decisión judicial. A ello agregamos otro elemento probatorio, que nos llega por la vía opuesta: el que surge de la crítica. Suponiendo que el juicio crítico se ejerce siempre sobre lo existente, adquiere en esta ocasión un inestimable valor. Apreciaremos en esta necesaria acumulación de muchos y variados testimonios tanto los elementos sustentadores de los autores como aquellos otros que permitan establecer síntomas de una declinación en ciernes.

\section{Los autores en las aulas y en los tribunales}

El arte de instruirse en el Derecho no se concebía sin el auxilio de las leyes y de las doctrinas. Ambas aparecían hermanadas en las aulas salmantinas modelo didáctico en todo el mundo hispano - conforme a la ya conocida descripción que hacía Bermúdez de Pedraza a comienzos del siglo XVII, recogiendo otra difundida en décadas precedentes. ${ }^{28} \mathrm{El}$ recurso a los libros jurídicos era también resaltado en los consejos complementarios que el mismo Bermúdez daba a los aprendices. Los autores de Derecho común predominaban con respecto a los castellanos. Incluso, según Petit, la preferencia por la doctrina romano - canónica era manifiesta sobre las mismas

28 Francisco Bermúdez de Pedraza, Arte legal para estudiar la jurisprudencia, Salamanca, 1612, pp. 159-163. La descripción procedía de un opúsculo de Diego del Espino que había tenido buena difusión en la segunda mitad del XVI. También la recogió Alonso de Villadiego (sobre esto, véase Petrt, “Derecho común y Derecho..., cit., 189). 
leyes del reino. ${ }^{29}$ Esta tendencia es corroborada por una sabrosa referencia que, en la época, hace Castillo de Bobadilla, al quejarse porque los "jueces mozos que vienen de nuevo a los juzgados, como traen las leyes en los labios, quieren ganar honra con los Abogados, y cuando se juntan a ver los pleitos, todo es alegar Doctores, y estudian más para ostentación de su ciencia, que para averiguar el punto de justicia". ${ }^{\mathbf{3 0}}$ Este curioso pasaje nos acerca a un enaltecimiento de dicha doctrina, con ciertos aires de ostentación.

El licenciado Francisco de Barreda, relator del Consejo de Indias, admitía hacia 1630 que el conocimiento de los autores era bueno en cuanto "forman, influyen espíritu claro, despierto, acertado en la interpretación del Derecho; hacen jurisconsultos, y diestros en la noticia y distinción de lo justo, que a cualquier provincia que vayan, aunque nueva en costumbres y leyes, se hallan doctos y prudentes, aunque ignorantes de aquellas leyes y costumbres; porque llevan la ciencia de interpretarlas y hacerlas guardar". Este texto tiene doble filo porque la exaltación del papel que cumplían los autores en la formación del jurista aparecía compensado unas líneas más adelante con la puesta en alto de la ley real frente al comentario. Decía entonces Barrera que la "verdadera jurisprudencia" radicaba en las leyes particulares dadas para las Indias. En ellas se hallarán "desatadas todas las dudas, que la curiosidad ambiciosa de los Maestros redujo a nudos y embarazos". Y agregaba: "No es segura la resolución del Consulto, que no se colige de alguna ley: luego en la ley estaba la resolución. Flaqueza es de los ojos, no mirar el sol en su orbe; sino en las resultas últimas de la luz. Queremos conocer el Derecho por la reverberación del Derecho en comentarios; rodeo es de falsos ingenios" ${ }^{31}$

El enredo de este testimonio no deja de ser provechoso para nuestro propósito, pues hace presente, una vez más, esa estrecha conjunción entre leyes - con el interesante agregado de costumbres - y doctores. Si al final se inclinaba por considerar que la verdadera jurisprudencia estaba en las leyes reales - en este caso las indianas - no quedaban borradas las primeras expresiones que otorgaban a los autores una misión decisiva en la interpretación y guarda del Derecho.

29 Petit, “Derecho común y Derecho...”, cit., p. 190.

30 Politica para corregidores y señores de vasallos (1597), I, VI, 29, (edición utilizada, Madrid, 1775).

31 Antonio de León, Tratado de confirmaciones reales, Madrid, 1630, Introducción. 
Si la formación del letrado no se concebía sin el adiestramiento en autores y leyes, ello iba a repercutir naturalmente en el ejercicio profesional. Así leemos en un libro destinado a los abogados, publicado en 1683, que cuando no encontrase ley, autoridad ni reglas de derecho en que fundarse, había de alegar y traer cuantas autoridades pueda hallar que vengan al caso. A modo de explicación recogía el dicho de otro autor, según el cual "al Juez le bastan fundamentos apoyados en la razón, como superior a la ley, porque es el alma de la misma ley...”32 En la misma época, Gerónimo de Guevara delineaba la imagen de "un perfecto y cristiano abogado" diciendo que entre sus primeras obligaciones estaba determinar que "la causa o pleito pueda defenderse con justificación y seguridad de conciencia”. Para ello - agregaba - era necesario "contar con el apoyo de opiniones probables, aun cuando la parte contraria tenga a su favor opinión mucho más probable". ${ }^{33}$ Mientras el primer texto apuntaba a reflejar una realidad, el reinado de los autores, el segunda estaba directamente orientado a la conciencia del abogado y era precisamente allí donde las opiniones aparecían con fuerza decisiva.

La invocación de autores y opiniones en los escritos judiciales y en otros papeles de gobierno y justicia durante este período no ha sido hasta ahora objeto de estudios minuciosos que permitan obtener un buen conocimiento de su intensidad en las diferentes áreas. Sin embargo, disponemos - hasta que se alcance esa necesaria información - de un sugestivo testimonio, que confirma lo que venimos observando. Se trata del auto acordado del Consejo de Castilla de 1594, el cual buscando abreviar las informaciones en derecho, dispuso que en las mismas se alegase solamente "la Ley o Doctor, que principalmente tocase el punto, y al que refiere a los otros, sin decir los referidos por él...." ${ }^{34}$ Según vemos, se trataba de encauzar el uso que se hacía de la invocación de autores, quitándole tan sólo el abuso de acumular citas. Lo que aquí interesa destacar, una vez más, es que la opinión de los doctores aparecía junto a la ley en un documento cuyo valor era, por encima de todo, reflejar la situación en que se desenvolvía la actividad de los letrados.

32 Melchor de Cabrera Núñez de Guzmán, Idea de un abogado perfecto..., Madrid, 1683, p. 181.

33 Gerónimo de Guevara, Discurso legal de un perfecto y cristiano abogado..., sin lugar ni fecha, fs. 19.

34 Auto acordado II, XVI, 1; 5 de febrero de 1594. Lo recuerda Petit, "Derecho común y Derecho castellano..., cit., p. 186. 
Las sentencias no fundadas de los tribunales superiores de Castilla e Indias constituyen un obstáculo para penetrar en el conocimiento de los elementos que los jueces manejaban en sus decisiones. No obstante, disponemos de algunas huellas que permiten acercarnos a la cuestión planteada.

En primer lugar, es preciso atender a una interesante conjetura que hace Mario Góngora al referirse al desarrollo de la función judicial indiana, válida para la etapa formativa del Derecho indiano, anterior a 1570. Sostiene el maestro chileno que, superada la justicia sumaria de los primeros momentos de la conquista, en cada provincia se fue estableciendo "una justicia legal" que encontró enormes vacíos por la falta de leyes aplicables a los casos, que fuesen conocidas por el tribunal. Esta situación fue salvada, a juicio de Góngora, por una interpretación de las audiencias fundada en "el pensamiento romanista". Ella era "compatible con el respeto a las costumbres y con la sujeción a las leyes escritas; pero la forma y medida concreta de atenerse a unas y otras viene a ser dictada por principios generales de tipo doctrinal". ${ }^{35}$ De acuerdo a esta aseveración, los autores del Derecho común habrían cumplido un rol decisivo en la formación de la justicia en el Nuevo Mundo, referida especialmente a la forma y medida en que se utilizaban las leyes y costumbres. Es decir, que se trataría de una convergencia directa de tres fuentes jurídicas con incidencia en la fijación de la práctica de los tribunales. Me permito recordar esta sugerente hipótesis de trabajo del profesor Góngora, pues advierto lo fructífero que sería profundizar en la misma y aun tenerla en cuenta para un período posterior al fijado.

Dejando por ahora de lado cuestiones aun no definidas, conviene atender a testimonios más concretos. Me parece oportuno recurrir, con respecto a nuestra materia, a algunos pasajes de la Política para corregidores... de Castillo de Bobadilla, en esta ocasión teniendo en cuenta su reconocido papel de guía de gobernantes y jueces en España e Indias durante los siglos XVII y XVIII. Al plantearse la cuestión sobre la residencia de los jueces y la posibilidad de que fuesen condenados por las sentencias dadas en el ejercicio de la magistratura, se explayaba sobre las fuentes que el juez podía utilizar en sus decisiones. Como vemos, se trataba aquí de establecer claramente la responsabilidad del juez, dando consejos tanto a éste como al eventual residenciador. Era pues un

35 Mario Góngora, El Estado en el derecho indiano (Época de fundación 1492-1570), Santiago de Chile, 1951, p. 232. 
enfoque enteramente pragmático. Según Castillo de Bobadilla, no había razón para condenar al juez si en lo que toca al Derecho, hubiese seguido "la decisión de la ley, o la común opinión, o la doctrina de Autores graves o la costumbre recibida", sin que se le pudiese imputar otra culpa o vicio. Y todavía agregaba que si al juez "en cuanto provee y sentencia por ley, o por doctrina, o por razón y epiqueya, le ha de ser tan nocivo su oficio... muy difícil será administrar la justicia”. ${ }^{36}$ La autoridad de quien lo afirmaba, la ocasión en que lo hacía, y la expresa mención que realizaba de la doctrina, exime de comentarios. Pero aun puede seguirse a tan empinado autor en otros pasajes de su libro, en donde podemos encontrarnos con expresiones que corroboran lo ya dicho. Así con respecto a la opinión común de los doctores, afirmaba que debía guiar al juez, no debiendo éste desviarse de sus determinaciones y sentencias "como quiera que tiene fuerza de ley y por tal se debe alegar". ${ }^{37}$ Refirmaba en otra ocasión que si seguía esa opinión o aun otra que no fuese común, no podía acusarse al magistrado de haber juzgado mal. En cambio, era responsable en caso de que fuese injustamente contra común opinión. ${ }^{38}$ Una última mención de Castillo de Bobadilla en la materia que estamos considerando: al referirse a la persona moral del juez, sostenía que los magistrados no eran sabios sólo porque "supiesen las Leyes, y los Autores y doctrinas legales", ${ }^{39}$ lo que constituía una nueva alusión que interesa dejar apuntada.

Estamos en presencia de un testimonio de gran valor, que confirma lo que hemos advertido a través de otros documentos anteriormente presentados. Castillo de Bobadilla enunciaba de modo explícito las fuentes del derecho, a las cuales debía acudir el juez para resolver adecuadamente los casos que se le presentaban. Dominaba en este jurista una concepción amplia de dichas fuentes, en donde además de la ley, doctrina y costumbre, se dejaba ver bajo el recurso a la razón y a la epiqueya - el arbitrio del magistrado. En relación a nuestro tema, podemos constatar que la doctrina aparecía ampliamente destacada - junto a la ley - en los diferentes pasajes citados de la obra. No se concebía la labor del juez sin su conocimiento y aplicación.

36 Castillo de Bobadilla, Política, cit., V, I, p. 246.

37 Ídem, II, VII, pp. 7-8.

38 Ídem, V, III, pp. 28-29 y 44.

39 Ídem, III, XI, p. 34. 
Solórzano no era, en cambio, tan concreto en el extenso capítulo que consagraba al proceder de oidores y ministros de las audiencias indianas. ${ }^{\mathbf{4 0}}$ Sus repetidas advertencias no llegaban a establecer - con la nitidez que apreciamos en el autor anterior - las fuentes a las cuales debía acudir el magistrado aunque su testimonio también apoya el criterio dominante que venimos comprobando. El objetivo era juzgar conforme a razón, equidad y justicia. Debía admitirse en el tribunal la variedad de opiniones y la libertad para disentir pero el juez no debía decidir jamás "por solo su ingenio y capricho, apartándose de la escrita y bien cimentada y practicada jurispericia". Añadía que "estamos obligados a seguir, cuando juzgamos o aconsejamos las opiniones comunes y más aprobadas y probables". La doctrina de los autores aparecía nuevamente, esta vez en Solórzano, como base de sustentación de la labor del juez.

Como se habrá observado, los textos escogidos en este apartado convergen en destacar de modo constante la presencia de dos fuentes principales: ley y doctrina. En ellas se formaba el letrado, a ellas acudía el abogado, en ellas se fundaba el juez. A veces se mencionaba expresamente a la costumbre, la cual, aunque menos citada, nunca era rechazada. También encontramos precisado en Castillo de Bobadilla el recurso a la razón y a la epiqueya, que sustentaba el arbitrio judicial, tan difundido y aceptado en la práctica. Según apreciamos, la doctrina no sólo era una fuente de primera línea, de la cual no se podía prescindir, sino que ella apuntaba con fuerza directiva en la aplicación del derecho a los casos o situaciones planteados. Bien vale ahora recordar, subrayándolas, esas ponderadas palabras de Solórzano que compelían al juez a atenerse a "la escrita y bien cimentada y practicada jurispericia", que se constituía así, al mismo tiempo, en norte y límite de su horizonte.

\section{Opiniones y autores bajo la lupa crítica de profanos y letrados}

Las opiniones de los autores no merecían sólo estimación. También recibían críticas. El predominio de la jurispericia solorciana no era pacífico. Desde el mismo siglo XVI se desplegó un movimiento que revelaba la insatisfacción de profanos y aun de letrados ante la incertidumbre y confusión que oca-

40 Juan de Solórzano, Política Indiana, Madrid, 1647, V. VIII (utilizo la edición Madrid, 1776). 
sionaba el cúmulo de opiniones, frecuentemente discordantes. ${ }^{41}$ Los tonos y enfoques eran diversos pero por lo general coincidían en avizorar la solución en el dictado de pocas leyes, breves y claras. Se apuntaba pues en la dirección de establecer una "jurisprudencia legal". Esto mismo ya lo hemos apreciado, páginas atrás, en el testimonio ambiguo del licenciado Barreda. Acudamos a algunas muestras de esa postura, empezando por los profanos.

Aunque es bien conocida resulta de mención inexcusable aquella estrofa que reproduce el Cancionero de Baena, atribuida a Juan de Mena:

Viene el pleito a disputación: allí es Bartolo e Chino, Digesto, Juan Andrés e Baldo, Enrique, do son mas opiniones que uvas en cesto. ${ }^{42}$

O aquella otra imploración del poeta castellano que, luego de quejarse de la multitud de autores, exclamaba:

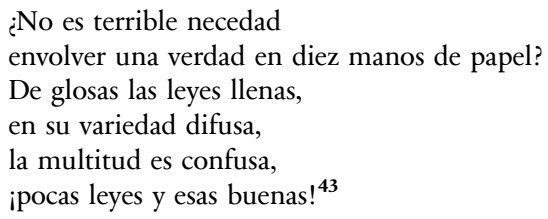

Al sostener que los letrados "han hecho oscuro lo claro de las leyes con comentos" un escritor de fines del XVII se complacía en recordar la decisión de quien, abrumado de tanta literatura, había entregado "los Civiles a encender el fuego, los Criminales a freír pescado" ${ }^{44}$

Esta postura crítica quedaba también estampada en aforismos, como éstos: "La paz y la quietud, cuelgan de pocas leyes bien gobernadas; y de los muchos intérpretes, la guerra y la confusión"; "La muchedumbre de opiniones suele al público gobierno ser dañosa"; o esta última más directa:

41 Sobre este movimiento crítico, véase un panorama general en Alejandro Guzmán Brito, "Crítica al derecho como presupuesto de la fijación en torno al primer tercio del siglo XIX”, en REHJ, V, 1980, pp. 271-286.

42 Su texto reproducido en García-Gallo, Manual, cit., t. II, núm. 227.

43 La Hoz y Mota, El montañes Juan Pascual (citado por José María Pemán, "La idea de justicia en las letras clásicas españolas", en Revista de Derecho Español y Americano, núm. 15, Madrid, 1967, p. 17).

44 Andrés Ferrer de Valdecebro, El templo de la fama, Madrid, 1680, pp. 119 y 131. 
"Puesta sobre buen seso la experiencia no ha menestar a Bartulo ni a Baldo" ${ }^{45}$ Escritores políticos, como Saavedra Fajardo, Fernández de Navarrete y, más tarde, Portocarrero empujaban en la misma dirección: abreviar pleitos, reducir multitud de leyes, desterrar las opiniones dudosas y oscuras. ${ }^{\mathbf{4 6}}$ Para Portocarrero, las opiniones de los autores provocaban "la dilación en los pleitos y el arbitrio de los juicios, ${ }^{, 47}$ con lo cual introducía los elementos de la crítica dieciochesca.

Dentro de esta ebullición de ideas, pero aplicado a una situación distinta con ingredientes peculiares, puede recordarse que cuando Fray Gerónimo de Mendieta exponía la inadecuación del Derecho letrado a los aborígenes americanos, apoyaba su postura afirmando que "ni Justiniano hizo leyes, ni Bartulo ni Baldo las expusieron para este nuevo mundo y su gente". ${ }^{8}$

Uno de quienes más tempranamente expuso su posición crítica ante los autores e hizo al mismo tiempo una nueva propuesta fue el humanista Pedro Simón Abril. A fines del siglo XVI proponía que el Derecho se encerrase en un nuevo cuerpo de leyes, en el cual se recogiesen las doctrinas y se decidiesen las cuestiones controvertidas, debiendo cesar en adelante todo comentario, glosa e invocación a los doctores. Los abogados sólo podrían alegar ley, costumbre o razón" ${ }^{49}$

Estos ejemplos son - según creo - suficientes para advertir que el centro de la crítica al Derecho por parte de los profanos era la doctrina de los autores. Señal clara de su presencia dominante, según lo hemos comprobado anteriormente. Dentro de esa crítica, aunque no establecía distingos, los autores del Derecho común eran los destinatarios de las reprobaciones. En este sentido no era arbitraria la mención de ciertos doctores sobresalientes, como Bartolo y Baldo, para simbolizar ese abigarrado cúmulo de opiniones

45 Johquín Setanti, Centellas de varios conceptos, fs. 1; y Avisos de amigos, fs. 74 y 75 . Ambos escritos en B. Arias Montano, Aforismos, Barcelona, 1614.

46 Sobre los dos primeros, véase Petit, "Derecho común y Derecho castellano...”, cit., pp. 191-192.

47 Pedro Portocarrero y Guzmán, Teatro monárquico de España, Madrid, 1700, pp. 171-172.

48 Carta a Fray Francisco de Bustamante, Toluca, 1 de enero de 1562. Su texto en Joaquín García Icazbalceta, Nueva colección de documentos para la historia de México, 1886, t. I, p. 19.

49 Apuntamientos de cómo se deben reformar las doctrinas y la manera de enseñarlas... (1589), en Biblioteca de Autores Españoles, t. 65, Madrid, 1953, p. 299. 
que se pretendía desterrar. La crítica encontraba también sustentación sólida en una tendencia que se insinuaba ya en escritores del seiscientos: una mayor inclinación hacia la valoración de las razones en detrimento de las autoridades.

Entre los juristas de la época también podemos encontrar actitudes coincidentes con la línea anterior. Pero se trata de un movimiento que no hizo mella en el criterio entonces dominante. Las propuestas tendían a producir un cambio en la jurisprudencia mediante la limitación y aun la supresión del recurso a los doctores. Uno de los más empeñados en esta dirección fue Tomás Cerdán de Tallada, quien sostenía la necesidad de buscar "un diferente orden y estilo del hasta ahora utilizado" para cortar la multitud de pleitos y abreviar su duración. Consideraba que la existencia de tantas opiniones entre los doctores era uno de los factores que producía ese daño y en consecuencia proponía en 1607 volver a la vieja solución de la ley castellana de 1499, derogada en Toro: que se siguiesen las opiniones de Bartolo, Baldo, Juan Andrés y el Abad Panormitano, incorporándose también el recurso a la Glosa y declarando que todo ello fuese a falta de ley castellana. ${ }^{\mathbf{5 0}}$

Otros coetáneos de Cerdán eran más restrictivos en la propuesta. Gerónimo de Zevallos sostenía como regla que el rey debía "reducir la variedad de opiniones contrarias a leyes para que cesen las guerras civiles de los pleitos" ${ }^{51}$ Lope de Deza, en una postura reformadora más avanzada - de la cual me he ocupado en otra occasion - postulaba no sólo que las opiniones contrarias de los doctores se redujesen a reglas legislativas ciertas y claras en un nuevo cuerpo de leyes, sino que en el futuro se prohibiese a los autores la interpre-

50 Veriloquium en reglas del Estado..., Valencia, 1604, pp. 200 y 225; y [Discurso para que no haya tantos pleitos], Madrid, 1607, fs. s/núm. Sobre la vida de este jurista y el sentido de su obra, véase Teresa CANet Aparisi, Vivir y pensar la política en una Monarquía plural. Tomás Cerdan de Tallada, Universitat de Valencia, 2009, especialmente pp. 152 y ss.

51 Arte real para el buen gobierno..., Toledo, 1623 (Tabla de los aforismos y reglas..., 81). De modo más extenso se ocupa en fs. 163-171. Ya con anterioridad había expuesto esta idea en su libro Speculum practicarum et variarum quaestionum opinionum communium contra comunes (1599), del cual se ocupa Alejandro Guzmán Brito en "La decisión de controversias jurisprudenciales como una de las operaciones codificadoras en el pensamiento de Andrés Bello" que corresponde a la serie de estudios sobre la historia de la fijación del derecho civil en Chile, durante la República. Publicado en Actas del Congreso Internacional 'Andrés Bello y el Derecho', Santiago de Chile, 1982, pp. 217-218. 
tación de las mismas. ${ }^{52}$ Otro escritor, Juan Sancho Ponce de León - probablemente del mismo siglo - proponía reunir en un cuerpo la ley acompañada de la glosa más significativa. ${ }^{53}$

Este conjunto representativo de aspiraciones reformistas - la mayoría de principios del XVII - apuntaba pues a un considerable cambio de la jurisprudencia, adoptando como punto de partida de la reforma a la doctrina de los autores. Adviértase que Cerdán quería volver a implantar una "ley de citas". Deza, a su vez, incorporaba las doctrinas a un cuerpo de leyes y sólo desde ese momento quedaría vedada toda labor de interpretación. Ponce de León también incorporaba la labor doctrinal a un futuro cuerpo legal. Ninguno pues prescindía de esta fuente del derecho, ninguno de ellos estaba dispuesto a echar al fuego dichos libros. Era una nueva prueba de su posición directiva en el Derecho. Las propuestas de estos juristas reformadores no tuvieron inmediata acogida aunque eran un anticipo del despliegue que observaremos siglo y medio después.

Según se puede apreciar, en el movimiento crítico que hemos esbozado, tanto entre profanos como entre letrados, aparecían también a la cabeza dos fuentes principales: leyes y autores. Por lo general, la inclinación era favorable a la primera de ellas. Se estaba incubando el clima dieciochesco.

\section{Siglo XVIII: virulencia de la crítica y subsistencia de opiniones y autores}

En el siglo XVIII - sobre todo en la segunda mitad - se agudizó el movimiento crítico que acabamos de observar en las centurias precedentes. Con mayor nitidez el ataque se dirigió contra la jurisprudencia casuista dominante, siendo blancos preferidos la doctrina de los autores y el arbitrio de los jueces. Aunque aquel movimiento era vasto, compuesto de diversas líneas y expuesto en tonos diferentes, todos convergían en desterrar del orden jurídico a nuestra fuente de derecho.

52 Víctor Tau Anzoátegui, “El 'Juicio de las leyes civiles' de Lope de Deza. Una obra crítica y reformadora en tiempos de Felipe III", en RHD, núm. 13, 1985, pp. 509-518.

53 Sánchez Bella, “Los comentarios..., cit., pp. 430-431. 


\section{Una ideología antijurisprudencial}

A la cabeza de esta tendencia encontramos lo que se ha denominado "ideología antijurisprudencial”, propia del pensamiento ilustrado y revolucionario, en la cual se percibe un subido matiz político. ${ }^{54} \mathrm{La}$ doctrina de los autores era considerada como uno de los baluartes que había permitido a los juristas monopolizar el conocimiento del Derecho y la administración de justicia, asegurándose de este modo un enorme poder social y económico. Para modificar tal estado de cosas, se postulaba la elaboración de cuerpos legales, comprensivos y claros que, dando certeza al Derecho, liberasen a la sociedad de la opresión de los juristas. De tal modo se suplantaba un ordenamiento controvertido y oscuro, dominado por la doctrina de los autores y manipulado por el arbitrio de los jueces. Autores y jueces debían quedar separados de la creación jurídica y sometidos a la ley. Aquellos en la labor de comentario, éstos en su estricta aplicación. Esta idea quedó plasmada ya en el primer esfuerzo codificador en sentido estricto, el Código de Prusia de 1794, donde se estableció que en los pronunciamientos judiciales no se haría mérito de las opiniones de los jurisconsultos ni de las decisiones anteriores. También tiene sustancioso precedente en el mundo hispano del último tercio del siglo. En 1772, al darse las Ordenanzas Militares, se estableció que no se pudiesen interpretar, debiendo observarse literalmente. Al año siguiente, el Consejo de Indias consideraba que el comento de las leyes reales indianas era inútil y perjudicial, dictamen que llevó al Real Decreto de 9 de mayo de 1776 que dispuso que "nunca se permita la glosa o comento de ellas" ${ }^{\text {55 }}$ Este mismo criterio prohibitivo se reiteró al sancionarse en $1792 \mathrm{el}$ Nuevo Código. 56

Acudamos a algunas páginas de escritores - juristas o no - que, bajo formas literarias grandilocuentes, difundieron por Europa y América la idea que sustancialmente acabo de enunciar. Así empezaba Cesare Beccaria su

54 Un panorama europeo, con particular énfasis en Italia, véase en Adriano Cavanna, Storia del diritto moderno in Europa. Le fonti e il pensiero giuridico, Milano, 1979, t. I, pp. 307 y ss. También Guido Fassó, Historia de la Filosofía del Derecho, edición española, Madrid, 1979, t. II, pp. 251 y ss.

55 Sánchez Bella, “Los comentarios...”, cit., pp. 430-431.

56 Véase Antonio Muro Orejón, Estudio general del Nuevo Código de las leyes de Indias, pp. 43-45 (publicado en el Homenaje al Dr. Muro Orejón, vol. II, Facultad de Filosofía y Letras de la Universidad de Sevilla, Sevilla, 1979). 
libro De los delitos y de las penas: "Algunos restos de leyes de un antiguo pueblo conquistador, que un príncipe reinante en Constantinopla ha doce siglos hizo recopilar, entremezcladas luego con los ritos longobardos y envueltas en farroginosos volúmenes de intérpretes privados y oscuros, forman aquella tradición de opiniones que en gran parte de Europa lleva todavía el nombre de leyes. Y es cosa tan funesta como corriente en nuestros días, que una opinión de Carpzovio, un uso antiguo señalado por Claro o un tormento sugerido con iracunda complacencia por Farinaccio, sean las leyes a las cuales obedecen con seguridad quienes al regir la vida y la fortuna de los hombres debieran temblar". 57 Párrafo conocido y ampliamente difundido entonces, en el cual el recordado Marqués enjuiciaba a la jurisprudencia europea de su tiempo. Según se advierte, el centro de la crítica era la autoridad de las opiniones.

En un estilo apocalíptico también, Cayetano Filangieri - otra de las celebridades -, en un juvenil escrito de 1774, nos ofrecía esta aterradora descripción: "Un gran número de intérpretes oscuros, confusos y opuestos casi siempre entre sí, que produjeron los siglos de la ignorancia forman el caos infinito de opiniones que hacen tan dudosa e incierta la jurisprudencia de la mayor parte de Europa". Y agregaba: "Nuestros tribunales particularmente han presentado hasta estos días un espectáculo que debían mover a compasión el corazón sensible de un filósofo. Era sin duda cosa vergonzosa en estos siglos ilustrados ver un magistrado inclinar la cabeza al solo nombre de Bartulo, tener por delito oponerse a un párrafo de Ageta, y oír con tanta veneración una sentencia de Claro, como en otro tiempo hubiera podido oír un Espartaco los oráculos de la sacerdotisa de Apolo....YY aun continuaba de este modo: "La piedra angular que sostiene el arbitrio judicial es la autoridad de los doctores: la diversidad de sus doctrinas da un velo al magistrado con que cubrir sus opresiones; por lo que el inmortal Leibniz aconsejaba fuesen quemados todos los farraginosos volúmenes de estos intérpretes" ${ }^{58}$ Tan denso contenido acusatorio tenía un final bien sorprendente. Era difícil lograr una mejor caricatura de la jurisprudencia que infundiera espanto.

57 Texto según edición crítica bilingüe publicada por Francisco P. Laplaza, Buenos Aires, 1955, p. 173. Esta página no apareció en las primeras ediciones.

58 Cayetano Filangieri, Reflexiones políticas sobre la ley de Fernando IV, Rey de las Dos Sicilias, que tiene por objeto la reforma de la administración de justicia. Obrita incluida en Ciencia de la legislación, t. IV, Madrid, 1813, p. 242. 
Estos cuadros dantescos se irradiaban en la sociedad hispana a través de sus escritores, en obras de ficción o ensayo. Así por ejemplo, el conde de Cabarrús asemejaba la jurisprudencia a "una cueva humedecida en sangre, donde cada pasión atormenta y devora a sus víctimas", prefiriendo "la libertad, los riesgos y los bosques de la naturaleza" antes que la subsistencia de "tan monstruosa tiranía". Esa jurisprudencia era para él "una mole inmensa e incoherente de teocracia, republicanismo, de despotismo militar, de anarquía feudal, de errores antiguos y de extravagancias modernas; aquella mole de treinta y seis mil leyes, con sus formidables comentadores." ${ }^{59}$ A su vez, José Cadalso, hablando por boca de uno de sus personajes, decía que a medida que se multiplicaban los autores "se ha ido oscureciendo la justicia". Y agregaba: "A este caso, tan peligroso me parece cada nuevo escritor de leyes como el infractor de ellas: tanto delito es comentarlas como quebrantarlas. Comentario, glosas, interpretaciones, notas, etc., suelen ser otros tantos ardides de la guerra forense. Si por mi fuera, se debiera prohibir toda obra nueva sobre esta materia por el mismo hecho" ${ }^{\mathbf{6 0}}$

La fuerza literaria de estas descripciones y la nombradía de sus autores hacen innecesario recurrir a otros testimonios para apreciar la profundidad y extensión de la crítica dirigida contra la opinión de los autores y contra el arbitrio de los jueces. Unos y otros debían quedar - como he dicho - sometidos al poder supremo de las leyes. Los autores aparecían como corruptores de las leyes. Como decía el político Macanaz "tenemos muchas leyes, muy justas, arregladas y santas; pero para cada una hay veinte autores, interpretándolas cada una de diferente manera" ${ }^{61}$ Otra pluma, desde Lima, consideraba también que los autores ofendían "lo que literalmente con sabio prudentísimo acuerdo, está determinado y establecido" en las leyes. ${ }^{\mathbf{2}}$

El mundo de las imágenes acudía también en apoyo de estas descripciones literarias, que luego los juristas recogían complacientes. La figura del "labe-

59 Conde de Cabarrús, Cartas sobre los obstáculos que la naturaleza, la opinión y las leyes oponen a la felicidad pública, Vitoria, 1808. Edición consultada, Madrid, 1933, pp. 81 y 95-96.

60 Cartas marruecas (1789), carta VIII, Edición Austral, Buenos Aires, 1952, pp. 30-31.

61 Melchor de Macanaz, “Auxilios para bien gobernar una monarquía católica...”, en A. Valladares de Sotomayor, Semanario erudito, Madrid, 1787, t. V, pp. 236-237.

62 Francisco Javier Álvarez de Lamas, Código Hispánico, Católico, Fernandino (1758), Mss. s/ p. (Archivo General de Indias, Indiferente General, 1650). 
rinto" era una de las tantas para representar a esa jurisprudencia oscura, confusa. Fue acaso una de las que tuvo más eco. Los autores - se suponía - habían creado ese laberinto para que en su interior se perdiese quien estaba adentro, o no pudiese penetrar quien estaba afuera, según fuese la preferencia de cada escritor. No faltaba empero quien, discrepando con esa difundida imagen, estimaba que eran precisamente los doctores quienes auxiliaban a salir del laberinto de una cuestión intrincada. ${ }^{63}$

No estaba ausente en este haz de argumentos con que se atacaba a la doctrina de los autores, la contribución de la utopía, tan del gusto de los hombres de la época. Así un escritor recogía un cuento según el cual un Rey del Congo tuvo una actitud bien aleccionadora. Al recibir como obsequio del rey Don Manuel de Portugal "varios libros de Derecho y de sus Doctores" le respondió que estimaba el regalo "pero quemó los libros y remitió los D.D. con la respuesta, que no harían otra cosa, que revolver los sesos de sus vasallos, que vivían en paz con el dictamen solo de la razón y buen sentido" ${ }^{64}$

\section{Otras expresiones y matices de la crítica antijurisprudencial}

Sin desdeñar la acción demoledora de estos destellos literarios, es conveniente que reparemos en otras expresiones de esta crítica antijurisprudencial. Expresiones menos espectaculares pero acaso tanto o más efectivas en la destrucción del reinado de opiniones y autores. Expresiones que en algunos casos precedieron a aquellas que hemos conocido en páginas anteriores. Una persistente prédica, que enaltecía el argumento de razón sobre el de autoridad, que exaltaba a las leyes reales sobre los autores, que postulaba el ideal de un código sistemático, marcaba la huella de un cambio profundo. La crítica racional a la multitud de opiniones e intérpretes se matizaba a veces con el reconocimiento hacia su labor y con la propuesta de incorporar sus doctrinas al proyectado código. No dejaba de estar presente una línea sutil que, separando los autores hispanos de los de Derecho común, excluía a aquéllos de la condena. Acudamos a verificar, desde distintos ángulos y utilizando algunas muestras escogidas, la fuerza y diversidad de estas expre-

63 José M. Mariluz Urquijo, “Maziel, jurista del setecientos”, en RHD, núm. 16, 1988, p. 189.

64 D.A. Sz y St ${ }^{\circ}$, Discursos crítico políticos sobre varias materias de Estado y Gobierno (1775), mss. En Miscelánea de Ayala, t. XXXIII, fs. 301 (Biblioteca de Palacio, Madrid, núm. 2846 bis). 
siones que convergían en el embate final contra la doctrina de los autores. He elegido para ello dos obras representativas de esta postura, que alcanzaron buena difusión en el ámbito hispano: el ensayo Defectos de la jurisprudencia del italiano Ludovico Antonio Muratori, publicado en 1742; y los Discursos críticos sobre las leyes y sus intérpretes del español Juan Francisco de Castro, editado en 1765. El libro de Muratori fue traducido al castellano en $1794{ }^{65}$

Para Muratori la multitud de opiniones y disputas era el mayor mal que afectaba a la jurisprudencia, dando lugar a que los jueces hiciesen valer su arbitrio. Consideraba que la medicina y la teología moral estaban igualmente embrolladas con innumerables opiniones, pero allí no era posible o deseable el cambio, que si se debía hacer en el Derecho. Para ello era preciso que "los Soberanos metan la hoz hasta las raíces, cortando cuanto puedan las controversias y mandando por medio de nuevas Leyes o Estatutos lo que debe observarse inviolablemente en lo sucesivo en los Tribunales" ${ }^{66}$ Su propuesta concreta consistía en formar un código - que tuviese fuerza de ley en donde se reuniesen las opiniones comunes que se hallasen en práctica en cada país, desterrando así la multiplicación de dictámenes y disputas. La idea vertebral de la obra descansaba sobre los mismos postulados sustentados por la ideología antijurisprudencial en franco avance: exaltación de la ley, recelo ante el arbitrio judicial y eliminación de la controversia de opiniones. Pero había en Muratori un ingrediente central que daba un sesgo algo diferente a su propuesta: la estimación sustancial de las opiniones comunes, cuyo valor era rescatado y preservado a través de un código, aun a costa de convertirlas en fósiles. La propuesta en este sentido no era nueva para el mundo hispano...

En la obra crítica de Castro - que he tenido oportunidad de examinar con más detención en otra ocasión ${ }^{67}$ - se encuentran junto a ciertos párrafos de estilo inflamado contra opiniones y autores, otras páginas y juicios de mayor ponderación en los cuales se reconocía el mérito y la utilidad de los intér-

65 Utilizo esta edición: Luis Antonio Muratori, Defectos de la jurisprudencia, Madrid, 1794. Hay interesantes aplicaciones del texto a la situación española a cargo del traductor Vicente María de Tercilla.

66 Ídem, pp. 11-13 y 263-264.

67 Víctor Tau Anzoátegui, "El pensamiento español en el proceso de la codificación hispanoamericana: los 'Discursos críticos' de Juan Francisco Castro', en REHJ, V, 1980, pp. 385 yss. 
pretes. Así, desde su óptica, veía indecisiones, mutabilidades y contradicciones en el ámbito de las opiniones que exasperaban su temple racional. Ello lo llevaba a contemplar la jurisprudencia como "un campo sombrío, en que no hay amenidad alguna, cubierto todo de rudas espinas, sin conceder entrada sino a quien con hacha y azadón en la mano, con mucho sudor, pena y fatiga se franquea el camino...”. Pero también reconocía que a la ley le era necesaria "una prudente interpretación" y que en las obras de esos autores siempre se encontrarán "ricos materiales para la fábrica del nuevo y luminoso edificio que deseamos", que era un metódico cuerpo de derecho legal. A la hora de alcanzar ese objetivo "será tiempo de despedir nuestros trabajosos conductores" e impedir que "algún particular se atreva a escribir sus pensamientos y opiniones sobre las leyes".

Cuestión decisiva para nuestro tema es la permanente fricción - en la teoría y en la práctica - que puede advertirse entre los argumentos de razón y de autoridad. El enfoque teórico venía ya dando prioridad al primero pero en la práctica la fuerza del segundo era imbatible. Piquer, al promediar la centuria, mostraba su asombro ante el poco uso de la razón que hacían médicos y letrados, cuando para "probar un asunto citan doscientos Autores hacinados, y lo suelen hacer para confirmar una verdad notoria de las que llamamos de Pero Grullo...” ${ }^{\mathbf{6 8}}$ Otro escritor encarecía la necesidad de hacer una prudente crítica de las opiniones para evitar su insustancial crecimiento. No basta - agregaba - que un moralista exprese cuántos autores la apoyan sino que "debe buscar y saber, en que se funda la opinión y si flaquea o no su fundamento" y además determinar si subsiste o no la razón grave que le dio sustento" ${ }^{69}$ Por fin, un jurista, al recoger los frutos de la nueva postura que se iba imponiendo, estampaba esta aseveración: "La razón siempre persuade, por más que muchos contradigan: la autoridad puesta en duda, no puede inclinar el juicio".70

Otra cuestión determinante que es preciso al menos esbozar, es el enfrentamiento que se produjo entonces entre Leyes y Autores, aquéllos dos modos de creación del derecho tan repetidamente tratados en páginas anteriores. La

68 Andrés Piquer, Lógica moderna..., Valencia, 1747, p. 110.

69 Antonio José Rodríguez, Nuevo aspecto de teología médico moral y ambos derechos..., Zaragoza, 1742, t. I, pp. 12-14 y 25-26, y prólogo.

70 Pablo Mora y Jaraba, Tratado crítico, Los errores del Derecho civil y abusos de los jurisperitos..., Madrid, 1748, p. 28. 
exaltación de las leyes reales en detrimento de los autores nos lleva a escoger la figura de un interesante jurista valenciano, con actuación en los años centrales de la centuria: Joseph Berni. Fue uno de quienes defendió con más vigor esas ideas y nada mejor que extraer algunas muestras representativas de su pensamiento. Ya en una obrita de 1738 sostenía que "procede mal el Abogado que sólo se funda en la común de los autores, sin contar con las leyes del Reino". Sólo se debía dar crédito a los autores apreciando sus doctrinas "cuando fielmente correspondan a las Leyes que citan". Desalentaba a los abogados a gastar mucho en libros de doctrina, sosteniendo que en España "gracias a Dios tenemos las leyes Reales tan recogidas, y puestas en orden, que con poco trabajo se halla Ley terminante para cada cosa: luego es por demás ir a buscar el agua en los charcos de los Autores, teniéndola tan a mano en la pura fuente de las leyes Reales”. Como si después de sus afirmaciones y de esta alegoría pudiese quedar aún alguna duda, Berni afirmaba poco más adelante que por más que todos los autores "digan ser blanco, si la ley Real dice ser negro, a ella debemos estar”. En su propósito de desacreditar a los doctores, Berni dedicaba un extenso capítulo a demostrar la falsedad de algunas citas de autores modernos para que los abogados no se fiasen de ellos. ${ }^{71}$ En otra de sus difundidas obras, Berni recomendaba al lector que huyera del "laberinto de los autores y se acogiera al estudio de las leyes reales ya que "ellas te sacarán de todo". Pero páginas más adelante se veía obligado a reconocer que, aunque no fuese conforme a las leyes de España, en la práctica se acudía a las romanas y a los autores. ${ }^{72}$

Me parece elocuente este ejemplo por la nitidez con que definía la cuestión Las Leyes reales eran presentadas como ordenadas y abarcadoras. Las opiniones, además de inciertas, eran innecesarias. Sólo merecían aprecio cuando estaban conformes a la ley. La resolución de ésta era decisiva. El ejemplo no deja tampoco de tener interés si se le mira teniendo en cuenta la difusión que alcanzaron las distintas obras de Berni en los niveles docente y práctico. Finalmente, no puede dejarse de subrayar la confesión final, patente testimonio de la realidad.

El desequilibrio entre Leyes y Autores, que planteaba esta dura crítica lo encontramos reflejado ya en obras de la época. Veamos sólo algunos ejem-

71 Joseph BeRni, El abogado instruido en la práctica civil de España (1738), edición consultada, Valencia, 1763, pp. 28-31 y 37 y ss.

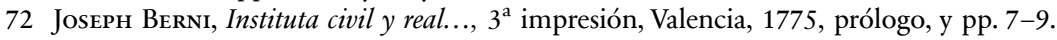


plos de los muchos que podrían cosecharse. Rivadeneyra y Barrientos, en su libro sobre el Patronato, decía al lector que había reducido la cita a "muy pocos Autores" y que, en cambio, había procurado "siempre confirmarte la doctrina, que se te da con la ley de Indias, y tras ella el Texto Canónico, la Bula Pontificia, o la Decisión Conciliar, que son las reglas, que te deben dejar más satisfecho que todas las opiniones." ${ }^{73}$ A su vez, bajo la idea de que habían de observarse puntualmente las leyes, el autor de la obra Década legal consideraba que los jurisconsultos merecían aprecio "por su conformidad a la Legislación y por su diligencia en ilustrarla", quitándole toda autoridad propia. ${ }^{74}$ En fin, en un Discurso sobre la observancia de las leyes del Reino se puntualizaba la necesidad de que tanto en las aulas como en los tribunales se prestase más atención a dichas leyes y no se dejase todo en manos de los autores. ${ }^{75}$ Esta misma tendencia parece percibirse en la mayor parte de los juristas que escribieron glosas o comentarios a la Recopilación de 1680.

Por último, cabe abordar una nueva cuestión que se planteó a todo lo largo de la centuria, que requiere tratamiento separado y de la cual sólo anticiparé alguna idea, acompañada de unos pocos testimonios. Dentro de este combate que se libraba implacablemente contra la doctrina de los autores en general, se puede apreciar que en determinadas ocasiones surgía un distingo entre los autores hispanos y los del Derecho común. El ataque era especialmente dirigido contra estos últimos y particularmente contra los cultivadores del Derecho civil, formando parte de una extendida crítica política que discriminaba entre Derecho romano y Derecho real. ${ }^{76}$ Ambas cuestiones aparecían a veces superpuestas. Algunos ejemplos pueden ser ilustrativos.

Empecemos con el muchas veces citado auto acordado de 1713 del Consejo de Castilla. La medida carecía de alcance indiano pero, a los fines que nos proponemos, resulta elocuente. Se establecía en dicho auto que en con-

73 Antonio Joaquín de Rivadeneyra y Barrientos, Manual compendio de el Regio Patronato Indiano, Madrid, 1755, Prólogo.

74 Ramón Cortines y Andrade, Década legal..., Madrid, 1786, pp. 102-103.

75 Escrito anónimo, fechado en Madrid, 31 de enero de 1788, Mss. en Miscelánea de Ayala, t. XXXIX, fs. 222 y ss. (Biblioteca de Palacio, Madrid, núm. 2852).

76 Véase sobre esta cuestión, Riaza, El derecho romano y el derecho nacional, cit.; Peset Reig, "Derecho romano y derecho real", cit.; y Abelardo Levaggi, "Derecho indiano y Derecho romano en el siglo XVIII", en Anuario Histórico-Jurídico Ecuatoriano, t. VI, Quito, 1980, pp. 269-309. 
travención del orden legal existente "se sustancian y determinan muchos pleitos en los tribunales de estos reinos valiéndose para ello de doctrinas de libros y autores extranjeros, siendo mucho el daño que se experimenta de ver despreciada la doctrina de nuestros propios autores, que con larga experiencia explicaron, interpretaron y glosaron las referidas Leyes, Ordenanzas, Fueros, usos y costumbres de estos reinos". También admitía que estaba difundido el criterio de dejar de lado ciertas leyes del reino y conceder mayor estimación a las civiles y canónicas. El Consejo finalmente encargaba a los tribunales del reino "observar las leyes patrias con la mayor exactitud". Si nos atenemos exclusivamente a esta indicación final se percibe en este auto castellano una nítida preferencia legal, pero si examinamos el texto completo encontramos que el ataque principal estaba dirigido contra el Derecho común y contra sus autores. En efecto, no sólo hacía una clara defensa - y hasta elogio - de "nuestros propios autores", sino que en su texto invocaba glosas de Villadiego y de Gregorio López en un alarde que contribuía a acentuar aún más ese distingo. Lo que prevalecía en este auto era la defensa del ordenamiento propio y de las regalías del rey, y en ello agrupaba a leyes y autores. Antes que condenar, o recomendar la exclusión, de la doctrina castellana, se la mencionaba elogiosamente en un implícito consejo a seguirla.

Mora y Jaraba, en su conocido planteo crítico, atribuía toda la contrariedad de dictámenes a la confusión del Derecho civil, mientras que - decía era muy pocas las opiniones contrarias de los autores en el Derecho real. ${ }^{78}$ Más allá de la certeza del juicio, con esta afirmación se procuraba eximir de la generalizada condena a los autores hispanos. En esta misma dirección cabe volver a Berni, cuya censura a los doctores tampoco se extendía a los españoles. Valga recordar que este jurista editó las Partidas, despojada de la glosa romanista de Gregorio López, con sólo menciones de autores españoles, a quienes consideraba que podía acudirse en última instancia para la inteligencia de las leyes. ${ }^{79}$

Esta tendencia no alcanzó a desplazar a los doctores más famosos. Fernández de Mesa reconocía en 1747 que se juzgaba más "por las glosas, por

77 Autos acordados, Madrid, 1772, II, I, 1.

78 Mora y Jaraba, Tratado..., cit., p. 206.

79 Apuntamientos sobre las leyes de Partida, Valencia, 1759, t. I, p. 9. 
Bartulo y Baldo, y los autores que a ellos siguen” que por otros más modernos" ${ }^{\mathbf{8 0}}$ Como es sabido el Derecho romano mantuvo su vigorosa presencia entre los juristas. Pero posiblemente la distinción apuntada contribuyó a realzar la autoridad de algunas obras jurisprudenciales castellano-indianas. Es una hipótesis que merecería ser examinada con alguna distinción.

\section{Los autores en la actividad de abogados y jueces}

Bien podría creerse, por el tono de ciertas censuras o por la insinuación racional emergente de otros escritos, que los juristas abandonaron prontamente la estimación e invocación de las opiniones y de las obras jurisprudenciales. Pero no fue así, Pese al caudal de expresiones condenatorias, la doctrina de los autores subsistía airosamente, tanto en la didáctica jurídica como en la actividad profesional y en el modo de juzgar. Prescindir de la misma era crear un enorme vacío, imposible de cubrir de otra manera, en la vida de esa jurisprudencia casuista en proceso de transformación. Constatemos cuál era la situación.

La presencia en abundancia de esas obras de jurisprudencia en las bibliotecas de los letrados de la época y las reediciones de las principales apoyan, sin duda, esa apuntada subsistencia. A propósito de las nuevas impresiones que en la década del setenta se hicieron, entre otros, de libros de Solórzano Política Indiana y De Indiarum Iure -, de la Política de Castillo de Bobadilla o de la Curia Filípica de Hevia Bolaños ¿puede pensarse que se hacían para satisfacer la erudición histórica o por curiosidad literaria?

No faltaban quienes estimaban la función que cumplían los autores, aun dentro de un clima adverso a su labor. El oidor Simón de Anda y Salazar decía en 1756 que "los escritores son las abejas de la república: ellos velan, para que los demás duerman: trabajan para que los otros coman el pan sin trabajo". Bajo esta introducción dispensaba su elogio a un comentarista de las leyes indianas que había logrado - según él - "compilar en breve volumen, leyes, jurisconsultos y doctrina por lo infinito dispersas"

80 Tomás Manuel Fernández de Mesa, Arte histórica y legal de conocer las fuerzas y uso de los derechos nacional y romano en España...(1747), edición utilizada, Madrid, 1802, p. 245.

81 Carlos de Alurralde, Los 'Comentarios a la Recopilación de Indias' del licenciado Juan del Corral Calvo de la Torre, Buenos Aires, 1951, p. 51. 
En la formación de los letrados se manifestaban las nuevas tendencias que exaltaban el Derecho real en detrimento del común y se inclinaban por una instrucción sistemática. Pero los autores no desaparecían... Ello provocaba que Juan Pablo Forner, en el último tercio del siglo, se quejara porque el estudio se hacía no en "las leyes puras y bien meditadas" sino "en la indigestión portentosa de una infinidad de volúmenes farraginosos".82

Aún más interesantes son otros dos testimonios, de raíz reformista, que mantenían dentro de la instrucción jurídica a los autores, aunque esta vez con preferencia hacia los "regnícolas". Uno es el "Curso Hispánico Regio Legal”, proyectado por Juan Antonio Llorente en 1785. El estímulo reformador y la orientación sistemática le llevaron a dar a las leyes reales el lugar principal, sin desdeñar la utilización de los autores regnícolas en aquellos puntos no decididos por el legislador. Para esto precisamente estimaba necesario preparar a los estudiantes en el ejercicio escolar de la disputa. Aunque Llorente se proponía omitir las cuantiosas citas de doctores y de atender más a la razón que a la autoridad, no excluía de su consideración a la fuente jurídica que estamos examinando. ${ }^{83}$

Bien vale detenerse en otro testimonio de los últimos años de la centuria. Se trata de los Estatutos dados para la cátedra de Derecho Real de la Universidad de Caracas. Bajo la luz de las nuevas ideas y sin la traba de una tradición universitaria que impidiera la irrupción reformista, se establecían algunas disposiciones dignas de atención para la cuestión que venimos considerando. Al tratar del establecimiento material del aula, se disponía que en la misma debían tenerse "los volúmenes de las Leyes, Ordenanzas e Instrucciones y los Autores que sean precisos para la práctica...”. Según se observa, en pleno despliegue de una concepción legal del derecho, otra vez aparecían hermanados Leyes y Autores, aunque posiblemente se acentuase la exclusión del Derecho común. Así parecía cuando el Estatuto se ocupaba de la prueba de oposición a la cátedra. Los puntos debían escogerse de la legislación de Castilla e Indias y el opositor debía esforzarse en "combinar en su Disertación no sólo las leyes del Reino, Partidas, Fuero Real, Ordenamiento, Toro y Estilo; sino las de los Romanos, las del Derecho Canónico, Concilios,

82 "Plan para formar unas buenas instituciones de derecho español”, en Obras..., Madrid, 1844 , p. 362.

83 Víctor Tau Anzoátegui, “El 'Curso Hispánico Regio Legal' de Juan Antonio Llorente”, en RHD, núm. 12, 1984, pp. 455-456. 
decisiones de los Padres, Reales Ordenes, Cédulas y disposiciones municipales, explicando en lo que se hallen conformes, o no, y exornándola con aquellos de la historia que vengan al intento, y con las doctrinas de los Maestros Regnícolas que tienen séquito entre los Tribunales para que de sus luces se aprovechen los estudiantes, que deben en realidad ser todo el asunto y objeto de estas operaciones" ${ }^{\mathbf{8 4}}$

Se percibe en ambos ejemplos un crecimiento del criterio legalista que intentaba reducir - sobre todo en el ultimo - la doctrina de los autores a un papel más decorativo que decisivo. También se advierte una clara preferencia por los "maestros regnícolas" en contraposición a los doctores del Derecho común. Pero cualquiera sea esa limitación, la criticada doctrina parecía mantener cierto lugar, aun en mentes reformistas, cuando se trataba de la formación de los letrados en las aulas.

También la continuidad de los autores se manifestaba en el ejercicio profesional del abogado. Era, sin duda, una cuestión conflictiva que arrancaba ya, por lo menos, de aquel auto acordado castellano de 1713. Dicha cuestión presenta una doble faz. Se podía declamar contra la doctrina de los autores, pero a la hora de establecer la apreciación justa, no se podía prescindir de la misma. Así vemos al marqués de Bajamar, gobernador del Consejo de Indias a fines del XVIII y principios del XIX, despacharse contra el cúmulo de autores y obras en sus discursos de 1795 y 1801 y sostener la fidelidad a la ley "bien entendida y meditada, sin sujetarla al imperio de la opinión, ni a la inteligencia y sentido que hayan querido darla los glosadores y comentaristas". Era preciso - afirmaba - "descartar de los Tribunales el tropel de opiniones que tanto embarazan para el acierto de la administración de justicia". ${ }^{85}$ Pero en otro discurso intermedio - en 1799 - este alto magistrado decía que era obligación de los abogados que actuaban ante la Sala de Justicia del Consejo de Indias "exponer y hacer manifiesto el derecho que asista a sus clientes, fundándolo principalmente en las leyes del Reyno y en el dictamen de los autores de mejor nota, cuando el texto de la ley exija mayor

84 La copia utilizada en Real Academia de la Historia (Madrid), Colección Mata Linares, t. 120, fs. 159-178.

85 Marqués de Bajamar, Discurso exhortatorio..., 1795, pp. 24-25; y del mismo, Dos discursos exhortatorios, Madrid, 1802, p. 46. 
claridad y extensión al caso del día" ${ }^{\mathbf{8 6}}$ No tienen desperdicio estas palabras: desde tan alto estrado se proclamaba a la doctrina de los autores como instrumento necesario para aclarar la ley y aplicarla al caso suscitado. Ello ocurría cuando soplaban fuertes vientos legalistas y arreciaban las críticas contra las opiniones. No puede empero dejarse de anotar que las leyes del reino presidían en soledad el ordenamiento, aunque la inmediata compañía de los autores revelaba que su concurso era indispensable pese a las constantes diatribas que recibía, hasta del propio autor de la reflexión en otras ocasiones.

Esta misma dualidad puede apreciarse en Juan Francisco de Castro, conocido crítico del orden jurídico existente. Precisamente su censura hacia los autores era uno de los móviles de sus Discursos críticos, que hemos examinado anteriormente. Se quejaba Castro de que cada intérprete se hubiese constituido en "un pequeño legislador con autoridad semejante a la de la ley" y reconocía que "apenas se decide (algún caso) en la práctica sin el recurso a los doctores”. Apartarse de la doctrina común era apartarse de la ley misma y decidir contra ella era como decidir contra la ley. ${ }^{\mathbf{8 7}}$

El testimonio insospechado de Castro se confirma apenas nos acercamos a la praxis. Aunque las indagaciones realizadas hasta ahora no permiten extraer resultados definitivos, hay indicios vehementes que permiten señalar que la invocación de opiniones y autores en los escritos judiciales y en otros documentos de gobierno y justicia - alegada con fuerza vinculante - era moneda corriente, pese al auge de la crítica demoledora. Probablemente la intensidad de esas menciones y aun su mismo valor variase según se tratasen las diferentes materias jurídicas.

Se recoge la impresión generalizada de que abogados y jueces no concebían el Derecho sin el concurso de ese mundo de las opiniones y acudían a las mismas en su actividad cotidiana. En una demostración patente de lo que aquéllos buscaban por entonces en los libros, el editor de la ya famosa Curia Filipica en 1736 ponía énfasis en señalar que había enmendado citas y aña-

86 Marqués de Bajamar, Discurso exhortatorio..., 1799, pp. 56-58; Un estudio global y estimación de estos discursos en Daisy Rípodas Ardanaz, "Los 'Discursos exhortatorios' del Marqués de Bajamar" en Anuario Histórico Jurídico Ecuatoriano, Quito, 1980, t. VI, pp. 241-269.

87 Juan Francisco de Castro, Discursos críticos, cit., I, pp. 55-56. Peset destaca en este sentido la obra de Castro (“Derecho romano...”, cit., pp. 287-289). 
dido autores y doctrinas, favorables y contrarias a las del autor. ${ }^{\mathbf{8 8}}$ Varias décadas después, Reguera de Valdelomar - enrolado en la corriente crítica y partidario de un Derecho legal - reconocía que los tribunales han admitido y seguido esas opiniones, de tal modo que para actuar ante ellos no era suficiente el conocimiento de las leyes. ${ }^{\mathbf{8 9}}$

Es útil aprovechar los datos proporcionados por algunos estudiosos que, con diferente propósito y en diversas regiones, han indagado en escritos y expedientes judiciales, a fin de comprobar esa presencia de la doctrina de los autores en la instancia de aplicación del derecho. Veamos. La profesora María Luz Alonso, después de examinar una importante colección de 75 alegaciones del jurista novohispano Juan Antonio Torquemada, escritas entre 1723 y 1727 en causas penales defendidas ante la Audiencia de Nueva España, resalta el constante manejo y cita de la doctrina de los autores y del Derecho común para fundar sus argumentos, a causa del amplio vacío que dejaba la legislación penal. ${ }^{90}$ Es singular - pero, sin duda, elocuente - el cómputo de citas practicado por el profesor Peset Reig en una alegación de 1740 en Valencia, relativa a una causa sobre contrabando de seda: 10 citas de clásicos latinos, 9 textos jurídicos españoles, 38 de Códigos y Digesto y ¡nada menos que 167 doctrinarias! ${ }^{91}$ Otro estudioso, Javier González Echenique, sostiene que en los informes en derecho presentados ante los tribunales seculares chilenos durante esta centuria se comprueba una abundantísima cita de autores - junto a las leyes reales y aun las romanas -, al punto que en uno de ellos, de 16 fojas de extensión, ha registrado más de sesenta autores distintos. ${ }^{92}$ No precisa, lamentablemente, si se aprecian diferencias en la intensidad de estas invocaciones, según fuese el tipo de causa judicial. A su vez, Roberto I. Peña, buen conocedor de los expedientes matrimoniales

88 J. M. Domínguez Vicente, Ilustración y continuación de la Curia Filipica, t. I, 1736, p. s/n.

89 Resumen de la historia cronológica del derecho y leyes de España, Madrid, 1798, pp.91-94.

90 "Un jurista indiano: Juan Antonio Torquemada", en Justicia, Sociedad y Economía Española (siglos XVI, XVII y XVIII), Valladolid, 1983, pp. 205 yss. Sobre la doctrina de los autores como fuente del derecho penal, se ocupan en general Tomás y Valiente, El Derecho penal..., cit., pp. 85 y ss. y Abelardo Levaggi, Historia del derecho penal argentino, Buenos Aires, 1978, pp. 20-23.

91 Peset, "Derecho romano y derecho real...”, cit., p. 297. Lo recuerda Petrt, "Derecho común y Derecho castellano...", cit., p. 186.

92 Javier González Echenique, Los estudios jurídicos y la abogacía en el Reino de Chile, Santiago de Chile, 1954, pp. 197-199. 
existentes en los tribunales eclesiásticos de Córdoba de los siglos XVII y XVIII, además de dar testimonio sobre la constante invocación de los canonistas más renombrados - como Reiffenstuel -, detecta la presencia viva de esa doctrina en la interpretación del texto legal, en la formación de la costumbre, en la conveniente apreciación del caso, en el estilo judicial, en los modos de abogar y sentenciar. ${ }^{93}$

Los estudios de Javier Barrientos Grandón, sobre procesos judiciales en Nueva España permiten ofrecer interesantes conclusiones. Se observa así en dicha praxis - sobre todo verificada en el siglo XVIII - que letrados y jueces argumentaban en sus actuaciones no solo con las leyes sino también con las opiniones de los autores. El caudal doctrinario se hacía ostensible en los alegatos, dictámenes de asesores, vistas de los fiscales, votos consultivos y sentencias de audiencias, prolongándose hasta avanzado el siglo XIX. Se destacan el alcance y frecuencia de estas citas de autores en los procesos eclesiásticos. En el orden civil, en el siglo XVIII se percibe una tendencia creciente a la invocación de autores regnícolas. ${ }^{94}$

En cambio, María Isabel Seoane, al examinar los escritos de los procuradores de la ciudad de Buenos Aires ante el Cabildo, encuentra que la doctrina de los autores era citada de modo mucho menos frecuente en relación a las leyes y costumbres. ${ }^{95}$ Esto mismo lo he observado en general en las actas de los cabildos de Buenos Aires, Montevideo, Luján y Santiago del Estero. En la documentación capitular, Castillo de Bobadilla y Solórzano están entre los autores más mencionados.

Un testimonio singular permite constatar cómo preparaba sus sentencias un alto magistrado indiano a fines del siglo XVIII. Mariluz Urquijo, en un inteligente buceo en los papeles del Regente de la Audiencia de Buenos Aires, don Benito de la Mata Linares, ha encontrado y valorizado unas anotaciones de este magistrado vinculadas a la resolución de los pleitos que tenía a su consideración. En dichos apuntes, no sólo los autores aparecen

93 Peña, "Fuentes del Derecho Indiano...," cit., p. 111.

94 Javier Barrientos Grandón, La cultura jurídica en la Nueva España, Universidad Nacional Autónoma de México, 1993, pp. 240 y ss.

95 María Isabel Seoane, “El procurador general de la ciudad”, en $R H D$, núm. 12, p. 250; y de la misma autora, "Las fuentes jurídicas de los memoriales de los síndicos procuradores de Buenos Aires", en Revista Chilena de la Historia del Derecho, núm. 11, Santiago, 1985, pp. 373-375. 
junto a las leyes en constante invocación sino incluso a veces las leyes eran conocidas y citadas a través de dichos autores. ${ }^{96}$ Entre éstos hay una clara preeminencia de los hispanos, lo que confirmaría una tendencia de abandono de los doctores del Derecho común, aunque no de la doctrina como fuente directa. El interés de este dato crece cuando consideramos que Mata Linares era un típico juez de la Ilustración y que al cesar como Regente en Buenos Aires pasó a desempeñarse como ministro en el Consejo de Indias. Análoga disposición para apoyarse en la doctrina puede apreciarse en los dictámenes de los fiscales de la misma Audiencia bonaerense de esa época. ${ }^{97}$

\section{Hacia una creación jurídica sin opiniones ni autores}

Cabe preguntarse hasta cuándo la doctrina de los autores subsistió con el carácter que hemos apuntado a lo largo de estas páginas. El movimiento crítico estaba destinado, aunque a largo plazo, a producir efectos demoledores. Entre tanto, iba madurando la reforma del Derecho, viejo anhelo según vimos, cuyos primeros frutos se vislumbraron ya a fines del siglo XVIII, al iniciarse el proceso de la codificación. Este fue el momento en que - al menos teóricamente - la doctrina debía dejar de ser fuente directa de nuestro derecho positivo. Y así fue. Pero la codificación no abarcó todas las áreas ni se produjo en todas partes a un mismo tiempo. Valga recordar que un siglo separa el modelo civil francés del alemán. En el mundo hispano el proceso se extendió a lo largo del siglo XIX, con particular despliegue en la segunda mitad. ${ }^{98}$

Hay indicios que permiten suponer que aún durante varias décadas del ochocientos, la doctrina de los autores mantuvo algún lugar destacado en el horizonte del jurista en cuanto a la interpretación y aplicación del Derecho. El dato que nos ofrece Coing, al expresar que dicha doctrina tuvo un lugar eminente entre los legistas de Alemania del siglo XIX, comparable a los del

96 José M. Mariluz Urquijo, "La acción de sentenciar a través de los apuntes de Benito de la Mata Linares”, en RHD, núm. 4, 1976, pp. 141 y ss.

97 Véase Abelardo Levaggi, "El concepto del Derecho según los fiscales de la segunda Audiencia de Buenos Aires. 1784-1810", en Revista Chilena de Historia del Derecho, núm. 11, Santiago, 1985, pp. 257-259.

98 Víctor Tau Anzoátegui, La codificación en la Argentina. 1810-1870. Mentalidad social e Ideas jurídicas. Segunda edición revisada, Buenos Aires, 2008; Alejandro Guzmán Brito, La codificación civil en Iberoamérica. Siglos XIX-XX, Santiago, Chile, 2000. 
medievo italiano, ${ }^{99}$ tiene para nosotros valor indicativo, en cuanto refleja la situación en un país europeo sin código. La historiadora mexicana María del Refugio González apunta que ha visto citada dicha doctrina en la mayor parte de los textos y alegatos jurídicos, e incluso en las sentencias en ese país hasta $1871{ }^{100}$ En el mismo sentido puede añadirse que en los reglamentos de administración de justicia de algunas provincias argentinas, a mediados de la centuria, se preveía que el juez pudiese acudir a la doctrina de los autores a falta de leyes, costumbres u otras fuentes. Dentro de estos indicios que registramos, es interesante agregar que el profesor Alejandro Guzmán detecta esa doctrina en el pensamiento y en la obra codificadora de Andrés Bello, autor del Código civil chileno, uno de los cuerpos más significativos e influyentes en Hispanoamérica. ${ }^{101}$

Este aspecto debiera ser objeto de una indagación especial, ajena a mi cometido presente. Está comprendido dentro del interesante proceso de transformación del Derecho indiano en los Derechos nacionales de los Estados hispanoamericanos, aun con pocas investigaciones fundamentales. De cualquier modo, he querido avanzar en el tiempo más allá de nuestro límite para añadir un nuevo elemento de comprobación a lo que hemos desenvuelto en este estudio.

\section{Los libros con auctoritas, fijadores de la jurisprudencia castellano-indiana}

En páginas anteriores he destacado la fuerza vinculante alcanzada por las opiniones y por los libros con auctoritas. Cabe ahora hacer una referencia concreta a algunas de esas obras sobresalientes dentro del Derecho castellano-indiano. Dichas obras fijadoras eran indispensables dentro de un ordenamiento donde la doctrina de los autores gozaba de considerable aprecio. No es fácil establecer rangos o categorías en esta cuestión. Es cierto que las obras de conjunto, es decir aquellas que abarcaban una parte importante del ordenamiento aparecían con más ventaja para alcanzar una alta posición, pero también había otras sobre materias concretas que adquirieron igualmente notoriedad y autoridad entre los juristas.

99 CoIng, “Trois formes...”, cit., p. 538.

100 María del Refugio González, El derecho civil en México..., cit., p. 127.

101 Guzmán Brito, "La decisión de controversias jurisprudenciales..., cit., en nota 51. 
Me limito ahora a mencionar cuatro obras de tipo general, de naturaleza distinta, que alcanzaron en la esfera indiana una prolongada y eminente presencia: las glosas de Gregorio López a las Partidas (1555), la Política para corregidores y señores de vasallos de Gerónimo Castillo de Bobadilla (1597), la Curia Philipica de Juan Hevia Bolaños (1603) y la Política Indiana de Juan de Solórzano Pereira (1647). ${ }^{\mathbf{1 0 2}}$ Obras jurídicas enmarcadas en el clima creador del "siglo de oro" español, cada una tuvo su particular y rica trayectoria durante varias centurias. De más nítido origen castellano las dos primeras, sin embargo alcanzaron una vigencia americana tan intensa que bien podría hablarse de la "vida indiana" de cada una. Todas tuvieron vasta circulación y sucesivas ediciones en los siglos XVII, XVIII - y aun XIX -, ya en tiempos en que la doctrina de los autores, según vimos, era censurada sin contemplaciones y aparecía en franca declinación. Algunas obras escaparon airosas a los acerados juicios críticos. Cuando Juan Pablo Forner se ensañaba con los escritores juristas en sus Exequias, fustigándolos desde diversos ángulos en tono satírico, sólo se salvaban "las dos Políticas de los magistrados Bobadilla y Solórzano, únicas obras de jurisprudencia que han merecido entrar en la biblioteca del Parnaso". ${ }^{103}$

Las obras que destacamos eran epigonales y procedían a fijar la jurisprudencia. Su contenido era amplio, pues hacían acopio de muy diversas fuentes y recibían el apoyo de leyes y costumbres, prácticas judiciales y doctrinas. Esto mismo, más allá de la autoridad que podían alcanzar, determinaba que el jurista las utilizara a la par que los cuerpos legales. Incluso a veces eran preferidas a éstos por reunir una mayor diversidad y número de preceptos jurídicos de todo tipo. No hay que olvidar que el jurista casuista necesitaba apoyos jurídicos para dar solución a la situación concreta planteada y con más frecuencia los encontraba en este tipo de obras que en los mismos cuerpos legales. Este es el sentido que, en mi opinión, despunta en una expresión que leemos en las actas capitulares bonaerenses en 1754. Fue entonces cuando un regidor ante la discusión suscitada acerca de si el paseo

102 Ricardo Zorraquín Becú, al referirse a las fuentes del derecho indiano hasta 1680, afirma que la "doctrina tuvo mucha gravitación en las decisiones gubernativas y judiciales", acudiéndose para resolver los casos a los libros de Castillo de Bobadilla, Hevia Bolaños y desde mediados del siglo XVIII, Solórzano ("Las fuentes del derecho argentino..., cit., p. 319).

103 Exequias de la lengua española, edición Austral, Buenos Aires, 1952, p. 116. También p. 104. 
del real estandarte se había de hacer a pie, en vez de a caballo como era lo habitual, propuso que "se busque la ley, en la de Indias, Curia Philipica o Bobadilla o donde se hallare...” ${ }^{104}$ Lo que ese regidor estaba buscando era el respaldo jurídico para la decisión y no necesariamente una ley real, sino una norma de cualquier tipo que diera solución a la cuestión planteada.

Otro testimonio de los mismos años, aunque de diferente nivel, corrobora esta interpretación. Se trata del juicio de Mora y Jaraba, al exigir que los oficiales de las Secretarías del Despacho Universal fuesen letrados. Sostenía dicho escritor que quien no hubiese abierto la Recopilación, ni pudiese entender - aunque los leyese - los libros de Solórzano y Pinelo, ni pueda tampoco penetrar el singular derecho canónico indiano, no estaba en condiciones de entender una consulta o cualquier expediente relativo al gobierno indiano. ${ }^{105}$ Es sugestivo que también aquí aparecieran hermanados, como requisito mínimo de aptitud, el conocimiento de leyes y autores, sin los cuales era imposible penetrar en los negocios públicos.

Las obras epigonales constituían un selecto grupo que sobresalía sobre el resto de la literatura jurídica. Se distinguían por la autoridad que les era reconocida. Diversos factores influían en ello: la personalidad del autor, la calidad intrínseca del libro, la oportuna aparición como obra fijadora, etc. A su vez, para su prolongada vigencia en el tiempo contribuían la ausencia de nuevas obras fijadoras, las reediciones anotadas y el mismo crecimiento de la aureola de prestigio que las rodeaba. Sin embargo, el meollo estaba en el acierto con que llenaban la función fijadora de la jurisprudencia que la sociedad reclamaba y con que recogían lo que se estimaba propiamente por derecho vigente. Es lo que en 1736 expresaba el reeditor y anotador de la Curia Philipica en estas sencillas palabras: "es una obra apreciada en toda España y mucho más en las Indias, por la facilidad con que toca, y resuelve las cuestiones más difíciles de Derecho y la puntualidad de la más segura sentencia". ${ }^{106}$

104 Acuerdos del extinguido Cabildo de Buenos Aires, serie III, t. I, Buenos Aires, 1926, p. 466.

105 Pablo de Mora y Jaraba, La ciencia vindicada contra los plumistas y definición de las Secretarías del Despacho Universal (1747), Mss. En Miscelánea de Ayala, t. XIV, f. 312 (Biblioteca de Palacio, Madrid, núm. 2828). Los secretarios de Estado y del Despacho, t. IV, $2^{\text {a }}$ edición, Madrid, 1976, pp. 1167-1186.

106 Domínguez Vicente, Ilustración..., cit., dedicatoria. Sobre el sentido de obras epigonales, véase Guzmán Brito, La fijación..., cit., pp. 33-34. 
Quisiera profundizar esta cuestión en cabeza de la obra más específicamente indiana de las citadas en este parágrafo. Me refiero, como es natural, a la Política Indiana, de Solórzano, cuya penetrante presencia en la creación y aplicación del derecho es bien conocida. Algunos datos, provenientes del siglo XVIII, servirán para apoyar lo que acabamos de exponer.

Escribía Varela de Ureta en 1733 que el Consejo de Indias rendía a Solórzano "una veneración tan ciegamente profunda, que libra en estas obras, sin arbitrio sus aciertos en la gobernación universal y particular de aquellos Reynos en tanto grado, que es más fácil separarse de la disposición de una ley, que de la autoridad de este Escritor. ${ }^{\mathbf{1 0 7}}$ En otro pasaje agregaba que los ministros del Consejo, ayunos en materias indianas, se amparaban sólo en la Recopilación y en la mencionada Política.

Acudamos a otros testimonios corroborantes. Cuando en 1750 la Universidad de Lima en carta al rey citaba a Solórzano con respecto a la admisión de mestizos, zambos, mulatos y cuarterones en las matrículas y grados, puntualizaba que su autoridad "en cuanto al gobierno de las Indias está reputada por punto menos que las leyes en lo no decidido por ellas...." ${ }^{108}$ Diez años después, era el propio Consejo quien confirmaba esta difundida impresión. En la resolución de una duda planteada por el arzobispo de Lima al rey se contenía esta singular respuesta: "procedereis arregladamente en este y otros semejantes casos que ocurran, conformandoos con la opinión de Dn. Juan de Solórzano en el libro quarto de su Política Indiana, capítulo diez y siete, número cuarenta y tres". 109

La valoración de estos documentos debe hacerse teniendo en cuenta que 1750 y 1760 son fechas tardías para nuestro tema, en las cuales se aprecia ya el avance resuelto de la supremacía legal. El segundo testimonio ofrece un buen ejemplo de adhesión legislativa a la opinión de Solórzano, propiciada por el Fiscal y plasmada por el Consejo. Curiosamente no se adoptaba la doctrina, incorporando su contenido a la disposición legal, sino se mantenía la individualidad de aquélla, con indicación precisa de la cita. Además, la solución no quedaba restringida al caso consultado sino que se extendía a

107 Alonso Varela de Ureta, Discurso político práctico, que propone cuál debe ser la formación del Consejo Real y Supremo de las Indias, fechado en Cádiz en 1733, pp. 34-35.

108 Carta de 23 de diciembre de 1750 (AGI, Lima, 417).

109 Se trata del borrador de una real cédula de 12 de febrero de 1760, que he consultado en AGI, Lima, 807. 
otros semejantes que ocurriesen. Algo más se puede agregar, esta vez en cuanto al fondo del asunto. La duda planteada era acerca de si los regulares podían ser excomulgados por el Diocesano, en los casos que estaban sujetos a la jurisdicción inquisitorial. La cuestión aparecía muy controvertida, aunque la posición de Solórzano era francamente afirmativa. Se trataba de una opinión que, en su argumentación, encontraba apoyos legales, doctrinarios y de decisiones judiciales pero tenía también un sello propio. ${ }^{\mathbf{1 1 0}}$ Estamos en presencia de un sustancioso ejemplo de elaboración netamente jurisprudencial.

Volvamos al testimonio de Varela de Ureta. Las palabras que he utilizado de este escritor tienen valor propio para apoyar la presencia de las obras de Solórzano en el Consejo de Indias. Pero conviene advertir que las mismas se encontraban dentro de un texto en el cual se revelaba que los ministros del Consejo carecían de experiencia y conocimiento directo de las Indias. Esto le llevaba a afirmar en otro pasaje: "Por lo mismo que las obras de este gran Ministro son acreedoras a todos los aplausos, que les da el orbe literario, y ellas han sido ciertamente muy convenientes para informar, e instruir a los Ministros, que no han estado, ni servido en las Audiencias y Chancillerías de Indias; debemos confesar que conviene crear otros Solorzanos, que nos den nuevas noticias de todos los parages, pues sólo nos suministra las de Lima, en que siempre se mantuvo...", siendo preciso tener en cuenta la variación de los lugares y también de los tiempos y de igual modo la existencia de diferente opinión o criterio. ${ }^{\mathbf{1 1 1}}$ Estas nuevas palabras ofrecen más de un perfil aprovechable. Desde luego, sirven para afirmar nuevamente, si ello fuese todavía necesario, esa autoridad que coronaba la obra de Solórzano hacia el primer siglo de su aparición. Era casi un reinado absoluto. Pero me interesa ahora destacar aquella parte en la que Varela advertía limitaciones en la obra solorciana para que continuase en vigencia, en razón del lugar y el tiempo de donde el autor extrajo sus conocimientos y experiencias. Así también advertía la falta de otros criterios u opiniones que permitiesen completar o contrastar los juicios del gran jurista. De ahí el deseo expresado de que existieran "otros Solorzanos". Esto nos lleva a observar en el Derecho indiano una

110 Para esto véase los números 44 y siguientes de dicha cita, en donde inclusive el anotador Valenzuela hizo diversos agregados a partir de la edición de 1736.

111 Varela de Ureta, Discurso..., cit., pp. 35-36. 
situación probablemente distinta a la que generalmente se denunciaba en el ámbito del Derecho común: la abundancia y contraposición de opiniones. Varela de Ureta se quejaba curiosamente de lo contrario: el reinado exclusivo de un autor y la falta de otras opiniones. ¿Es que en Indias no se daban algunos de esos factores que venían produciendo la declinación y desgaste del "derecho de juristas" en el Viejo Mundo? ¿Esas turbaciones tenían otros grados o matices? Naturalmente queda pendiente también un último interrogante: ¿El clima ideológico del siglo XVIII acaso podía favorecer el surgimiento de émulos de Solórzano?

\section{Consideraciones finales}

En vez de cerrar esta exposición con unas conclusiones, cabe declarar abierto el tema a nuevos interrogantes, indagaciones e interpretaciones dentro del amplio y atractivo marco que nos ofrece una Historia del Derecho liberada de las ataduras del legalismo y dispuesta a verificar distintas situaciones de la jurisprudencia a través del tiempo.

Me he limitado a una presentación general del tema. En un primer paso, era necesario ubicar a la doctrina de los autores más allá de los textos legales que la encauzaron, limitaron o desconocieron. Después cabía verificar la invocación y utilización de las opiniones y de las obras jurisprudenciales en la vida jurídica. Esto nos ha llevado a considerar la función directiva alcanzada por los autores en la creación del derecho castellano-indiano de los siglos XVI a XVIII, sin ceñirla a una determinada fuente formal. Sólo así se explica la vigorosa postura crítica que hemos visto consolidada en el siglo XVIII en torno a la denominada "ideología antijurisprudencial".

Quedan aspectos importantes por explorar. Hay vehementes indicios de que la doctrina de los autores no tuvo presencia y fuerza por igual en todas las ramas y materias jurídicas. ¿Qué factores incidieron en ello y cómo se dio esa distinción? De igual modo, poco sabemos sobre la elaboración de la obra jurisprudencial, su estructura y acerca de la manera en que la utilizaban los juristas. ${ }^{112}$

112 En este sentido resultan de interés las páginas que Bravo Lira dedica a la cuestión en su trabajo "La literatura jurídica..., cit., pp. 253-262. 
Esto nos lleva, en fin, a plantear - una vez más - unos interrogantes decisivos para la tarea del historiador: ¿el derecho aplicable en Castilla e Indias era estrictamente el expresado en los distintos órdenes de prelación legal? $\mathrm{O}$, en cambio ¿era un conjunto normativo más amplio, complejo y diverso, en el cual convergían leyes, costumbres, opiniones, autores, prácticas judiciales, ejemplares y otros precedentes, etc.? Aunque ya los antiguos trabajos orientadores de Levene y Altamira daban pie para responder afirmativamente la segunda pregunta, sin embargo hasta ahora ha continuado predominando en nuestra historiografía una visión legalista - expresada en enfoques generales y en la misma labor monográfica - que lleva a suponer una contestación positiva a la primera pregunta y a ignorar la segunda.

La comprensión histórica del Derecho indiano y por consiguiente la orientación de las tareas de investigación en su ámbito, dependen, en buena medida, de la respuesta que demos a aquellos interrogantes. Mis indagaciones sobre las distintas fuentes del derecho me han llevado paulatinamente $-\mathrm{y}$ cada vez con mayor firmeza - a responder afirmativamente aquella segunda pregunta. Esto no significa, a mi juicio, que la ley deje de ocupar el más destacado lugar entre dichas fuentes y que, por tanto, el ordenamiento indiano pueda perder su calificación de "derecho legal". Pero sí estimo que es preciso recortar el sentido de esta expresión, matizándola e incluso diferenciar el sentido con que empleamos hoy, la noción de "legalidad" con relación a la utilización dada en aquella época. De una parte, está demostrada la inserción del fenómeno consuetudinario, que era admitido e invocado en la misma ley, acogido en la obra jurisprudencial e influyente en la praxis. En esta contribución, a su vez, hemos comprobado la constante referencia a Leyes y Autores en muchos documentos para establecer el horizonte intelectual del jurista. Probablemente, otros modos de creación del derecho esperan que sean explorados... De tal modo, si bien se observa un "derecho legal" en franco avance ¿podría desconocerse la presencia de los otros elementos? Y en particular, ¿no es pertinente apuntar la persistencia de un "derecho de juristas" - o al menos de una concepción jurisprudencial del derecho -, aunque ya en inexorable proceso de declinación? 


\section{Entre leyes, glosas y comentos. El episodio de la Recopilación de Indias*}

Sumario: 1. Planteamiento del tema - 2. Leyes y autores, dos modos principales de establecer el Derecho en el siglo XVII - 3. Las leyes entretejidas con los autores: ¿una recopilación con glosas? - 4. Las obras jurisprudenciales, una historia paralela - 5. Las leyes como "verdadera jurisprudencia" 6. ¿Una puja silenciosa? - 7. Impulso al modelo legalista - 8. Apuntes finales

\section{Planteamiento del tema}

Aún tengo viva en la retina la calurosa tarde del 16 de julio de 1992, cuando visité a don Alfonso García-Gallo en su casa madrileña. Fue la última vez que lo vi. El día anterior había recibido el doctorado honoris causa de la Universidad Complutense, rodeado de discípulos y amigos en una solemne ceremonia en el Paraninfo de la calle San Bernardo. El mal estado de su vista le impidió leer el discurso de agradecimiento. Empero conservaba plenamente la lucidez y ánimo. Aquella tarde de despedida esbozó la idea que le preocupaba en torno a un viejo tema de investigación que, ciertamente, no había abandonado en sus largos años de labor sobre el Derecho Indiano: el proceso de elaboración de la Recopilación de 1680 y, sobre todo, el rol desempeñado por sus más conspicuos protagonistas, Antonio de León Pinelo y Juan de Solórzano Pereira.

Este recuerdo ha sido decisivo para que, a la hora de escoger alguna ofrenda en homenaje al maestro, haya precisamente elegido una pequeña contribución en torno a este tema que continuó apasionándole hasta sus últimos días. Ello me ha llevado a releer sus escritos y, sobre todo, a efectuar una lectura crítica de escogidos textos a la luz de nuevas reflexiones que permitan ampliar el enfoque interpretativo. Algo que, por cierto, GarcíaGallo hizo y enseñó a hacer en su larga vida de estudio.

* Publicado en Homenaje al Profesor Alfonso García-Gallo. Editorial Complutense S. A., Madrid, 1996, t. III, vol. 1, pp. 267-283. 
Sirvan estas motivaciones afectivas para explicar que lo que voy a exponer en estas páginas no es un trabajo acabado, sino sólo el hilo de una trama que está en el telar. Esto quiere decir que el asunto forma parte central de mi labor de investigación. Pero también significa que no puede ser apreciado de modo aislado y mucho menos si se hace desde un ángulo visual restringido.

Como es sabido, el largo proceso de preparación de la Recopilación de Indias está lleno de oscuridades y ambigüedades, de silencios y vacíos, de disposiciones y actitudes desconcertantes, todos los cuales han alimentado hipótesis e interpretaciones. Especialmente controvertido es el período que empieza con la intervención del consejero Rodrigo de Aguiar y Acuña en la segunda década del siglo XVII y se extiende hasta la sanción de 1680. Calificados estudiosos, de diversas generaciones se han ocupado de ello. Los nombres de Rafael Altamira, ${ }^{1}$ José Torre Revello, ${ }^{2}$ Juan Manzano, ${ }^{3}$ Alfonso García-Gallo, ${ }^{4}$ Ismael Sánchez-Bella ${ }^{5}$ y Concepción García-Gallo ${ }^{6}$ destacan entre los demás por el aporte que, en distintas épocas, efectuaron, ya con documentos, ya mediante reflexiones críticas o interpretaciones, muchas de ellas encontradas. Con tales esfuerzos, puede estimarse que la principal documentación referente al tema está al alcance de los estudiosos, sobre todo después del hallazgo de Sánchez-Bella.

Afirmado, ahora de forma definitiva, el papel fundamental que desempeñó León Pinelo como artífice de la Recopilación - que confirma la antigua tesis de Manzano -, queda sin explicación convincente el significativo atraso

1 Rafael Altamira, "La intervención de don Juan de Solórzano en la Recopilación de Indias", en Revista de Ciencias Jurídicas y Sociales, Facultad de Derecho, Universidad de Madrid, año III (1920), pp. 50-59; y del mismo, "La extraña historia de la Recopilación de Antonio de León Pinelo", en Boletín da Facultade de Direito da Universidade de Coimbra, n 25 (1949), pp. 99-118 y 280-304; n 26 (1950), pp. 1-32; y no 27 (1951), pp. 1-38.

2 José Torre Revello, Noticias históricas sobre la Recopilación de Indias (Buenos Aires, 1929); y del mismo autor, Ensayo biográfico sobre Juan de Solórzano Pereira (Buenos Aires, 1929); ambos con valioso apéndice documental.

3 Juan Manzano Manzano, Historia de las Recopilaciones de Indias, vol. II (Madrid, 1956).

4 Alfonso García-Gallo, "La Nueva Recopilación de las Leyes de Indias de Solórzano Pereira”, en Anuario de Historia del Derecho Español, núm. 21 (Madrid, 1951), pp. 529-606.

5 Ismael Sánchez-Bella, "Hallazgo de la Recopilación de las Indias de León Pinelo", en Jabrbuch für Geschichte von Staat, Wirtschaft und Gesellschaft Lateinamerikas, núm. 24 (Köln-Wien, 1987), pp. 135-177.

6 Concepción García-Gallo, "La legislación indiana de 1636 a 1680 y la Recopilación de 1680”, en Anuario de Historia del Derecho Español, núm. 49 (Madrid, 1979), pp. 99-119. 
que sufrió la impresión de ese cuerpo legal entre el proyecto de 1636 preparado por León Pinelo y revisado por Solórzano - y la sanción, claro que con variantes, de 1680. Esta "larga espera" ha dado lugar a diversas conjeturas por parte de dichos historiadores. La falta de dinero - o su escamoteo o desviación, cuando lo hubo -; los recelos personales o profesionales; la necesidad de practicar nuevas revisiones del texto; algún propósito deliberado de dificultar la impresión; cierta desgana o indiferencia del Consejo de Indias, han sido causas aducidas para explicar este atraso de casi medio siglo. Sánchez Bella ha vuelto a hacer hincapié en que esta tardanza se debió a "razones fundamentalmente económicas". En fin, como dice Antonio Muro, parecía que "un maléfico hado" demoraba la aprobación o impresión del cuerpo legal. ${ }^{\mathbf{8}}$

El nuevo punto de vista que aproximo a esta discusión no pretende desechar enteramente las explicaciones anteriores ni, por supuesto, erigirse en la causa única del aludido retardo. Tiende, eso sí, a buscar motivaciones de mayor hondura y no simplemente periféricas, como las intentadas hasta ahora. Cabe así preguntarse si en esta "larga espera" no incidió también un elemento vertebral en la sensibilidad jurídica de la época, cual era la presencia de la jurisprudencia de los autores, de cuyo papel directivo en el Derecho castellano-indiano he tenido oportunidad de ocuparme. ${ }^{9}$ A mi juicio, la

7 Sánchez-Bella, “Hallazgo de la Recopilación...”, cit., p. 169. Frente a esta afirmación, Zorraquín Becú ha sostenido que hubo algo más que falta de recursos y que mediaron "otras razones no conocidas o no confesadas que explicarían esa increíble desidia del Consejo de Indias". Sus conjeturas apuntan a suponer una cierta resistencia o mezquindad entre los consejeros a reconocer y promover la obra de León Pinelo, pero aún así no se explica tal actitud cuando - dice - "no existía otra tarea más importante, más necesaria y más urgente para el Consejo”. (Ricardo ZorraQuín Becú, “El hallazgo de la Recopilación de León Pinelo" en Revista de Historia del Derecho, $\mathrm{n}^{\circ} 16$ (Buenos Aires, 1988), p. 550).

8 Antonio Muro Orejón, "La Recopilación de Indias de 1680", en Justicia, Sociedad y Economía en la América Española (siglos XVI, XVII y XVIII), (Valladolid, 1983), p. 57. A las razones conocidas me permito recordar un juicio estampado por Solórzano en un dictamen de 1653, en el cual instaba al Consejo a observar cierta prudencia en las nuevas órdenes que se expedían, tomando siempre conocimiento de las antiguas, pues al proveerse unas contrarias a otras no había ley ni ordenanza fija, y agregaba que "esta es una de las razones por donde se ha retardado la impresión de la Recopilación de las Leyes de Indias, después de haberla trabajado tanto" (Víctor Tau Anzoátegui, Casuismo y Sistema. Indagación histórica sobre el espíritu del Derecho Indiano, (Buenos Aires, 1992), p. 397).

9 Para un desarrollo general de esta cuestión remito a mi trabajo "La doctrina de los autores como fuente del Derecho castellano-indiano", en Revista de Historia del Derecho, $\mathrm{n}^{\mathrm{o}} 17$ (Buenos Aires, 1989), pp. 351-408. Ahora también en el presente volumen (V). 
respuesta afirmativa puede obtenerse de la percepción del sentir colectivo, corroborada con testimonios concretos extraídos de la documentación conocida.

Para entender este planteamiento es necesario apartarse del paradigma legalista y sistemático que ha dominado - y que permanece fuertemente arraigado - en nuestra historiografía jurídica. Según dicho paradigma, el derecho se expresa solo por vía de la ley dada por la autoridad estatal y constituye un sistema abarcador de todas las relaciones sociales. Se trata de una concepción prevalente en los siglos XIX y XX que lleva al historiadorjurista a observar el pasado anterior a esa época, bajo una lente jurídica monocolor, sin atender a los modos plurales de su creación o establecimiento y sin percatarse de la textura casuista que domina la mente de los juristas. ${ }^{10}$ En suma, es preciso colocarnos, en otro lugar de observación para encontrar las explicaciones que nos resultan insastisfactorias y hasta desconcertantes si nos quedamos aferrados a aquel paradigma.

Tan influyente es este paradigma que ha podido atrapar en sus redes a historiadores-juristas, que gozaban de un amplio horizonte intelectual. Es el caso de Rafael Altamira, quien, a través de sus trabajos, mostró un Derecho indiano no recluido en el fenómeno legal. Sin embargo en el ensayo dedicado a estudiar el tema que nos ocupa, cuando enuncia las posibles causas de la demora en imprimirse la Recopilación y, más aún, al interrogarse si "no habría algún otro motivo, independientemente de esa dificultad económica, ${ }^{11}$ no insinúa ninguna hipótesis que vincule la cuestión con las concepciones jurídicas entonces existentes.

Si el cambio del puesto de observación que propongo puede ser beneficioso para comprender mejor esta "larga espera", con todo, mi objetivo no queda reducido a arrojar luz sobre una cuestión episódica que, por interesante, no deja de tener valor relativo, atinente a dilucidar un punto erudito. Creo que esta indagación puede suscitar provechosas consecuencias sobre la

10 Sobre esto, véase Tau Anzoátegui, Casuismo y Sistema..., cit.

11 Altamira, "La extraña historia..., cit., no 26, pp. 27-28 y n ${ }^{\circ} 27$, p. 7 . Solo en la primera ocasión hace una referencia a la posibilidad de que hubiesen aparecido "nuevas exigencias o escrúpulos de parte del rey, o de consejeros íntimos suyos, respecto de las condiciones que deberían llenar el texto y la falta de ellas en el preparado en el consejo y, por supuesto, en el de Pinelo, si aún existía por separado”. 
aplicación misma de la Recopilación, ya que nos revela aspectos nucleares de la mentalidad de los juristas que la ejecutaban.

No es impertinente que exprese por último, y sobre todo, mi interés en mostrar a través de este episodio, la necesidad de buscar nuevas vías de comprensión y explicación del pasado jurídico, que vayan más allá del paradigma legalista que frecuentemente ha estrechado el horizonte intelectual de los historiadores-juristas, cercenando la crítica creativa en más de una cuestión historiográfica.

\section{Leyes y autores, dos modos principales de establecer el Derecho en el siglo XVII}

El Derecho del siglo XVII estaba dominado por la creencia de que el mismo se establecía por diversos modos y autoridades, si bien en ciertas áreas y materias empezaba a destacarse el "poderío real" para dictar las normas. En tanto la costumbre conservaba una respetable presencia, la jurisprudencia de los autores mantenía considerable fuerza jurídica, lo cual se ponía en evidencia tanto en las aulas como en los tribunales. Mientras en algunas materias relucía con fulgor propio, en otras lo compartía con diversos modos de creación jurídica, especialmente la ley. Ambos, leyes y autores, aparecían como principales. Con frecuencia se presentaban unidos. Así los textos legales dados por el rey eran acompañados de glosas o incorporados a los comentos. Los autores explicaban o interpretaban - a veces apartándose notoriamente del texto - apoyados en esa rancia jurisprudencia de civilistas y canonistas de los Derechos común e hispano, que gozaba de auctoritas. Operaban, pues, como controles del poder normativo de los reyes, contrastando su precepto con lo que el Derecho enseñaba.

Pero también se podía descubrir una rivalidad entre ambos modos creativos, que llevaría centurias después al triunfo absoluto de la ley. Ya por entonces se abatía sobre los autores una fuerte crítica por parte de letrados y profanos, fundada sobre todo en la incertidumbre y confusión que creaban el cúmulo de opiniones. Las leyes, en cambio, permitían respuestas ciertas y rápidas a las nuevas situaciones planteadas y, esto particularmente, se hacía patente en sectores del ordenamiento indiano.

A medida que se produjo el crecimiento del poder real con la pretensión de reducir las limitaciones a su obrar, se expandió la repulsa hacia toda glosa o comento, por considerar que la interpretación distorsionaba el precepto. 
Aunque esto último solo aconteció con el avance del siglo XVIII, no es extraño que, mucho antes, encontremos sus raíces.

Se asistía así en el siglo XVII a un estado de coexistencia entre estas dos vías principales de establecer el derecho. Coexistencia que escondía una disparidad que los tiempos posteriores revelarían en toda su intensidad. Entre los juristas despuntaban las nuevas ideas.

El proceso de elaboración de la Recopilación está enclavado dentro de una etapa de ordenación y consolidación jurídica de las Indias. Cabe entonces que nos preguntemos acerca del papel que se asignaba a aquellos modos de creación del derecho y de manera particular - en el asunto concreto que se aborda en estas páginas - sí para los juristas y ministros actuantes se concebía una recopilación legal desnuda de toda glosa, como único derecho, o si, en cambio, era preciso dar relieve a esa labor creativa - rica y a veces exuberante - de los juristas. El interrogante planteado no es una abstracción o especulación que hoy hacemos, sino que está en la trama de la vida jurídica de entonces, como puede detectarse a través de algunas huellas que han quedado en los documentos conocidos. Se trata de un interrogante de trabajo que ha estado ausente en la "historiografía legalista", carente de sensibilidad para apreciar otro Derecho y aun para verificar y seguir esa puja sutilísima que, dada en la época, conduciría finalmente al triunfo de una concepción eminentemente legalista del fenómeno jurídico. En qué medida leyes y autores convergen o se enfrentan en este episodio es asunto al cual procuraremos acercarnos en las páginas siguientes.

\section{Las leyes entretejidas con los autores: ¿una recopilación con glosas?}

Según afirmaba don Rodrigo Aguiar y Acuña en 1628, el presidente del Consejo de Indias, licenciado Fernando Carrillo, pretendió que "no sólo habíamos de acabar los dos esta Recopilación, sino que había de salir glosada, o por lo menos concordada con las Leyes Reales y Derecho Común" Esta expresión, estampada en la dedicatoria al rey que encabeza los Sumarios de la Recopilación, fue puntada inicial de esta indagación, al revelar la existencia de un criterio distinto al más conocido y estudiado de una recopilación exclusivamente legal.

La frase de Aguiar se inserta dentro de un contexto desfavorable para dicho criterio, ya que le sirve para excusar la disminución de las tareas 
legislativas durante la época en que el licenciado Carrillo presidió el Consejo, entre 1617 y 1622 . Aguiar agregaba que tal estudio "pedía una vida muy larga y libre de otras ocupaciones”. Además se quejaba de que ni siquiera el presidente había dispuesto del tiempo necesario para tomar conocimiento del estado en que se encontraba la obra.

Despuntan aquí, entre quejas y justificaciones, dos criterios para encarar la tarea recopiladora. El de Aguiar - que se encarnaría en León Pinelo - reducido a trabajar con el material legislativo, novedoso y abundante por cierto. Su proyección se confunde casi con la "historia clásica" de las recopilaciones indianas.

En cambio, el criterio atribuido al presidente Carrillo no tuvo esa proyección, pero es de interés ahondar en el mismo, dado que no se trataba de un capricho ni de una opinión enteramente personal. La idea en sí formaba parte del modo de obrar predominante donde - según hemos visto - la labor de los juristas apuntaba a la conjunción de leyes y autores. Manzano sospecha que la idea comentarista de Carrillo estuvo inspirada en una carta de Solórzano enviada al rey en $1618 .{ }^{12}$ Lo cierto es que esta idea, que conocemos tan sucintamente, comprendía dos posibilidades, una más ambiciosa, que era la glosa, y otra de alcance más corto, que era la concordancia con las Leyes Reales y el Derecho común. En ambos supuestos, la jurisprudencia de los autores aparecía de manera relevante.

Cabe preguntarse hasta qué punto una recopilación de estas características satisfacía las aspiraciones de los juristas y, sobre todo, si el modelo antiguo era aplicable en el ámbito indiano. El caudal documental ofrecido para responder a este interrogante es muy escaso. Debemos conformarnos con estrujar unos pocos textos, con percibir actitudes, con valorar silencios y, en fin, con no descuidar el contorno que rodeaba a estas inquietudes.

El único intento conocido, de elaborar una recopilación acompañada de glosas fue tempranamente emprendido por Juan de Solórzano Pereira, durante los años en que se desempeñó como oidor de la audiencia, en Lima. En el memorial que enviaba al rey en 1618, explicaba que "al pie de cada ley voy poniendo de dónde se saca, haciendo un historial y compendiosa relación de todo lo que se halla proveído en el punto que se decide que sirva juntamente de glosa y comprobación” y agregaba más adelante: "No me

12 Manzano Manzano, Historia..., cit., vol. II, p. 38. 
fuera dificultoso hacer más extendidos comentos, pues casi todo lo necesario para ellos se puede sacar de los otros libros latinos; pero tengo por mejor que vayan de por sí". ${ }^{13}$

Según se advierte, Solórzano ofrecía dos posibilidades de hacer la glosa: una, centrada en las disposiciones reales; y otra, más amplia, con mayor despliegue jurisprudencial. Para el proyecto en elaboración optaba por el primer camino, pero es necesario tener en cuenta que esta elección estaba enlazada con la concreción de la segunda alternativa en una obra que preparaba por separado. El mismo Solórzano, en otra carta del año siguiente, recordaba que había ofrecido "unos libros latinos que tengo escritos, y voy perfeccionando, que tratan de todos los puntos y materias particulares del derecho y gobierno de estas Indias, y una recopilación en romance de las cédulas, cartas y ordenanzas que se han despachado para ellas". ${ }^{14}$ Este párrafo da unidad de concepción a la idea solorciana. Si de una parte preferiría una recopilación legislativa con la glosa circunscrita a los textos recogidos, por otra daba cauce al despliegue jurisprudencial en los libros que tenía muy adelantados. De tal manera, el ensamble de leyes y autores se daba en planos distintos.

Acudamos al proyecto recopilador de Solórzano para apreciar su textura. El mismo, del cual solo se conoce el libro primero, fue publicado por Ricardo Levene en 1945 en la serie documental del Instituto de Historia del Derecho bonaerense. Pese al valor que encierra, no ha sido objeto de detenido examen, ${ }^{15}$ ni tampoco utilizado con frecuencia en la labor de investigación. Me ceñiré a destacar solo lo que es pertinente a los fines de esta indagación.

¿En qué consistía lo que Solórzano denominaba "glosa y comprobación"? En cada ley formada iba indicando de dónde había sido sacado (real provisión, pragmática, real cédula, ordenanzas, carta, instrucción, etc.) de modo global o en cada una de sus partes. Agregaba una relación de esas disposiciones con frecuentes comentarios acerca de las circunstancias que la origi-

13 Juan de Solórzano Pereira, Libro primero de la Recopilación de las cédulas, cartas, provisiones y ordenanzas reales. Noticia preliminar de Ricardo Levene, Instituto de Historia del Derecho Argentino (Buenos Aires, 1945), t. I, p. XXII. En esta transcripción, como en las restantes incluidas en esta colaboración, se ha modernizado la ortografía.

14 Carta al Rey, Lima 20 de abril de 1619 (Archivo General de Indias, Lima, 96).

15 Excepción es el capítulo que le dedica Manzano Manzano, Historia..., cit., vol. II, p. 31-61. 
naron y también de las consecuencias que tuvieron. Había glosas extensas y otras diminutas, en que se limitaba a referir la disposición de donde había sido extraída.

Muchas de las glosas constituían una madura elaboración apoyada en leyes, costumbres, prácticas. Planteaba dudas, señalaba contradicciones y avanzaba interpretaciones. Pero parecía buscar siempre un estilo ceñido, sin excesivas citas ni sutiles pensamientos. Esta actitud se veía favorecida por tratarse, en la mayor parte de los asuntos comprendidos en este libro del proyecto, de materias nuevas, donde no cabían remisiones directas a los autores del Derecho común o a las Leyes de Castilla. En algunas ocasiones, Solórzano se apoyaba en los teólogos o en otros escritores de Indias, y no faltan algunas remisiones a su De Indiarum Iure. En lo fundamental, todo pasaba por la disposición real, que era así el meollo de la ley recopilada. Hasta el propio Derecho canónico - pontificio e indiano - pagaba ese tributo.

Esa glosa aparece pues renovada con relación a la clásica, por tratarse precisamente de una materia novedosa y por encontrarse en un nivel normativo donde la disposición real iba asumiendo una posición directiva. En tal sentido podría establecerse una distinción con relación a las aspiraciones expuestas por el presidente Carrillo. A través de la forma en que ha llegado hasta nosotros, la idea de este aparecía inclinada hacia un tipo de glosa genérica y universal, como si las leyes indianas pudiesen entrar fácilmente en el molde del Derecho común. El modelo solorciano, en cambio, reflejaba una razón operativa, apoyada en el saber y la experiencia indianos.

Si bien el proyecto del oidor limeño no avanzó en su realización, es probable que la idea inspiradora y aun el modelo ofrecido siguieran pesando entre los ministros del Consejo. Puede conjeturarse un buen respaldo en el alto organismo indiano si tomamos en cuenta ciertos hechos y de manera más concreta un documento emanado del propio Consejo en 1637. Se trata de la consulta del 3 de octubre de dicho año, en la cual se hace una valoración de la labor legislativa de Solórzano, al justificar que permaneciera como único ministro encargado de la Recopilación, especialmente - dice - "por la entera satisfacción que de la ciencia e inteligencia de ella se tuvo y tiene de dicho don Juan de Solórzano, así por haber estado tantos años en las Indias como porque desde el 618, en carta que escribió al Consejo, le ofreció esta misma recopilación, juntamente con unos libros latinos que ha impreso, y está imprimiendo que sirviesen de glosa de ella, y envió la traza y forma 
como la tenía dispuesta y algunos títulos puestos ya en orden para que por ellos se conociese mejor su utilidad". Y enseguida se agregaba: "Lo cual todo pareció ser muy importante para el intento que el Consejo llevaba en ella: y así se le ordenó lo continuase, como lo ha ido haciendo". ${ }^{16}$ Es cierto que este documento no puede ser examinado en forma aislada. Tanto García-Gallo ${ }^{\mathbf{1 7}}$ como Manzano ${ }^{18}$ lo han insertado dentro del complejo proceso recopilador con los fines de desarrollar sus propias tesis. Las palabras transcritas son, a mi juicio, patente testimonio del aprecio con que los consejeros observaban esa labor impulsada por Solórzano, en la cual se conjugaban leyes y autores. Esto solo es lo que cabe dejar aquí apuntado.

\section{Las obras jurisprudenciales, una historia paralela}

El proceso formativo de la Recopilación no puede, a mi juicio, ser enteramente comprendido si se prescinde del desenvolvimiento paralelo de la jurisprudencia de los autores. En este sentido, durante la época que cae en nuestro enfoque se editaron dos obras jurisprudenciales básicas del Derecho indiano, ambas de Solórzano: el De Indiarum Iure, cuyo primer volumen se imprimió en 1629 y el segundo en 1639, y la Política Indiana, que salió de las prensas en 1647. En la génesis del proyecto solorciano, los dos tipos de obras, la jurisprudencial y la legislativa, integraban un mismo conjunto. Tal era según vimos - la idea expresada en la carta de 1619, en la cual se refería a "unos libros latinos que tengo escritos, y voy perfeccionando, que tratan de todos los puntos y materias particulares del derecho y gobierno de estas Indias, y una recopilación en romance de las cédulas, cartas y ordenanzas que se han despachado para ellas". Además de mostrar el engarce entre ambos tipos de obra, esta frase pone en evidencia una cierta relevancia de la primera de ellas, al asignarle un conocimiento pleno en cuanto que se ocupaba de "todos los puntos y materias particulares del derecho y gobierno de estas Indias". Refuerza este punto de vista otra expresión del mismo Solórzano, quien, muchos años después, al presentar la Política Indiana decía que "no sé si otro que yo pudiera haber dicho tanto, ni tocado, y resuelto tan variados

16 Torre Revello, Noticias..., cit., apéndice, p.VI.

17 García-Gallo, “La Nueva...”, cit., pp. 583-584.

18 Manzano Manzano, Historia..., cit., vol. II, pp. 133 y ss. 
puntos y cuestiones, y dado alcance, y nueva luz a tantos millares de cédulas, y ordenanzas reales, como en esta Política se hallan alegadas y declaradas...." Es decir, un Derecho reducido a los preceptos legales era inexpresivo, necesitaba ser animado, explicado e iluminado por esa ciencia que poseía el jurista, que se encerraba en el arte de la jurisprudencia. Todo esto no impedía reconocer el valor que Solórzano asignaba a las leyes para crear Derecho, como repetidamente lo podemos observar en sus escritos.

Es preciso apuntar otra circunstancia que obliga a mantener nuestra observación bifronte de leyes y obras jurisprudenciales en este proceso recopilador. Llama la atención que, durante el período en que se publicaron estos libros fundamentales, el Consejo no evidenció un decidido interés por imprimir la Recopilación acabada en 1636, ni por continuar la edición de los Sumarios. Puede reforzarse lo dicho con otra anotación, que merecería ser indagada en particular. Mientras parece que en el Consejo hubo disposición - y hasta recursos pecuniarios - para apoyar la edición de los libros de Solórzano, en cambio el dinero no apareció, o fue escamoteado, cuando se trataba de imprimir aquellos cuerpos legales ¿Era que aquellos ministros daban prevalencia a la línea jurisprudencial sobre la legislativa? Esta comprobación nos conduciría, al menos, a considerar que la Recopilación no era mirada entonces por dichos consejeros como el único modo de ordenar el gobierno y justicia en las Indias, contrariamente a lo que ocurriría después, según veremos, y también contrariamente a lo que daría por supuesto, en nuestros días, la historiografía jurídica.

\section{Las leyes como "verdadera jurisprudencia"}

Otra postura era la de quienes, exaltando a las leyes como la "verdadera jurisprudencia”, estimaban que la Recopilación no debía llevar glosas ni comentos. En la medida en que esta tendencia se fue definiendo, significó una ruptura con la concepción vigente y un avance hacia la exaltación del Derecho legal, aunque no siempre lo hayan percibido de este modo los propios protagonistas. Es posible fijar esta postura en torno a la figura de Antonio de León Pinelo.

19 Solórzano Pereira, Política Indiana (Madrid, 1647). "Al rey nuestro señor don Felipe IV en su Real y Supremo Consejo de Indias". 
Como es sabido, León fue el gran artífice de la Recopilación, a través de una paciente y esforzada labor de revisión de los libros registros-cedularios del Consejo. Escogió de allí el material legislativo con criterio jurídico e idoneidad singulares. Primero lo hizo como ayudante de Aguiar y, tras la muerte de éste, prosiguió solo la tarea hasta presentar el proyecto al Consejo en 1535. En ese largo trato cotidiano con las cédulas fue madurando una concepción enaltecedora de este tipo legislativo, convertido en el centro de sus preocupaciones jurídicas. Inclusive llegó a asentar los fundamentos de su preferencia en relación con la jurisprudencia de los autores. Este criterio ya lo encontramos insinuado en la pluma de Aguiar, cuando expresaba su oposición a aquella idea del presidente Carrillo de hacer una recopilación con glosas, pero carecía de sustento teórico y solo atendía a motivaciones prácticas.

Para acercarnos al hilo conductor de esta postura, disponemos de unos testimonios significativos, en los cuales - que yo sepa - no se ha reparado. Son los escritos, redactados entre 1628 y 1629, incorporados como páginas iniciales del Tratado de confirmaciones reales del licenciado León Pinelo, publicado en $1630 .^{20}$ En estos años sucedieron varios hechos que conviene recordar: en 1628 aparecieron los cuatro primeros libros de los Sumarios; en marzo de 1629, Antonio de León era promovido a relator del Consejo, aunque por el momento ostentaba solo el título y no la plaza; en octubre del mismo año moría Aguiar y Solórzano era designado en su lugar. ${ }^{21}$ Es difícil concatenar aquellos escritos con estos hechos, dada la proximidad y hasta el probable entrecruzamiento de unos y otros. Pero lo que se observa con nitidez es que en ese período ocurrieron sucesos decisivos para la marcha de la Recopilación y, por ende, para las dos líneas de pensamiento acerca de cómo debía realizarse. La muerte de Aguiar significaba un repliegue para el proyecto de recopilación legal, mientras la promoción de Solórzano daba respaldo a la otra línea. El titulo de relator otorgado a León era una recompensa y, a la vez, le permitía afianzarse dentro de la burocracia cortesana. En este nuevo marco, pues, deben apreciarse los testimonios que traigo a colación.

20 Antonio de León, Tratado de confirmaciones reales de encomiendas, oficios y casos, en que se requieren para las Indias occidentales (Madrid, 1630). Utilizo la edición facsimilar del Instituto de Investigaciones Históricas. Universidad de Buenos Aires (Buenos Aires, 1922).

21 Manzano Manzano, Historia..., cit., vol. II, pp. 128-129; Torre Revello, Ensayo..., cit., apéndice $n^{\circ} 5$. 
Los aludidos escritos trascienden la materia concreta de la gran obra en la que se insertaron. No es precisa demasiada agudeza para percibir que sus redactores estaban pensando en otros destinatarios que no eran los lectores corrientes de la obra y en otras cuestiones, a las cuales apuntaban algunos de sus filosos juicios. Se buscaba sobre todo fortalecer la postura favorable a una recopilación enteramente legal.

Cuatro son las piezas testimoniales que juzgo de interés, a saber: la censura aprobatoria del licenciado Aguiar y Acuña, la dedicatoria del autor al ministro don Lorenzo Ramírez de Prado, la introducción que suscribe el licenciado don Francisco de Barreda, relator del Consejo, y el prólogo del doctor Juan Rodríguez de León, hermano del autor. Sobre estos dos últimos escritos puede caber la sospecha de que su redactor fuese el propio Antonio de León, conforme al conocido artificio usado en la literatura de la época. ${ }^{22}$ Presunción que estimo bastante probable en este caso, pero aunque así no fuese, en nada disminuye el valor testimonial que poseen, dado el momento y lugar donde aparecieron estampados.

El ministro Aguiar, al dar su aprobación como censor del Consejo, decía que el libro "es el primero que ha salido a la luz de materias legales de las Indias, y está escrito con muy gran cuidado y advertencia, y circunscrito a las leyes y ordenanzas de las Indias muy doctamente”. Dictamen breve y elogioso, que podría pasar inadvertido. Pero si tenemos en cuenta el clima que rodeaba al ministro en el momento de hacerlo, se aprecia el énfasis con que destaca que una materia indiana podía tratarse "muy doctamente" reduciéndola a las leyes y ordenanzas. ¿No se esconde aquí una filosa respuesta a alguien? Esta misma puntualización, aunque en tono más suave, se verifica en la reverente dedicatoria que el autor hizo a su mecenas, el ministro Ramírez de Prado, al decir que el contenido del libro se refiere a lo que "por leyes, cédulas y ordenanzas reales está dispuesto y se practica en aquellas provincias" en materia de confirmación de encomiendas y mercedes, ventas y renunciaciones de oficios y otros casos; y que él había procurado "reducir a principios ciertos y reglas generales derecho tan irregular como el de Indias".

Donde asoman los conceptos más sustanciales es en el texto suscrito por el licenciado Barreda. Sostenía, como tesis central, que el estudio del Derecho romano y, particularmente, de los autores formaban al jurisconsulto propor-

22 José Simón díAz, El libro español antiguo: análisis de su estructura (Kassel, 1983), pp. 144 y ss. 
cionándole la ciencia y adiestrándolos en el conocimiento y distinción de lo justo, pero - agregaba - "la verdadera jurisprudencia" estaba en las leyes particulares de los reinos, que eran tan diferentes a las romanas por la época y el lugar. Ello lo llevaba a redondear el elogio del autor del Tratado objetivo último de este ensayo - preguntándose “¿Quién podrá negar gloria más grande, y mayor alabanza, al que con claro método, nos entrega las leyes, en torno de quien anda su ingenio y su erudición?". Es en estas leyes donde "como en ejemplar, o en idea, hallara desatadas todas las dudas, que la curiosidad ambiciosa de los maestros redujo a nudos, y embarazos". Era en la ley donde estaba el Derecho y no en los comentarios, según expresaba en este delicioso párrafo barroco: "No es segura la resolución del consulto, que no se colige de alguna ley: luego en la ley estaba la resolución. Flaqueza es de los ojos, no mirar al sol en su orbe; sino en las resultas últimas de la luz. Queremos conocer el Derecho por la reverberación del Derecho en comentarios; rodeo es de flacos ingenios. Al mismo Derecho habíamos de mirar, viéramos unidas las luces, que después se dilatan a espacios inmensos".

Bajo estas palabras, envueltas en fina alegoría, asomaba una actitud a todas luces contraria a la que prevalecía en la práctica del Derecho en aquel primer tercio del seiscientos. Si por una parte se halagaba y daba ancho cauce al "poderío real" en creciente aumento, por otra se juzgaba con mucha dureza a la jurisprudencia de los autores, núcleo del Derecho de entonces.

De la cuarta pieza testimonial - suscrita por el hermano de Antonio León - extraigo algunas expresiones que juzgo de interés para el cometido propuesto. Luego de enaltecer el valor de las leyes en la antigüedad y también entre los aborígenes americanos, decía que los naturales de las Indias sólo tenían, al ser juzgados, el amparo de "las leyes con que son defendidos", saliendo empero "no pocas veces agraviados, porque en la memoria de los jueces faltó la ciencia de las cédulas, que no todos alcanzan”. Y agregaba de inmediato: "Escrúpulo que movió al Real Consejo de Indias a comenzar a publicar la Nueva Recopilación de ellas, en que el autor de este libro ha trabajado siete años, siendo necesarias tantas vigilas, para vencer tan difícil estudio". No parece inocente la inserción de la expresión "la ciencia de las cédulas" con el agregado de que no todos la alcanzan, seguido de la referencia a la intensa labor de León en la obra recopiladora. A través de estas palabras parece articularse una respuesta a críticas u observaciones, bien dirigidas a los Sumarios o de manera global al proyecto legislativo en ejecución. 
El tono algo desafiante que rezuman estas páginas llega aún más lejos cuando al señalar los elementos que complementan el estudio de las cédulas, omitiendo a los autores, indicaba que eran la experiencia y la historia, saberes en los cuales - se decía - León era un entendido no solo por sus estudios sino por sus comprobaciones personales.

No parece casualidad que, a través de estas cuatro piezas de factura distinta, se pueda hilvanar un discurso común, del cual despunta el valor absoluto otorgado a las leyes reales en detrimento de la fuerza jurídica de los autores, relegados a desempeñar una función formativa. Todo ello se presenta como una cuestión novedosa y propia del ordenamiento indiano. Que en las leyes residiese "la verdadera jurisprudencia" y que se empleara la expresión "ciencia de las cédulas" para designar al conocimiento de las mismas, nos alerta sobre la existencia de una operación intelectual que, al dar señales de una vigorosa presencia, avizora también las resistencias que se levantaban a su alrededor.

\section{6. ¿Una puja silenciosa?}

Delineadas esas dos expresiones discordantes respecto al modo de establecer el Derecho, con directa repercusión en la Recopilación en ciernes, es conveniente observar lo que ocurrió en el seno del Consejo de Indias después de la muerte del ministro Aguiar y Acuña en 1629. El proceso ha sido estudiado en detalle por Juan Manzano, en base a la documentación conocida, quien suplanta con una razonada interpretación las lagunas y oscuridades de los papeles, con la única salvedad de que en la época que escribió la obra no pudo conocer el texto del proyecto de Léon Pinelo.

Del mencionado estudio queda en claro, de una parte, el empeño de León Pinelo, primero por concluir los Sumarios y luego el proyecto de Recopilación, que entregó al Consejo en 1635. Después de la revisión que practicó junto con Solórzano, al año siguiente, quedó acabado para su publicación. Desde entonces y casi hasta su muerte, ocurrida en 1660, fueron incontables sus gestiones para lograr la impresión. De otra parte, es palpable el escaso interés puesto de manifiesto por el Consejo para que se prosiguiese la tarea encomendada a Aguiar, e incluso para continuar la impresión de los Sumarios. Esta actitud no se alteró ante un pedido de la Audiencia de Lima en 1633, para que se concluyese la publicación de los Sumarios, ni ante un 
decreto regio de 1637, que instaba al Consejo a imprimir a la mayor brevedad la Recopilación ya acabada y ofrecía los recursos para ello.

Es más, puede acaso percibirse una velada resistencia a impulsar dicha impresión. Pese a que en una consulta de 1644 se expresaba que "juzga el Consejo lo mismo que siempre, cerca de la importancia de la impresión de esta recopilación", no parece que se pusiese en las palabras ni en las acciones el empeño necesario para llevarla adelante. Las propuestas de impresión no se sostuvieron, los fondos que se reunieron luego se dispersaron. Lo más sintomático ocurrió en 1645 cuando el Consejo desestimó la interesante oferta del obispo Juan de Palafox para hacerla en México. Se adujo para ello que la Recopilación estaba ya para entrar en las prensas.

De la percepción de desinterés que muestran estas actitudes es difícil avanzar. Desconocemos la vida interior del Consejo, así como el juego de influjos y liderazgos dentro del cuerpo. No es fácil determinar la actitud de Solórzano y su posible ascendiente sobre sus colegas, al menos hasta su jubilación en 1645. Solórzano es precisamente hombre clave en este asunto, no solo por la preocupación siempre demostrada, sino también por haber revisado, junto con León Pinelo, el proyecto elaborado por éste. En el certificado que expidió en 1637, como comisario de la Recopilación, fue complaciente en el elogio del autor y reconoció la importancia de la impresión y publicación de la obra. Hasta en su Política Indiana se encuentran abundantes referencias a la inminente impresión de la Recopilación. ${ }^{23}$

Pese a que Solórzano era quien estaba mejor compenetrado del sentido y utilidad de la obra, no hay huellas que permitan entrever su interés en impulsar la idea dentro del Consejo. ¿Se trataba de recelo o malquerencia hacia León? ¿Era que no compartía el criterio legalista que dominaba el proyecto en 1636? No existen pruebas - ¿acaso solo sospechas? - para sostener lo primero. En cambio, algunos testimonios pueden respaldar lo segundo. No parecía, pues, Solórzano un enemigo de la Recopilación, pero el punto de atracción se había desplazado hacia sus obras jurisprudenciales, en donde radicaba su gloria literaria. ${ }^{24}$

23 Sobre esto véase García-Gallo, “La Nueva...”, cit., pp. 536 y ss.

24 Es interesante al respecto ver Enrique García Hernán, Consejero de ambos mundos. Vida y obra de Juan de Solórzano Pereira. (1575-1655). Fundación Mapfre (Madrid, 2007), pp. 174-178. 
Da que pensar que la mala estrella del proyecto de León se extendiera casi hasta la muerte de Solórzano en 1655. ¿Es que el gran jurisconsulto ejercía una verdadera influencia sobre el sentir del Consejo en esta materia? Omisiones, ambigüedades, demoras, todo coincide en establecer una pronunciada indiferencia, cuando no resistencia, a concretar la postergada impresión. Atribuir todo ello a la disconformidad con el modelo recopilador sería aventurar un juicio sin sólido respaldo, porque, en efecto, nunca el Consejo manifestó claramente su oposición a dicho proyecto. Pero sin la posibilidad de ir más allá de la conjetura, la sensación de que durante muchos años se extendió una silenciosa puja entre los dos criterios cobra cuerpo a medida que se penetra en el estudio de este complejo proceso.

\section{Impulso al modelo legalista}

El enfoque de esta cuestión se percibe con más claridad cuando, por contraste, tras esta "larga espera", a partir de 1654, el Consejo, siempre a instancias del infatigable León, retomó con renovado interés la posibilidad de imprimir la Recopilación. Tal vez, nuevos aires inundaban el alto organismo. Lo cierto es que estaban ya en circulación obras jurisprudenciales, pero faltaba completar el conjunto con la Recopilación. La idea de Carrillo y el modelo solorciano no habían producido fruto palpable. El único que se tenía acabado era el proyecto de 1636. Todo ello incidió, sin duda, en el ánimo de los consejeros y condujo finalmente al pronunciamiento de factura legalista patentizada en la consulta del 11 de agosto de 1660, que expresa un cambio con relación a la postura tradicional. Atendamos a unos párrafos sustanciales en tal sentido. Decía, en efecto, que "como siempre se ha reconocido no puede gobernar el Consejo lo que está debajo de su jurisdicción con el acierto y justificación que se debe faltando la luz y noticia, de las leyes, cédulas y ordenanzas municipales que V. M. y sus gloriosos progenitores han mandado despachar tan santa y prudentemente para el mejor gobierno y administración de justicia de las Indias...”

No solo era cuestión de gobierno del Consejo. También lo era de las autoridades y vasallos indianos. Así sostenía esta decisiva consulta que "ni los gobernadores saben las reglas que deben observar en el gobierno ni los jueces las leyes por donde han de juzgar ni los tribunales y ministros que administran la Real Hacienda la forma y orden que han de guardar en ello ni las partes las leyes de que se pueden valer para su defensa con que faltando 
todo esto viene a ser grande la confusión y desconsuelo de los ministros y vasallos de aquellos reynos pues sin leyes ningunos pueden ser bien gobernados..." Por lo tanto, proponía al rey "la suma importancia de concluir esta obra y que este cuidado debe anteponerse a todos..." aun sacrificando los gastos más esenciales con tal de obtener el caudal para su impresión, pues lo merecía una obra de "tan grande importancia y que ha de ser tan Universal" ${ }^{25}$ Manzano hace este ajustado comentario a texto tan expresivo: "Jamás hemos visto al Consejo tan decidido como en la ocasión presente a coronar la gigantesca empresa que había tomado a su cargo. Al menos, en ningún tiempo anterior ha empleado en sus consultas al monarca un lenguaje tan contundente."26

La lectura de esta consulta nos coloca frente a un texto inspirado resueltamente en aquella línea legalista que descubríamos en los escritos publicados en 1630. Era necesario dar un cuerpo legal para iluminar el gobierno y la justicia en Indias, porque sin el mismo "se camina ciegamente", se produce "la confusión y desconsuelo" de ministros y vasallos. La fuerza del estilo, la contundencia de los conceptos eran desusadas en la historia de este proceso, como lo corrobora el profesor Manzano. Según este autor, el principal propulsor de esta nueva instancia del movimiento recopilador fue el flamante gobernador del Consejo, don José González Caballero, y aunque su corta permanencia en el cargo incidió para que el ritmo de los trabajos de revisión disminuyera, y por momentos pareciera detenerse, la senda abierta por esta consulta de 1660 no fue entorpecida hasta la sanción real y publicación de la Recopilación, tal como la conocemos.

\section{Apuntes finales}

De aceptarse el encuadramiento e interpretación realizados en las páginas precedentes, se podría decir que estamos en presencia de uno de los tantos episodios de la secular tensión - más o menos sigilosa - entre estos dos modos principales de establecer el Derecho, entre la prevalencia de la materia legal o jurisprudencial. Bajo este enfoque, podrían tal vez articularse mejor los hechos y las palabras, sin pretender obtener por esta vía una explicación total.

25 Torre Revello, Ensayo..., cit., apéndice $\mathrm{n}^{\mathrm{0}} 7$.

26 Manzano Manzano, Historia..., cit., vol. II, p. 248. 
Estas ideas disonantes parecen desplegarse en torno a dos figuras centrales. Solórzano y León Pinelo. No pertenecieron a una misma generación, ya que el primero le llevaba unos quince años en la edad, pero actuaron coetáneamente entre 1620 y 1655 , tiempo en el cual la elaboración del Derecho indiano tuvo su época de oro, tanto en el aspecto legal como en el jurisprudencial. Solórzano se jubiló en 1645, pero continuó vinculado al Consejo, pues se le requirieron dictámenes hasta avanzado el año 1653. Murió en 1655. En cambio, la actividad de León continuó un tiempo más, y falleció en 1660 .

La corriente que enaltece la elaboración jurisprudencial se configura en torno a Solórzano, a través de sus obras De Indiarum Iure (1629 y 1639) y Política Indiana (1647). Con ellas se atendía razonablemente al problema del Nuevo Mundo, pues se encontraban allí tratados - como había dicho en 1619 - "todos los puntos y materias particulares del derecho y gobierno de estas Indias”. Aunque esta corriente englobaba también la posibilidad de imprimir una recopilación de leyes glosada - tal era la idea inicial del propio Solórzano -, es evidente que con el transcurso del tiempo parece quedar satisfecha en aquella producción jurisprudencial. Puede conjeturarse que este pensamiento aparece como dominante en el seno del Consejo, tal vez bajo el influjo solorciano, hasta casi la muerte del jurista. Es la época durante la cual - según lo he puntualizado - los consejeros no demuestran mayor interés por la impresión de la Recopilación preparada por León, y hasta adoptan en algún momento una actitud próxima a la oposición cuando se ofreció una posibilidad cierta de llevarla a cabo. No aparece por entonces ninguna declaración del Consejo que relacionara el desgobierno de las Indias con la falta de una recopilación legislativa.

Así como Solórzano empezó trabajando paralelamente en los proyectos legislativo y jurisprudencial, también Antonio de León, con una buena formación humanista, se nos presenta en ambas sendas pero, resignando sus intentos iniciales de escribir una obra de conjunto sobre las Indias, ${ }^{27}$ concretaría paulatinamente sus energías en la labor legislativa, haciendo de

27 Tal era su proyectada Política de las Grandezas y Gobierno del Supremo y Real Consejo de las Indias, cuyo esbozo se plasmó en un opúsculo impreso en 1624 o 1625. Reproducción facsimilar en Revista de Historia del Derecho, $\mathrm{n}^{\circ} 11$ (Buenos Aires, 1983), pp. 509-560 con advertencia de Víctor Tau Anzoátegui. 
la misma el centro de su actividad durante muchos años y también el meollo de su concepción jurídica. Su proyecto de Recopilación, revisado por Solórzano, acabado y puesto en condiciones de ser impreso no encontró, sin embargo, vientos favorables en el Consejo para este último paso. La impresión de la Recopilación no parecía un asunto urgente. Esta postura tardó en modificarse y, solo en 1660, encontramos una decisiva declaración, a través de la cual la Recopilación aparecía como de primera necesidad para atender un supuesto estado de caos o confusión que afectaba al gobierno de las Indias. Para entonces también había muerto León Pinelo.

Pese a este expresivo cambio de postura, no debemos olvidar que estamos incursionando en una historia de matices, en la cual se avanza lentamente, sin que nada nuevo aparezca de súbito, sin que nada antiguo se desvanezca espectacularmente. No se puede decir que una corriente sustituye a otra. Así como durante el período del posible influjo solorciano la presencia legalista tenía su lugar - desde luego que también en el propio pensamiento del jurista madrileño -, así también durante la época posterior no podría decirse que el enfoque jurisprudencial fuese desplazado. Mientras la Recopilación fue ganando autoridad en el orden jurídico indiano, no por eso dejó de acudirse, e invocarse como Derecho, a las obras jurisprudenciales.

Frustrada la idea de hacer una Recopilación glosada, con todo, la Recopilación meramente legal y las obras jurisprudenciales citadas fueron elementos convergentes que contribuyeron a dar solidez al orden jurídico hasta entonces inestable. La solidez, claro está, propia de un ordenamiento casuista. En esta nueva mirada vuelven a asomar las figuras de Solórzano y León Pinelo como los artífices de esa perdurable labor creativa, pese a las diferencias que separaron algunos de sus puntos de vista. 


\section{El ejemplar, otro modo de creación jurídica indiana*}

Sumario: I. Planteo del tema - II. La noción de ejemplar - III. Su fundamentación jurídica - IV. Utilización del vocablo en la Política Indiana - V. Uso e invocación en el despacho del Gobierno Supremo - 1. La búsqueda de ejemplares, una tarea burocrática - 2. La fuerza jurídica del ejemplar - a) Fundamento de la decisión - b) El temor a su consecuencia - 3. Materias en que se invocaba - 4. ¿Cuántos eran necesarios? VI. Hacia el desplazamiento del ejemplar

\section{Planteo del tema}

El aporte que ofrezco continúa la línea de mis anteriores trabajos sobre las fuentes del Derecho indiano y procura ir mostrando los instrumentos de labor con que operaban los juristas de los siglos centrales de la Edad Moderna, en la fase de consolidación de dicho ordenamiento. La preocupación del jurista aparecía entonces dominada por la solución de los casos concretos y el uso e invocación de las diversas fuentes a su alcance se hacía conforme a la conveniencia de la argumentación y fundamentación, sin pretensión de establecer reglas universales y permanentes ni de plasmar una rígida jerarquía de los modos de creación jurídica que pudiera entorpecer su libre utilización. Necesitaba tener a su alcance la mayor cantidad de elementos jurídicos que apoyasen la solución adecuada al caso. ${ }^{1} \mathrm{Al}$ ubicar el ejemplar dentro de la mentalidad casuista imperante es preciso evitar cualquier ejercicio dogmático destinado a presentarlo como modo autónomo de creación jurídica.

El ejemplar era uno de los instrumentos que servía al jurista. Frente a la ley, la costumbre y la doctrina de los autores tiene indudablemente menor

* Publicado en Memoria del X Congreso del Instituto Internacional de Historia del Derecho Indiano, Escuela Libre de Derecho. Universidad Nacional Autónoma de México, México, 1995, t. II, pp. 1631-1656.

1 Víctor Tau Anzoátegui, "La doctrina de los autores como fuente del Derecho castellanoindiano", en Revista de Historia del Derecho, núm. 17, Buenos Aires, Instituto de Investigaciones de Historia del Derecho, 1989, pp. 356-357. Se reproduce en este volumen (V). 
relieve. A veces se halla infiltrado en el proceso formativo de estas fuentes. Su presencia no es posible separarla siempre de las demás vías de creación y de la argumentación jurídica. De ahí que resulta pretencioso y estéril tratar de elaborar un perfil purificado del mismo.

En mis indagaciones sobre las demás fuentes del Derecho indiano fui tropezando con alguna frecuencia con la voz ejemplar pero mis primeros registros no llevaban el propósito de realizar un trabajo específico sobre el tema. Sin embargo, esta labor marginal de recolección de datos me reveló la importancia que encerraba la cuestión, hasta ahora no destacada por los estudiosos del Derecho indiano. Se trata pues de una indagación que no fue planteada y programada desde el principio, con lo cual su ejecución ha quedado limitada a dos sectores concretos de la esfera jurídica: el examen de la obra jurisprudencial más saliente de todas, la Política Indiana de Solórzano; y el estudio de los despachos expedidos en el pináculo de la Monarquía, el rey y el Consejo de Indias. Sectores éstos que estimo altamente representativos e influyentes sobre el resto de la vida jurídica, por lo que la reducción del campo de estudio queda en parte compensada por el carácter destacado de esas áreas. Sería de mucho interés proseguir la investigación en otros sectores y particularmente en la múltiple actividad de gobierno y justicia local de las provincias indianas, sobre las cuales todavía es muy escaso lo que se conoce en esta materia. ${ }^{2}$

\section{La noción de ejemplar}

En nuestro enfoque prevalece el vocablo ejemplar en la acepción de "lo que ha ocurrido o se ha realizado en igual caso otras veces". Su comprensión se completa con la voz ejemplo en el sentido de "hecho, texto o cláusula que se cita para comprobar, ilustrar o autorizar un aserto, doctrina u opinión”, usada del siglo XIV en adelante. ${ }^{3}$ El enlace entre ambos nos lleva a unir el hecho en sí mismo con su plasmación literario-jurídica.

2 Véase referencias en Alberto David Leiva, "La aplicación de la media anata en el virreinato del Río de la Plata”, en Revista Chilena de Historia del Derecho, núm. 13, Santiago, 1987, pp. 271-273; y Abelardo Levaggi, "El concepto del Derecho según los fiscales de la Segunda Audiencia de Buenos Aires” en ídem, núm. 11, pp. 256-257.

3 Martín Alonso, Enciclopedia del idioma, Madrid, 1958. También en los ficheros de la Real Academia Española donde se reúnen fichas comprobatorias del uso de esta acepción con cierta amplitud. Es interesante al respecto, la definición que ofrece Sebastián de Covarru- 
Ejemplar y ejemplo eran - más allá de la esfera jurídica - elementos del saber universal de la época. Es conocido el recurso a los exempla en el pensamiento medieval, prolongado en los siglos modernos, aunque ya para entonces apareciera la crítica humanista. Maravall ha puesto de relieve la valoración que del ejemplo se hacía en los libros político-morales del siglo XVII español, en los cuales las tesis o pareceres se apoyaban en una relación de ejemplos, extraídos de la historia sagrada y profana o aún en hechos convenientemente imaginados. ${ }^{4}$

En la esfera jurídica, la noción de ejemplar mantiene - y si cabe, acrecienta - ese complejo entramado. Desde luego constituía un apoyo frecuentemente utilizado en la argumentación y en la construcción del discurso jurídico bajo formas de erudición, gusto estético y recurso histórico. Esto lo comprobaremos más adelante en la elaboración solorciana. Pero yendo al terreno de la creación del Derecho en sentido estricto, encontramos que el ejemplar aparecía con frecuencia junto a las principales fuentes del Derecho. Se puede así observar su vinculación a la ley, la doctrina de los autores y la costumbre bajo estos perfiles principales: a) como elemento en la decisión gubernativa o judicial, y en su caso como germen de la ley particular dictada a consecuencia de aquélla; b) como precedente que los autores utilizaban para fundar sus opiniones o construir el aparato institucional; y c) como prueba fehaciente en la formación de la norma consuetudinaria.

Es preciso señalar también el uso frecuente que alcanzó, en el mismo sentido, que nos interesa, la voz consecuencia, en cuanto expresa el hecho o acontecimiento que se sigue a resulta de otro. ${ }^{5}$ Una cosa trae consecuencia cuando puede alegársela por ejemplar de otra. ${ }^{6}$ Es decir, el ejemplar produce - o puede producir - consecuencia. No sólo se trata de una voz complementaria sino que en muchas ocasiones - en general antes de la segunda mitad del siglo XVII - reemplazó en los despachos reales al propio vocablo ejemplar. Así aparecen repetidas a menudo expresiones como "hágase así, mirando en que no sea consecuencia para otros"; "esto se habrá de mirar por ser

bias de la voz exemplo como "la comparación que hacemos de una cosa para apoyar otra" (Tesoro de la lengua castellana o española (1611), Ed. Barcelona, 1943, p. 575).

4 José Antonio Maravall, La teoría española del Estado en el siglo XVII, Madrid, 1944, pp. 56-57.

5 Concepción que M. Alonso ubica entre los siglos XVI a XX (Enciclopedia, cit., voz "consecuencia”).

6 Ibídem; María Moliner, Diccionario del uso del español, Madrid, 1960, t. I, p. 731. 
cosa de consecuencia" "porque no haya consecuencia se mirase en la forma que se ordena el despacho", "no conviene introducir esta consecuencia", o "excúsese por las consecuencias". En esas ocasiones se resaltaba el valor asignado al ejemplar, en cuanto a su fuerza como precedente.

La presentación de la noción que nos ocupa no queda acabada sin una breve referencia a su vinculación con el fenómeno consuetudinario, con el cual puede llegar, incluso, a confundirse.

El ejemplar aparece en este perfil como instrumento probatorio de la existencia de determinada costumbre, pero a menudo - sobre todo con anterioridad a la segunda mitad del XVII - expresiones contenidas en decisiones reales, tales como "hágase lo que se acostumbra en semejantes ocasiones" y otras similares, revelaría un uso indistinto de ambas voces. A esto se suman los vocablos práctica y estilo. Para determinar una práctica, se reunieron en 1773 catorce ejemplares provenientes de las Secretarías de Nueva España y del Perú, los cuales conformaban una práctica, que el Consejo acordó que "se siga inviolablemente".7 Algo análogo se observa con estilo. A raíz del pedido de merced formulado por la viuda de un oidor de la Audiencia de Filipinas, el rey inquiría sobre "lo que es estilo hacerse con las mujeres de los oidores en Indias" y luego respondía: "hágase lo que se acostumbra" ${ }^{8}$ La prueba de ese estilo reposaba en la existencia de ejemplares. Pese a esta proximidad de costumbre y ejemplar, la noción de éste no queda atrapada dentro del reducto consuetudinario, pues ofrecía otras exteriorizaciones.

\section{Su fundamentación jurídica}

Un jurista imbuido de legalismo podrá preguntar en qué disposición se fundaba el valor jurídico del ejemplar. La respuesta puede ser para él desconcertante. Esa fuerza provenía de la auctoritas que dimanaba de un saber reconocido y trasmitido a través de los siglos, que no estaba sujeto a discusión. ${ }^{9}$ De allí que, al menos hasta avanzado el siglo XVIII, el jurista no fuese

7 Archivo General de Indias (en adelante AGI), Indiferente General, 919.

8 Antonia Heredia Herrera, Catálogo de las consultas del Consejo de Indias, 1626-1630, Sevilla, 1987, núms. 623 y 648.

9 Sobre esto, Manuel García-Pelayo, “Auctoritas", en Revista de la Facultad de Derecho, núm. 42, Caracas, 1969, pp. 9 y ss. 
atraído por un tratamiento teórico de la cuestión, ni se sintiera necesitado de desplegar una argumentación al respecto. Así Bermúdez de Pedraza - en un libro para aprendices - decía sentenciosamente que en Derecho se admitía argüir "en tres maneras, o por ley, o por razón, o por ejemplo...." ${ }^{10}$ No parece que el jurista de entonces necesitara mayores explicaciones ni textos legales para afirmar lo que era una arraigada creencia.

Es posible, sin embargo, acudir a algunos testimonios que, de modo indirecto, confirman ese poder atribuido al ejemplar. De obras clásicas del Derecho hispano de la época extraemos pasajes significativos al respecto. En medio del discurso dialéctico se leen en la Política Indiana de Solórzano, frases como éstas: "lo que se hace siguiendo ejemplos antiguos y las pisadas de Varones prudentes, suele justificar las acciones humanas, como lo enseña el derecho, Cicerón y muchos otros Autores"; "lo que se hace siguiendo ejemplares, y más cuando son abonados, parece que tiene por sí la presunción del derecho" ${ }^{12}$ A su vez, de Castillo de Bobadilla rescato el sabroso párrafo que dedica a las pretensiones de los regidores de incrementar - frente al Corregidor - determinada prerrogativa. Decía el autor, en franco consejo amigable a los corregidores, que "lo que una vez se permite a los Regidores hace consecuencia para otra ocasión, y fúndanse en ejemplares de lo que otra vez se hizo en aquel caso". ${ }^{13}$ De estas lacónicas citas se desprende esa fuerza jurídica atribuida al ejemplar y el consiguiente temor a suscitar consecuencia derivada de los actos.

En un político de mediados del Seiscientos, Ferrer de Valdecebro, encontramos un desarrollo más explícito del tema, desde una perspectiva que no es enteramente ajena a la esfera jurídica. Afirmaba este curioso autor que en las Historias se encontraba "el manantial y fuente de toda la política", agregando que "en ella hallaréis ilustrísimas acciones, que seguir como ejemplares vivos de lo sucedido y prevenciones para lo que ha de suceder; y para el conoci-

10 Francisco Bermúdez de Pedraza, Arte legal para estudiar la jurisprudencia, Salamanca, 1612, p. 104.

11 Juan de Solórzano Pereira, Política Indiana (1647). Edición utilizada, Madrid, 1776, II, $\mathrm{XV}, 21$. En las transcripciones de este trabajo van destacadas en bastardillas palabras que interesan a nuestro tema.

12 Ídem, III, I, 17-20.

13 Jerónimo Castillo de Bobadilla, Política para corregidores y señores de vasallos en tiempos de paz y de guerra (1597). Edición utilizada, Madrid, 1775, III, VIII, 23. 
miento de todo el linaje de materias; experiencia, abundante, y presente de todos los gobiernos pasados". Más adelante proseguía: "Son los ejemplares de las Historias tan evidentes, como varios, en que se toma el pulso para sanar o mejorar el cuerpo del gobierno con notorias experiencias de lo sucedido. Y aunque hoy son los sucesos de tanta desigualdad a lo que pudo en los pasados siglos suceder, que muchos, ni aun en sombra sucedieron, tómase de los demás medio y motivo para deliberar el acierto, con que siguiendo este norte fijo, siempre se navegará por ciertos y seguros rumbos en el gobierno". ${ }^{14}$

Adviértase como Ferrer de Valdecebro presentaba al ejemplar, de una parte como norma catalizadora de la experiencia histórica, y de otra establecía su limitación al mostrar la fractura que separaba los ejemplos antiguos de los sucesos coetáneos. Pese a esta falla de naturaleza, consideraba que era un "norte fijo", siguiendo al cual "siempre se navegará por ciertos y seguros rumbos". Otro político, Setanti, daba la solución en uno de sus aforismos al decir que "a los ejemplares antiguos es menester acompañar con discursos nuevos". ${ }^{15}$ El ejemplar pues no servía como norma inmóvil, de mecánica aplicación, sino que era uno de los elementos que concurrían a la reflexión del político y del jurista, en trance de hallar solución adecuada a los casos nuevos. Era la época de oro del pensar casuista.

En el terreno de la praxis, encontramos algunas muestras expresas de ese poder reconocido al ejemplar. He reunido aquí tres textos entre fines del XVI y mediados del XVII, con cierto alcance expresivo por provenir precisamente de la autoridad real. En una respuesta que daba el rey, visiblemente preocupado, ante una consulta del Consejo acerca del permiso que solicitaba un oidor de Filipinas para casar a sus hijas, se lee: "Aunque con remitirlo al gobernador se justifica esta licencia no por eso deja de abrir puerta a una cosa desusada, y así se debe mirar mucho, pues se sabe cuanto pueden los ejemplares y que aun no habiéndolos procuran las partes hacerlos con su cuidado y importunación". ${ }^{\mathbf{1 6}}$ No tiene desperdicio esta grave advertencia que el rey

14 Andrés Ferrer de Valdecebro, El Superior. Política para todo linaje de prelados, Alcalá de Henares, 1663, pp. 162-163.

15 Joaquín Setanti, Centellas de varios conceptos, núm. 130, fs. 13v, obrita incluida en Benedicto Arias Montano, Aforismos sacados de la Historia de Publio Cornelio Tácito por..., Barcelona, 1614.

16 Heredia, 1600-1604, núm. 1707. 
daba a su Consejo, en donde queda plasmado el peso jurídico del ejemplar que destaco en el texto - y hasta el intento de formarlos cuando no los había. Toda la fuerza de esta respuesta real se dirigía a la cuestión en sí, no por cierto al caso planteado cuya solución particular no ofrecía, al parecer, inconvenientes.

De la misma época es otra consulta del Consejo con relación a la solicitud del tesorero de la Real Hacienda de Yucatán para que se le permitiese desempeñar el oficio no obstante haberse casado con una encomendara. El Consejo representó "algunas causas y ejemplares que para ello había", pero el rey dispuso: "Búsquese otra cosa, que no haga consecuencia para otros". Si respuestas de este tipo fueron frecuentes, el interés de este caso reside en que fue recogido tiempo después por Antonio de León Pinelo, junto con casi dos centenares de despachos, en una compilación impresa de autos, acuerdos y decretos del Consejo de Indias, ${ }^{17}$ convirtiéndose así en norma o regla con alcance más general.

Fue, sin embargo, un decreto de Felipe IV en 1622 el único que en nuestra materia, alcanzó el carácter de ley indiana, pues recogido en las Ordenanzas del Consejo de 1636, se incorporó finalmente a la Recopilación de 1680 (II, II, 20). Se trataba de una cuestión relativa a "pretensiones de partes" y su texto original se mantuvo al ser compilado. Bien vale su transcripción: "El consultar y resolver algunos negocios por la consecuencia de lo que se ha hecho en otros, trae consigo muy grandes inconvenientes, porque no en todos pueden concurrir unas mismas causas y circunstancias; y así encargamos a nuestro Consejo de Indias, que cuando hubieren de tratar y consultar negocios de esta calidad, y que se tuvieren por ordinarios, se advierta mucho el estado que las cosas tuvieren al tiempo que se tratare de ellas, y se hubiere de hacer la consulta, para que con esta consideración se traten y resuelvan las materias más ajustadamente." ${ }^{18}$

En estos textos reales se pone en evidencia, acaso más explícitamente en el primero, la fuerza reconocida al ejemplar, fuerza que escapaba al control de la autoridad real. En los mismos se procuraba evitar que los ejemplares abriesen puertas o sentasen consecuencias que limitasen la decisión de los

17 Autos, acuerdos y decretos de gobierno del Real y Supremo Consejo de Indias, Madrid, 1658, fs. $4 \mathrm{v}$ ( 8 de febrero de 1607).

18 Decreto originario de 26 de noviembre de 1622 en AGI, Indiferente General, 615. 
nuevos negocios. ¿Se esconde también la búsqueda de una mayor cuota de poder real? En el último texto - mucho más importante en cuanto era una instrucción dada al Consejo, con fuerza de ley - se ponía énfasis en destacar que los ejemplares no eran un precedente de mecánica aplicación, sino que era preciso tener mucho en cuenta "el estado que las cosas tuvieren al tiempo que se tratare de ellas”. Era la misma recomendación que hacían los políticos citados y compaginaba con una concepción casuista del gobierno indiano. El ejemplar ocupaba un lugar en la deliberación que acompañaba a todo proceso de decisión, pero no tenía - así se procuraba - el valor de precedente obligatorio.

\section{Utilización del vocablo en la Política Indiana}

Para examinar cómo opera la noción del ejemplar en la Política Indiana de Solórzano es preciso partir de dos supuestos: la estimación de la obra jurisprudencial como fuente directa creadora de Derecho y con función directiva sobre las restantes fuentes; y la apreciación de dicha obra como el más sobresaliente libro epigonal y fijador de la jurisprudencia indiana, que gozó de una autoridad extendida durante un siglo y medio. He escrito algunas páginas sobre estas cuestiones y a ellas me remito. ${ }^{19}$

Aun así quisiera reiterar y agregar breves consideraciones tendientes a ubicar mejor nuestro campo de análisis. La Política Indiana se elabora y publica en una época en que el Derecho indiano estaba ya desplegado en los niveles legislativo y jurisprudencial, aunque sus elementos componentes se hallaban dispersos. Entonces fue cuando se acometieron dos grandes esfuerzos paralelos: la compilación de leyes y la fijación jurisprudencial. Solórzano trabajó en ambos proyectos pero su labor se plasmó finalmente en la segunda vía con el éxito conocido, a través de De Indiarum Iure y sobre todo con la Política Indiana.

La obra, inmersa en la literatura casuista, aparece fortalecida por el influjo humanista y por un impulso racionalista. En su contenido se percibe la

19 "La doctrina de los autores...", cit., pp. 401-406; y "Elementos consuetudinarios en la Política Indiana de Solórzano", en Revista de Historia del Derecho, núm. 15, 1987, pp. 472-476. Este último estudio se reproduce en ídem, El poder de la costumbre. Estudios sobre el Derecho Consuetudinario en América Hispana hasta la Emancipación. Instituto de Investigaciones de Historia del Derecho, Buenos Aires, 2001, pp. 311-315. Hay versión electrónica de este libro de la Fundación Histórica Tavera, Digibis, Madrid, 2000. 
búsqueda de soluciones que fuesen conformes a las circunstancias y calidades de los casos ofrecidos. De ahí el despliegue de un abundante material de leyes, costumbres, opiniones, decisiones judiciales, lugares comunes o reglas vulgares de Derecho. La ilustración con adagios, apotegmas o emblemas ayudaba a sustentar el discurso jurídico. Los ejemplos o ejemplares se ubican dentro de esta amplia variedad de elementos convergentes. He registrado más de dos centenares de veces dichas voces - con predominio cuantitativo de la primera - con uso muy variado, del cual voy a señalar las principales manifestaciones.

Es frecuente la utilización de las citadas voces en la acepción de hecho histórico que ilustra una proposición o concepto y funda determinada opinión. Así se citaban ejemplos de naciones - romanos, chinos, etíopes, teutónicos, españoles, indios Americanos - o de otros reinos de la Monarquía Navarra, Aragón, Valencia, Cataluña, Nápoles - de textos sagrados, apóstoles, santos y romanos pontífices. No faltaban los ejemplos de emperadores, reyes, príncipes y otros hombres sobresalientes. De modo mucho más reducido, los ejemplos aparecían como alegoría - el cuerpo humano, el elefante y el castor, los dos galgos, la luna - y también como arquetipo o regla de conducta para los demás. En este último carácter se mencionaban a los caciques y a los religiosos doctrineros con relación a los aborígenes, y a San Vicente Ferrer y San Francisco Xavier como dechados de celo apostólico. Estos ejemplos no pertenecen estrictamente al campo de la creación del Derecho, pero no podríamos apartarlos de nuestro interés, dado que los mismos actuaban, individualmente o en conjunto, como apoyo jurídico, exorno literario o erudito de una obra jurisprudencial.

Si en el punto destaqué dos pasajes significativos en donde Solórzano afirmaba el valor que tenían los ejemplos o ejemplares en la creación jurídica, es conveniente ahora abundar en esa misma línea. Nuestro autor admitía reiteradamente a aquéllos como modo creativo al argumentar sobre la existencia de "textos y ejemplos", 20 "leyes y ejemplos", ${ }^{21}$ "textos, ejemplos y autores" 22 "razones y ejemplares," 23 "autores y ejemplos"24 en apoyo de lo sustentado en diversos pasajes del discurso. Al referirse a una opinión proba-

20 Política Indiana, III, XV, 10; y IV, IX, 28.

21 Ídem, II, XXI, 7; y III, XXIII, 31.

22 Ídem, III, II, 24; y V, IX, 42.

23 Ídem, III, II, 26; y V, XVII, 33.

24 Ídem, IV, XXVII, 30. 
ble decía que "tiene por sí tantos y tan sólidos ejemplares y fundamentos" 25 En otro pasaje afirmaba que eran tantos "en número y en autoridades los Doctores que siguen esta opinión, y la ilustran con razones, leyes, estatutos y ejemplares de todos los Reynos de la Cristiandad" ${ }^{26}$ No faltaba alguna sugerente expresión en el mismo sentido, como cuando afirmaba que "por estos ejemplos se podrá ir entendiendo y decidiendo" los demás casos que se ofreciesen en materia de bienes mostrencos, que había tratado de manera abreviada. ${ }^{27}$ También usaba dichos vocablos para referirse al caso o casos que por su parecido con el presentado ayudaban a fundar la solución. ${ }^{28}$ A través de estas citas se advierte que Solórzano ubicaba el ejemplo o ejemplar entre los modos de creación del Derecho.

El ejemplar aparece en otros pasajes de la Política Indiana conectado con la ley, la costumbre o la decisión judicial. Veamos algunas muestras de esta utilización. Cabe recordar, en primer lugar, aquel conocido párrafo en el cual Solórzano expresaba que como las leyes "no pueden comprender todos los casos, y puntos que ofrece su práctica, se traen y deben traer en argumento, y por vía de símil de unos a otros, y extenderse y ampliarse de casos a casos, todas las veces que su decisión o disposición está manifiesta en alguno de ellos, y corre en otros igualmente su misma razón, con que unas suplen por otras, y los que juzgan tienen ejemplares de qué valerse". ${ }^{29}$ La voz aparecía utilizada en este párrafo medular para designar a la operación de extender la ley casuista a otros casos análogos. ${ }^{30}$ Volvía otra vez sobre la cuestión cuando expresaba que era "válido, y tan frecuente en la constitución o extensión de las leyes y costumbres el ejemplo o argumento, que se toma de unas Provincias a otras, donde milita, o se puede ajustar y acomodar la misma razón”. Al decir esto estaba tratando acerca de la introducción del servicio de yanaconas en las Indias. ${ }^{31}$

Se puede también encontrar el ejemplo como apoyo de la costumbre. ${ }^{32}$ Cuando Solórzano presentaba la cuestión sobre si las mujeres podían suceder

25 Ídem, IV, I, 35.

26 Ídem, IV, XXVII, 16.

27 Ídem, VI, VI, 14.

28 Ídem, III, XXXI, 15; IV, II, 11; IV, XVI, 35; IV, XXVI, 34; V, IX, 3; y VI, XIV, 15.

29 Ídem, III, XX, 22.

30 Sobre el alcance que ello tenía en la jurisprudencia casuista, véase mi Casuismo y Sistema. Indagación histórica sobre el espíritu del Derecho Indiano, Buenos Aires, 1992, pp. 339 y ss.

31 Politica Indiana, II, IV, 17.

32 Ídem, III, IV, 28; y IV, II, 29. 
en los cacicazgos, afirmaba que, ateniéndose a los mayorazgos, la respuesta era afirmativa, pero en las Ordenanzas de Toledo se prefería a los varones. De ahí que en la mayoría de las provincias del Perú, éstos excluían a aquéllas, pero en las provincias llamadas de los Llanos se solían admitir mujeres y más aún cuando se hallasen casadas. Sostenía Solórzano que esta costumbre se debía observar donde se probase y estuviese acompañada de actos que la hayan introducido, porque "no lo hallamos falta de ejemplares de cargos, oficios y dignidades de mucho mayor porte en que suceden hembras...."33

Solórzano también utilizaba la voz ejemplar para designar las decisiones judiciales, ${ }^{34}$ en cuanto servían para invocarse en pro o en contra de determinada opinión.

A mi juicio, el ejemplar adquiere en nuestro autor su mayor expresión cuando lo utiliza en la configuración de una institución. En estos casos se hace visible la influencia de los doctores del Derecho común. El caso sobresaliente es el de las encomiendas, asunto desplegado a través del extenso libro tercero, uno de los más importantes de la Política Indiana. Allí brilla con luz propia el ejemplar de los feudos, "de cuyo ejemplo tanto nos valemos...,"35 $\mathrm{y}$ con decreciente intensidad el del mayorazgo, el del usufructo, etc. En otras partes de la obra también utilizaba el ejemplar de los beneficios, de las prebendas, de las capellanías, etc. Se trata de una fina elaboración intelectual destinada a construir la doctrina del nuevo instituto sobre la base de ejemplares o modelos que se examinaban y aplicaban según las materias y casos, pero siempre preservando la naturaleza de la figura indiana. Con un pronunciado acercamiento a técnicas dogmáticas, estamos en presencia de un matiz diferente del ejemplar. También se observa dentro de este modo la utilización de la voz para referirse a determinada estructura institucional concreta - como virreyes de Nápoles, Consejos de Aragón, Italia o Portugal, Contaduría Mayor de Cuentas de Castilla, etc. - aplicada a apoyar una opinión o decision. ${ }^{36}$

Cabe, por último, agregar que si bien era lo más frecuente que el ejemplar fuera invocado en apoyo de una afirmación, a veces se le traía para, una vez examinado, rechazar su aplicación en la situación concreta que se trataba.

33 Ídem, II, XXVII, 22.

34 Ídem, III, XX, 27-28; IV, XIV, 18; y IV, XXVI, 65.

35 Ídem, III, XIX, 12.

36 Ídem, V, XII, 56; V, XV, 17; y VI, XVI, 31. 
Una nueva evidencia del papel que necesariamente cumplía en el despliegue del discurso jurídico.

Destacada presencia y variados matices son rasgos que se perciben en la obra solorciana en punto a nuestra noción que aparecía así peraltada en el tejido de la creación jurídica.

\section{Uso e invocación en el despacho del Gobierno Supremo}

Contrariamente a lo observado en la Política Indiana, en los despachos de los órganos superiores de la Monarquía, la voz se aplicaba unívocamente a lo resuelto en otras ocasiones ante casos análogos. Para esta comprobación me he servido hasta 1630 de las consultas del Consejo de Indias, Cámara y Junta de Guerra coleccionadas por Antonia Heredia, donde alcanza mayor relieve la respuesta real, que se transcribe textualmente. Para el período posterior ha sido determinante el material que he cosechado en el Archivo General de Indias. En estos materiales he podido constatar mejor la actividad del propio Consejo y Cámara, de los fiscales y la Contaduría, así como otros interesantes aspectos del trámite de los negocios. En cambio, escasean las respuestas reales. La información reunida no es exhaustiva ni ha sido el resultado de una labor previamente diseñada. No obstante, estimo que puede considerarse representativa de la actividad burocrática durante un largo período que abarca desde el último tercio del siglo XVI hasta fines del XVIII. Hacia el último cuarto del Seiscientos se percibe el momento de mayor esplendor de este modo de creación jurídica, que se prolonga durante la siguiente centuria.

El uso de la voz ejemplar sólo se afirmó desde mediados del XVII, pues con anterioridad aparecía predominante en las respuestas reales el vocablo "consecuencia". Esto explica que fuese esta voz la que se encuentra en compilaciones impresas, como la de 1658, y en la propia Recopilación de 1680. En estos casos, los textos recogidos pertenecían a la primera mitad de la centuria.

1. La búsqueda de ejemplares, una tarea burocrática

En la última época se desplegó una técnica burocrática que puso su acento en la búsqueda del antecedente como elemento necesario para alcanzar la adecuada decisión del caso presentado. Disponemos de un precioso testimo- 
nio de 1714, que permite observar de cerca el trámite de los asuntos en el Consejo. Se trata del informe del fiscal Josef Agustín de los Ríos, que el Consejo hizo suyo y elevó al rey. ${ }^{37}$

Cuando llegan los papeles al Consejo - decía - y una vez hecha la separación si "se ofrece alguna especial materia y el Señor Secretario la participa entre todos sus oficiales cada uno le participa los expedientes, órdenes y providencias antiguas o modernas que sobre la referida materia se han ido dando o están pendientes, y este es un esencialísimo punto, por que sin él se volverá a las mismas antecedentes confusiones, y cada día se encontrarán las resoluciones". Y proseguía: si los papeles son sobre materia nueva se llevan al Consejo "pero si sobre la misma materia en otros tiempos, $\mathrm{u}$ ocasiones ha habido expedientes de aquella misma calidad en aquel Reino, Provincia o Ciudad se le agregan a los últimos que se reciben todos los concernientes a la dicha materia tanto de tiempos antiguos como modernos y para esto se pone un acordado al nuevo expediente en que se dice al fiscal con antecedentes, o tráigase al Consejo con antecedentes".

Más adelante, al abundar sobre la necesidad de conocer esa trama anterior sobre negocios análogos, agregaba: "En esto que tanto importa consiste el universal gobierno de todas las Indias, y en evitar cuanto sea posible la contrariedad de las resoluciones y providencias en una misma especie de negocios; salvo si la diversidad de las Provincias, su estado y reglas del mejor gobierno, no repugnan el que las reglas que se practican en unas, se observen en las otras".

Todas las materias que se despachan - continuaba el fiscal de los Ríos - no quedan acabadas "ni pueden quedar los expedientes arrinconados, ni arrimados porque incesantemente es menester volver sobre ellos, y valerse de ellos unas veces para la misma materia que ocurre de nuevo, y en vista de las resultas y cédulas que se han enviado a Indias porque a los pliegos o autos que hoy llevan es menester agregarlo todo lo que ha precedido"; y otras veces "para que sirvan de ejemplar si conviene para la determinación de otros expedientes de aquella misma calidad en aquel Reino, o en otro, o en aquella Ciudad o Provincias, o en otras, y en suma todo absolutamente cuanto se vé

37 Informe del fiscal D. Josef Agustín de los Ríos, incluido dentro de la representación del Consejo de Indias al rey, Madrid 26 de febrero de 1714 (Biblioteca de Palacio, Madrid, mss. 844). 
y despacha en dicha sala de gobierno queda siempre abierto para valerse de ello, con lo que cada día nuevamente ocurre...”.

Estos párrafos del informe del fiscal permiten puntualizar que en torno del ejemplar o antecedentes se desenvolvía esa práctica burocrática que conducía a la decisión final de cada negocio. Pero cabe apuntar que no se concedía a dicho antecedente un valor absoluto sino que, conforme a la mentalidad casuista, el propio caso merecía una consideración particular en atención a su peculiaridad.

Otro interesante testimonio del año siguiente confirma el anterior aunque revela una realidad algo diferente a la descripta por de los Ríos. En efecto, el 9 de septiembre de 1715 los dos secretarios del Consejo hicieron presente la necesidad de contar con oficiales para el arreglo y composición de los archivos del Consejo de ambas secretarías. Los mismos - decían - están de tiempo atrás "en tal confusión que ni se encuentra papel que se busca, ni se duda paran en ellos todos los que demas de 70 años a esta parte, se han causado consistiendo esto, en que de las repetidas mudanzas de Secretarios se han desatado muchos legajos y se han vuelto a juntar sin orden ni formalidad...”. Estimaban necesario no sólo que los archivos "se reglen y compongan, sino el que se formen índices de negocios y expedientes con separación de audiencias, para que el Consejo pueda ser servido con la puntualidad y claridad que se debe, en lo que manda se busque y haga presente, y para que los oficiales no dejen en el olvido muchos expedientes graves, que por no encontrar sus antecedentes y conocer que sin ellos no pueden ir al Consejo, se han quedado sin curso, en grave perjuicio del servicio del Rey y del bien público". El Consejo proveyó de conformidad al pedido de destinar dos oficiales para el arreglo de dichos archivos. ${ }^{\mathbf{3 8}}$

Este documento refuerza al primero en cuanto destaca el valor asignado a los antecedentes, a tal punto que consigna la detención de algunos expedientes porque los oficiales no los encontraban en el archivo desordenado. Lo contradice, en cambio, en cuanto revela un estado de desarreglo en los papeles que no permitía cumplir con el trámite que daba por asentado el fiscal de los Ríos. Alguno de los dos exageraba. Al fin el Consejo proveyó los oficiales solicitados. Al tiempo que reconocía ese desarreglo, quedaba otra vez en evidencia la importancia concedida a esa fase del trámite burocrático. 
Años después se volvía sobre la cuestión. En 1748 el secretario de Nueva España proponía al Consejo el nombramiento de un archivero, expresando que "la copiosa cantidad de libros y Papeles que contiene, se hallan casi inutilizados y es dificultosísimo el encontrar los antecedentes y ejemplares que cada día se necesitan tener presentes para el más seguro y mejor fundado expediente de los asuntos que se tratan en el Consejo...." ${ }^{39}$ Lo cierto es que pese a las dificultades mencionadas, quien trabaje sobre los papeles del Consejo en el siglo XVIII se encuentra con frecuencia agregados antecedentes a las cuestiones varias en trámite. ${ }^{40}$

La práctica de hacer buscar y traer al despacho los ejemplares está documentada durante el amplio período que abarca este estudio. En respuestas reales del XVI ya encontramos que se le preguntaba al Consejo lo que se había acostumbrado hacer en anteriores situaciones semejantes. ${ }^{\mathbf{4 1}} \mathrm{A}$ principios de la siguiente centuria se hallan frecuentes respuestas, tales como "avíseseme si se ha hecho otras veces" "avíseseme si se ha hecho con otros", "hágase lo que se hubiese hecho con otros", "avíseseme lo que ha acostumbrado con otras viudas de consejeros de este Consejo", etc., ${ }^{42}$ que claramente revelan el interés del rey por conocer esos antecedentes antes de estampar su decisión final a la consulta del Consejo.

En los años siguientes, conforme empezó a aparecer más a menudo la voz ejemplar, se lee en algunas de esas respuestas: "El Consejo diga si hay ejemplares..." "traigánseme todos los ejemplares que ha habido en esto...," etc. ${ }^{43}$ El propio Consejo en 1640 recurría a los ejemplares para saber si cierta decisión debía ser o no objeto de consulta al rey. ${ }^{44}$ Después de esa fecha se hizo frecuente que el Consejo, la Cámara y la propia Junta de Guerra requiriesen los ejemplares que hubiesen sobre casos análogos a los que debían resolver. También se advierte una más estrecha relación entre los ejemplares y la decisión, según se comprueba en algunos casos que examinaré en el punto siguiente. En ciertas peticiones, los ejemplares ya se acompañaban desde el momento de la presentación. Además se observa la práctica de acudir a "los

39 Íbidem.

40 Así lo observo, por ejemplo, en AGI, Indiferente General, 885.

41 Heredia, I (1529-1591), núms. 1054; y 1600-1604, núm. 244.

42 Ídem, 1600-1604, núms. 1400, 2022 y 1702; 1610-1616, núm. 1029.

43 Ídem, 1617-1625, núms. 1783 y 1929.

44 AGI, Indiferente General, 880. 
exemplares más favorables" cuando interviniese "en su breve despacho causa pública y el servicio de V. M....” ${ }^{45}$

En el trámite interno se observa que cuando la secretaría requerida carecía de ejemplares, se solicitaba la colaboración de la otra secretaría ${ }^{46}$ y de la Contaduría en la búsqueda de esos ejemplares que, por momentos y en determinadas materias, parecen desempeñar un papel decisivo en la resolución del negocio.

Esta tarea no declinó aun en los tiempos en que surgieron voces críticas contra su utilización. Sobre la expiración del siglo - en diciembre de 1799 anotamos que, ante una propuesta del gobernador del Consejo de Indias, marqués de Bajamar, sobre "el método y reglas" para repartir por turno y antigüedad entre los ministros togados del Tribunal determinados expedientes, el rey resolvió que se guardase una resolución anterior y por las secretarías se reuniesen "los antecedentes que hubiere para evitar la contradicción o variedad de providencias". ${ }^{47}$

\section{La fuerza jurídica del ejemplar}

En el momento de adoptar la decisión - o de aconsejarla - ¿qué fuerza ostentaba el ejemplar para inclinar esa resolución? Desde luego hemos advertido en el punto anterior el interés con que se buscaban, dentro de la labor burocrática, esos ejemplares. Esto mostraría ya un primer grado de influjo sobre la decisión. Pero es necesario avanzar algo más, observando, si es posible, en qué medida esos ejemplares fundaban las nuevas resoluciones y comprometían de antemano una solución ajustada a aquellos. Para ello veamos dos series de casos bien diferentes, ambas en el sentido de apoyar esa fuerza jurídica ostentada por el ejemplar.

\section{a) Fundamento de la decisión}

La primera serie permite observar cómo los ejemplares asumían el carácter de fundamento de la decisión real. Así se registran en lacónicas respuestas

45 Consulta del Consejo de Indias de 7 de septiembre de 1651, aprobada por el rey (AGI, Charcas 3).

46 Así se hizo ante una solicitud del Conde de Canillas en 1701 (AGI, Lima 407).

47 AGI, Indiferente General, 886. 
reales, sobre todo en la primera mitad del siglo XVII, estas elocuentes expresiones: "si es cosa que se ha hecho siempre se haga", 48 "siendo cosa ordinaria se haga"; 49 "hágase como parece pues se ha hecho con otros"; ${ }^{50}$ se haga lo propuesto "con que no exceda de lo que en otras ocasiones semejantes a ésta se ha hecho por lo pasado...." 51 No puede omitirse, en fin, otra frecuente expresión con aires consuetudinarios: "Hágase lo que se acostumbra en semejantes ocasiones". 52

El empleo de la voz ejemplar en el sentido indicado se advierte más nítidamente en decisiones del Consejo de Indias, de la Cámara y en dictámenes fiscales de los siglos XVII y XVIII. Del Consejo pueden citarse decisiones como éstas: "ajustándose a los ejemplares que se trae corra y no de otra manera", 53 "Corra este nombramiento atento a la aprobación del sujeto y los ejemplares que alega". ${ }^{54}$ De la Cámara: se dé la cédula de recomendación "si hay ejemplares de haberse dado a los eclesiásticos", 55 "hágase lo que con otros cuyos ejemplares se refieren", ${ }^{56}$ consúltese al rey "diciendo los ejemplares" ${ }^{57}$

Hay un caso que ilustra, por sí solo, acerca del peso que se le reconocía al ejemplar en el momento de la decisión. Se trata del planteo que en 1685 hizo, ante el rey, Nicolás Antonio de Lorenzana Ziaño. Era él parte de un pleito que se encontraba en la instancia de revista en la Casa de Contratación y solicitaba que para garantizar un fallo imparcial se asociara a los jueces de la Audiencia de Contratación con otros de la Audiencia de Sevilla, pues temía que el influjo de su contrincante don Baltasar Fernández Moreno, "persona de gran autoridad y con mano en todos los ministros de la Casa" - según decía - ablándase la voluntad de aquellos jueces. El Fiscal, en actitud favorable a la petición, sostuvo que aunque no había podido "adquirir noticia que haya ejemplar de que hayan pasado jueces de la audiencia a la Casa”, esto sí ocurría entre Jueces de los Consejos. Sin embargo, el Consejo de Indias

48 Heredia, 1617-1625, núm. 1502.

49 Ídem, núm. 1795.

50 Ídem, 1610-1616, núm. 1393.

51 Ídem, 1617-1625, núm. 736.

52 Ídem, 1626-1630, núm. 378.

53 AGI, Lima 25 (Año 1654).

54 Ídem, Indiferente General, 1496 (Año 1685).

55 Ídem, Indiferente General, 1484 (Año 1651).

56 Ídem, Lima 26 (Año 1670).

57 Ídem, Indiferente General, 1484 (Año 1653). 
consideró que la petición de jueces asociados era "una novedad no vista ni practicada", siendo suficiente encargar al Presidente de la Casa su presencia en la vista y votación del pleito. Disconforme con esta solución, Lorenzana insistió en la solicitud y percibiendo la importancia de valerse en su apoyo de algún ejemplar, invocó uno, que una vez verificado no resultó tal. Lo que interesa subrayar aquí es que bastó la invocación de la existencia del ejemplar para que el Consejo suspendiese la consulta ya acordada y requiriese a la Secretaría el reconocimiento de dicho ejemplar. ${ }^{58}$

En algunas materias, el ejemplar aparece como requisito que acompañaba la petición. Así lo he observado, desde fines del XVII, en diversas solicitudes de mercedes de viudas de ministros y oficiales del Consejo y de la Contaduría, despachadas en conformidad a dichos precedentes. ${ }^{59}$ Este carácter referencial no lo pierde aún cuando las circunstancias de cada caso modificasen la decisión. En una ocasión, la Cámara, luego de analizar los ejemplares de mercedes existentes y comparar las otorgadas a las viudas de ministros y contadores del Consejo, propuso una reducción para el caso, ${ }^{\mathbf{6 0}}$ iniciándose con este ejemplar una nueva práctica. ${ }^{\mathbf{6 1}}$ En otra oportunidad, luego de desechar tres ejemplares por no ajustarse al caso planteado, se adoptó una solución de equidad. ${ }^{62}$

Lo cierto es que, como decía el Fiscal con aprobación del Consejo en 1751 , la decisión contenida en los ejemplares "podrá y deberá servir de regla" para los casos que son de "la misma naturaleza y circunstancias que los que han precedido...." ${ }^{63}$ Esta convicción sobre el valor atribuido al ejemplar se encuentra también en la pluma de un peticionante, quien en 1668 al fundar su derecho, sostenía que "además de ser justicia le asiste la consecuencia" de haberse concedido lo mismo a otra persona. ${ }^{64}$

58 Ídem, Indiferente General, 1496.

59 Véase el ejemplo de la viuda de Joseph de la Cuesta, oficial de la Secretaría del Perú en 1685 (AGI, Indiferente General, 1496) y otros en 1689 (ídem, 1497).

60 Se trata de la petición de la viuda del Contador de Cuentas del Consejo, don Fernando García de Buitrago (1683) (AGI, Indiferente General, 1497).

61 Petición de doña Margarita de Vargas, viuda de Salinas en 1684 (AGI, Indiferente General, 1496).

62 Petición de doña Ana María de Quevedo y Mendoza, viuda de don Mateo del Castillo y Peralta (AGI, Indiferente General, 1497).

63 AGI, Lima 444.

64 Ídem, Lima 26. 
Desde otro ángulo se aprecia que la falta de ejemplares dio motivo al Fiscal del Consejo en una oportunidad para consolidar su dictamen contrario a la confirmación de una encomienda ${ }^{65}$ y en otra para solicitar - ante el doble vacío de leyes y ejemplares - que se diera "regla por donde se gobierne la materia en lo sucesivo" "66 Este último caso es buena muestra del valor concedido al ejemplar como fuente de derecho. Se trata de una duda acerca del procedimiento judicial en el Consulado de Lima. El Virrey y los oidores en Acuerdo dispusieron que siendo un caso nuevo para el cual no había precepto legal ni existía ejemplar, era preciso dar "regla para adelante". El Fiscal y el Consejo coincidieron en esta apreciación que se planteó en la consulta al rey y en la cual aparecía peraltado el ejemplar como una de las vías a las que acudía el jurista o ministro para la decisión de los negocios. Esto ocurría en 1757. Por último, cabe señalar que en una oportunidad la expresa anotación de que "no hay ejemplar" sirvió en 1777 para negar una petición de retiro militar con sueldo. ${ }^{67}$

\section{b) El temor a su consecuencia}

La segunda secuencia de casos nos lleva a destacar el peso jurídico que tenía el ejemplar, aunque el ángulo de visión sea distinto y casi opuesto al anterior. Se trata de observar la cautela desplegada en ciertas ocasiones para evitar que la decisión a adoptar se convirtiera en regla que comprometiera la solución de otras situaciones análogas en el futuro. Así es frecuente hallar en reales cédulas y otros despachos expresiones tales como: "que no sirva de ejemplar", que "no conviene introducir una consecuencia", que "se excuse por las consecuencias”. Cuando en 1604 una ya recordada respuesta real expresaba que "se sabe cuánto pueden los ejemplares", estaba mostrando, mediante el temor a las consecuencias, la fuerza jurídica que se reconocía a los ejemplares.

Acudamos a textos de diferentes épocas, contestes en exteriorizar la cautela. Atiéndase a estas respuestas reales a consultas del Consejo en el siglo XVI: "Esto parece cosa de consecuencia y que otros podrían venir a pedirlo por la misma causa y así es mejor excusar lo que se me consultó, ${ }^{68}$ "hágase

65 Ídem, Lima 443.

66 Ídem, Lima 419.

67 Ídem, Indiferente General, 1501.

68 Heredia, I (1529-1591), núm. 258. 
así, mirando en que no sea consecuencia para otros", ${ }^{69}$ "véase si esto será de consecuencia para otros" ${ }^{70}$ En una ocasión se negó una merced "por evitar la consecuencia que podría ser dañosa. ${ }^{71}$ En otra se dispuso recoger una real cédula anterior dados "los malos ejemplares que puede producir la gracia hecha...."72 Sobre recompensas y aumento de salarios se recomienda mucho la forma de hacerlo para no provocar "consecuencia". ${ }^{73}$ En cierto caso, aun cuando se admitió la justicia de la solicitud, el temor de constituir ejemplar llevó al rey a proponer otra solución compensatoria. ${ }^{74}$ Igualmente, en un caso de perdón al marido que mató a quien cometió adulterio con su mujer, el Consejo de Indias, en 1638, propuso suspender el indulto para evitar "la consecuencia y ejemplar que de su ejecución resultaría." ${ }^{75}$ En fin, se hizo frecuente que determinadas decisiones se adoptasen bajo la resolución de que no sirviesen de ejemplar para otras. ${ }^{76}$

\section{Materias en que se invocaba}

El holgado centenar de casos reunidos no me parece suficiente para establecer una sólida clasificación pero sí para adelantar una apreciación provisional. El ejemplar era invocado en una gran variedad de materias, con situaciones de diversa índole, al punto que la mitad de los casos pueden tener rubro propio. No he encontrado, salvo un caso del XVIII, el intento de reducir su invocación a determinadas materias o de excluir alguna.

De los casos agrupados, un $30 \%$ corresponde a mercedes otorgadas a viudas - y también a hijos - de ministros, oidores, oficiales y otros servidores de la Corona; casi un $20 \%$ se refieren a ayuda de costas, rentas o retribuciones extraordinarias a ministros, oficiales, obispos, indios, principales, incluyendo jubilaciones o retiros; un $12 \%$ a cuestiones de salarios, sobre todo lo relativo al aumento de los mismos y a su pago a virreyes y ministros

69 Ídem, 682 y 1355.

70 Ídem, II (1592-1598), núm. 2431.

71 Ídem, I (1529-1591), núm. 1853.

72 Real cédula de 17 de abril de 1687 al Virrey del Perú (AGI, Lima 587, lib. 29, fs. 317 v. $318)$.

73 Heredia, II, (1592-1598), núms. 2030, 2249, 2956, 3516 y 3582.

74 AGI, Indiferente General, 1293.

75 AGI, Charcas 2 (núm. 295).

76 Así en 1669 (AGI, Lima 26), 1684 y 1688 (ídem, Indiferente General, 1496 y 1497). 
durante el viaje a las Indias; menos del $10 \%$ comprenden asuntos eclesiásticos; y entre el 4 y $6 \%$ cada una de las cuestiones referentes a los oficios y funcionamiento del Consejo, licencias a oidores para casarse, beneficiar minas y obtener plazas en el distrito del que eran naturales, y a mercedes de encomiendas. El resto se reparte en cuestiones diversas. Como se advierte, hay abrumadora mayoría de cuestiones vinculadas a la atención de gastos y retribuciones de los servidores de la Corona, que supera el $60 \%$ de los casos registrados.

\section{4. ¿Cuántos eran necesarios?}

El examen de los casos arroja resultados a primera vista desconcertantes en cuando al número de ejemplares necesarios para alcanzar fuerza jurídica. Así se observa que la invocación de un solo ejemplar tuvo, en alguna ocasión, tanta fuerza que el Consejo suspendió la consulta ya acordada, a la espera de su reconocimiento. Por contraposición, la constancia de un solo ejemplar acompañando la petición fue motivo, en otra oportunidad, para que el fiscal la desechase. En medio de ambos extremos se constata que varios negocios eran resueltos conforme a un único ejemplar.

La tendencia general era buscar dos o tres ejemplares. Este último número parece el más corriente en la práctica burocrática. El Fiscal en 1751 dictaminó - con la aprobación del Consejo - basándose en esta cantidad de ejemplares que "la uniforme determinación, que se ha servido tomar S.M. sobre dichas instancias, podrá y deberá servir de regla para el caso presente, que es de la misma naturaleza y circunstancias que los que han precedido y se han visto y ven practicar en la misma Audiencia de Lima, sin que haya necesidad de referir otros muchos...."77 No obstante, en una ocasión los tres ejemplares que apoyaban la petición no impidieron que la Cámara modificase la regla que surgía de los mismos. Otras veces, era el último ejemplar, de los varios alegados, el que predominaba. Sólo de modo excepcional, en una oportunidad, se reunieron 14 ejemplares para comprobar una "práctica", que el Consejo acordó respetar, pese a ser otra la opinión fiscal. ${ }^{78}$

De acuerdo con lo expuesto, no puede determinarse el número exacto de ejemplares, con los cuales se podía imponer una solución. Esto confirma el

77 Petición del oidor don Pedro Bravo de Castillo (AGI, Lima 444).

78 Petición de don Francisco Lloaga en 1773 (AGI, Indiferente General, 919). 
carácter de apoyo que revestía este modo de creación jurídica, como también ocurría con los demás. El ejemplar concurría a enriquecer la deliberación, a inspirar la decisión, poseía una cierta fuerza pero predominaban las circunstancias del caso y el juicio prudente del ministro que, llegaban a veces, a doblegar la fuerza del precedente.

\section{Hacia el desplazamiento del ejemplar}

El ejemplar siguió la suerte de las otras fuentes del Derecho, con excepción de la ley. Su presencia se hizo notoria dentro de una concepción del Derecho que colocaba su atención en la resolución de los casos y se nutría de una normativa abierta y plural, dada por leyes, costumbres, opiniones de los autores, decisiones judiciales, etc. La ley no tenía entonces rol excluyente en la creación jurídica.

La situación se fue alterando paulatinamente a favor de la primacía de la ley, entendida ya de modo restrictivo como toda norma escrita dada por el rey o las autoridades que lo representaban. Tanto el aparato estatal en crecimiento - que se valió de la ley como principal instrumento de su acción -, como el pujante racionalismo - que aspiraba a dar reglas generales y universales a la sociedad - fueron factores determinantes que empujaron ya desde el siglo XVI a favor de la hegemonía de la ley, para llegar dos centurias después a postular el desplazamiento de los demás modos de creación jurídica. La costumbre y la doctrina de los autores fueron así objeto de las más conocidas críticas, intensas y por momentos virulentas. ${ }^{79}$ Dentro de esta crítica cabe también incluir al ejemplar, aunque se puede observar que no alcanzó la misma intensidad que la dirigida a las fuentes anteriormente mencionadas.

Ya en el siglo XVI podemos encontrar las primeras exteriorizaciones de tendencia crítica, pues como dice Maravall "frente a los exempla y a las autoridades de la doctrina medieval del saber, se colocaban la matemática y la razón”. ${ }^{\mathbf{8 0}}$ Tiempo después, Saavedra Fajardo advertía sobre "el peligro de

79 Sobre esto, pueden verse mis trabajos "La costumbre jurídica en la América Española (siglos XVI-XVIII)”, en Revista de Historia del Derecho, núm. 14, 1986, pp. 368 y ss., reproducido en El poder de la costumbre, cit., pp. 97 y ss., y "La doctrina de los autores..., cit., pp. 382 yss.

80 José Antonio Maravall, "El concepto del Renacimiento como época histórica”, en ídem, Estudios de Historia del Pensamiento Español, $2^{\text {a }}$ serie, Madrid, pp. 68-69. 
gobernarse el príncipe por ejemplos, siendo muy dificultoso, cuanto no imposible, que en un caso concurran igualmente las mismas circunstancias y accidentes que en otro". Agregaba que ".los casos de otros sean adverti-

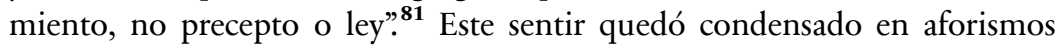
como éste: "Los pareceres de los hombres son dudosos, las circunstancias de las cosas variables; y por eso mal seguro los ejemplos". ${ }^{82}$ La misma ley indiana de la Recopilación de 1680 era, como se recordará, bastante cauta en admitir la fuerza de los ejemplares.

Esta tendencia se ahondó en el siglo XVIII. En 1723 un autor insistía en afirmar que "juzgar por ejemplares, es peligroso, porque aunque haya sucesos que se parezcan mucho, basta que no sean los mismos, o que el tiempo sea otro, para que necesite el juicio prudente de variar, según las circunstancias" ${ }^{83}$

Bajo otro clima intelectual, más favorable al legalismo, se desplegaba en 1765 la crítica de Juan Francisco de Castro. Racionalista que sólo depositaba su confianza en la ley, este autor aspiraba a que se elaborase un cuerpo legal sistemático. En sus páginas contra la costumbre y la opinión de los autores también incluía a las decisiones de los tribunales en cuanto pudiesen servir de ejemplares para resolver casos futuros. Aun cuando su juicio se centraba en esta especie de ejemplares - creados por decisiones de los jueces - resultaba extensivo a las demás especies. Castro se empeñaba en manifestar ya una división entre los antiguos doctores en punto a la valoración de esta fuente: "Algunos doctores dan a las decisiones de los tribunales superiores una virtud poco inferior a la de la ley para que sirva de regla en semejantes casos. Desconocen otros esta superior virtud en las decisiones, reconociéndola solo en la razón en que se fundan, afirmando severamente no deber juzgarse por ejemplares sino por las leyes". El autor se enrolaba en esta segunda corriente empeñado en mostrar la "inconstancia, incertidumbre e irracionalidad" cuando no deformidad - que se encerraba en esas decisiones "para que no puedan servir de ejemplares que indistintamente se deban imitar". ${ }^{\mathbf{4}}$

81 Diego de Saavedra Fajardo, Idea de un príncipe político-cristiano, empresa XXIX (Biblioteca de Autores Españoles, t. 25, pp. 76-77).

82 Setanti, Centellas..., cit., núm. 72.

83 Francisco Antonio de Castro, Dios y Mundo. Teatro cristiano y político para la idea de un perfecto cortesano, Madrid, 1723, p. 216.

84 Juan Francisco de Castro, Discursos críticos sobre las leyes y sus intérpretes... (1765). Edición utilizada, Madrid, 1829, t. I, pp. 252 y 254-256. 
Quien conozca el tono en que se desplegaba por entonces la crítica contra algunas fuentes del Derecho - especialmente la denominada "ideología antijurisprudencial" ${ }^{85}$-, advertirá que la virulencia e intensidad era mucho menor tratándose de los ejemplares. ¿Se la consideraba de menor importancia o acudían otras razones?

Según he constatado en los papeles del Consejo, hasta fines del siglo XVIII los ejemplares seguían siendo invocados en el despacho del gobierno supremo. Sin embargo, dos testimonios de la época llevan a verificar una posible retracción en su uso, frente a la ley. Cuando en el Consejo se trató acerca del pase de un rescripto del Papa designando por sí al Obispo de Cuba Asistente al Solio Pontificio, se invocaron ejemplares que no se pudieron encontrar, resolviéndose finalmente retener dicho rescripto. Pues bien, en unas reflexiones agregadas a la pertinente consulta se expresaba que este caso debía juzgarse por las leyes y no por los ejemplares. Estos últimos - continuaba sólo obraban en materia de precedencias, ceremonias y cortesías, sirviendo sólo en lo demás "para abreviar en las idénticas juzgando por lo resuelto." ${ }^{\mathbf{6}}$ El segundo testimonio corresponde a un planteo efectuado por la Secretaría del Perú contra la Escribanía de Cámara por considerar que ésta se injería en negocios que le competían a aquella. Sostenía ante el Consejo que le correspondía la concesión de auxiliatoria de cualquier despacho mientras no se formase litis, pudiendo esto acreditarlo con muchos ejemplares pero - agregaba - se omitía la presentación de los mismos en atención a que el Consejo "atiende siempre como corresponde, para sus sabias determinaciones las reglas de la razón y no de las de los ejemplares, mayormente cuando en la materia de que se trata, como la presente, hay clara y expresa legal disposición..." ${ }^{87}$ Son testimonios sugerentes, aunque no determinantes, en cuando se percibe una marcada idea sobre la superioridad de la ley y un desplazamiento del ejemplar. ¿Era éste un sentir generalizado entre los ministros del Consejo?

En fin, queda planteado como interrogante final cuál fue el grado efectivo de decaimiento sufrido por el ejemplar con el advenimiento del legalismo, que debilitó y hasta temporalmente aniquiló las restantes fuentes del dere-

85 Véase mi trabajo "La doctrina de los autores...", cit., pp. 382 y ss.

86 Manuel José de Ayala, Consultas y pareceres..., VIII, f. 105 (Biblioteca de Palacio, Madrid, núm. 2756).

87 AGI, Indiferente General, 860. 
cho. Mientras llegan nuevos estudios concretos, queda dominante la impresión de que el antecedente o precedente, que en todas las épocas nutrió el saber de juristas y políticos, ha tenido, bajo mil formas, presencia y valor, en cuanto condensa la experiencia de gobernar y juzgar e ilumina nuevas opiniones o soluciones. 



\section{La noción de Justicia en la Politica Indiana de Solórzano*}

Sumario: 1. Una notas incitativas - 2. La justicia en el texto solorciano - 3. Virtud social y fin político -4 . Justicia distributiva y conmutativa -5 . Proceso judicial y decisión final - a) Un proceso ajustado a formas jurídicas - b) Una decisión conforme a Derecho - c) Un sentido más abarcador -6 . El enlace entre acepciones

\section{Unas notas incitativas}

Mi interés por indagar sobre la noción de justicia en determinado autor no persigue un mero afán erudito, de exquisitez intelectual, que peralte una pura elaboración especulativa. Sin desdeñar este aspecto, mi propósito es, en esta ocasión, examinar el uso de la noción en la praxis jurídica. Así verificar hasta qué punto se recibe el influjo doctrinario, apreciar cómo opera dicha noción en la argumentación de los juristas, observar el valor que se le asigna dentro de la mentalidad entonces dominante. Para ello es preciso tener en cuenta que el pensar casuista, problemático en sí mismo, necesita contar con nociones y reglas que sirvan de apoyo en la elaboración de las soluciones particulares. ${ }^{1}$ La falta de preceptos rígidos dentro del ordenamiento llevaba a apreciar determinadas nociones, como la de justicia, la cual tuvo una función clave, actuando como guía, meta y límite, al mismo tiempo. El jurista casuista no intentaba una "disección filosófica" ni una crítica demoledora de esta noción, más bien procuraba preservarla dada su utilidad argumentativa.

La Política Indiana, como es sabido, es obra representativa del Derecho indiano. A mi juicio, la mayor de todas. Su elección no es, pues, arbitraria. Cuando me refiero a obra jurisprudencial lo hago bajo el supuesto de que la doctrina de los autores no fue sólo uno de los modos de creación jurídica de

* Publicado en Homenaje a Ismael Sánchez Bella. Coordinación: Joaquín Salcedo Izu, Universidad de Navarra, Pamplona, 1992, pp. 609-619.

1 Véase Víctor Tau Anzoátegui, Casuismo y Sistema. Indagación histórica sobre el espíritu del Derecho Indiano, Buenos Aires, 1992, pp. 452-458. 
la época sino que actuó como fuente directiva del ordenamiento - siempre que se acepten las conclusiones de un reciente estudio mío. ${ }^{2}$ En este sentido, la auctoritas de la Política Indiana es indisputable. Ella recogió, fijó y expandió - sin pretensión alguna de originalidad - esa noción de justicia, incorporándola a la mentalidad de los juristas durante un siglo y medio, período durante el cual estimativamente se prolongó la fuerza jurídica efectiva de dicha obra.

Percibo que estas notas son más incitativas que conclusivas, así tanto por la naturaleza de la cuestión tratada como por la cortedad del enfoque que estoy en condiciones de ofrecer. El tema es, en sí, de mucho alcance y hasta ahora los historiadores del Derecho han optado por dejarlo a cargo de otros estudiosos por considerarlo propio del pensar especulativo y ajeno al ejercicio cotidiano de los juristas. Es precisamente esto último lo que ahora intento rescatar, como paso necesario para conocer la forma de pensar y argumentar de los jurisconsultos indianos. Según decía Sebastián de Covarrubias, a principios del siglo XVII, la justicia era la sustancia y el nervio de los juristas y el objeto de su ciencia o arte. ${ }^{3}$ La expresión es muy significativa dado que recoge un sentir de la época.

\section{La justicia en el texto solorciano}

La noción de justicia, originada en la reflexión teológica y filosófica, se filtra y simplifica - cuando no deforma - al penetrar en la esfera de los letrados. Esto se observa en la Política Indiana. No encontramos allí definiciones precisas, ni desarrollos doctrinarios ni tratamientos exhaustivos en torno a esa noción. Sin embargo, la voz forma parte del vocabulario básico y escogido de Solórzano y se introducía con justeza en la argumentación, denotando una solidez conceptual proveniente de su formación intelectual. ${ }^{4} \mathrm{Su}$ utilización era sobria. No acudía Solórzano al mundo de las imágenes, plásticas o literarias, ni a las alegorías para hacer más penetrante su idea de la

2 "La doctrina de los autores como fuente del derecho castellano-indiano", en Revista de Historia del Derecho, núm. 17, Buenos Aires, 1989, pp. 351-408.

3 Sebastián de Covarrubias, Tesoro de la lengua castellana o española (1611), edición Barcelona, 1943, p. 724.

4 Sobre esto, F. Javier de Ayala, Ideas políticas de Juan de Solórzano, Sevilla, 1946, pp. 95 y ss. 
justicia como, por ejemplo, lo había hecho medio siglo atrás Castillo de Bobadilla. ${ }^{5}$ Tampoco utilizaba adjetivos o palabras ampulosas para rodear la noción, ni se percibe una exaltación intencionada o apologética. En ese sentido resulta aplicable el juicio de Pérez de Tudela cuando afirma que la Política Indiana es obra expresiva de "un peculiar pragmatismo jurídico, de base histórico-positiva, que representa, en este aspecto, como un polo opuesto del racionalismo jurídico de base teologal", más ceñido a una cosmovisión "romanista" y fiel al magisterio de los doctores del Derecho común. ${ }^{\mathbf{6}}$

La intención de Solórzano parece dirigida a materializar la justicia, dando importancia a su administración y conservación en la república. ${ }^{7}$ Se pueden registrar, a mi juicio, tres principales sentidos ${ }^{8}$ en la utilización de dicha voz: a) un uso genérico, que muestra a la justicia como virtud, como fundamento del orden social y como fin del reino o de la Monarquía; b) una acepción influida por la clasificación aristotélico-tomista, que distingue, en lo particular, la justicia en distributiva y conmutativa; y c) un uso concreto, para determinar el ámbito material donde se resuelven las controversias, dentro del aparato de poder público. Vamos a desplegar cada uno de estos tres sentidos en los puntos siguientes.

\section{Virtud social y fin político}

La justicia concebida como virtud general que abarca a todas las demás, es una idea que se mantiene desde la Antigüedad hasta nuestros días. Constituye el fundamento del orden social y para sustentarlo es precisa "la actuación ordenada y constante de los hombres". Como dice González Alonso, en el siglo XVI "los tratadistas entonan sin cesar salmodias a la justicia como la

5 Política para corregidores y señores de vasallos en tiempos de paz y de guerra (1597), edición utilizada, Madrid, 1775, lib. II, cap. II, III y IV.

6 Juan Pérez de Tudela y Bueso, "La Política Indiana y el político Solórzano (Aproximación a un tema jurídico desde la metodología del historiador general)", en Revista de Indias, núms. 123-124, Madrid, 1971, p. 94.

7 Ayala, Ideas..., cit., pp. 297 y ss.

8 Sobre acepciones diversas de la justicia, véase José Castan Tobeñas, La idea de justicia en la tradición filosófica del mundo occidental y en el pensamiento español, Madrid, 1946, pp. 7-14.

9 Alfonso García-Gallo, Manual de Historia del Derecho Español, Madrid, I, 1964, p. 164. 
primera y más sublime de las virtudes que deben adornar al príncipe cristiano". 10

En varios pasajes se detecta en la Política Indiana el uso de dicha voz en aquel sentido de virtud general. ${ }^{11}$ Así lo hacía Solórzano para fundar el origen mismo del poder de los reyes, ${ }^{\mathbf{1 2}}$ para establecer en lo que debían esmerarse los virreyes, ${ }^{\mathbf{1 3}}$ y en fin, para señalar la dificultad con que, dada la distancia, operaba la justicia en las provincias indianas. ${ }^{\mathbf{1 4}}$ Unida a otras virtudes - misericordia, piedad, caridad - la justicia servía para alcanzar soluciones más adecuadas en cada situación. ${ }^{15}$ Así instruía Solórzano a los alcaldes del crimen de las audiencias para que cuando hubiesen de sentenciar, juntasen "la justicia con la misericordia", procurando no mostrar odio ni rencor contra las personas de los delincuentes, sino castigar sus delitos, sin proceder arrebatadamente en la ejecución de penas corporales. ${ }^{\mathbf{1 6}}$

Solórzano no evidencia predilección por ocuparse de la justicia, como virtud igualadora. Esta idea ya la encontramos en Cicerón, quien la equiparaba con la aequitas. ${ }^{17}$ Las Partidas decían que la justicia era "raigada virtud que dura siempre en las voluntades de los omes justos, e da e comparte a cada uno su derecho igualmente". ${ }^{18}$ El mantener "igual justicia" con todos, humildes y poderosos, era un reclamo que Maravall encuentra en el siglo XVI, frente a otra tendencia que propugnaba darla en proporción al estado de cada uno. ${ }^{19}$ Solórzano sólo hacía escuetas referencias a esta cuestión, lo que no permite ahondar en su pensamiento. Expresión saliente al respecto es cuando establecía que en lo que debían esmerarse los virreyes era en que "se administre bien y con igualdad la justicia en las Audiencias y Provincias que tuviesen a su cargo", porque - agregaba - "esta virtud encierra en si las demás

10 Benjamín González Alonso, "La Justicia”, en Enciclopedia de Historia de España, II, Madrid, 1988, p. 378.

11 Véase la interpretación de Pérez de Tudela, “La Política...”, cit., p. 109.

12 Juan de Solórzano Pereira, Política indiana (1647). Edición utilizada, Madrid, 1776. Dedicatoria, núm. 19; y V, XII, 34.

13 Ídem, V, XII, 34.

14 Ídem, II, VII, 73; y V, XVI, 9.

15 Ídem, Dedicatoria, núm. 19; II, VII, 24; y V, VI, 27.

16 Ídem, V, VI, 27-29.

17 García- Gallo, Manual..., cit., p. 150; Castan Tobeñas, La idea..., cit., pp. 14 y ss.

18 Partidas, $3^{\mathrm{a}}, \mathrm{I}, 1$.

19 José A. Maravall, Estado moderno y mentalidad social. Siglos XV a XVII, Madrid, 1972, II, pp. 231 yss. 
y para que se consiga fueron criados los Reyes principalmente".20 A esto debe sumarse, sin duda, su conocida caracterización de las audiencias como "los castillos roqueros de [las Indias], donde se guarda justicia, los pobres hallan defensa de los agravios, y opresiones de los poderosos, y a cada uno se le dá lo que es suyo con derecho y verdad".

La voz justicia adquiría valor supremo cuando enlazada con Derecho era utilizada para expresar el punto culminante de un juicio. ${ }^{22}$ De la pluma de Solórzano brotaban expresiones como ésta: "ninguna cosa hay más conforme a justicia y derecho, que seguir lo que su Divina Majestad con su gran Ciencia y Providencia ordena y dispone...."23 En otro pasaje, refiriéndose a los títulos adquisitivos de las provincias indianas, marcaba a fuego "el derecho y justicia de nuestros Reyes y Señores". ${ }^{4}$

Para Solórzano, como para los juristas de su tiempo, la justicia era considerada como el fundamento del orden social. "Mantiene el mundo en paz y hace vivir al hombre cuerdamente", se leía en las Partidas. ${ }^{25}$ El jurista, consecuente con esta idea, elogiaba los Consejos y consejeros que atendían los negocios de los reinos que componían la Monarquía "con que los sustenta y conserva en justicia, paz y tranquilidad". ${ }^{26}$ Y poco más adelante, compartía la idea ajena de que los reinos con buenas leyes y buenos jueces "se conservan en paz y en justicia". ${ }^{27}$

\section{Justicia distributiva y conmutativa}

Ya entrando en el segundo de los sentidos indicados, cabe señalar que Solórzano utilizaba ocasionalmente - pero con la firmeza de arraigada convicción - la clásica y entonces prevaleciente clasificación aristotélico-tomista de jus-

20 Política Indiana, V, XII, 34. En las transcripciones de aquí en adelante destaco los vocablos y pasajes que interesan en este trabajo.

21 Ídem, V, III, 7.

22 Castan Tobeñas, La idea..., cit., pp. 61-63.

23 Política Indiana, I, IX, 8.

24 Ídem, I, IX, 3.

25 Partidas, $3^{\mathrm{a}}, \mathrm{I}, 2$.

26 Política Indiana, V, XV, 1.

27 Ídem, V, XVI, 3. Pérez de Tudela hace una particular interpretación de este párrafo, "La Política..., cit., p. 109. 
ticia conmutativa y distributiva, ${ }^{28}$ incluyendo dentro de la primera a la judicial. Así afirmaba que los virreyes debían "cuidar mucho" de la justicia distributiva, que "es la que corre por sola su mano". ${ }^{29}$ En fuerza de ella se había de atender a los méritos y servicios de los solicitantes en punto a la elección de los oficiales y a la concesión de las encomiendas. ${ }^{30}$ Agregaba, recogiendo la opinión de otro autor, que dar las encomiendas a los beneméritos era, no solo en virtud de la justicia distributiva, sino también de la conmutativa, ya que no era sólo premio "sino estipendio y satisfacción de sus grandes trabajos y sangre derramada en aquellas Provincias" ${ }^{31}$

La justicia conmutativa se administraba ordinariamente en causas civiles y criminales a cargo de las audiencias y otros ministros. ${ }^{32}$ No cabía al virrey intervenir directamente en la misma, pero como Presidente de la audiencia debía velar para que se administrase "con entereza y cuidado" ${ }^{33}$ Estaba presente en esta distinción la división que se hacia entonces entre negocios de gobierno y justicia.

\section{Proceso judicial y decisión final}

Es, sin duda, en la tercera acepción enunciada cuando la voz justicia adquiere carácter más concreto, al referirse al ámbito material de dar solución a las controversias dentro del aparato de poder. Este sentido, que entro a considerar, no puede ser abruptamente separado de los anteriores. Es más, sólo se explica y fundamenta teniéndolos en cuenta. Pero, a mi juicio, se levanta dominante sobre los otros en la visión solorciana, debido a que estamos en presencia de un jurista que opera sobre la práctica.

Este sentido aparece plasmado en aquellas expresiones "hagais justicia", "haréis justicia", "hagan justicia", que vemos utilizar en disposiciones reales y en otros escritos públicos y particulares. No era expresión nueva en los tiempos de Solórzano. Encerraba dos ideas que cabe examinar por separado.

28 Castan Tobeñas, La idea..., cit., pp. 20 ss. y 49; García- Gallo, Manual..., cit., p. 151; y Ricardo Zorraquín Becú, La función de justicia en el Derecho Indiano, Buenos Aires, 1948, pp. 20 y ss.

29 Política Indiana, V, XII, 34.

30 Ídem, V, XII, 39.

31 Ídem, III, III, 40; y III, VIII, 7-9.

32 Ídem, V, XII, 34.

33 Ídem, V, XIII, 20. 
Una, era la existencia de un proceso bajo formas jurídicas, garantías procesales y dirección de letrados; y otra era que, mediante el mismo, se arribase a una decisión conforme a Derecho, sobre la base de lo alegado y probado. Aquellas expresiones apuntaban, según las ocasiones, a una idea o a las dos.

a) Un proceso ajustado a formas jurídicas

Veamos, en primer lugar, al proceso judicial entendido "como camino o método imprescindible para la declaración de lo que es justicia” que quedó afirmado desde los siglos finales de la Edad Media, según lo muestra Maravall. ${ }^{34}$

El Derecho aparecía así vivo bajo la forma de un procedimiento monopolizado por el "aparato estatal" en ciernes y regido por ministros letrados. Esta idea estaba incrustada en la mentalidad del Barroco y se refleja nítidamente en Solórzano. Un párrafo saliente al respecto encontramos en el capítulo que trata sobre las audiencias. Bien vale su transcripción:

"Es cierto lo que voy diciendo, de que los Virreyes y Gobernadores no pueden, ni deben entrometerse en las cosas que conciernen a administración de justicia, sino que las han de dejar a las Reales Audiencias, en tanto grado, que aunque se les haya enviado, y dirigido a ellos alguna cédula, con cláusula: Que hagan justicia en el caso que en ella se refiere, se ha de entender por las vías, y formas legales, y excitando por su parte, como Presidentes que son de las mismas Audiencias, a los Oidores, o Alcaldes de ellas que administren la dicha justicia, y sin que por semejantes palabras se pueda, ni deba entender, que fue de la voluntad de su Majestad, ni de su Real Consejo que los Virreyes la administren por sí, o que innoven, ni alteren el estilo de cada tribunal, ni hagan juntas de unos Jueces con otros por solo su arbitrio, como expresamente está declarado en un capítulo de carta escrita a la Real Audiencia de Lima en tres de junio de 1620. Por la cual parece, que la Audiencia había dado cuenta que con el calor de estas cláusulas lo turbaban todo los Virreyes, y se lo abrogaban, y avocaban, y se le respondió: Que estas cédulas ordinariamente son excitativas, y se dan solo para que se haga justicia a las partes. Y mi intento no es mudar el ser del juzgado, ni el estado de la causa, lo cual se incluye

34 Maravall, Estado Moderno..., cit., II, pp. 430 y ss. También véase González Alonso, "La Justicia", cit., p. 380 . 
todo en la cláusula que manda se haga justicia. Estareis advertidos, para ir en todas ocasiones con este presupuesto, con lo cual se escusarán las dudas que referís". Agregaba Solórzano que esta cédula "se conforma con lo que en este punto está determinado por derecho común, como ya lo tengo tocado en otro capítulo (III, XXVI, 53) y lo prosiguen latamente Maranta, Giurba, Mandosio, Marta, Sarabia, Riccio, Valenzuela y otros Autores, concluyendo, que el intento de esta cláusula solo es excitar la jurisdicción, y que excitar la jurisdicción es lo mismo que conceder la ordinaria" ${ }^{35}$

Según se advierte, en este párrafo medular Solórzano enlazaba la determinación de los doctores del Derecho común con una precisa disposición indiana. Esta cédula de 1620 aparece como pieza clave y decisiva en el tema que venimos considerando no sólo por su certero contenido sino porque fue recogida en cedularios particulares ${ }^{\mathbf{3 6}}$ y desde luego enaltecida por su inclusión en la Política Indiana en la forma referida. ${ }^{37}$ El estímulo para su dictado estuvo dado por una cuestión que era frecuentemente reavivada y debatida: la intromisión de virreyes y gobernadores en la administración de justicia ${ }^{38} \mathrm{y}$ sobre todo la conflictiva delimitación entre los asuntos de gobierno y de justicia.

No era ajeno a esta cuestión el avance de las teorías y pretensiones absolutistas, que podía llegar a destruir principio tan asentado. Solórzano reparó en ello. Precisamente, en un voto particular como ministro del Consejo de Indias en 1642 sostenía el peligro de "proceder y castigar sin autos judiciales aun en los Príncipes absolutos cuando juzgan ex infallibili conscientia" ${ }^{39}$

Puede sospecharse, sin embargo, que la justicia, administrada conforme a un proceso bajo formas jurídicas, haya tenido más de una excepción, no sólo por ese "poderío absoluto" de los príncipes, sobre el cual alertaba Solórzano. Así se advierte, en ocasiones, una cierta contemplación hacia el desvalido que no podía aportar los papeles que acreditaban su derecho. Una interesante

35 Politica Indiana, V, III, 37-38. Con letra bastardilla destaco pasajes salientes del texto.

36 Como ejemplos, la he ubicado en "Provisiones reales para el gobierno de Indias" (Biblioteca Nacional de Madrid, mss. 2989, 1237); y en "Sumarios de cédulas y otras disposiciones relativas al Virreinato del Perú" (Biblioteca de Palacio, Madrid, mss. 1626).

37 El texto completo de esta real cédula en Archivo General de Indias (en adelante AGI), Lima 571, libro 18 , fs. 281-281 vta.

38 Exponente de esta situación es la real cédula de 16 de abril de 1618 (AGI, Lima 571, libro 18 , fs. 28v.-29).

39 AGI, Indiferente General, 880. 
muestra, desgraciadamente trunca, he hallado en un sugestivo dictamen del fiscal del Consejo de Indias ante el arribo a la Corte del limeño Francisco Lorenzo. Este indiano, en pos de justicia, alegaba que se le había despojado de una casa y dos estancias, una de carneros y otra de vacas. El fiscal expresaba entonces que "esta parte no comprueba nada de lo que dice por papeles pero su necesidad y pobreza y la distancia del camino aseguran la verosimilitud y certeza de lo que dice y puede ser muy de la piedad del Consejo darle cédula para que el Virrey del Perú oiga a este hombre y haga que se le guarde justicia y reconozca sus pretensiones y no de lugar a que por pobre peligre su derecho y de lo que obrare avise al Consejo" ${ }^{\mathbf{4 0}}$

No he encontrado resolución del Consejo al respecto, tal vez no la hubo. No obstante, es un buen texto para mostrar un tipo de justicia excepcional, para "pobres sin papeles". Cabe observar que la intención del fiscal era remitir el asunto al virrey y no a la audiencia ¿Se trataba de encaminarlo por la vía sumaria y de protección que ofrecía la senda virreinal? No lo sabemos, aunque así parezca. Sin pronunciarse sobre este tipo de justicia u otros análogos, ${ }^{41}$ lo cierto es que la inclinación de Solórzano era hacia la afirmación de un proceso escrito, con probanzas, defensas y alegatos.

\section{b) Una decisión conforme a Derecho}

En cuanto a la segunda idea, es decir, el complejo mundo de la decisión final que pone término al proceso, algunos textos de la Política Indiana permiten penetrar en la cuestión. En cierto pasaje, Solórzano puntualizaba que la más común y legal acepción e inteligencia de aquellas palabras "hagais justicia”, es la de excitar los ánimos de los jueces para que "breve y legítimamente, y por los términos y disposiciones del [Derecho] despachen semejantes negocios". Se trataba aquí de ahondar lo correspondiente a la decisión y de establecer en que debía apoyarse. Solórzano lo hacía al interpretar la real cédula de 30 de julio de 1568 relativa al cumplimiento de la voluntad testamentaria de los encomenderos de que por algún tiempo no se cobrasen tributos de sus indios en descargo de sus conciencias. Estimaba que esos términos eran muy duros contra los herederos, quienes no estaban obligados a cumplir tal voluntad,

40 AGI, Lima 25.

41 Sobre la complejidad que ofrecía la función de justicia en la España de la época, véase GonzÁlez Alonso, "La Justicia”, cit., pp. 382 y ss. 
apoyando su juicio precisamente en la cláusula de la cédula que encomendaba hacer "entero y breve cumplimiento de Justicia" ${ }^{\mathbf{2}}$

$\mathrm{Al}$ ocuparse de los fiscales, Solórzano recogía el consejo de Casiodoro autor de su predilección - en cuanto a que aquellos "no piensen que por defender el Príncipe le hacen servicio en procurar vencer los pleitos que le tocaren, con su potencia: porque para él no habrá cosa más gustosa y loable de que los pierda cuando no tuviere justicia, ${ }^{43}$ expresión que debe entenderse en el sentido de que no le asistía el Derecho, una vez oídas las partes y probadas las cuestiones suscitadas.

Cabría preguntarse, llegando a un perfil más agudo, cuáles eran los apoyos jurídicos que concurrían a establecer esa apetecida solución conforme a "justicia” ¿Eran sólo los libros de los jurisconsultos? ¿Debía también la decisión ajustarse a las leyes reales? No encuentro en Solórzano una respuesta taxativa a estos interrogantes, pero no parece aventurado sostener que, antes de separar ambas cuestiones, el jurista de la época tendía a unirlas. Aquella interpretación que Solórzano hacía de la real cédula de 1568 autoriza a suponerlo. Mucho más si recurrimos a tres ejemplos, uno de los cuales se recoge en la propia Política Indiana. Se trata de una real cédula dirigida, en 1622, a la Audiencia de Lima referente a que las renunciaciones de oficios debían hacerse en personas idóneas, en la cual se concluía expresando que "en todo guarden justicia y las leyes" ${ }^{\mathbf{4 4}}$ Unos años después el Consejo de Indias, dirigiéndose al Presidente de la Audiencia de Charcas con relación a posibles demandas contra el ex-visitador de aquella provincia, le encargaba que "haga justicia conforme a derecho y cédulas". ${ }^{45}$ Una nueva muestra, esta vez de mediados del siglo XVI corrobora la impresión recogida. Es la respuesta real dada a un oidor de la Audiencia de los Confines acerca de la aplicación en Indias de una ley castellana sobre el término de las apelaciones, donde se decía que "en lo que hubiere lugar se guarde en todo por ley y que donde hubiese impedimento haga justicia" ${ }^{46}$

42 Política Indiana, III, XXVII, 50, 52-53.

43 Ídem, V, VI, 4.

44 Ídem, VI, XIII, 31.

45 El Consejo de Indias al Presidente de la Audiencia de Charcas, acerca de demandas contra el visitador de Charcas, ya difunto, don Juan de Palacios, 10 de marzo de 1651 (AGI, Charcas 21).

46 Colección Somoza. Documentos para la Historia de Nicaragua, t. XI, Madrid, 1956, p. 468. 
No se trata de ejemplos solitarios. Abunda en la documentación el uso de estas expresiones, que los juristas de la época manejaban sin dificultad. Los citados son pues casos representativos. Según se advierte, en los mismos aparece - bajo distintos términos - esta idea medular: la justicia debía hacerse conforme al Derecho - léase saber de los doctores - y a las leyes, dadas por el poder real. Es más, la voz justicia aparecía como equivalente a saber jurisprudencial, al punto que en el segundo ejemplo, para evitar una repetición, se le sustituye por derecho. Un repaso sobre esas muestras selectivas evidencia que en las dos primeras prevalecía en la cita ese saber contenido en las obras jurisprudenciales y sólo en la última se inclinaba a dar preferencia a la ley.

La voz justicia, empleada en sentido análogo al que venimos observando, vuelve a lucir en otro pasaje de la Política Indiana, cuando refiriéndose en concreto a la precedencia del Consejo de Indias sobre el de Flandes, Solórzano afirmaba que, en algunas materias, ciertas "razones de Estado" muchas veces hacían que "se atropellen las que solo se fundan en rigurosa justicia." Es bien claro que aquí nuevamente la voz justicia se empleaba en el sentido de saber jurisprudencial, como Derecho estricto. En este orden es que Solórzano sostenía la precedencia que correspondía al Consejo de Indias, pero admitía que la existencia de "razones de Estado" podía dar otro giro a la decisión final.

A propósito de esta cuestión, es oportuno recordar que Solórzano sostenía que el juzgador jamás debía fallar "por solo su ingenio y capricho, apartándose de la escrita y bien cimentada y practicada jurispericia”. Bajo esta expresión se refería al vasto conjunto de leyes, costumbres, opiniones, decisiones, ejemplos, razones, etc. contenidos en las obras jurisprudenciales. ${ }^{48}$

\section{c) Un sentido más abarcador}

Si bien no dudo que algunos de los ejemplos que acabo de presentar puedan superar el alcance que le he asignado, traigo a colación otros ejemplos para

47 Política Indiana, V, XV, 4. Véase el caso expuesto en Feliciano Barrios "Solórzano, la Monarquía y un conflicto entre Consejos" en Derecho y Administración Pública en las Indias Hispánicas, Coordinador: Feliciano Barrios Pintado. Ediciones de la Universidad de Castilla-La Mancha, Cuenca 2002, vol. 1, pp. 265-283.

Véase mi Casuismo y Sistema..., cit., pp. 507 y ss. 
mostrar que la referida expresión "hagan justicia" servía a veces, para abarcar tanto el proceso en si como la decisión judicial, ambas sometidas a formas jurídicas. Así lo observamos en la real cédula de 26 de mayo de 1585 recogida por Solórzano - disponiendo que los obispos ordinarios no se entrometiesen en juzgar delitos de herejía y dejaran las causas a los Inquisidores para que "hagan... justicia" ${ }^{49}$ En el mismo sentido, el autor al enfatizar la superioridad de los oidores sobre los alcaldes de crimen en las audiencias, recordaba como dato fundamental que en las ordenanzas de las Chancillerías de Valladolid y Granada se establecía que los primeros "les manden, que hagan justicia" ${ }^{50}$

Las variantes pueden, en esta materia, ser infinitas. Bien vale, a mi juicio, referirse a una modalidad que surge de otra cédula recogida en la Política Indiana e interpretada por su autor. Es la expedida el 3 de junio de 1620 - no confundir con otra de la misma fecha citada anteriormente - dirigida a la Audiencia de Santa Fe en la cual se instruía al tribunal para resolver una cuestión planteada por el gobernador de Santa Marta, a raíz de la muerte del obispo de esa provincia, fray Sebastián de Obando. El prelado había donado bienes a sobrinos, parientes y criados, y al momento de la muerte "no se hallaron en su casa mas que la cama, y unas sillas viejas”. Ante este planteo, el fiscal del Consejo sostuvo que las donaciones entre vivos irrevocables con entrega real sólo serían válidas si, después de efectuadas, el donante hubiese vivido cuarenta días; y además que los bienes del obispo, no habiendo inventario, pertenecían a la Iglesia, y habiéndolo debía constar cuáles eran propios del obispo para que sobre los mismos se ejerciera el derecho de los herederos. El rey dispuso que, atendiendo a este parecer fiscal, "hagáis justicia”. Precisamente Solórzano hacia hincapié en esta expresión para resolver la duda sobre si se quiso o no inducir la solución, inclinándose por la primera alternativa. ${ }^{51}$ De tal modo, nos encontramos ante una norma especial dada para resolver la situación planteada, que se inducía a aplicar luego de un proceso sustanciado bajo formas jurídicas.

49 Politica Indiana, IV, XXIV, 23.

50 Ídem, V, V, 15. Sobre la expresión, véase la reflexión de Castillo de Bobadilla, cit., III, XV, $115-119$.

51 Ídem, IV, X, 35-37. 


\section{El enlace entre acepciones}

Una vez practicada la necesaria disección de la noción de justicia y peraltado el último sentido, es preciso hacer su recomposición pues no se trata de acepciones anárquicas o independientes. Entre ellas se percibe un enlace. Buen recurso encuentro en unas sugestivas huellas literarias que, guardadas por el propio Solórzano, son representativas de ese sentir. Se atribuyen a un pretendiente que, en Lima, acudió a nuestro oidor para pedir justicia y amparo. Dentro de un extenso romance y refiriéndose a las dotes de su destinatario decía:

"con mis méritos insertas

a fin de alcanzar justicia

y moveros a clemencia

porque se que ambas virtudes

acompañadas de sciencia

en vos en heroico grado

resplandecen y campean".

Y más adelante agregaba:

"viendo cual mal se conserva

(sin la justicia) la paz

$\mathrm{Y}$ estas dos sin la sapiencia" ${ }^{52}$

Estas muestras poéticas, muy del gusto solorciano, ${ }^{53}$ con las cuales se intentaba halagar al grave oidor, ponen otra vez en evidencia el lugar clave que esta noción de justicia ocupaba en el pensamiento del letrado madrileño, ya como virtud social y fin político, ya como prevalencia del saber de los juristas. Si dentro de las letras hispanas se percibe una exaltación transcendente de la justicia, sublime e impetuosa, ${ }^{54}$ en Solórzano hallamos esa estimación encauzada finalmente a través de la justicia emergente del proceso y el saber jurisprudencial. Las audiencias materializaban esa idea como "guardianes e interpretes del espíritu de justicia". 55

52 M. Rodríguez MoÑiño, "Manuscritos literarios peruanos en la biblioteca de Solórzano Pereira”, en Cahiers du Monde Hispanique et Luso-Brésilien Caravelle, núm. 7, Toulouse, 1966, p. 115.

53 Ibídem.

54 José M. Pemán, “La idea de justicia en las letras clásicas españolas”, en Revista de Derecho español y americano, núm. 15, Madrid, 1967, pp. 54 y ss.

55 Pérez Tudela, “La Política...”, cit., p. 169. También véase pp. 166 y ss. 
Solórzano depositaba su confianza en esta concepción, pese a sus defectos y vicios, y a la punzante crítica de los profanos, generalmente insatisfechos ante la mengua deparada por toda justicia regida por los hombres. ${ }^{56}$ Cuando en 1646 - poco antes de la publicación de la Política Indiana - el Consejo de Indias solicitó su parecer acerca de la visita de la Casa de Moneda de Potosí, Solórzano de modo enérgico sostuvo que ante los fraudes y excesos allí cometidos, no cabía la suspensión de la visita, como algunos pedían, ya que - enfatizaba - "nunca he visto que por hacer justicia se pierdan los Reinos como en las cartas se amenaza, antes se pierden por no hacerlo, y mas en cosas tan graves". Agregaba empero que "la dificultad está en hallar ministro entero, inteligente y prudente, a quien se pueda encargar esta visita” para que la justicia fuese rigurosa, ejemplificadora y sin tardanza. ${ }^{57}$ Justicia de hombres, al fin y al cabo...

56 Castan Tubeñas, La idea..., cit., p. 59.

57 Parecer fechado en 14 de agosto de 1646 (AGI, Charcas 113). 


\section{La variedad indiana, una clave de la concepción jurídica de Juan de Solórzano*}

Sumario: Introducción - I. La variedad, elemento de la realidad - 1. Los lugares, las tierras, las provincias - 2. Las gentes y las lenguas - 3. Los ánimos, las opiniones, las relaciones - 4. El tiempo - II. La variedad, sustento de la concepción jurídica - 1. La variedad de costumbres - 2. El legislador ante la variedad - 3. Las audiencias y la variedad local -4 . La regla frente a la variedad de los casos

\section{Introducción}

Estas páginas, nacidas de mi preocupación por encontrar los soportes de un orden jurídico complejo, como fue el Derecho indiano, están destinadas a aportar material al tema propuesto por la Real Academia de la Historia para este Congreso: "Factores de diferenciación e instancias integradoras en la experiencia del mundo iberoamericano".

No es enteramente novedoso lo que he de exponer, pues ya en anteriores trabajos míos puede descubrirse la misma idea, pero ahora me he empeñado en destacar la cuestión, dándole un perfil más nítido. Además, me parece de interés introducir en una reunión de historiadores generales un aporte proveniente de la historia jurídica, que ayudará a observar el lugar ocupado por el Derecho en el marco de la sociedad y cultura indianas y en la interrelación de influjos entre la mentalidad social y los juristas.

La figura de Juan de Solórzano Pereira (1575-1655) no necesita presentación ante los americanistas, ${ }^{1}$ pero estimo que sí es preciso hacer algunas

* Publicado en Real Academia de la Historia, II Congreso de Academias Iberoamericanas de la Historia. Actas. Madrid, 1994, pp. 475-488.

1 Sobre rasgos biográficos, véase: F. Javier de Ayala, Ideas políticas de Juan de Solórzano, Sevilla, 1946, pp. 41-57; Javier Malagón y José M. Ots Capdequí, Solórzano y la "Política Indiana”, México, 1965, pp.9-40; y Miguel OchoA Brun en su estudio preliminar a la edición de la Política Indiana de la B.A.E., Madrid, 1972. Como estudio general de Solórzano y su obra, véase, además del libro de Ayala, el trabajo de Juan Pérez de Tudela, "La 'Política Indiana' y el político Solórzano (Aproximación a un tema jurídico desde la metodología del historiador general)", en Revista de Historia de Indias, núms. 123-124, Madrid, 1971, pp. 77-171. Recientemente, Enrique García Hernán, Consejero de ambos 
consideraciones para mostrar que la elección de este tema no constituye un vano juego erudito, un ejercicio con más rigor especulativo que consecuencias prácticas para comprender aquella realidad americana.

El examen de esta cuestión lo haré en base a la Política Indiana, la obra más representativa y difundida de Solórzano, elaborada ya en la etapa madura de su producción, en donde condensó no sólo la experiencia vivida como oidor limeño, sino también la visión que le proporcionó su actividad como fiscal y ministro del Consejo de Indias. ${ }^{2}$ Dicha obra se reimprimió tres veces durante el siglo XVIII y se convirtió en un verdadero "libro de autoridad" en la esfera jurídica por el prestigio de su autor y por el carácter fijador que se le reconoció en un nivel comparable al alcanzado, en el orden legislativo, por la Recopilación de 1680. Al expresarme de este modo estoy suponiendo que el lector acepta mi punto de vista en el sentido de considerar a la jurisprudencia de los autores como fuente relevante del Derecho de la época. ${ }^{3}$

La Política Indiana adquirió un lugar principal dentro de este modo de creación jurídica. Desde 1647, año de su edición, fue creciendo en renombre hasta alcanzar, en la centuria siguiente, casi un reinado absoluto al punto que, por entonces, se decía que en el propio Consejo de Indias era "más fácil de separarse de la disposición de una ley, que de la autoridad de este escritor".

Ostenta el carácter de "libro fijador del Derecho" en razón de que Solórzano logró captar el pensar y el obrar jurídicos que lo rodeaba y supo plasmarlo en el texto. Como tal constituye un depósito del saber jurídico, en donde se acumulan leyes, costumbres, decisiones, ejemplos, opiniones,

mundos. Vida y obra de Juan de Solórzano Pereira (1575-1655). Fundación Mapfre, Madrid, 2007, la más completa biografía.

2 Para ubicación de la Política Indiana en el marco de la literatura jurídica del Barroco, véase mi trabajo "Elementos consuetudinarios en la 'Política Indiana' de Solórzano", en Revista de Historia del Derecho, núm. 15, Buenos Aires, 1987, pp. 472-476, luego incorporado a Víctor Tau Anzoátegui, El poder de la costumbre. Estudio sobre el Derecho consuetudinario en America Hispana hasta la emancipación, Buenos Aires, 2001, pp.311-315, cit.; y BernARdino Bravo Lira, "La literatura jurídica indiana en el Barroco", en Revista de Estudios Histórico-Jurídicos, X, Valparaíso, 1985, pp. 227-268.

3 "La doctrina de los autores como fuente del Derecho castellano-indiano", en Revista de Historia del Derecho, núm. 17, Buenos Aires, 1989, pp. 401 yss. Reproducido en el presente volumen $(\mathrm{V})$.

4 Alonso Varela de Ureta, Discurso político práctico, que propone cuál debe ser la formación del Consejo Real y Supremo de las Indias, Cádiz, 1733, pp. 34-35. 
etc. No todo lo que luce es juicio propio, original y exclusivo del autor. Resulta a veces difícil determinar la autoría de los mismos y la conformidad o no de Solórzano por lo que va asentando. El autor muestra su mérito al recoger, elaborar y exponer ese material. El resultado, más que el pensamiento puro del escritor, es una expresión jurídica colectiva. La larga vigencia de esta obra hace trasladar esta expresión más allá de su tiempo, con influencias sobre las nuevas generaciones de juristas, formando su mentalidad. En esto reside el mayor valor del contenido que he de examinar en una de sus nociones claves.

La Política Indiana está inserta en el mundo del Barroco. En la misma se perciben los elementos e ideas imperantes en el medio social de su época. Hace algunos años, ocupándome del derecho consuetudinario en dicha obra, afirmé que allí estaba "inocultablemente presente la idea de variedad". 51 despliegue de la cuestión me hubiese llevado entonces por caminos alejados de los que me proponía transitar. Hoy me parece ocasión oportuna para puntualizar con más atención esa noción de variedad como componente de la realidad y soporte de la concepción jurídica de la época.

\section{La variedad, elemento de la realidad}

Que la idea de variedad fuese aceptada y favorablemente estimada por la mentalidad del Renacimiento y del Barroco es difícil de comprender para quienes nos encontramos inmersos dentro de la proyección histórica de las tendencias uniformadoras y sistemáticas nacidas del racionalismo y que empezaron a desplegarse con fuerza en el siglo XVIII. Estas últimas precisamente no apreciaron la variedad como un elemento actuante en sí mismo, impuesto por la naturaleza de las cosas, que debía ser admitido como tal en la reflexión y elaboración intelectual. La admitieron sí como elemento primario que era preciso reducir a unidad, como resultado de la pretensión abarcadora de la razón sobre la naturaleza y la sociedad.

Sostiene Maravall que mientras ya la estimación de la variedad se impuso en el Renacimiento, fue en la época del Barroco cuando se profundizó esa atención, haciéndose de la variedad "tal vez el primero de los valores que el mundo encierra”. Así la hermosura de la naturaleza física radicaba en su

5 Tau Anzoátegui, “Elementos consuetudinarios...”, cit., pp. 491-492. También Bravo Lira, "La literatura...”, cit., pp. 259-260. 
variedad. El hombre mismo aparecía sujeto, en el despliegue de su vida, al principio de variedad. Variados se ofrecían los caracteres y ánimos de los hombres y sus facultades. Hasta el paladar se lisonjeaba con "la variedad de sabores y diversidad de gustos". La vista gozaba con la diversidad de trajes y piezas del atuendo personal. Los pueblos y razas ofrecían infinita variedad. Esta comprobación lleva a Maravall - de quien extraigo las líneas anteriores a afirmar que "la conciencia de la variedad, como un dato positivo enriquecedor de la experiencia y condicionante de los comportamientos humanos, informa la concepción barroca de la política y de la sociedad". ${ }^{6}$

Esta idea de variedad se desplegó con el descubrimiento del Nuevo Orbe y su extendida colonización. Es más, el desarrollo expuesto por Maravall tal vez sólo pueda abarcarse plenamente con la observación del fenómeno expansivo en tierras americanas. Diversos testimonios de los siglos XVI y XVII dan cuenta de cómo la cuestión era atendida en escritos a propósito de las más diversas materias. Solórzano no fue, en este sentido, original. Su aporte consiste en haber incorporado esa idea de variedad como componente de una realidad a la cual debía atender el jurista. En pos de obtener una fehaciente comprobación de esta elaboración solorciana, he entresacado de la Política Indiana no sólo juicios propios del autor sino otros pasajes en donde acumula materiales ajenos, ya sea expuestos en párrafos sustanciales o en expresiones incidentales. Veamos algunas muestras.

\section{Los lugares, las tierras, las provincias}

Empecemos con la referencia que Solórzano hacía sobre "la naturaleza, excelencias y cosas raras del Nuevo Orbe, de su comparación al Antiguo...”. Describía el fenómeno como proveniente de la misma Divinidad en párrafo que bien vale transcribir:

Habiendo dicho (aunque con brevedad) lo que basta para tener algún conocimiento de las muchas y dilatadas Provincias del Nuevo Mundo, me parece necesario decir algo en la misma forma de sus excelencias, utilidades y propiedades: porque no piense alguno que lo que tiene de inmenso, pierde su estimación por lo infructuoso y desaprovechado. Si bien no quiero, ni puedo negar, que hay mucho de este género en tantas ciénagas, pantanos, arenales, pedregales, sierras, montes, bosques y arca-

6 José Antonio Maravall, La cultura del Barroco. Análisis de una estructura histórica, Barcelona, 1975, p. 379. Para lo anterior, pp. 377-381. 
bucos impenetrables como en él se hallan. Y en algunas tierras que, o por el mucho calor, o por el mucho frío son poco aptas para ser habitadas. Pero esto no quita, ni impide que debamos celebrar y alabar lo que en las otras por la mayor parte, que hay de riqueza, templanza y amenidad. Porque esta desigualdad se halla en todas las del Mundo, no sólo después del Diluvio, sino desde el principio de su Creación. Disponiéndolo así su hacedor, para que resplandeciese más con esta variedad su Poder: y dando a unas Regiones unas cosas, a otras otras, y a otras ninguna constase, que todo pendió de su voluntad: y quedasen sus habitadores necesitados de buscarse y comunicarse, y no adorasen por Dios al Mundo, viéndole padecer semejantes imperfecciones. $^{7}$

Al referirse Solórzano a la "gloria y grandeza que han adquirido y se debe a los Reyes de España y a sus vasallos por el descubrimiento y conversión de este Nuevo Orbe", expresaba que nadie le podría negar a los españoles dicha gloria por haber puesto de manifiesto un Hemisferio "en que se han hallado tantas tierras y mares, tantas gentes, animales, riquezas, árboles, yerbas, drogas y otras cosas de precio y provecho". Y preguntaba que si se alababan a los hombres que inventaban algún arte u objeto de provecho para sus semejantes, "de que gloria no serán dignos los que han descubierto un mundo, en que se hallan, y encierra tan innumerables grandezas y riquezas? Un Cielo con tan nuevas y diferentes estrellas?..... 8

Lo inmenso y vario del Nuevo Mundo queda registrado en frecuentes expresiones incidentales al ocuparse de diversas materias. Así, cuando trataba del Consejo de Indias resaltaba que su atención se extendía a "todo un Imperio que abrazó en sí tantos Reyes, y tan varias, ricas y poderosas Provincias..."9 Cuando se ocupaba de la división de los obispados escribía que las provincias indianas se diferenciaban de otras del mundo "por ser ellas en sí tantas, tan vastas y dilatadas, y mediar entre unas y otras mil despoblados, y caminos fragosos e inaccesibles, y también porque la necesidad o utilidad de sus pobladores ha ido cada día haciendo nuevas colonias y poblaciones en los puertos que han parecido más convenientes....” ${ }^{\mathbf{1 0}}$ En fin, al referirse a las diferencias que existían entre el Nuevo y el Viejo Orbe, señalaba "la gran variedad de temples o climas que en breves distancias se suelen reconocer en estas Provincias de las Indias, en particular en las Peruanas...."11

7 Juan de Solórzano Pereira, Política Indiana (1647), edición utilizada, Madrid, 1776, I, IV, 1 y 2.

8 Ídem, I, VIII, 6.

9 Ídem, Dedicatoria al rey, núm. 20.

10 Ídem, IV, V, 3.

11 Ídem, I, IV, 26. 
La diversidad entre las provincias, antes que estéril, era provechosa. Decía al respecto que, según lo advertían los autores y lo manifestaba la experiencia, "ninguna tierra o provincia produce, ni lleva todas las cosas, de que puede y suele necesitar la vida, y comodidad de los hombres; sino que en unas se dan unas y en otras, otras con mayor particularidad o abundancia, ordenándole así el inefable Hacedor de ellas, como lo dice S. Juan Crisóstomo, para que con eso necesitasen unos de otros, y se conociese, comunicasen y mezclasen por medio de los comercios".

Solórzano se complacía en mostrar las tierras, los lugares y provincias como expresiones patentes de esa idea de variedad, concedida como un don divino y acentuaba su tono cuando se trataba de la visión del Nuevo Orbe.

\section{Las gentes y las lenguas}

La variedad radicaba asimismo en las gentes, sus trabajos y las lenguas. Dicha variedad de gentes ya la enseñaban Séneca y Cicerón. ${ }^{13}$ Lo cual le llevaba a expresar - con relación a la evangelización de los aborígenes - que "ni en todos los tiempos ni en todas partes, y gentes, se puede guiar de una misma manera". 14

Este tema adquiere su punto culminante dentro de la Política Indiana cuando Solórzano planteaba la cuestión acerca de la lengua y de la obligación de que los indios aprendiesen el castellano. Empezaba señalando el fenómeno de la propagación de las lenguas en el linaje humano y su extensión a remotas provincias. Esta idea que encontramos en textos y autores antiguos - dice - la

experimentamos más después que se descubrieron las Indias Orientales y Occidentales; pues según dice Genebrardo por relación de Américo Vespucio en cada cien leguas hay diferentes lenguas, y aun dentro de ellas a poca distancia el lenguaje que pudo parecer uno mismo, con alguna mudanza de letras o diferencia en el pronunciarle, acentuarle o accionarle, se hace tan otro que aun entre sí no se entienden los vecinos.

Y agregaba:

12 Ídem, II, XIII, 1.

13 Ídem, III, II, 18.

14 Ídem, I, X, 17.

212 Capítulo IX 
Lo cual reconoce también el Padre Acosta y otros, que hablando de sólo el Reyno que llaman del Perú, dicen que hay en él más de setecientas lenguas diferentes, y que apenas se habita valle o collado algo ancho que no haya introducido la suya. Y de aquí se ocasionaron en los primeros descubrimientos de estas dilatadas Provincias, y aun se ocasionan muchas dificultades, cuasi insuperables en penetrarlas, y en convertir y atraer a nuestra $\mathrm{Fe}$, amistad y comunicación sus habitadores.... ${ }^{15}$

La riquísima variedad en este punto no era exaltada ni apreciada por Solórzano. Más bien se la contemplaba en sus efectos negativos: la dificultad en la comunicación con esos grupos aborígenes. Y para remediar esta situación se postulaba la introducción de una lengua común, el castellano. Esta postura era tributaria de su época, en la cual la política regia estaba ya firmemente orientada a convertir la lengua de Castilla en general de América. ${ }^{\mathbf{1 6}}$

\section{Los ánimos, las opiniones, las relaciones}

En un párrafo medular, en el cual se explayaba sobre el proceder de los oidores, Solórzano afirmaba que "cuán ordinaria es entre los hombres la variedad de las opiniones y cuán natural la facilidad de disentir y discordar en sus juicios y pareceres...”. Agregaba que Cicerón con "su acostumbrada elocuencia nos enseña en su libro primero de los Oficios que como en los cuerpos, en los rostros, en el tono de la habla, y en los gustos y costumbres se diferencian, y fue conveniente, que se diferenciasen los hombres; así en los ánimos, opiniones y pareceres se hallan, y conviene que haya las mismas y aun mayores variedades". Aún más, siguiendo al mismo Cicerón expresaba que no era loable quedarse firme en un parecer porque "aun en un mismo negocio es lícito mudarle, si se varían los tiempos y las razones..." ${ }^{17}$

Al ocuparse de la perpetuidad de las encomiendas, anotaba que había "varias y encontradas opiniones y relaciones que siempre ha habido en él". Y explicaba - citando un autor - que en la ciencia legal y "generalmente en términos de la variedad, que en todo suele haber opiniones" ${ }^{18}$ También lo percibía en la sucesión de las encomiendas. La materia había recibido "varias

15 Ídem, II, XXVI, 2 y 3.

16 María Margarita Rospide, "La enseñanza del castellano en los Reinos de Indias a través de la legislación real", en Investigaciones y Ensayos, núm. 34, Academia Nacional de la Historia, Buenos Aires, enero-junio 1988, pp. 445 y ss.

17 Solórzano Pereira, Política..., cit., V, VIII, 31 y 37.

18 Ídem, III, XXXII, 10. 
formas y mudanzas, según la variedad de los tiempos, y de las relaciones que a nuestros Católicos Reyes se iban haciendo...."19

Según se aprecia, nuestro autor, bajo la guía ciceroniana, mostraba una complaciente aceptación de un rasgo propio de la personalidad humana y consideraba que esa variedad de ánimos, opiniones y pareceres enriquecía la misma vida social.

\section{El tiempo}

Maravall ha plasmado en certeras páginas la presencia, en la cosmovisión barroca, de otras dos ideas derivadas de la variedad y que contribuyen a explicarla mejor: las del movimiento y el tiempo. "Desde la esfera de las relaciones económicas - dice - hasta el campo de la ciencia o del arte, la temporalidad pasa a ser concebida como un elemento constitutivo de la realidad". Es que - agregaba - "el tiempo hace y rehace las cosas, las saca de ser lo que eran, en la corriente de una universal mutabilidad, y las renueva haciéndolas otras".20

En la textura de la Política Indiana la temporalidad es una dimensión que constantemente asoma, aunque no siempre en una misma dirección y a veces en juicios contrapuestos dentro del discurso dialéctico. Trataré de mostrar el empuje de estas ideas a través de algunas muestras representativas de los diversos enfoques que puede ofrecer esta cuestión.

En primer lugar, cabe observar que el tiempo era presentado por Solórzano como elemento siempre actuante sobre la realidad. A la ya recordada advertencia de que "ni en todos los tiempos, ni en todas partes y gentes, se puede guiar de una misma manera”, se puede agregar otra expresión incidental cuando, muy al gusto barroco, enfatizaba que "todo lo vencen las ocasiones que se van ofreciendo....”21 Pero, sin duda, es mucho más agudo aquel pasaje, inspirado en el Padre Acosta, en el cual se afirmaba que el Nuevo Orbe se componía de tantas provincias, en las cuales "cada día suceden nuevos e inopinados negocios, se recelan motines, y sediciones, se experimentan repetidas y peligrosas mudanzas...", siendo el estado mismo de la

19 Ídem, III, XVII, 2.

20 Maravall, La cultura del Barroco..., cit., p. 382.

21 Solórzano Pereira, Política..., cit., II, VI, p. 40.

$214 \quad$ Capítulo IX 
República "tan inconstante, vario y diferente en sí cada día, que las cosas que ayer se pudieron tener y juzgar por muy rectas y acomodadas, hoy, trocadas en todo, vendrían a ser muy injustas y perniciosas". 22 Buena muestra de esa visión barroca del dinamismo indiano.

Solórzano utilizaba con cierta frecuencia el recurso al tiempo para manifestar cómo se habían ido modificando las situaciones, pareceres o regulaciones en cuestiones concretas hasta llegar al estado en el que él escribía. ${ }^{23}$ Los tiempos y las ocasiones habían exigido esas alteraciones aun en un mismo negocio. ${ }^{24}$ Las propias Ordenanzas del virrey Toledo, tan respetadas y elogiadas, por su misma bondad admitían ser alteradas "si por la variedad del tiempo pareciere". ${ }^{25}$

También el tiempo era usado para argumentar a favor de la conservación de criterios y normas. Así, al establecer que los reyes siempre habían dispuesto que los tributos de los aborígenes fuesen moderados, nuestro autor decía que es "cosa que en otros varios tiempos y Provincias se ha ido mandando". ${ }^{26}$ Donde el tiempo se vuelve hacia una utilización más conservadora es cuando aparece integrado al fenómeno consuetudinario.

Cabe aún apreciar otro enfoque más en el tema que venimos considerando. Se trata del tiempo como factor que podía alterar, en el futuro, la visión actual y mejorar o perfeccionar el estado de las cosas. Es muy representativo al respecto el pasaje en el cual Solórzano se refería a la política de la Corona en punto a reducir a los aborígenes en pueblos. Sostenía entonces que, salvando los agravios y vejaciones cometidos en la ejecución de estas reducciones, "los mismos Indios, aunque al principio pueda ser que disgusten de ellas por estar hechos a sus antiguas e incultas costumbres, después con el tiempo ellos y mucho más los que de ellos nacieren, se hallarán muy contentos conociendo los provechos, que de este modo de vida y gobierno se les recrecen".27

22 Ídem, V, XII, 11.

23 Ídem, II, VI, 39; II, XX, 13; II, XXII, 23; III, XVII, 2; III, XXX, 11; y V, XII, 53.

24 Ídem, V, VIII, 37.

25 Ídem, II, XXIV, 18.

26 Ídem, II, XIX, 28.

27 Ídem, II, XXIV, 22. 
Se trataba, tal como se advierte, de vaticinar un cambio en la actitud de los aborígenes por el obrar del tiempo, trocando en positiva la introducción del criterio de reducirlos en pueblos.

El empleo del factor tiempo en el mismo sentido también se verifica cuando Solórzano se refería al diezmo de los indios. Decía que si del privilegio o costumbre de no diezmar "se comenzase a sentir que se les sigue a las Iglesias, y sus Ministros algún daño y perjuicio notable, se habrá de revocar y mandar que cese y se dé otra forma en que bastantemente se satisfagan; como lo dice una célebre decretal que trata de esta misma materia. En cuya fuerza dice Felino que cada día se casan y anulan muchos privilegios" ${ }^{28}$

\section{La variedad, sustento de la concepción jurídica}

Queda por mostrar hasta qué punto esa idea de variedad, que Solórzano invoca y aprecia en la descripción de la realidad indiana, nutrió su concepción acerca del Derecho y particularmente contribuyó a elaborar las respuestas que debieron darse a los problemas jurídicos que se plantearon en el Nuevo Mundo.

En la Política Indiana es dable observar de modo constante esta idea central que dominaba la jurisprudencia casuista: el Derecho no se crea especulativamente y por tanto no cabe establecer soluciones rígidas para aplicar sin más a los casos que ocurran. La búsqueda de definiciones, categorías y símiles se hacía en relación a las cuestiones concretas y no con propósito abarcador. La presentación de argumentaciones variadas, de opiniones contrapuestas y de plurales fuentes jurídicas contribuía al conocimiento y reflexión del jurista o ministro que enfrentaba los casos reales. Las opiniones que se ofrecían estaban destinadas a acercar - no a imponer - soluciones. En ocasiones, la indecisión o irresolución frente a dictámenes contrarios marcaba una postura prudente ante la variedad de los casos de aplicación. ${ }^{29}$ Esta convicción de los juristas, asumida por Solórzano, radicaba

- entre otros elementos - en ese fenómeno de la variedad en general, y particularmente de la variedad indiana. No se podía crear el Derecho ni establecer leyes que tuviesen carácter general y como tal fuesen aplicables

28 Ídem, II, XXIII, 36.

29 Víctor Tau Anzoátegui, Casuismo y Sistema. Indagación histórica sobre el espíritu del Derecho Indiano, Buenos Aires, 1992, p. 449.

216 Capítulo IX 
de modo universal. Leemos en la Política Indiana que "no hay ley que se ajuste y sea uniforme a todo el género humano" 30 Agregaba Solórzano que "cada Provincia las requiere diversas, como también lo son sus climas, lugares y habitadores" ${ }^{31}$ En concreto, afirmaba en otro pasaje, "cada Provincia necesita de leyes y costumbres particulares que ajusten a ella, como a cada paso nos lo enseña el derecho" ${ }^{32}$ Y proporcionaba, en fin, esta otra sentencia: "no se han de acomodar los lugares a las leyes, sino las leyes a los lugares....”33 Expresiones éstas que diseminadas - junto a otras análogas - en distintos capítulos y temas de la Política Indiana ofrecen una constante en el pensamiento solorciano, apareciendo conectada la idea de variedad con los modos de creación jurídica.

Para desplegar la cuestión he elegido algunos aspectos específicos, con muestras representativas de textos solorcianos, en los cuales luce, explícita o implícitamente, dicha conexión.

\section{La variedad de costumbres}

La costumbre como modo de creación jurídica aparece peraltada en el Derecho indiano y es objeto de una constante atención en la Política Indiana. Como señalé en otra ocasión, no cabe hacer una gradación de las fuentes del Derecho, pues al operar de manera casuística Solórzano - y con él los juristas de la época - no estaban preocupados por establecer una jerarquía de las mismas. Según se comprueba a través de la obra, nuestro jurista otorgaba a la costumbre un amplio alcance en los casos que iba resolviendo, pudiendo llegar su fuerza hasta contradecir a la ley. En algunas materias ese vigor se acrecentaba al hacer su defensa en tópicos particulares. ${ }^{34}$

El carácter local de la costumbre afirmaba su variedad. Solórzano, recogiendo una antigua convicción, decía que "no menos diferentes suelen ser las costumbres de cada región, que los aires que las bañan y los términos que las dividen" ${ }^{35}$ En otro pasaje expresaba que "como lo enseña el derecho, cada Iglesia y Provincia tiene sus costumbres y se ha de regir y juzgar por ellas, y

30 Solórzano Pereira, Política..., cit., V, XVI, 3.

31 Ibídem.

32 Ídem, II, VI, 23.

33 Ídem, V, III, 48.

34 Véase mi trabajo "Elementos consuetudinarios", pp. 482-485.

35 Solórzano Pereira, Política..., cit., II, XXV, 9. 
conforme a ellas, sin que los Príncipes sabios y prudentes quieran, puedan ni deban alterárselas; sino antes conservar a cada una enteramente en el estado de las que tienen" ${ }^{36}$ Esto mismo se afirmaba en otra ocasión al decir que cada Provincia tenía "sus reglas y costumbres, con que la suele medir y diferenciar" y de ellas debíamos valernos. ${ }^{37}$ Al tratar una materia concreta - la exacción y cobranza de la cuarta funeral - apuntaba que "no se han de atender ni atienden hoy tanto las disposiciones del derecho, como las costumbres de cada Provincia....”38 Insistía en otro lugar que cada provincia "como se suele diferenciar en temples, usos y condiciones, así se ha de gobernar con sus leyes y costumbres particulares..."39

Esta localización de la costumbre no era, sin embargo, absoluta. Admitía costumbres más generales y otras en expansión, lo que revela un dinamismo que enriquece la noción de la variedad, que también adquiere dimensión temporal. En este punto se percibe cierto espíritu conservador, propio del Barroco, que Solórzano adoptaba. Su criterio quedaba encerrado en este lacónico juicio: "lo que se ha de procurar, es continuar y conservar lo bien proveído, mejorar lo que pareciese que pide nuevo remedio..., que aplicaba a nuestro tema al decir que "no se deben mudar con facilidad las costumbres antiguas de las Provincias, pues cada una abunda en las suyas" ${ }^{40}$ Ello lo llevó a defender, a veces a ultranza, determinada costumbre, fundándose en su antigüedad y a recomendar a los legisladores que se pronunciaran contra las novedades y las mudanzas de las costumbres.

En fin, dentro de la discusión dialéctica de las diversas cuestiones planteadas en la obra, aparecían contrapuestas opiniones innovadoras y conservadoras. Ejemplo de ello es cuando presentaba con extensión los argumentos en torno a la conveniencia o no de la perpetuidad de las encomiendas. Entre los primeros, decía, se apuntaba que "no debemos persistir tanto en las leyes y costumbres antiguas, que no podamos loablemente introducir otras, si viéremos que aquéllas, o ya por el tiempo, o por la malicia de los hombres no puede llevarse adelante sin grave detrimento de la República, porque cada edad trae las suyas...”. Entre las segundas se argumentaba que se debía ir con

36 Ídem, IV, XVII, 4.

37 Ídem, II, XXIX, 33.

38 Ídem, IV, XXII, 9.

39 Ídem, III, XXIII, 38.

40 Ídem, III, XXVI, 30; y V, III, 48.

218 Capítulo IX 
"gran tiento y recato en no mudar las leyes y costumbres antiguas, y por largo tiempo observadas mientras que en las nuevas que tratamos de introducir no se hallare grandísima y evidentísima utilidad”. ${ }^{\mathbf{1}}$

\section{El legislador ante la variedad}

Solórzano escribió algunos párrafos medulares sobre la actitud que el legislador debía adoptar ante esa variedad que brotaba de la realidad indiana. Lo hizo en el curso de consideraciones generales o al abordar algún punto concreto, cuidando siempre de recoger autores y opiniones que apoyaran sus dichos.

Así expresaba que el "buen legislador" debía siempre "acomodar sus preceptos según las regiones y gentes a quien los endereza, y su disposición y capacidad, como lo enseña San Isidoro y otros autores, y con su industria y humanidad mirar y disponer lo que les pueda convenir como más les convenga...." ${ }^{42}$ Y en otro pasaje, al volver sobre el tema, decía que así "como el pulpo muda colores según el lugar donde se pega: así el Legislador que es atento y prudente, debe variar sus mandatos según las Regiones, a cuyo gobierno los encamina, y esta es su mejor ley”. Traía entonces a colación el comentario que Erasmo hacía sobre un adagio en estos términos: "Que según el lugar, conviene, que en unas partes hagamos esto y en otras aquello" ${ }^{43}$ Esto - agregaba - es tan cierto que "no puede darse ley antigua de tal suerte uniforme, que cuadre y ajuste en todas partes, igualmente a todo el género humano". ${ }^{44}$

Este criterio, expresado en el curso de una contraposición de opiniones aparecía ya como propio de Solórzano cuando se refería concretamente al Consejo de Indias. Decía entonces que las leyes que "deben acordar y consultar los del Consejo, sean las que fuese pidiendo el tiempo y la utilidad, y conveniencia de aquellas Provincias y Repúblicas". ${ }^{45}$ Más adelante afirmaba que dicho Consejo ha procurado gobernar y contener las provincias indianas “con leyes y ordenanzas, no sólo justas, sino ajustadas y convenientes a lo que

43 Ídem, II, VI, 23.

44 Ídem, II, VI, 24.

45 Ídem, V, XVI, 3. 
el gobierno, temple, disposición y necesidad de cada una de ellas le ha parecido convenir, dejando en lo demás en su fuerza y vigor las comunes y generales que están dadas y promulgadas para los reinos de Castilla y León...."46

Solórzano apuntalaba este criterio, invocando su propia experiencia. Cuando con otro oidor limeño, Alberto de Acuña, recibió el encargo virreinal de formar las Ordenanzas del Consulado de Lima, decía que fueron "tomando de las de México, Sevilla y otros Consulados lo conveniente, y añadiendo lo demás que pedía el tiempo, y disposición de la tierra para donde se hacían..." 47

De tal modo, se puede apreciar cómo la Política Indiana ceñía al legislador a respetar la variedad surgida de la naturaleza de las cosas y a dar sus preceptos conforme a las necesidades y modalidades locales. La variedad luce así como criterio orientador en la actividad del legislador.

\section{Las audiencias y la variedad local}

En la misma dirección que vengo apuntando puede observarse que Solórzano consideraba a las audiencias como sostenedoras de dicha variedad. Así, al interpretar una disposición real que había mandado guardar la costumbre ante la pretensión del virrey de Lima de imponer el criterio dominante en México, decía que "en cada Audiencia se guardase el estilo que se había tenido por lo pasado, en conocer de las competencias". ${ }^{48}$ No se trataba, por cierto - y esto me interesa subrayar - de una opinión solitaria ni ocasional. Ya en 1629, siendo fiscal del Consejo, había dictaminado - con aprobación ulterior del Cuerpo - en un expediente sobre aplicación en Chile de una bula papal, en el mismo sentido: "las audiencias tenían facultades para hacer recoger las bulas 'en los casos que convenga', siendo un asunto que debía resolverse en el ámbito local”. ${ }^{49}$ Era, pues, necesario preservar el "estilo" de las audiencias en función de esa peculiaridad regional que se imponía con la fuerza emergente de la naturaleza de las cosas.

46 Ídem, V, XVI, 11.

47 Ídem, VI, XIV, 25.

48 Ídem, VI, XIV, 26.

49 Archivo General de Indias (Sevilla), Indiferente General, 1464.

$220 \quad$ Capítulo IX 
4. La regla frente a la variedad de los casos

La idea de variedad, centro de nuestras preocupaciones en esta ocasión, encuentra lugar, en fin, en la mentalidad casuista de los juristas indianos. El caso planteado, con sus propias circunstancias, era objeto de preferente atención. Se descontaba que las leyes no podían abarcar todas las situaciones que ocurriesen, dada las infinitas variantes que éstas presentaban. ${ }^{50}$ En la Política Indiana se trasluce esta concepción, propia de la época y afirmada sobre todo al verificar la realidad indiana. Un texto nos sirve de ejemplo. Frente a la regla de que la muerte acababa con las pesquisas de los delitos y sus eventuales penas, Solórzano afirmaba: "pero aunque es verdad que esa sea la regla no podemos, ni debemos medir con ella igualmente todos los casos que se ofrecen en esta materia; porque éstos se alteran y varían, según la diferencia y variación de sus calidades y circunstancias. Y la misma regla tiene en sí tantas falencias y limitaciones, que de ellas se podría hacer otra no menos cierta, y casi tan general...." ${ }^{51}$

Se puede completar este testimonio con otro que reafirma esta visión solorciana sobre la falibilidad de la regla ante la cambiante realidad que ofrecían los negocios indianos. En punto a la acumulación de encomiendas decía que "en tales materias, y en Provincias tan remotas, y donde tan fácilmente se truecan las cosas, muchas dispensaciones y disimulaciones pide la ocurrencia, y congruencia de los negocios, y la diferencia de los tiempos, y las personas, y la prudencia consiste en la connivencia, que es, no lo querer apurar todo, ni llevarlo por el sumo rigor del derecho, haciéndonos desentendidos de sus puntos, y tolerando semejantes transgresiones algunas veces". 52

Como epílogo cabe expresar que los ejemplos expuestos en estas páginas muestran la fuerza que la idea de variedad tenía en el examen de la experiencia indiana y también ponen al descubierto la conexión de aquella idea con el ordenamiento jurídico. Como afirmaba al empezar, la Política Indiana nos sirve de texto adecuado por su representatividad, por su carácter "fijador" de la jurisprudencia y por su larga vigencia en la esfera indiana, para comprobar la presencia de esa idea en la época del Barroco y sus efectos en la concepción jurídica posterior.

50 Tau Anzoátegui, Casuismo y Sistema..., cit., pp. 319 y ss.

51 Solórzano Pereira, Política..., cit., V, XI, 5.

52 Ídem, III, VI, 67. 



\section{La disimulación en el Derecho Indiano*}

Sumario: 1 . Planteo del tema - 2. Trayectoria histórica y configuración indiana 3. El discurso jurídico de Solórzano - 4. Entre textos legales - 5. En el mundo literario - 6. Cuestiones abiertas

\section{Planteo del tema}

Una visión del Derecho indiano entendida como orden normativo cerrado, exclusivamente legal, gozó de amplio consenso entre historiadores de varias generaciones. En las últimas décadas, puntos de vista más amplios empezaron a destacar otros modos de establecer el Derecho - costumbre, autores, estilo, etc. $-\mathrm{y}$ a reconocer la existencia de diversas potestades, jurisdiccionales y normativas y aun de poderes informales. Como consecuencia, se ha agudizado el interés por observar el tejido de la experiencia jurídica. Para avanzar en esta tarea es preciso conocer los mecanismos actuantes en el espacio que separaba la norma de su efectiva aplicación. La disimulación operaba en este ámbito.

Esta figura - parece necesario decirlo, aun a riesgo de caer en lo obvio solo puede concebirse dentro de un orden jurídico caracterizado por reunir preceptos de diverso origen, naturaleza y alcance, que se invocan y aplican a los casos y situaciones, según fuese la materia, las personas y las circunstancias de cada uno. Lejos pues de tratarse de un conjunto de leyes abarcadoras de estricta aplicación. El jurista de entonces descreía del valor absoluto de las leyes generales.

* Publicado en Derecho y Administración Pública en las Indias hispánicas. Actas del XII Congreso Internacional de Historia del Derecho Indiano (Toledo, 16 a 21 de octubre de 1998). Coordinador: Feliciano Barrios Pintado. Ediciones de la Universidad de Castilla-La Mancha, Cuenca, 2002, vol. II, pp. 1733-1752. Tanto durante la elaboración del trabajo como en el momento de la exposición en el Congreso varios colegas me hicieron llegar sus opiniones y datos concretos que me han permitido enriquecer la redacción final. Entre ellos, debo agradecer particularmente a los doctores José M. Mariluz Urquijo, Bernardino Bravo Lira, Eduardo Martiré, Abelardo Levaggi y Nelson Dellaferrera. 
Dentro de ese abigarrado tejido normativo hay intersticios que dan cierta libertad de acción a individuos o corporaciones para operar conforme a sus prácticas e intereses. Allí aparecen privilegios, excepciones, dispensas y también silencios, tolerancias y disimulaciones para moderar el rigor de ciertas normas; se admiten suplicaciones y actúan asimismo la equidad y el arbitrio judicial para templar la aplicación en los tribunales. Eran instrumentos a los que acudía el jurista para encontrar soluciones flexibles ante determinados hechos o situaciones reacios a someterse a las reglas vigentes. Mientras tanto el contexto político de la época participa de esta cosmovisión al tener por regla de oro que "el rey antes debía ignorar y perdonar que castigar, aunque fuera en detrimento de una rigurosa aplicación del Derecho". Debía procurar hacerse amar más que temer. ${ }^{1}$ De ahí la abundancia de gracias y perdones.

Esta cosmovisión resulta ajena a la mentalidad del jurista contemporáneo. El Derecho es concebido por éste como un sistema legal omnicomprensivo establecido por el Estado que se aplica deductivamente en su rigor literal, sin distinción ni elasticidad alguna. Aunque el modelo no funcione en la práctica siempre así, al menos ese criterio es dominante en el discurso teórico que ha formado la mentalidad de los egresados de las aulas jurídicas desde hace más de una centuria. En estas condiciones, para el modelo dogmático carecen de razón de ser los mecanismos que permiten contrastar las normas con la cambiante realidad social y con las circunstancias que rodean a las situaciones y casos concretos. Así la figura de la disimulación ha quedado fuera del campo de conocimiento y del léxico técnico del jurista actual.

La lectura de textos antiguos con "lente dogmática" es pues a todas luces defectuosa, ya que no permite descubrir los criterios propios de los juristas ni la mentalidad de la época. Las sucesivas generaciones de juristas e historiadores formados bajo el modelo dogmático no alcanzan a percibir en aquellos viejos textos el espíritu de ese "otro" Derecho, como es el anterior al siglo XIX. Naturalmente esto es más evidente con todos aquellos principios y figuras que han sido expulsados del conocimiento dogmático.

No es de extrañar pues que las huellas de aquellos antiguos mecanismos de aproximación entre normas y realidad estén en los mismos textos habitualmente usados por los historiadores - leyes, libros de jurisprudencia,

1 Antonio M. Hespanha, “La senda amorosa del Derecho”, en Carlos Petit (ed.), Pasiones del jurista, Madrid, 1997, p. 39. 
obras literarias, etc. - y, que nos serán notorios si practicamos una lectura despojados de aquella "lente dogmática". Vocablos, giros, frases atesoran en esos textos un sentido que, con el transcurso del tiempo, se ha oscurecido o perdido. Suelen pasar rápidamente bajo nuestros ojos sin suscitarnos interrogantes o en todo caso sin que percibamos su genuino significado. Es que si en todo lector hay una tendencia irresistible hacia la "actualización del texto", esto parece más evidente en los de índole jurídica, donde esa percepción ha sido una constante en todos los tiempos por exigencias profesionales y desde luego, como en nuestro caso, por la introducción de nuevos métodos y modos de encarar el fenómeno jurídico.

La disimulación está vinculada a la observancia del Derecho y ocupa un lugar dentro de la jurisprudencia casuista indiana. Se acudía a ella en la legislación, en las obras jurisprudenciales y en la práctica de gobierno. Es lo que me interesa perfilar en este ensayo, sin caer en una 'purificación' jurídica de la figura, pero sin confundirla con otras formas en que también aparece la disimulación, en especial la resonancia política que adquiere en el contexto de la Corte y el cortesano en la misma época del Barroco. Ella se hizo muy intensa sobre todo en Italia, donde la literatura política y moral acunó una infinita controversia acerca de su utilidad, honestidad y aun legitimidad. ${ }^{2}$ Sin descartar una eventual vinculación con nuestra figura jurídica, no percibo claramente esa relación más allá de algunos rasgos de semejanza, y más bien creo que tuvieron características distintas, que tienen su correlato en diferentes usos semánticos de la voz.

La reconstrucción de esta figura requiere una paciente indagación empírica que se hace más vacilante si tenemos en cuenta que la antigua jurisprudencia, más práctica que teórica, no se ocupó de hacer una presentación conceptual de la misma. En el sentido que aquí nos interesa, hace más de medio siglo el maestro Rafael Altamira abrió camino en la observación de

2 Es en este sentido que Torquato Acceto definía la disimulación como el ingenio de no hacer ver la cosa como es. Se simula aquello que no es, se disimula aquello que es (Della dissimulazzione onesta, 1641). Sobre esta cuestión véase R. VIllari, Elogio della dissimulazione. La lotta política nel Seicento, Roma, 1987; Antonio M. Hespanha, "La Corte", en ídem, La gracia del Derecho. Economía de la cultura en la Edad Moderna, Madrid, 1993, pp. 178-181; José Antonio Maravall, Teoría del Estado en España en el siglo XVII, $2^{\mathrm{a}}$ ed., Madrid, 1996, pp. 256-260; ídem, "Maquiavelo y maquiavelismo en España”, en ídem, Estudios de Historia del Pensamiento Español, vol. III, Madrid, 1984, p. 52. En este punto me han sido muy útiles los juicios y aportes de Bernardino Bravo Lira. 
este vocablo. Lo hizo con su estilo característico dentro de las limitadas posibilidades de acceso a las fuentes históricas que tenía entonces, sacando cuestiones a la luz, planteando dudas, apuntando sugerencias. Se ocupó de la disimulación sólo en forma marginal, sin alcanzar a elaborar monográficamente el tema. Lo hizo en diversos pasajes de su estudio sobre la costumbre jurídica en la colonización española. Luego también volcó observaciones de interés al tratar la voz en el Diccionario de palabras utilizadas en la legislación indiana. ${ }^{3}$ Por haber residido mucho tiempo fuera de España, Altamira solo dispuso de pocas fuentes históricas para elaborar esos trabajos. La preocupación de Altamira por buscar un Derecho indiano que trascendiera del campo legislativo lo condujo seguramente a resaltar este vocablo, aunque me parece que no alcanzó a percibir todo su significado ni pudo recrear su curso de acción. Junto a ésta hay que ubicar otra inquietud del maestro español: mostrar las lagunas del Diccionario académico en punto a palabras o acepciones que habían alcanzado particular desenvolvimiento en las Indias. Pese a aquellas deficiencias y a cierto desorden argumental que le era propio, Altamira nos legó los primeros hilos para empezar a tejer el tema que estamos considerando.

En Casuismo y Sistema 4 me ocupé brevemente de la disimulación como ejemplo del mecanismo destinado a templar el rigor de la ley. Lo consideré entonces como "un instrumento propio de la concepción casuista" e ilustré la exposición con un párrafo medular de Solórzano y con un caso de aplicación. El asunto quedó en el telar con vistas a un futuro tratamiento. Ahora ofrezco unas aproximaciones que dan consistencia a su base conceptual y permiten observar su arraigo indiano, acudiendo a algunas muestras representativas de la jurisprudencia de los autores, de la legislación y del mundo literario.

3 Rafael Altamira, "Estudios sobre las fuentes de conocimiento de la Historia del Derecho indiano. La costumbre jurídica en la colonización española", en Revista de la Escuela Nacional de Jurisprudencia. UNAM, México, 1946-1948, núms. 31-40, particularmente núm. 33, p. 228; núm. 34, pp. 147-148 y 152; y núms.35-36, pp. 241, 314 y 325. Rafael Altamira, Diccionario castellano de palabras jurídicas y técnicas tomadas de la legislación indiana, México, 1951, voz "Disimulación”, pp. 114-115, 349-350 y 354.

4 Víctor Tau Anzoátegui, Casuismo y Sistema. Indagación histórica sobre el espíritu del Derecho Indiano, Buenos Aires, 1992, pp. 522-525. 


\section{Trayectoria histórica y configuración indiana}

Nuestra figura - o institución, como la denomina Charles Lefebvre ${ }^{5}$ - no es creación indiana. Siguiendo a este autor podríamos señalar que sus orígenes son estrictamente canónicos. Es más, Paolo Grossi considera que es institución exclusiva y típica del Derecho canónico. ${ }^{6}$ Hay ejemplos que atestiguan su antigua práctica. Ya a mediados del siglo XII, en la época del Decreto de Graciano, parece consolidado el sentido técnico del vocablo. Los canonistas la entendían como una cierta tolerancia, que eximía al superior de intervenir y oponerse al acto indiscriminado. No era ni dispensa, ni aceptación, tan solo era una "tolerancia provisoria". Esta tradición canónica se recogió en algunas decretales del papa Alejandro III (1159-1181) en materia matrimonial y quedó así plasmada la figura en textos oficiales. Se reafirman entonces sus características: conocimiento de parte de la autoridad de una situación irregular; imposibilidad de remediar ésta; ignorancia simulada del carácter reprensible de ese acto y como consecuencia ausencia momentánea de una intervención oficial ${ }^{7}$ Consiste, en fin, en la actitud evasiva de un superior ante un ilícito a fin de evitar un ilícito mayor. ${ }^{8}$

La teoría en elaboración parece debilitarse cuando Raimundo de Peñafort recopila estos textos pontificios en el Liber Decretalium, promulgado en 1234 por el papa Gregorio IX: solo reúne dos decretales que recurrían a la disimulación. Por entonces, los canonistas centraban la discusión acerca de si la disimulación debía asimilarse a una dispensa tácita o era una institución de naturaleza particular. Si bien las opiniones estaban divididas, en ese momento se impuso la primera alternativa. A partir del siglo XVI la cuestión fue revisada y esta vez, bajo la doble influencia de moralistas y humanistas, se sostuvo el segundo criterio. Las diferencias entre la disimulación y las instituciones vecinas, como el silencio, la tolerancia y la dispensa tácita fueron desde entonces mejor percibidas.

5 Ch. Lefebvre, "Dissimulation”, en R. Naz (dir.), Dictionnaire de Droit Canonique, t. IV, París, 1949, col. 1296-1307.

6 Paolo Grossi, L'ordine giuridico medievale, Laterza, Roma, 1995, p. 214. Hay edición española, Madrid, 1996.

7 Lefebvre, "Dissimulation", cit. Un amplio estudio sobre el tema en Giuseppe Olivero, Dissimulatio e Tolerantia nell' ordinamiento canónico (Milano, 1953) en ídem, Studio Canónica, Milano, 1987, pp. 5-196.

8 Grossi, L'ordine..., cit. 
En contraste con esta rica y sutil elaboración canónica, las leyes romanas, según Lefebvre, no ofrecen a los canonistas puntos de apoyo para encuadrar esta teoría, como sí ocurre con otras instituciones. El vocablo, que no se encuentra frecuentemente en el Digesto o en el Código, carece del sentido dado en la tradición canónica.

¿Cuál fue el camino que llevó de una disimulación canónica casi restringida a materia matrimonial a la más amplia configuración alcanzada en las Indias? ¿Fue a través de la misma disciplina canónica o del derecho civil común? ¿La recepción fue directa o por medio de la vía castellana? Son preguntas que hoy no tienen respuestas precisas. Unos pocos testimonios aislados, pero de peso, nos acercarán a una explicación provisional.

Un documento toledano depara el primer ejemplo. Transcurría el año 1547 y en la Iglesia Catedral de Toledo se debatía en el capítulo la introducción del requisito de "limpieza de linaje" para aspirar a los cargos beneficiados. La votación dio un amplio triunfo a la propuesta que había sido promovida por el mismo Arzobispo. Pero entre los votos contrarios había uno, cuya argumentación gira en torno a nuestra figura. Era voto solitario pero aun así merece atención por la forma en que alega la disimulación. El votante - identificado como doctor Peralta - sostenía que la introducción de ese requisito iba a generar disputas y odios, que siempre se levantaban cuando se trataba de averiguar el linaje y la raza de los pretendientes. Él estimaba que había que seguir en esta materia la conducta de los antiguos prelados que establecieron la regla adecuada. Bien vale atender al núcleo de este voto: decía el doctor Peralta que si "en tiempo de herejías grandes que andaban en España disimularon en semejantes estatutos los prelados antepasados habiendo entre ellos tanta gente santa y tanta gente docta, tanta gente ilustre, tan prudentísimos que por su prudencia no solo les encargaron el gobierno del Arzobispado más [sic] de toda España, disimularon también los capitulantes pasados siendo hombres sapientísimos y doctísimos razón sería que disimulasemos nosotros, en tiempos que por gracia de Dios está todo pacífico con gran Cristiandad". ' La disimulación, encadenada a través de varias generaciones, se asociaba argumentalmente nada menos que con la

9 El manuscrito existente en la Real Academia de la Historia está glosado en Julıo Caro Baroja, Toledo, Barcelona, 1988, pp. 109-112. Las palabras en bastardilla en esta transcripción y en las siguientes se han colocado para destacar el vocablo dentro del texto. Se advierte la falta de una palabra que no hace a la comprensión del texto. 
santidad, la prudencia y la máxima sabiduría ¿Era posible argumentar de este modo en ámbito tan selecto sino hubiese un cierto grado de reconocimiento hacia la figura de la disimulación y una aceptación de su utilidad?

Veamos otro dato: ¿cómo se usa el vocablo disimulación en la Política para corregidores de Castillo de Bobadilla, un clásico de la literatura jurídica castellana de fines del siglo XVI? Se puede observar en este texto que es frecuente referirse a la disimulación como acto o conducta reprobable de omisión en jueces y otras justicias, pero también hay pasajes donde reluce el sentido positivo de la figura, como aquel en que empezando con una cita del Eclesiastés, sostenía que las leyes debían guardarse "en cuanto convienen, porque muchas veces se debe disimular con ellas; y así es, que el juez inconsiderado más daña con ejecutar rigurosamente las leyes, que el sabio disimulando con ellas". ${ }^{10}$ Despunta en este elogio de la disimulación, enlazada con fuentes bíblicas, el carácter general que adquiere, extendido a la aplicación genérica de las leyes ¿Era este un sentir generalizado en el universo jurídico de Castilla?

Un tercer ejemplo comprobatorio nos lleva a verificar el uso social de la voz, a través de diccionarios, vocabularios, refraneros de la lengua castellana, partiendo de la idea de que las transformaciones léxicas suelen encubrir procesos de evolución conceptual. La indagación tiene en nuestro caso una notoria limitación dado que la publicación de la mayoría de esos repertorios es tardía con relación al período de auge de nuestra figura. Pero aún así la exploración no es vana, porque una voz compleja como la examinada, ofrece distintos significados y en todo caso necesita verificarse cuál es la presencia del sentido o matiz jurídico que estamos empeñados en resaltar. En un esfuerzo de síntesis podemos reducir los diversos sentidos a tres principales, a saber: ${ }^{\mathbf{1 1}}$

1. Encubrir con astucia la interacción; ocultar lo que uno siente o padece; y disfrazar o desfigurar las cosas.

2. Desentenderse del conocimiento de una cosa, generalmente a raíz de tolerar un desorden, afectando ignorancia.

3. Perdonar, permitir, dispensar.

10 Jerónimo Castillo de Bobadilla, Política para corregidores..., II, III, 1.

11 Sebastián de Covarrubias Orozco, Tesoro de la lengua castellana o española (1611), ed. utilizada, Barcelona, 1943; Real Academia Española, Diccionario de autoridades, Madrid, 1726; P. Esteban Terreros y Pando, Diccionario castellano con las voces de ciencias y artes..., Madrid, 1788; Martín Alonso, Enciclopedia del idioma. Diccionario histórico y moderno de la lengua española (siglo XII al XX)..., Madrid, 1982. 
Múltiples lazos pueden unir a estas tres acepciones. La primera - con distintos matices - es muy difundida en el habla corriente antigua y moderna. Tiene también, según se ha visto, fuerte presencia en el pensamiento y praxis política de los siglos XVI y XVII. Sin dejar de reconocer conexiones con el mundo del Derecho, este matiz de la voz no corresponde considerar aquí. Nuestro camino tiene otra dirección.

Son las dos acepciones restantes las que caen precisamente en nuestra órbita, pero ninguna de ellas por separado resultan satisfactorias para explicar la figura tal como se manifestaba en la vida jurídica. Una sólo recoge un enfoque parcial y aun así no es abarcativa de todas las situaciones, según veremos. La otra pasándose al otro extremo, reviste a la disimulación de un poder que precisamente no tuvo. En realidad no puede equipararse a un perdón. Tampoco es una dispensa, ni tan siquiera tácita. La más aceptable es la de permitir, aunque carece de precisión. Curiosamente esta tercera acepción que tiene más pronunciado matiz jurídico no aparece enunciada en los repertorios con fuerza testimonial. Así vemos que el Diccionario académico de 1726 le otorgaba un uso solo residual u ocasional, al presentarla como última acepción de la voz y con esta modalidad: "Suele usarse alguna vez por dispensar, permitir, perdonar".

Estas acepciones se visten de sentido valorativo en los refranes. Elijo tres que marcan la virtud y arte de esta figura, en cuanto resulta aplicable a nuestro objeto: "quien no sabe disimular del saber está en el empezar"; "Prudencia es disimular no querer la cosa no pudiéndola alcanzar"; y "Procura disimular lo que no puedas remediar". Saber, prudencia y conveniencia eran ejes de estos refranes que pueden hacerse converger en este otro lacónico: "Para bien gobernar, bien disimular".

Estos datos del uso lingüístico deben precisarse. La carencia de fechas exactas les da solo valor de aproximación temporal. Se puede presumir que en estos repertorios se recoge fundamentalmente el habla y los giros castellanos y nos los de Indias, o éstos al menos en mucha menor medida cuando se diferencian de aquellos. Es sugestivo que en los diccionarios castellanos la definición jurídica de la voz sea insatisfactoria, mientras en los refranes apreciamos tonos valorativos que guardan relación con la figura que venimos examinado.

12 Antología de dichos jurídicos y éticos tradicionales, compilados por Marcos G. Martínez, Madrid, 1986, p. 142. 
Si bien los testimonios aislados que he presentado no pueden reconstruir la trayectoria de esta figura jurídica, permiten al menos observar su presencia en la Castilla del siglo XVI, con lo que podría afirmarse presuntivamente que por ésta vía se operó su transmisión a las Indias. A primera vista, esa trasmisión dio lugar a una peculiar configuración indiana de la disimulación, acaso con dimensión mayor que la conocida en Europa. Esto se explica por las características del nuevo ordenamiento. Desde la misma época del Descubrimiento se percibe en América una estimación de lo fáctico como elemento de la juridicidad, que se apoyaba en las nociones de diversidad, mutabilidad y distancia. ${ }^{13}$ El gobierno de las Indias requería un orden jurídico abierto y plural, maleable y dinámico que, sin descuidar sus principios rectores, ofreciese "válvulas de escape" para adecuar la aplicación de las normas. La disimulación se inserta allí como uno de estos instrumentos dúctiles. No me parece aventurado plantear en este aspecto un posible paralelismo mutatis mutandi, entre el Derecho canónico y el indiano.

Los datos hasta ahora conocidos permiten observar a esta figura en Indias desde mediados del siglo XVI. La época de auge, coincidente con el esplendor de la jurisprudencia casuista, fue en el XVII y en la práctica se prolonga durante la primera parte de la centuria siguiente. La declinación se hizo visible a medida que se fueron modificando los criterios hasta entonces dominantes entre los juristas. La nueva literatura postulaba un orden jurídico exclusivamente asentado sobre leyes abarcadoras y reunidas en cuerpos normativos organizados según pautas racionales, que hacían innecesaria la subsistencia de los antiguos mecanismos de aplicación normativa. En la última etapa es dable observar una acentuación del giro negativo del vocablo en algunos textos legales, es decir para expresar que no se debía admitir ni recurrir, bajo ninguna forma a esta figura. Pero aún en esa época hay muestras de su utilización, según veremos. El recelo, cuando no el repudio, hacia esos instrumentos arrastró a la disimulación que se desvaneció hasta desaparecer del cosmos jurídico en el siglo XIX. Ello ocurrió sin mayor notoriedad en contraste con las incisivas censuras que soportaron otras figuras o fuentes del antiguo orden, como la costumbre, la equidad o el arbitrio judicial.

13 Sobre esto remito a mi obra citada Casuismo y Sistema, pp. 83 ss. 


\section{El discurso jurídico de Solórzano}

Dentro de la literatura jurídica indiana el material más sustancioso para examinar esta figura se encuentra, sin duda, en la Política Indiana de Juan de Solórzano Pereira. ${ }^{14}$ La obra se publicó en el momento de esplendor de la jurisprudencia casuista, adquirió bien pronto el valor de fuente directiva del Derecho indiano ${ }^{15}$ y tuvo un largo reinado intelectual, agotado solo con el ocaso del régimen indiano. Los juristas la invocaban en cuestiones precisas y la misma Corona se atenía a sus opiniones. La Política Indiana trasciende así a su autor y se convierte en un reconocido repertorio con aplicación jurídica. Para nuestros fines es útil saber que Solórzano era atento y perspicaz observador de la vida indiana, experto en sus posibilidades y límites, y conocedor del Derecho de su época. Parece obvio decir que en esto descansa buena parte de su gloria jurídica.

En estas condiciones, la incorporación de nuestra figura en el discurso solorciano es altamente sugestiva. El vocablo aparece diseminado a lo largo de la obra a propósito de diversos temas, no siempre usado en forma asertiva y sujeto a la modalidad discursiva casuista de la época. No cabe buscar definiciones o juicios generales. Solo es posible captar su presencia dentro de la argumentación desenvuelta a propósito de cuestiones concretas. El espacio que esta figura tenía en el tejido solorciano era reducido e inconstante y sólo aparecía cuando las circunstancias lo requerían.

Aunque Solórzano, como buen casuista, huía de las definiciones o juicios de carácter general, es posible detectar un pasaje del texto donde explaya su idea nuclear acerca de la disimulación. Está asentado cuando trata de las personas a quienes pueden darse encomiendas y de las cuestiones que al respecto se suscitan, en un capítulo donde finaliza dejando dudas e interrogantes sin respuesta. En ese marco aparece este pasaje central: "Pero en tales materias, y en Provincias tan remotas y donde tan fácilmente se truecan las cosas, muchas dispensaciones, y disimulaciones pide la ocurrencia, y congruencia de los negocios y la diferencia de los tiempos y las personas, y la prudencia consiste en la connivencia, que es, no lo querer apurar todo, ni

14 Juan de Solórzano Pereira, Política Indiana (1647). Ed. consultada, Madrid, 1776.

15 Víctor TAu Anzoátegui, "La doctrina de los autores como fuente del Derecho castellanoindiano", en Revista de Historia del Derecho, núm. 17, Buenos Aires, 1989, pp. 351-408. Reproducido en este vol. (V). 
llevarlo por el sumo rigor del derecho, haciéndonos desatendidos de sus puntos, y tolerando semejantes transgresiones algunas veces". ${ }^{\mathbf{1 6}}$ Aunque el contexto de donde se extrae este pasaje no permite darle indebida ampliación y, aún más, es necesario interpretarlo de modo restringido para solo las materias tratadas en ese capítulo, estimo con todo que conviene tenerlo en cuenta a propósito de las otras referencias al vocablo que encontramos en la obra.

El pasaje transcripto tiene particular entramado. Se utilizan allí enlazados cuatro vocablos claves: dispensación, disimulación, tolerancia y connivencia. No es ciertamente una casualidad ni se trata de un párrafo deslizado al correr de la pluma. Esconde mucha sustancia y conocimiento de la realidad indiana. Se vuelca en el mismo una larga observación y experiencia acumulada como ministro de la Corona en América y en España.

Solórzano establecía que las dispensaciones y disimulaciones se hacían necesarias cuando el jurista enfrentaba negocios que debía resolver conforme a la ocasión y conveniencia, atendiendo a la diferencia de los tiempos, lugares y personas. Esta situación se presentaba de manera particular dentro del orden indiano, dados los factores de distancia - "Provincias tan remotas" - y mutabilidad - "donde tan fácilmente se truecan las cosas". Este razonamiento, breve y contundente, lo llevaba a afirmar nada menos que "la prudencia consiste en la connivencia”, es decir, disimular o tolerar las transgresiones cometidas por los subordinados contra las reglas o las leyes bajo las cuales viven. El mismo Solórzano explica: no aplicar "el sumo rigor del derecho", la letra implacable y tolerar "semejantes transgresiones algunas veces". De este modo Solórzano da categoría jurídica a la figura que venimos considerando. Si bien su aceptación es franca, siempre tiene carácter de excepción. No es complaciente en su utilización y en numerosas ocasiones podemos encontrar dentro de la obra muestras de esos límites, que atajan su uso abusivo.

El lector atento de Política Indiana puede registrar más de 50 veces la utilización del vocablo disimular y también el de tolerar, casi siempre en sentido jurídico. De tal modo aquel pasaje central se afirma como el núcleo conceptual que le sirve para diversas aplicaciones en el desarrollo de su discurso. Si bien el vocablo tolerancia acompaña a disimulación - a veces se citan ambos unidos - no parece alcanzar en la argumentación solorciana la dis- 
tinción y fuerza diferenciadora suficiente para contrastarlo con nuestra figura, que es finalmente la que alcanza una consistencia jurídica propia. El uso de ciertas expresiones, como la de "por vía de disimulación", dando a entender la existencia de un cauce jurídico admitido, refuerza esta impresión. ${ }^{\mathbf{1 7}}$

La disimulación tiene un origen transgresor. De este modo se introduce en el orden jurídico produciendo hechos contrarios a las normas existentes. El jurista casuista - como Solórzano - atento al devenir constante de casos o situaciones diferentes no se inmuta ante estos quebramientos, pues los reconoce como propios de la vida jurídica. Los observa e incorpora a su elaboración. Algunos de esos hechos resultan inadmisibles porque chocan frontalmente con los pilares del orden jurídico. Son rechazados. Otros, en cambio, con el mismo origen son admitidos y asimilados. Su admisión - producto de una elaboración selectiva - aparece forzada por las circunstancias y está a veces impregnada de cierto disgusto, pero se impone bajo la idea de que es más útil y conveniente la aceptación de esa transgresión que una rigurosa aplicación normativa.

La figura actúa pues a contrapelo del orden normativo establecido. El jurista no la repudia, sino que la admite en el entendimiento de que el Derecho no es una creación abstracta emanada puramente de la mente del jurista o de la voluntad del legislador, sino que constituye un complejo entramado socio-jurídico. Este es, a mi juicio, el perfil más interesante de la figura a la que hoy nos aproximamos.

La aceptación del jurista, sin embargo, es restringida. Se acepta a la disimulación como elemento que consolida el pasado, que cabe respetar, pero no puede invocarse como derecho asentado para el futuro, como ocurre con la costumbre. ${ }^{18}$ Además solo tiene carácter local y no puede extenderse a otras partes donde no se hubiese introducido. ${ }^{19}$ Solórzano, tratando de las encomiendas, cita a San Agustín y otros autores, para afirmar ese matiz restringido al expresar que "cuando ya algún vicio se ha hecho costumbre en alguna República, y no se puede quitar del todo sin peligro, porque si se quitase, se podría recelar que los súbditos prorrumpiesen a cosas de mayor daño, es sano y prudente consejo, el tolerar y disimular, mejorando las cosas en los que el estado de ellos buenamente lo permitiere". ${ }^{20}$ Bien se registra

17 Ídem, III, XVIII, 1; y III, XXIII, 14.

18 Ídem, II, IX, 31; II, XII, 12; IV, XXI, 13; y VI, XII, 10.

19 Ídem, III, XXIV, 18-23.

20 Ídem, III, I, 20. 
aquí "el tolerar y disimular" como actitud prudente y conveniente del hombre de gobierno o de justicia ante "algún vicio... hecho costumbre", pero al mismo tiempo como postura que revela insatisfacción y ansiedad por mejorar las cosas en el futuro. ${ }^{21}$ Ello forma parte del arte de gobierno, como el mismo Solórzano lo apunta en cierto pasaje, al sostener la conveniencia de que los virreyes y gobernadores, en resguardo de la autoridad que ejercen, deben "a veces disimular algo" por no "turbar y embarazar todo..."22 Y aplica este criterio cuando se ocupa del gobierno de las órdenes religiosas. Sostiene que los virreyes, gobernadores y audiencias no deben entrometerse en ese ámbito y deben ser recatados en admitir los recursos de los religiosos contra sus prelados y visitadores. Le parece más acertado "disimular o tolerar" si sufriesen esos religiosos algunas penalidades y vejaciones aunque fuesen injustas, antes que "aflojar y relajar el nervio de la disciplina Monástica". ${ }^{23}$

Ahora bien, en esa sutil tarea de escoger y autorizar disimulaciones, había algunas que eran rechazadas. La disimulación se convierte así en actitud o conducta reprobada y este matiz es verificable, con cierta frecuencia, en Política Indiana, a veces recogiendo disposiciones reales. Valga de ejemplo aquella referida al Real Patronato, en la cual se mandaba ejecutar lo dispuesto "sin embargo de que en el decurso del tiempo y pretensiones de los Prelados y Doctrineros se haya disimulado, o introducido otra costumbre, a que por ningún caso se ha de dar lugar en ninguna manera". ${ }^{24}$ Hay aquí un curioso frente común contra la costumbre y la disimulación, expresiva del rango que se le concedía.

Dentro de la Política Indiana pueden visualizarse otros modos en que operaba la disimulación. Ya aparece como elemento que templa el rigor de ciertas obligaciones y prohibiciones, ${ }^{25}$ ya como alternativa de permisión o concesión para destacar situaciones en que se permite o disimula, se concede o disimula, se manda o tolera, etc. ${ }^{\mathbf{2 6}}$ Me detengo solo ahora en el análisis de una interesante variante tratada por Solórzano. Es a raíz de la cuestión acerca

21 Otras referencias en ídem, II, X, 13; III, V, 30; y III, VI, 41.

22 Ídem, III, VIII, 16.

23 Ídem, IV, XXVI, 21.

24 Ídem, IV, XVII, 13 (Recopilación de Leyes de Indias, I, XV, 2 y 6). Otras: I, XII, 28 y 37; II, IV, 4 y 21; III, VI, 68; III, VII, 36; V, II, 28; V, XI, 31 y 33; y VI, II, 31.

25 Véase ídem, II, XXII, 28; II, XXV, 36; y III, XXV, 54.

26 Por ejemplo: para disimular, ídem, II, IV, 34; III, IV, 13; III, XXIII, I; y IV, VII, 21. Para tolerar: ídem, II, VII, 64; II, VIII, I; y II, XVI, 71. 
de cómo debían actuar los virreyes y gobernadores en la provisión de las encomiendas, concediéndolas a las personas beneméritas como justa retribución a sus servicios, conforme a muchas reales cédulas. Sin embargo, apunta Solórzano, pocos o ninguno de aquellos ministros han procedido de tal forma. Esto puede llevar a considerar derogadas dichas cédulas. Sostiene nuestro autor que para que esto ocurriera hubiera sido necesario contar con el conocimiento y tolerancia del rey que las despachó y además que se diesen "casos de muchas transgresiones disimuladas". Para desechar esta hipótesis, alega Solórzano la frecuente reiteración de aquellas cédulas. ${ }^{27}$ De este modo la disimulación aparece ocupando un papel determinante en la vigencia del orden jurídico, explicándose así la función que en este juego tiene la repetición de las órdenes reales para impedir que, precisamente por la vía de disimulación o de otros recursos, caigan los efectos de los anteriores mandatos.

Aunque en la obra de Solórzano pueden faltar precisiones - como las diferencias conceptuales entre disimulación, tolerancia y dispensa -, lo cierto es que ofrece una riqueza y variedad de ocasiones en que nuestra figura aparece en distintas posturas según sean los temas y situaciones allí considerados. Aquella ausencia de precisiones le permite al autor manejar con más libertad la invocación a la disimulación, que opera así como elemento dentro del conjunto de argumentos y razones que permiten establecer puntos de conexión entre el nivel normativo y el campo de aplicación del Derecho.

\section{Entre textos legales}

La disimulación aparece con alguna frecuencia en los textos legales, ya en los que provienen de autoridades peninsulares, ya en los expedidos en las mismas provincias indianas. En estos textos no he encontrado la misma diversidad de usos que puede observarse, por ejemplo, en la Política Indiana, según se ha visto, pero no descarto que una indagación más intensiva pueda modificar esta apreciación actual.

El uso más frecuente observado en estos textos es de índole negativa, es decir advirtiendo a autoridades o particulares sobre conductas que no debían seguirse o era menester condenar. A las autoridades repetidamente se les indicaba que no permitiesen, tolerasen ni disimulasen actos contrarios a las órdenes reales dadas en distintas materias. Con todo, aun usada la figura 
en este sentido, se destaca su presencia, desde el momento en que aparece reconocida como un elemento actuante en la vida jurídica.

Donde la admisión de la disimulación en la legislación indiana ha sido más patente es en materia de sucesión de encomiendas. No se trata solo de considerar la importancia de la materia tratada - que es innecesario remarcar - sino de atender a la nitidez con que es usada nuestra figura. No en balde, Altamira sostuvo que estas leyes indianas expresan lo que él denominó "la teoría civil de la disimulación”.

La cuestión que pasamos a considerar se suscitó en Nueva España, sin extenderse a otras provincias indianas. Las encomiendas habían sido, como norma general, concedidas por dos vidas. A mediados del siglo XVI empezaron a registrarse una serie de casos que debieron contemplarse para evitar que los titulares de encomiendas y sus sucesores sufrieran la pérdida del beneficio al cabo de la segunda vida y así se fueron admitiendo repartimientos en tercera vida. La insistencia de los encomenderos no se detuvo allí y las peticiones se repitieron para prorrogar el beneficio por una cuarta vida. Las respuestas reales fueron dilatorias y mientras mantenía la disimulación en la tercera vida, sostenía que lo relativo a la cuarta vida estaba en consideración. Por entonces, se había planteado una nueva petición más avanzada aún: la perpetuidad de las encomiendas. Después de una disposición real de 1597 en contra de las pretensiones de los encomenderos, una década después se resuelve finalmente disimular la cuarta vida. ${ }^{\mathbf{2 8}}$

Las sucesivas disposiciones reales dictadas a partir de 1555 fueron recogidas y condensadas en la Recopilación de 1680. Bien vale la transcripción de la parte pertinente del texto recopilado: "Consideradas las justas causas, que concurrieron para gratificar y remunerar los servicios, que en las Provincias de Nueva España hicieron los primeros descubridores y pobladores, se les hizo merced de repartimientos y encomiendas en primera y segunda vida. $Y$ porque se iban acabando por incorporación en nuestra Real Corona, y sus hijos y descendientes quedaban muy pobres, y fenecida la memoria de los servicios de sus pasados, se mandó disimular en la tercera, y después se les hizo merced de disimular en la cuarta. Mandamos que así se guarde y cumpla.... Vuelve a utilizarse el vocablo en otra ley siguiente sobre la materia: "Y mandamos, que en lo tocante a la sucesión de los maridos a las mujeres, y de

28 Silvio A. Zavala, La encomienda indiana, $2^{\mathrm{a}}$ ed., México, 1973, especialmente pp. 589 y 608 ss. 
las mujeres a los maridos, después de la segunda vida, se disimule en la Nueva España por la forma contenida en las leyes de este título". ${ }^{29}$

He preferido utilizar los textos recopilados y no las leyes originales, precisamente para advertir como se mantenía el uso de la disimulación empleada en disposiciones que habían sido expedidas aproximadamente un siglo atrás; y además como se presentaba en las mismas el orden de la cuestión dando una secuencia de los acontecimientos. Su inclusión en la Recopilación es el resultado de un cuidadoso proceso de selección. El vocablo aparece tres veces en estas dos leyes, sin que se usasen otros conexos o alternativos. Esto da a la disimulación un relieve propio, una fuerza de precepto, que se enfatiza aun más cuando se emplea la expresión "merced de disimular".

¿Por qué se acude a este vocablo en un asunto tan importante? Es evidente que para los juristas de entonces no parecía existir otro más adecuado para expresar la situación acontecida y la solución dada. Cuando se sigue la trama de la cuestión se advierte que se trataba de concesiones algo forzadas, dadas con carácter provisional, ante los apremiantes pedidos de los encomenderos novohispanos, pero que la materia estaba aun sin resolverse definitivamente, ya por que estuviese en estudio, ya porque se prefiriese postergar la decisión. Esta precariedad de la concesión dada casi en contrariedad a los deseos reales es lo que se quiere exteriorizar con el uso de este vocablo y no de otros que pudiesen dar más firmeza a la situación jurídica. Por eso no aparecen en el texto palabras como concesión, permisión, tolerancia, dispensa ni menos costumbre. Los redactores de esos documentos conocían bien, sin duda, el alcance de nuestra voz y el lugar que ocupaba en el cosmos jurídico. Era una pieza necesaria en la vida jurídica.

En esta misma línea es interesante introducirnos en otro ejemplo. Es el caso que se suscitó en el Buenos Aires de mediados del siglo XVIII a raíz de la recurrente presencia de portugueses entre la población porteña. El gobernador dispuso en 1742 su expulsión en cumplimiento de una real cédula expedida cuatro años antes. El Cabildo obtuvo la suspensión de la medida con respecto a los casados y avecindados. El gobernador dio cuenta al rey. Fue entonces cuando el fiscal del Consejo de Indias se expidió, en términos rigurosos, por la expulsión de los portugueses del puerto. El Consejo empero requirió opinión a don Juan Vazquez de Agüero, ministro de la Corona que 
había residido durante cinco años en Buenos Aires y se encontraba entonces en la Corte. En su dictamen analizó la situación de la ciudad y estableció la conveniencia de mantener a esos pobladores en razón de los servicios que prestaban, y a pesar de las prescripciones legales. El fiscal cedió entonces parcialmente en su rígida postura inicial y el Consejo decidió que sin seguirse "el absoluto disimulo" en la observancia de dichas cédulas reales, era conveniente adoptar medidas concretas en atención al caso y así dispuso que a los portugueses radicados con hijos desde algún tiempo atrás "se les disimule la permanencia sin molestarlos en su vecindario....” ${ }^{30}$ Nuevo ejemplo de uso necesario de la figura. Encajaba bien en esta situación que se vivía entre la norma rigurosa y la palpitante realidad.

\section{En el mundo literario}

Como es sabido, en las centurias centrales de la Edad Moderna el léxico jurídico penetraba en los textos literarios en general y aun en el habla corriente. El examen de un texto indiano de esa procedencia permite afinar más nuestra percepción sobre esta figura jurídica y verificar en un círculo de mayor alcance el uso y peculiaridades que tiene. A tal fin escogemos la obra dieciochesca del padre Pedro Lozano, Historia de las revoluciones de la provincia del Paraguay (1721-1735). ${ }^{31}$

Aunque el vocablo disimulación es libremente usado en el texto, intercalado en la prosa narrativa, resulta posible a través de frases o giros rescatar un sentido más o menos homogéneo que pueda conceptuarse. Así queda resaltada la disimulación como un instrumento de gobierno tanto divino como terrenal, que acompaña a la prudencia, pero que no siempre produce los efectos deseados, sobre todo cuando se practica con "ánimos viles". Veamos.

30 El expediente en Archivo General de Indias, Charcas 215.

31 Pedro Lozano, Historia de las revoluciones de la provincia del Paraguay (1721-1735), editada por la Junta de Historia Numismática Americana en Buenos Aires, 1905, en dos volúmenes. Los datos aquí recogidos me han sido generosamente ofrecidos por el doctor José M. Mariluz Urquijo. Sobre la vida y obra del padre jesuita Pedro Lozano (1697-1752) puede verse una breve noticia en Francisco Esteve Barba, Historiografía indiana, Madrid, 1964, pp. 580-583. Más amplia información en Guillermo Furlong S. J., Pedro Lozano y sus observaciones a Vargas (1759), Buenos Aires, 1959. Con posterioridad, la Academia Nacional de la Historia publicó el texto original de otra obra principal suya, Historia de la Conquista de las Provincias del Paraguay, Río de la Plata y Tucumán, con estudio preliminar de Ernesto J. A. Maeder, Buenos Aires, 2010, 2 volúmenes. 
Lozano le asigna origen divino: "Es el Señor justo vengador de las injurias hechas a sus sagrados ministros y aunque tal vez disimule por sus altísimos inescrutables juicios, esta no la quiso pasar sin ejemplar castigo". ${ }^{32}$ Es también virtud que practica el Príncipe: "Quisiera con prudente disimulo el buen Príncipe hacerse por entonces desentendido de los excesos perpetrados....”33 Asimismo lo hace el Prelado religioso: "Disimuló el prelado en este motivo porque atendía siempre en sus acciones y palabras a que el Rey nuestro Señor no perdiera aquella provincia." ${ }^{34} \mathrm{Y}$ hasta un gobernador disimuló en el cumplimiento de una orden virreinal "por no haber hallado para que se efectuase disposición en el ánimo de los regidores".

El vocablo se muestra como de doble filo. El disimulo es prudencia, ${ }^{36}$ es ocasión para meditar mejor la ejecución de algo, ${ }^{37}$ es "sano consejo" ${ }^{38} \mathrm{Se}$ sostiene en fin que es mejor disimular que exponer a que la justicia sea burlada. ${ }^{39}$ Pero a veces produce efectos contraproducentes y "abre camino para mayores precipicios...", ${ }^{\mathbf{4 0}}$ para "mayor insolencia" ${ }^{\mathbf{4 1}}$ y para dar "licencia de pecar y proseguir en sus excesos" ${ }^{\text {"2 }}$

Se puede observar a través de esta pequeña muestra de la obra de Lozano, ajena al estricto mundo jurídico, cómo los significados y usos del vocablo reconocen un cauce común. La acepción técnica de la voz que hemos afinado mediante el apoyo de fuentes jurídicas, se hace de uso generalizado en otro tipo de textos de época.

\section{Cuestiones abiertas}

La disimulación es más que un vocablo con cierto sentido jurídico. Integra una constelación de figuras e instituciones que interviene sutilmente en el proceso que entronca lo normativo y lo fáctico. Ocupa un rango inferior, casi

32 Ídem, t. I, p. 201.

33 Ídem, t. I, p. 266.

34 Ídem, t. I, p. 295.

35 Ídem, t. I, p. 381.

36 Ídem, t. I, p. 393 y t. II, p. 124.

37 Ídem, t. II, pp. 124 y 244.

38 Ídem, t. I, p. 269.

39 Ídem, t. I, p. 327.

40 Ídem, t. I, p. 90.

41 Ídem, t. I, p. 159.

42 Ídem, t. I, p. 366. 
el escalón más bajo que separa el nivel jurídico del que no lo es; o como dice Grossi, el límite más extremo del "sendero de la equidad". ${ }^{33}$

Tanto Lefebvre como Grossi, al ubicarla dentro del orden canónico, le dan categoría de institución. Sus referentes comparativos son la dispensa tácita, la tolerancia y el silencio. El primero de los autores citados señala que el ejercicio de la disimulación corresponde a un poder de jurisdicción o de administración y representa la abstención en la consideración de un acto que no puede impedir, o en la aplicación de una ley, pero sin modificar la situación anterior. La autoridad aparenta ignorar un hecho ilegal. Entraña una actitud pasiva del superior, generalmente secreta y provisional hasta que se pueda suprimir la situación irregular. No crea pues ningún derecho al inferior. La razón de esta institución - prosigue Lefebvre - es evitar el escándalo, contar con el tiempo necesario para adoptar una decisión o suprimir una costumbre particular intolerable. Disimular es cerrar los ojos sin aprobar, sin acordar una dispensa tácita ni simplemente tolerar. ${ }^{44}$ Lo que se elude - aclara Grossi - no es la norma, sino la aplicación rigurosa de la misma. $^{45}$

Estas finas elaboraciones de Lefebvre y Grossi, que revisten a la disimulación de cierta categoría jurídica en el Derecho canónico, resultan en principio aplicables a nuestro Derecho indiano, en donde la figura adquirió una expansión significativa, acorde con las exigencias del nuevo orden.

Así una situación que merece profundizarse es la que se planteaba en materia de actas de bautismo, cuando a veces se omitían datos importantes, aún a sabiendas, para ocultar el nombre de padres o madres. En un notable estudio social sobre la familia montevideana de fines del período hispano, Arturo Bentancur saca a relucir esta cuestión, que bien puede caer dentro de una práctica de la disimulación. Una buena cantidad de casos allí registrados muestra el uso de la expresión "hijo de padres no conocidos" o recurre a una supuesta condición de expósito o huérfano para ocultar una situación que no convenía declarar, al menos en ese momento. Para no dañar la condición del párvulo, en alguna ocasión el celebrante agregó esta manifestación propia: "me consta que sus padres son de lucido nacimiento y distinción y por justas

43 Grossi, L'ordine..., cit.

44 Lefebvre, "Dissimulation", cit.

45 Grossi, L'ordine..., cit. 
causas no se expresan". En otros casos, la declaración de ser "hijo natural" amenguaba y a veces rectificaba aquella primera afirmación. Con frecuencia, aquella situación se superó posteriormente por diversas vías de "legitimación”. El minucioso estudio llevado a cabo por el autor permite observar diferentes tramas de esa vida social que lleva a pensar en el interesante juego que tenía esta figura en un campo tan delicado como era el registro canónico de los nacimientos. ${ }^{46}$ Sin dejar de lado otras motivaciones o razones, la figura parecía operar como un mecanismo de protección del "honor de la mujer".

Es en las páginas de la Política Indiana donde se puede obtener, según vimos, la mejor imagen de esta figura en su vida indiana. Solórzano acude frecuentemente a ella y le da categoría jurídica. Una comparación entre esta obra y la Política de Bobadilla, por vía de ejemplo revelaría la apreciable diferencia de grado que tenía la disimulación entre Castilla e Indias. Esto se corrobora con las notables leyes en materia de sucesión de encomiendas dadas para Nueva España, donde la utilización de la figura aparece como recurso necesario y por otra parte consolidado, sobre todo cuando se incluye la expresión de "merced de disimulación". Sin salir de un terreno hipotético puede estimarse que la figura adquirió en el orbe indiano un lugar más destacado que en otros ordenamientos jurídicos del pasado y que, si bien la inspiración canónica que lo insufla y la vía castellana que lo impulsa son modelo y camino, respectivamente, en la configuración indiana se perciben elementos nuevos y originales.

La disimulación es aceptada con reticencia. De ahí que fuese frecuente prevenir sobre eventuales daños e inclusive encontrar en las normas cláusulas expresas ordenando no consentir en ella. Se trataba de un recurso extremo con vistas a evitar un mal mayor. Es que - dice Grossi - por esta vía se llega a establecer la desigualdad formal y el escándalo aparente del pecador 'tolerado' y del justo 'castigado', que no es fácil de entender. Dicho autor encuentra que es "la aplicación extremada" en el campo jurídico de la parábola evangélica del Buen Pastor que va en busca de la única oveja extraviada, mientras deja momentáneamente su rebaño. También en este sentido podría mencionarse otra parábola del mismo evangelista Lucas, sobre el festejado regreso a

46 Arturo A. Bentancur, La familia en el Río de la Plata a fines del período hispánico. Historias de la sociedad montevideana. Planeta, Montevideo 2011, pp. 364 yss. 
la casa paterna del hijo pródigo, ante el desconcierto e incomprensión del hermano mayor, el hijo justo.

Las referidas evocaciones bíblicas ayudan a comprender el alcance de ciertas actitudes y a percibir mejor el múltiple papel que cumplía esta figura. En este sentido valga como ejemplo, la opinión del virrey de Nueva España, Marqués de Cerralbo, cuando decía que los alcaldes mayores que violaban la prohibición de comerciar eran dignos de "disimulación piadosa", pues no podían sustentarse sin comerciar, pero en cambio merecían castigo los que no solo faltaban a la ley sino que imponían precios abusivos. ${ }^{47}$

Pese a estas aproximaciones quedan varias cuestiones abiertas que hacen al carácter de la figura, su trayectoria castellana e inserción en las Indias y, en fin, su fase de decadencia. Estas páginas no pretenden constituir una monografía concluida. En parte, por lo escurridizo del tema, cuya indagación minuciosa sería infinita. Pero también en buena parte porque la disimulación no es figura solitaria, sino que opera como uno de los engranajes existentes en el antiguo Derecho para aproximar la letra fría de la ley a las situaciones concretas. La articulación con otros elementos y el funcionamiento de esos mecanismos es aun materia que todavía conocemos escasamente. En una visión del Derecho indiano que intente superar el mero ordenamiento legal, éste es un punto de capital importancia. La disimulación es hilo de una trama, pero si lo seguimos con atención podremos ir conociendo mejor esa trama, que no es otra que la práctica social del Derecho. En esta indagación iushistoriadores e historiadores sociales tienen un buen camino por recorrer. ¿Pueden haber esfuerzos convergentes y diálogos abiertos?

47 Lewis Hanke, Los virreyes españoles en América durante el gobierno de la Casa e Austria. México, Madrid, 1977, t. III, p. 277. Este dato lo recoge José M. Mariluz Urqujo en El agente de la administración pública en Indias, Buenos Aires, 1998, p. 35. 



\section{El Abogado del Cabildo de Buenos Aires durante el Virreinato*}

Sumario: 1. Introducción - 2. Evolución de la función letrada - 3. Denominación y caracterización de la función - 4. Forma y tiempo de la designación - 5. Atribuciones. Deberes. Honores - 6. La retribución - 7. Epílogo

\section{Introducción}

A partir de la Baja Edad Media, cuando el gobierno de las comunidades políticas se hizo más complejo, fue destacándose, con perfil cada vez más

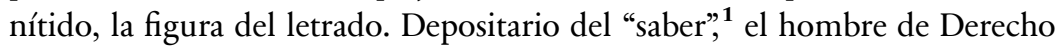
resultaba necesario en dos tareas muy apreciadas: la del consejo, para medir el alcance de una grave decisión; y la de la técnica jurídica adecuada para resolver las más diversas cuestiones concernientes al gobierno y la justicia.

La importancia del auxilio letrado se manifestó, ya en América, desde los mismos orígenes de la colonización, ${ }^{2}$ y adquirió particular relieve, entre nosotros, en el último cuarto del siglo XVIII, al crearse el Virreinato rioplatense, coincidiendo con el súbito surgimiento de una burocracia administrativa. $^{3}$

Aquellas dos tareas propias del letrado constituían las bases inexcusables de un buen ejercicio del gobierno y de la justicia. Así en las diferentes áreas de la administración aparecía el hombre de derecho, ya como funcionario

* Publicado en Academia Nacional de la Historia, Bicentenario del Virreinato del Río de la Plata, Buenos Aires, 1977, t. I, pp. 85-104.

1 José Antonio Maravall, "Los 'hombres de saber' o letrados y la formación de su conciencia estamental", en Estudios de Historia del pensamiento español, serie primera, $2^{\mathrm{a}}$ edición, Madrid, 1973, p. 355-389.

2 José M. Mariluz Urquijo, "El asesor letrado del Virreinato del Río de la Plata", en Revista de Historia del Derecho, núm. 3, Buenos Aires, 1975, p. 167-171.

3 Sobre este tema, veáse la obra de José M. Mariluz Urqujo, Orígenes de la burocracia rioplatense. La Secretaría del Virreinato, Buenos Aires, 1974. También del mismo autor, El agente de la Administración pública en Indias, Instituto Internacional de Historia del Derecho Indiano, Instituto de Investigaciones de Historia del Derecho, Buenos Aires, 1998. 
que decidía por sí - tales como los oidores, el teniente letrado, etc. -, ya como asesor de los altos funcionarios en los negocios a su cargo.

El consejo era un elemento clave en la estimación colectiva de la época. Decía Castillo de Bobadilla en su Política para Corregidores - obra de vastísima difusión y gran influencia en esos días - que "el gobierno de una República no consiste en muchas fuerzas sino en mucho y buen consejo para la útil dirección de todas las acciones".

Incitaba a corregidores, alcaldes y regidores a servirse de tenientes y asesores para determinar las causas. Recogía así Bobadilla una tradición literaria - enlazada con textos bíblicos y con las leyes alfonsíes - que enaltecía la importancia del consejo y del hombre de letras en el gobierno político. Ello le permitía afirmar que "después de la Fe y Religión, son las letras la cosa con que más los hombres se incitan y mueven a la virtud, a la paz, a la verdad, y justicia, y a todas las otras bondades, de cuantas hay en el mundo". ${ }^{4} \mathrm{La}$ voz consejero, del antiguo lenguaje, resultaba equivalente a finales del XVIII a la de asesor, según decía en 1792 Antonio Xavier Pérez y López en su Teatro de la legislación. ${ }^{5}$

Además de consejero, se reconocía en el letrado al hombre indicado para proporcionar la técnica más adecuada para plantear, argumentar, agitar e incluso elaborar las decisiones más disímiles, al punto de convertirlo en un auxiliar indispensable tanto en los asuntos de gobierno superior como en los más minúsculos de la administración y del ejercicio de la justicia cotidiana. La idea no estaba sólo arraigada en las grandes ciudades sino que se extendía aun a los pueblos de campaña. Así nos encontramos que, hacia fines del siglo, para eximir de su cargo al alcalde de la hermandad electo, el cura de la Parroquia de la Exaltación de la Cruz no hallaba mejor argumento para alegar que el designado, entre otros impedimentos "es un Pobre que no tiene con que costear escribiente, Abogado, y otras cosas que son necesarias para ejercer debidamente el referido cargo". ${ }^{6}$

4 [Jerónimo] Castillo de Bobadilla, Política para Corregidores y Señores de Vasallos..., lib. II, cap.VI, núm. 1 (Ed. Madrid, 1759, I, 327); I, XII, n 5-8 (I, 151-152), y I, IX y X (I, 110-122 y 141).

5 Antonio Xavier Pérez y López, Teatro de la legislación universal de España e Indias, t. IV, p. 323, Madrid, 1792. Recuerda esta circunstancia Mariluz Urquijo, "El asesor letrado...", en donde se ocupa del tema del consejo (165-167).

6 Archivo General de la Nación, Archivo Cabildo (en adelante AGN, AC) 1797-1798, IX, 19.4.11, fs. $153-155$. 
El objeto de este trabajo es advertir acerca de la relevancia que, dentro de las actividades capitulares, tuvo la función letrada, tanto en el asesoramiento como en las demás tareas propias del oficio. ${ }^{7}$ De ahí el afán, evidenciado tanto en los proyectos como en los hechos, por obtener un abogado o asesor, que tuviera a su cargo la misión de aconsejar y dirigir al Cabildo dentro de los carriles jurídicos. El tema abordado se refiere tan sólo a la función letrada con relación al Ayuntamiento propiamente dicho y excluye el estudio del asesoramiento individual que recibían determinados funcionarios capitulares - alcaldes, síndicos, procurador general, defensor de pobres, etc. -, aun cuando en algunos casos ambos aspectos aparecieran estrechamente vinculados.

No puede desatenderse el contexto en que se desenvolvió esta función letrada que estudiamos. Al crearse el Virreinato rioplatense y establecerse la capital en Buenos Aires, el Cabildo de la ciudad alcanzó, como es natural, su máxima jerarquía. Pero en realidad los continuos sinsabores que se fueron sucediendo le impidieron gozar de los halagos propios de tan empinada posición. A una generalizada tendencia de menoscabo del poder político de los cabildos, ya reflejada desde un siglo atrás, se sumó la intensa presión de la nueva burocracia virreinal, que desde distintos ángulos - funcional, jurisdiccional, protocolar o financiero - fue dificultando la vida del Ayuntamiento. El Cabildo se encontró muchas veces enfrentado con los órganos superiores de gobierno o con algunos de sus hombres claves: Virrey, Intendente y Audiencia. A veces, los desaires públicos y las imposiciones de las autoridades motivaron la amarga queja de los capitulares, los que al mismo tiempo, entre atemorizados y resignados, aceptaban una realidad insoslayable.

Sometido en sus decisiones a la aprobación superior, usurpada a veces su jurisdicción y atribuciones, y privado del control de sus finanzas, el Cabildo fue perdiendo paulatinamente aquellos elementos propios del poder que lo habían caracterizado nítidamente en la organización indiana de los primeros siglos. La gloriosa actuación que le cupo al Cabildo en la defensa de la

7 Este tema ha pasado en general desapercibido para los autores. RicARdo ZorraQuín Becú, en su estudio sobre los cabildos argentinos, refiere brevemente la existencia del "Abogado del Cabildo" (La organización política argentina en el período hispánico, Buenos Aires, 1959, pp. 345-346). También lo trata Javier González Echenique, Los estudios jurídicos y la abogacía en el Reino de Chile, Santiago [1954], pp. 291-299 y 338-342. 
ciudad en 1806 y 1807, frente al invasor británico, aunque le dio nuevo vigor, no alcanzó con todo a borrar aquellas huellas y sobre todo a torcer un destino dado por circunstancias que escapaban al ámbito de actuación de un solo ayuntamiento y de una circunstancia ocasional. ${ }^{\mathbf{8}}$

El consejo letrado, en su más amplia comprensión, estuvo presente en el Cabildo, como en los demás órganos del gobierno indiano durante esta época, aunque no siempre apareciera a primera vista en la plantilla de funcionarios, con la designación específica. La obtención de un letrado que desempeñase en forma permanente esta función constituyó una aspiración que a través de este tercio de siglo experimentó diversas contingencias, como veremos, y que sólo se alcanzó a concretar ya en los días de la Revolución de Mayo. Como las tentativas fueron repetidas e incluso se alcanzó a concretar alguna, resulta posible, a través del cuadro de necesidades expuesto y de la misma experiencia recogida, caracterizar a esta función y señalar al menos el propósito que animaba a los capitulares al abogar por su erección definitiva.

Luego de mostrar la evolución general de la función en la dinámica institucional, he de ocuparme por separado de destacar algunos aspectos propios de la misma, tanto en la faz proyectista como en los resultados que dejó su aplicación.

Como veremos enseguida, en la vida capitular se observan algunas oscilaciones, aparentemente muy pronunciadas, en lo que hace a la presencia del funcionario letrado permanente. Así durante este largo tercio de siglo virreinal, hubo períodos con activa participación del letrado y otros en que éste desaparecía casi totalmente. Del mismo modo, a urgentes pedidos a favor de la creación de un cargo letrado, se seguían luego prolongados silencios.

Resulta difícil explicar documentalmente estos pronunciados desniveles, pero pueden indicarse algunas hipótesis originadas en huellas o rastros que se desprenden del análisis de los testimonios. Se percibe fácilmente que el Cabildo no actuó nunca huérfano de todo auxilio letrado. Cuando no tuvo un letrado especialmente designado, recurrió ocasionalmente al consejo pro-

8 Sobre esto veáse ZorraQuín Becú, “Abogado...”, cit., pp. 358-359. Me he ocupado también incidentalmente de este aspecto en "La costumbre en el derecho indiano del siglo XVIII. La doctrina jurídica y la praxis rioplatense a través de los cabildos”, en Memoria del IV Congreso del Instituto Internacional de Historia del Derecho Indiano, México, 1976, reproducido en Víctor Tau Anzoátegui, El poder de la costumbre, Buenos Aires, 2001, pp. 261-265. 
fesional o encomendó a un abogado la atención de determinados negocios o expedientes. Esta forma de servicios se dio con bastante frecuencia a través de las constancias que pueden recogerse en las actas capitulares y en el archivo del Ayuntamiento. Pero aun faltando estos datos debemos suponer que el consejo letrado se canalizaba por otras vías, no necesariamente registradas en todos los casos en la documentación: por medio de los letrados que asesoraban a los alcaldes o al síndico procurador general; ${ }^{9}$ por letrados que se desempeñaban como regidores; ${ }^{10}$ por algún letrado que oficiaba de escribano del cuerpo; ${ }^{11}$ o por abogados que aconsejaban particularmente a los regidores. $^{12}$

En esa evolución en pos del establecimiento de un funcionario letrado, cabe señalar algunas etapas. Una primera, se extiende hasta fines de 1783, en que no existió un cargo letrado específico. La importante resolución del gobernador-intendente Sanz, del 31 de diciembre de ese año, abrió un nuevo período que se extiende por cuatro años, durante el cual la figura del Asesor o del Abogado ocupa un lugar de relieve en la composición capitular. Pero a esa etapa sucede otra de sugestivo silencio en torno del Asesor que ha desaparecido como función. En 1792, nuevamente se predica la necesidad, urgente, nerviosamente expuesta, de tal funcionario. Pero ni entonces ni en 1795, en que se vuelve sobre el asunto, nada se concreta. Largos años transcurren casi quince - sin que se manifieste la necesidad de contar con un cargo de Abogado o Asesor capitular. Sólo en 1810 vuelve a agitarse el asunto y esta vez si, con éxito, ya que se concreta al año siguiente. Me ocuparé enseguida de registrar pormenorizadamente dicha evolución, para luego analizar los rasgos fundamentales de esa función.

\section{Evolución de la función letrada}

Durante la primera mitad del XVIII fue muy escaso el número de abogados radicados en Buenos Aires. Mientras en algunos años del primer cuarto no había ninguno y en caso necesario debía consultarse a un letrado residente

9 AGN, AC., 1776, IX.19.2.11, fs. 12; Archivo General de la Nación, Acuerdos del extinguido Cabildo de Buenos Aires (en adelante Acuerdos), Serie $3^{\mathrm{a}}$, t. X, pp. 135 y 151-152.

10 Acuerdos, $3^{\text {a }}$, t. XI, pp. 188-189.

11 Ídem, $4^{\text {a }}$, t. II, p. 686.

12 Ídem, $3^{\text {a }}$, t. X, p. 135.

El Abogado del Cabildo de Buenos Aires durante el Virreinato 
en otro lugar, ${ }^{\mathbf{1 3}}$ ya en el segundo cuarto de la centuria empezó a modificarse esta situación de orfandad profesional. El Cabildo, en distintas oportunidades, reveló su interés por utilizar los servicios de letrados y en 1729 intentó designar un asesor permanente. El proyecto fracasó debido a que quien había concitado la atención de los capitulares era el licenciado Juan Manuel de Arce y Sotomayor, ya designado asesor general de gobierno. Arce, previendo una natural incompatibilidad, rehusó el cargo, aunque aceptó ejercer el asesoramiento en aquellos casos en que no se comprometiera su necesaria intervención como asesor general de gobierno. ${ }^{\mathbf{1 4}}$

Años después, en 1734, el Cabildo designó como asesor al licenciado Alonso Pastor, nombramiento que volvió a repetirse diez años más tarde, sin que su actuación fuera ininterrumpida. A partir de este segundo nombramiento, la actividad de Pastor fue permanente pues asistía a los acuerdos y firmaba las actas. Pero a comienzos de 1745 se dispuso el cese del asesor, ante la falta de recursos para mantener el cargo. ${ }^{15}$ De ahí en adelante, por un largo período, el Ayuntamiento adoptó el criterio de designar tan sólo asesores ocasionales, cuando la gravedad del asunto así lo requería. ${ }^{\mathbf{1 6}}$

Sin embargo, las ventajas que ofrecía un asesor permanente se palpaba en el seno del mismo Cabildo, como lo dejaba entrever el Cuerpo en 1763 a raíz de que el doctor Antonio de Aldao pretendía excusarse de ejercer el cargo de regidor. En esta oportunidad el Cabildo sostuvo que la incorporación del doctor Aldao era muy conveniente porque "con su dictamen podrá instruir a este Ilustre Cuerpo, en los puntos de derecho de que carece su inteligencia por no ser profesores de esta facultad". ${ }^{\mathbf{1 7}}$

La posibilidad de contar con un mejor punto de apoyo que la mera consulta ocasional, fue seguramente una de las razones que hizo recurrir, años después, al consejo de los asesores letrados de los alcaldes ordinarios. ${ }^{\mathbf{1 8}}$

13 Ídem, 2 $2^{\text {a }, ~ t . ~ I, ~ p p . ~ 637-638 ; ~ t . ~ I I, ~ p . ~ 262, ~ y ~ t . ~ V, ~ p . ~} 536$.

14 Ídem, $2^{\text {a }}$, t. VI, pp. 57, 69, 78-89, 98, 102-104 y 108. Sobre este aspecto, véase también Mariluz Urquijo, “El asesor...”, cit., pp. 175-176.

15 Acuerdos, 2a, t.VII, pp. 107 y 109, 145-147; t.VIII, pp. 517 yss.; y t. IX, p. 20.

16 Ídem, $2^{\text {a }}$, t. IX, p. 610; $3^{\text {a }}$, t. I, pp. 110, 112-113, 186, 296, 320, 350 y 441; t. II, pp. 90, 127, $312,326,337,341,344,363,381,388,500,505,507-508$ y 537; t. III, 120, 469, 472-473, 477-478, 481 y 647-648; t. IV, pp. 174, 197, 254; y t.V, pp. 17, 23, 27-28, 68, 214, 551, 554,569 y 611 .

17 Ídem, $3^{\mathrm{a}}$, t. III, p. 120.

18 Ídem, $3^{\text {a }}$, t. IV, p. 689. 
Esta práctica, observada en los primeros años de la década del setenta, fue ratificada por el gobernador Juan José de Vértiz el 5 de enero de 1776, al dictar el auto confirmatorio de las elecciones capitulares. Allí estableció que los alcaldes ordinarios consultaran a sus asesores letrados, además de sus propias causas, "siempre que en el Cabildo se ofrezca algún asunto grave y para cuya resolución no pueden tener los individuos que lo componen, un bastante conocimiento por su distinta profesión.... ${ }^{19}$

Este criterio, oficializado por Vértiz, estaba llamado a tener repercusión en el futuro. Es posible que haya sido observado en los años siguientes, aunque sin desechar el sistema de consultas ocasionales a otros letrados. Ese principio volvió a manifestarse en la resolución dictada por el gobernador intendente Francisco de Paula Sanz el 31 de diciembre de 1783, al establecer un Asesor único para el Cabildo y los alcaldes. Fundaba la determinación en "la necesidad que imponen las leyes para que en todas las deliberaciones, especialmente concernientes al bien público se proceda con consejo.... La designación debía hacerla el propio Cabildo en el acto de practicar las elecciones anuales. Así fue como, al día siguiente, se designó al doctor José Vicente Carranzio, ${ }^{20}$ quien alcanzó a desempeñarse en tal cargo durante un año y nueve meses.

El 17 de diciembre de 1784 el alcalde de primer voto, don Francisco Antonio de Escalada, propuso "una Nueva Planta" para el Cabildo, dotándola de los regidores y funcionarios necesarios, acorde con la importancia que correspondía a un ayuntamiento ubicado en la capital del Virreinato. Entre las innovaciones propuestas, se destacaba la de incorporar un "Abogado Asesor", perpetuo, con dedicación exclusiva a las tareas propias del ayuntamiento, sin compartir la función con la asesoría de los alcaldes en material judicial. El mismo doctor Carranzio era sugerido para desempeñarse en el nuevo cargo. El Cabildo aprobó el proyecto, pero el Gobernador Intendente, ante la proximidad de las elecciones capitulares del 1 de enero, dispuso que, hasta que se expidiesen las providencias correspondientes para dar efectividad a la "Nueva Planta", las elecciones se hicieran en la misma forma, sin alterar tampoco en lo relativo al Asesor, debiendo subsistir el nombrado. ${ }^{21}$

19 AGN, AC., 1776, IX.19.2.11, fs. 12.

20 AGN, AC., 1780-1783, IX.19.3.2, fs. 458; Acuerdos, 33 , t. VII, pp. 281-282 y 289.

21 Acuerdos, $3^{\text {a }}$, t. VII, pp. 431-438, 445 y 446. La nota de Sanz en AGN, AC., 1784, IX.19.3.3, f. 216. 
Pocos meses después, el Cabildo volvió a insistir. El nuevo alcalde de primer voto, José Antonio Ibáñez, sostenía el 18 de junio de 1785 que urgía una solución por parte del gobierno, mucho más después de la reciente disposición virreinal por la cual las representaciones del síndico procurador llevarían la firma del Abogado de la Ciudad. ${ }^{22}$ La situación se hizo ya insostenible cuando muy poco después, el nuevo reglamento sobre administración de los propios y arbitrios suspendió el sueldo que gozaba el Asesor Carranzio, por lo que el Cabildo entendió que su designación había caducado. Fue entonces cuando aprovechó la situación para dar principio de ejecución a la "Nueva Planta" que tanto se dilataba en su aprobación. El 11 de octubre el alcalde Ibáñez decía que el ayuntamiento no tenía "Asesor, ni menos Abogado" y que "es visible la necesidad tenga un Abogado con quien hacer las consultas que se ofrezcan, y defender cuantos expedientes se hallan pendientes y nuevamente se soliciten en beneficio de la Ciudad". De tal manera, acordaron los capitulares nombrar al mismo doctor Carranzio sin límite de tiempo como "Abogado de esta M.I. Ciudad" ${ }^{23}$ El gobernador intendente aprobó el nombramiento. ${ }^{24}$

Esta creación no contaba empero con un sólido respaldo financiero, pues la retribución del cargo se atendería provisionalmente en forma extraordinaria, con la reserva de establecer luego una renta anual proveniente de los Propios y Arbitrios. ${ }^{25}$ La nueva situación se contempló en el presupuesto anual que, a fines de 1785, preparó el regidor decano Gregorio Ramos. Al hacerlo, Ramos no se limitaba a fijar la asignación anual, sino que establecía algunas de las características del cargo de "Abogado de este Ilustre Cabildo", como lo veremos más adelante. ${ }^{\mathbf{2 6}}$

La experiencia recogida no fue desafortunada si nos atenemos a que el Cabildo sostenía, a fines del año siguiente, que el cargo de "Abogado de la Ciudad" debía mantenerse "porque es esencial este individuo para un Cuerpo como éste en que frecuentemente se tratan negocios de entidad, y se

22 Acuerdos, $3^{\mathrm{a}}$, t. VII, pp. 534-535.

23 Ídem, pp. 590-591.

24 Ídem, pp. 615 y 618-619.

25 Ídem, pp. 590-591.

26 AGN, AC., 1785, IX.19.3.4, f. 178. 
agitan de la misma manera". ${ }^{27}$ La necesidad de contar con el auxilio letrado era tal que, para prevenir sus posibles ausencias, se proponía que lo suplieran los Asesores de los alcaldes. ${ }^{28}$

Un incidente personal vino a interrumpir esta exitosa experiencia. A principios de 1787, el doctor Carranzio se sintió agraviado por el procurador síndico general don Agustín Antonio de Erezcano, quien durante una sesión capitular, al tiempo de hablar aquél, le dijo que "dejase que los Señores Regidores resolviesen lo que tuviesen por conveniente en el punto de que se estaba tratando", dando con ello la impresión de que el Abogado quería imponer sus propios puntos de vista. La reacción de Carranzio fue, al parecer, inmediata, abandonando la atención de los asuntos capitulares, al punto que hacia fines de 1787 decía que "en todo este año no daba plumada alguna en asunto de este Cabildo". Aun cuando el Ayuntamiento trató de suavizar este incidente y ratificó su confianza en Carranzio, éste se empecinó en obtener una satisfacción personal del Síndico Procurador. El asunto fue llevado ante el Gobernador Intendente, y aunque Carranzio recibió amplia reparación a través de los testimonios ofrecidos por varios capitulares, no volvió a ejercer su cargo de Abogado del Cabildo. ${ }^{29}$

Este ingrato incidente tuvo insospechadas derivaciones, pues a partir de entonces, y por distintas razones, el Cabildo de Buenos Aires no volvió a tener otro Abogado, con las características señaladas, durante toda la época virreinal, aun cuando fueron varios los intentos por designarlos.

Un prolongado silencio sobre la materia cubrió casi los cinco años siguientes, hasta que en octubre de 1792 se acordó hacer presente al virrey "la necesidad urgente que tiene este I. Cabildo de tener un Asesor para consultar, dirigir y hacer las representaciones en aquellos casos a que los Individuos de este I. Cabildo no alcanzan por ser laicos". Sin este auxilio, agregaba,

se ven sus Individuos en la precisión de proceder sin consejo, o de consultar cada uno con el profesor que le acomode entre cuya variedad ni puede guardarse sigilo ni asegurarse el acierto porque raro es aquel profesor que en consultas de esta naturaleza se toma el trabajo de apurar la materia con la misma escrupulosidad que si hubiese de suscribir su dictamen en que se arriesga la conveniencia del público asi

27 Acuerdos, $3^{\mathrm{a}}$, t. VIII, p. 200.

28 Ídem, pp. 197-198.

29 Sobre este episodio véase ídem, $3^{\mathrm{a}}$, t. VIII, pp. 415, 430-436, 464, 499-500 y 507-510. 
por que siendo los capitulares conmunmente legos que no tienen la instrucción de las Leyes que deben observar, ni la practica que necesitan por ser anuales sus empleos como porque teniendo cada uno su peculiar encargo a mas de los asuntos de tanto peso que se ofrecen al Cabildo no pueden imponerse en el corto tiempo con sus muchas ocupaciones.... ${ }^{30}$

Este párrafo medular de la nota al Virrey es revelador acerca de la práctica más reciente. La necesidad del consejo, precioso don que posee el letrado, volvía a ser la raíz de la petición. Pero ese consejo no podía ser en abstracto, suministrado acaso por cualquier hombre de leyes. Era preciso que proviniera de un letrado permanente, experimentado en la tarea capitular y dedicado a ella. Con visible desengaño se aludía al asesoramiento circunstancial o al que recibían particularmente los capitulares de distintos letrados. En una palabra, se reclamaba una dirección letrada para el Cabildo.

La petición no prosperó y el Ayuntamiento se vio obligado a continuar con la mencionada práctica. En 1793 comisionaba a un regidor para que a su vez encargase a un abogado de "probidad e instrucción" la redacción de una representación a la Audiencia, agregando: y "cuantas otras se necesiten en lo sucesivo" ${ }^{31} \mathrm{Al}$ año siguiente se buscaba un letrado para la defensa de las prerrogativas y obligaciones del Cabildo en un juicio. ${ }^{32}$

En 1795 se retomaba la idea de dotar al Cuerpo con una plaza de Abogado. Esta vez era el Síndico Procurador General quien sostenía la necesidad de contar con "un Abogado para seguir los asuntos que diariamente se le ofrecen, pues muchos de ellos permanecen suspensos y otros sin promoverse por falta de Director cierto".

Simultáneamente planteó la conveniencia de designar un archivero para arreglar y facilitar la consulta de los antiguos papeles y reales cédulas. El Cabildo acogió con entusiasmo la iniciativa, al punto que acordó la inmediata designación de uno y otro funcionario. Al recabar el permiso del Virrey, puntualizaba la necesidad de concretar ambas creaciones burocráticas. No sólo destacaba la importancia del auxilio letrado para las tareas rutinarias, sino enfatizaba la necesidad de contar con el "consejero" recomendado por las leyes alfonsíes. De ahí que prefería sugerir que la designación se hiciera bajo el título de "Asesor". 33

30 Ídem, t. X, pp. 135 y 151.

31 Ídem, pp. 239-240.

32 Ídem, pp. 327-328 y 337-338.

33 Ídem, pp. 519-525, 527-528 y 535-537. 
El expediente quedó detenido en las oficinas virreinales. El 22 de diciembre la Contaduría General de Propios y Arbitrios, si bien reconocía la necesidad de contar con las plazas peticionadas, alegaba que no había recursos para satisfacer su dotación. Como por entonces circulaba por las oficinas una petición de fondos del Ayuntamiento, la Contaduría sugería esperar a que se resolviese este último expediente. Así se procedió, pero a partir de entonces ya no se habló más del Asesor o Abogado permanente hasta casi tres lustros después. Ni aun se lo hizo cuando, más adelante, se planteó nuevamente la necesidad de crear otras plazas en el Ayuntamiento. En 1800 aquel expediente de 1795 volvió a las andanzas burocráticas, pero sólo para sustanciar el nuevo pedido de proveer el empleo de archivero. ${ }^{34}$ Y en 1808, el Cabildo se dirigía al rey, interesándole por la confirmación de una resolución gubernativa que aprobaba la creación de nuevas plazas de tesorero, contador, secretario, archivero y portero escribiente. ${ }^{35}$ Del Abogado nada se decía.

¿Cómo se explica este súbito desinterés por la creación del cargo de Abogado o Asesor? A través de las actas capitulares se observa que, hasta principios del nuevo siglo, se mantuvo la práctica de requerir la consulta circunstancial de diversos letrados. En algunos momentos colaboraron especialmente con sus consejos e intervención los doctores José Pacheco y Benito González de Rivadavia, que eran al mismo tiempo regidores. ${ }^{36}$ Pero desde 1803 aproximadamente parece perderse todo rastro de asesoramiento letrado, salvo alguna excepción. Explica en parte este sugestivo vacío el hecho de que a partir de fines de 1805 actuara un letrado como Escribano del Cabildo. Era el licenciado Justo José Núñez. ${ }^{37}$ La presunción es confirmada por el propio ayuntamiento, ya que al abonarle en 1807 los honorarios como notario, se señalaba que su trabajo se había recargado "en clase de profesor del Derecho por las gravísimas y complicadas atenciones” del Cuerpo. Y a fines de ese mismo año, el Cabildo se dirigía al Rey exaltando la personalidad de Núñez y solicitando un premio a sus distinguidos servicios. Decía entonces que el Escribano había servido de "guía y Director al Cabildo" y pedía se le conce-

34 El expediente en AGN, AC., IX.19.4.9, fs. 185-194.

35 AGN, AC., 1808, IX.19.5.9, fs. 20-22, donde se encuentra el borrador.

36 Acuerdos, $3^{\text {a }}$, t. XI, 48, pp. 191-193, 195, 275, 277, 592; 4, t. I, p. 54. Sobre Pacheco y González de Rivadavia, ídem, $3^{\text {a }}$, t. XI, pp. 188-189, 338 y 433-435.

37 José Armando Seco Villalba, Justo José Núñez, Escribano de la Revolución de Mayo, La Plata, 1968, pp. 19, 22 y 25. 
diera "una toga en esta Audiencia si fuese posible, o en otras de las del Reyno" ${ }^{38}$ Como el premio no llegó, Núñez continuó desempeñándose como escribano del Cabildo ininterrumpidamente durante toda la época virreinal y, con algunas interrupciones después de 1810, hasta la extinción del Ayuntamiento en 1821.

Llegamos así a febrero de 1810. El entonces síndico procurador general, doctor Julián de Leyva, qué bien conocía las necesidades del Ayuntamiento en materia letrada, propuso la creación de cuatro plazas de Asesores anuales. Dos dedicadas al asesoramiento de las causas tramitadas ante los alcaldes "con obligación de hacerlo también en los asuntos que se ofrezcan a V.E., al Juzgado de Policía y al Señor Fiel Ejecutor”.

Las otras dos estarían consagradas a las causas de pobres y menores. La propuesta encontró rápido eco en el Cabildo, quien resolvió apoyarla y enviarla al Virrey. Como se advierte, este proyecto no establecía un Abogado o Asesor exclusivo para los asuntos privativos del Ayuntamiento, sino que asignaba esa función a dos letrados que al mismo tiempo atenderían otros asuntos relacionados con la actividad de determinados funcionarios capitulares.

Esta iniciativa fue objetada por el fiscal Genaro de Villota. En su dictamen del 23 de marzo de 1810 admitía sólo la conveniencia de establecer una de las cuatro plazas propuestas, destinada a atender las defensorías de pobres y menores. En cuanto a la asesoría de los juzgados estimaba que era menos gravoso para los fondos públicos el mantenimiento del régimen vigente - en base a los denominados "derechos de firma" - que la dotación de las nuevas plazas. Es decir que, según su criterio, el asesoramiento de los alcaldes no se alteraría, pero en cambio omitía pronunciarse sobre la función reservada al Abogado o Asesor del Cabildo, asunto que, de esta manera, volvía a quedar desplazado.

La agitación de los días y meses siguientes, motivada por el cambio revolucionario, el rumbo desfavorable que había tomado la petición, o alguna otra razón, motivaron el estancamiento del expediente en alguna oficina gubernativa. Sólo ante una reiteración del Cabildo, ${ }^{39}$ el 5 de enero de 1811 la Junta dispuso el pase de las actuaciones a la Audiencia, reanudándose la marcha del expediente hasta culminar, ahora sí, con la resolución definitiva que llegaría a mediados de ese mismo año.

38 Acuerdos, 4a, t. II, pp. 686, 738, 743, 753-754; AGN, AC., 1807, IX.19.5.8, fs. 237-238.

39 Acuerdos, $4^{\text {a }}$, t. IV, p. 323.

$256 \quad$ Capítulo XI 
Sin entrar en los vericuetos del trámite, cabe consignar que, enviado el expediente nuevamente al Cabildo, el síndico procurador general - que ahora era el doctor Miguel de Villegas - apoyó decididamente la petición de Leyva, al tiempo que rebatía el dictamen de Villota. Encontraba que aquella petición tenía apoyo legal y no desperdiciaba la ocasión para utilizar algunos giros adecuados a la nueva situación política, como el acceso de los naturales a los empleos públicos, aunque fundándolo en antiguas disposiciones reales. El Cabildo se adhirió a esta representación del síndico Villegas y, poco después, al requerírsele sobre el monto de la dotación, estableció una retribución algo mayor para los dos abogados que asesorarían a los jueces ordinarios con "la obligación de aconsejar también al Ayuntamiento en los asuntos sobre que les exija su dictamen".

Finalmente la Audiencia, previo dictamen favorable del nuevo fiscal don Agustín Pio de Elía, resolvió aprobar el proyecto capitular, utilizando la expresión "Asesores del Excelentísimo Cabildo y de los Juzgados” para referirse a las dos primeras plazas letradas establecidas. Siguiendo el dictamen de Elía, la Audiencia envió el expediente a la Junta Gubernativa para su noticia y aprobación final. ${ }^{40}$

Como se advierte, sólo sobre el fin del período que consideramos el Cabildo de Buenos Aires alcanzó a establecer un asesoramiento letrado orgánico, en sus diferentes aspectos. La asesoría de Cabildo y de los alcaldes ordinarios, por un lado, a cargo de dos abogados; y la de pobres y menores, a su vez, también atendida por dos letrados, que al mismo tiempo se repartían el asesoramiento de los juzgados de fiel ejecutor y de policía. La asesoría de Cabildo no aparecía en este ordenamiento tan claramente determinada como en anteriores proyectos, ni tenía un letrado exclusivo para sus asuntos. No obstante, no se alejaba de la práctica observada en los anteriores decenios, en cuanto reunía las tareas de asesoramiento del Ayuntamiento con la de los jueces ordinarios. $^{\mathbf{4 1}}$

40 Ídem, t. IV, pp. 45-46, 393-394, 450 y 504. El expediente en AGN, AC, 1810, IX.19.6.2., fs. 68-96.

41 Aunque no se ocupa especialmente del Abogado o Asesor del Cabildo, puede verse acerca del desenvolvimiento del asesoramiento letrado capitular después de 1810 y hasta la extinción del Ayuntamiento a José María Sáenz Valiente, Bajo la campana del Cabildo. Organización y funcionamiento del Cabildo de Buenos Aires después de la Revolución de Mayo (1810-1821), Buenos Aires, 1952, pp. 225-228, 268-270, 274-276 y 335-337. 
Establecidas las líneas generales de esta función letrada y su evolución a través del período virreinal, cabe detenerse en analizar los rasgos esenciales que ofrece a través de los diferentes proyectos y resoluciones.

\section{Denominación y caracterización de la función}

La denominación empleada para designar a la función que venimos estudiando no fue uniforme ni tuvo siempre el mismo significado. Las más utilizadas eran las de "Abogado del Cabildo" ${ }^{\mathbf{4 2}}$ o "Abogado de la Ciudad" ${ }^{43}$ por un lado, y la de "Asesor", ${ }^{44}$ por otro. No faltaba tampoco el uso conjunto de ambos vocablos: "Abogado o Asesor". ${ }^{45} \mathrm{Si}$ en determinadas oportunidades se intentó deslindar lo que era más propio del Asesor - aconsejar o dictaminar - que del Abogado - defender y promover causas -, otras veces ambas palabras se emplearon indistintamente.

La función de asesorar y abogar tanto podía ser desempeñada por un letrado en forma exclusiva, como por quienes tenían a su cargo otras tareas dentro del ámbito capitular. Una práctica frecuente, ya visible en los años anteriores a la erección del Virreinato, recogida en el auto del gobernador Vértiz en 1776 y luego confirmada por la resolución de Sanz en 1783, encomendaba el consejo letrado del Cabildo a los asesores de los alcaldes ordinarios. Este criterio tuvo buena aceptación y fue finalmente adoptado en el proyecto de Leyva de 1810 y en la resolución final de la Audiencia del año siguiente.

Otro criterio era el de establecer un Abogado o Asesor, exclusivamente dedicado a aconsejar al Cabildo y atender sus asuntos, sin compartir su función con otras tareas dentro del ámbito del Ayuntamiento. Este enfoque se aprecia en el proyecto de Escalada de 1784, de la misma naturaleza fue el segundo nombramiento del doctor Carranzio en 1785, y también en la misma orientación se hallaba el proyecto capitular de 1795 .

No faltaban, por último, los que preferían enlazar las funciones del Asesor del Cabildo con las de quien dirigía al síndico procurador general. En tal sentido encontramos la propuesta de Gregorio Ramos, en 1785, y la petición del Cabildo al Virrey de 1792.

42 AGN, AC., 1785, IX.19.3.4, fs. 178; y 19.4.9, fs. 185-194.

43 Acuerdos, $3^{\text {a }}$, t. VII, pp. 534-535, 591; y t.VIII, pp. 197-198, 200.

44 Ídem, $3^{\text {a }}$, t. X, pp. 135, 151.

45 Ídem, $3^{\text {a }}$, t. VII, pp. 437-439. 


\section{Forma y tiempo de la designación}

La designación del Abogado o Asesor era, en principio, atribución del Cabildo. Así ocurría tanto cuando el nombramiento era accidental para un determinado asunto, como cuando se elegía a un letrado permanente. En este último caso, sólo contamos, como elementos de juicio, con las dos designaciones del doctor Carranzio. La primera fue efectuada conjuntamente con las elecciones capitulares del 1 de enero y confirmada por el gobernador intendente. La segunda, de mediados de 1785 , fue sometida también a la aprobación de Sanz. En los proyectos conocidos o en la misma resolución de la Audiencia de 1811 no se aprecia otra forma de designación.

Cabe señalar, no obstante, que la práctica observada durante algún tiempo, en el sentido de que los asesores de los alcaldes ordinarios fueran también los que dictaminaban en asuntos propios del Ayuntamiento, determinaba, en los hechos, que la designación escapaba de las manos de los regidores para concentrarse en las de los alcaldes. Pero, en realidad, esta cuestión no llegó a suscitar problema alguno, tal vez porque los regidores no estaban obligados a admitir el consejo de aquellos asesores y podían valerse de su propio abogado, como ocurrió a veces.

En cuanto al tiempo de la designación, el asunto ofrece mayores dificultades. Dependía, en última instancia, de lo que se pretendía que fuese el Abogado o Asesor. Así quienes preferían asegurar una armonía entre el Ayuntamiento y el letrado se inclinaban hacia la designación anual, con la posibilidad de reelegirlo. En esta línea se ubicaban el auto de Vértiz de 1776 aun cuando no se abordara explícitamente lo relativo a la reelección -, la disposición de Sanz de 1784 y la resolución de la Audiencia de 1811. Dentro de esta misma tendencia estaban quienes se limitaban a señalar que el letrado era amovible "cuando convenga, con causa o sin ella", prevaleciendo el concepto de que lo que necesitaba el Cabildo era "un Abogado de su satisfacción". 46

En cambio, quienes deseaban ver en el Abogado o Asesor a un director letrado del cabildo, que asesorara y guiara a los integrantes del Cuerpo, se inclinaban por una designación "perpetua", "sin limitación de tiempo" ${ }^{\mathbf{4 8}} \mathrm{o}$

46 AGN, AC., IX.19.4.9, fs. 185 yss.

47 Acuerdos, $3^{\text {a }}$, t. VII, pp. 435-436.

48 Ídem, pp. 590-591. 
por un plazo de tres años, ${ }^{49}$ que permitiera dotarlo de una experiencia en el cargo y asegurase una continuidad burocrática, a despecho de la renovación anual de alcaldes y regidores. En tal posición se ubica el proyecto del alcalde Escalada en 1784, al proponer en la nueva planta capitular un asesor perpetuo. Decía entonces que

no puede desconocerse el beneficio que se consigue de que este Abogado Asesor lo sea perpetuo pues el mismo ejercicio y necesidad de extender los acuerdos, y su asistencia a todos, le instruye, tiene noticias cabales para cuales quiera resolución, y proporcionan un procedimiento acorde y consecuente de que no es capaz si se nombrase anualmente por que todo el año se ocupa en adquirir noticias, y al fin se concluye con alguna instrucción, pero sin validad alguna. ${ }^{50}$

\section{Atribuciones. Deberes. Honores}

Es riesgosa la tarea de establecer las atribuciones de un funcionario que, como hemos visto, no estaba nítidamente delineado, y más bien aparecía en medio de un forcejeo entre quienes querían mirarlo más como un Asesor que como un Abogado, o los que intentaban, con un sentido pragmático, amoldar las atribuciones de este letrado a las necesidades capitulares del momento. Resulta pues imprescindible, en pos de la fidelidad histórica, ir analizando esas variantes, que son signos distintivos de la función estudiada.

En el recordado auto del gobernador Vértiz, de 1776, el motivo central de la existencia del Asesor era la consulta de asuntos graves que los individuos del Cabildo no pudieran resolver por defecto de conocimientos jurídicos. En la resolución del gobernador intendente Sanz de 1783, se destacaba la necesidad de proceder "con consejo" en las deliberaciones, especialmente las concernientes al bien público. La idea de la consulta o consejo estaba, sin duda, enmarcada en la mejor línea de la tradición gubernativa castellana e indiana.

En cambio, el proyecto que en 1784 expuso el alcalde Escalada tendía a otorgar un papel más activo al "Abogado Asesor". Así decía:

A imitación de las ciudades principales de España debe tener de necesidad este M.I.C. un individuo en la Clase de Abogado que defienda todas sus causas presentes, y futuras, que forme cuantas representaciones se ofrezcan á el Capítulo; que extienda

49 Ídem, pp. 438-439.

50 Ídem, pp. 435-436. 
sus actas con la formalidad y fuerza debida; que sea a el mismo tiempo su Asesor para cuantos casos le ocurran; que tenga Voto consultivo solamente en los acuerdos, y que esté condecorado con las mismas honras, y prerrogativas que los regidores. ${ }^{51}$

Distinguía muy bien Escalada entre el Asesor existente, proveniente de la resolución de Sanz, y el Abogado - Asesor que proponía, afirmando que al Cabildo mucho le interesaba que a la condición de Asesor se anexara la de Abogado.

$\mathrm{Al}$ año siguiente, al insistir sobre el asunto, el alcalde Ibáñez señalaba la necesidad de contar con "un Abogado con quien hacer las consultas que se ofrezcan y defender cuantos expedientes se hallan pendientes y nuevamente se soliciten en beneficio de la Ciudad". 52 Fue, bajo estas condiciones, que se hizo el nombramiento de José Vicente Carranzio como "Abogado de esta M.I. Ciudad", destacando su actuación anterior como Asesor. El intendente Sanz, al aprobarlo, decía que el designado "habrá de gozar en el dicho Cabildo de las facultades, honores que le son consiguientes con arreglos a Leyes, y a la costumbre que observa el mismo Ilustre Cuerpo" ${ }^{53} \mathrm{Al}$ recibir este decreto, los capitulares dejaron establecido que, entre otros honores, no estaban comprendidos los de Regidor, ya que si originariamente así se había previsto, debía entenderse suspendidos esos honores hasta tanto se crease la nueva planta capitular. ${ }^{54}$

A fines de 1786, el Cabildo, al proponer un nuevo plan presupuestario y expresar la necesidad de mantener el cargo de "Abogado de la Ciudad" decía que el titular del mismo tendría

la precisa obligación de asistir a todos los Acuerdos, defender los Pleitos que la Ciudad tenga, como también todos los negocios pertenecientes a el Común que no sean con aquellos incompatibles, y formar para todos los tribunales las representaciones que se necesiten: en una palabra hacer cuanto se le encargue propio de el Ministerio de Abogado. ${ }^{55}$

Se percibe, a través de esta evolución, una transformación evidente del cargo, que empezó acentuando la tarea de consulta o consejo y se orientó luego hacia una gestión más amplia y un trabajo material más intenso, que en algunos casos llegaba a oscurecer o relegar la función propia del consejero.

51 Ibídem.

52 Ídem, pp. 500-591.

53 Ídem, pp. 615 y 618-619.

54 Ídem, pp. 615-616.

55 Ídem, t. VIII, p. 200.

El Abogado del Cabildo de Buenos Aires durante el Virreinato 
Si nos asomamos a observar el desempeño de las tareas por parte del único Asesor y Abogado permanente que tuvo por entonces el Cabildo, podremos precisar esta transformación que se desprende de los mencionados documentos. Como se recordará, el doctor Carranzio fue al principio - durante un año y nueve meses - Asesor a tenor de la resolución del intendente Sanz de fines de 1783. Con posterioridad pasó a ser Abogado-Asesor. Mientras ejerció el primer cargo, su papel era más pasivo, no firmaba los acuerdos y al parecer tampoco concurría a los mismos, de manera distinta a lo que había sucedido con su lejano antecesor, el licenciado Pastor.

En la segunda época de su actuación en el Cabildo, la participación de Carranzio fue más activa. Recurramos para ello al testimonio del alcalde de segundo voto actuante en 1786, dado cuando el honor de Carranzio apareció comprometido por la acusación de que había tratado de obligar a los capitulares a que siguiesen sus opiniones. Decía entonces aquél que

nunca advirtió en dicho Dr. que compeliese ni estrechase a los Señores Vocales a que conviniesen con su dictamen: Al contrario, todo su empeño se reducía a instruirles en los antecedentes, y en las consecuencias para que pudiesen con mas conocimiento dar su Voto como lo hicieron libremente y así se advertirá en las Actas Capitulares las diferentes opiniones, de que muchas veces fueron: habiendo conseguido este M.I.C. la satisfacción de que cuando concurrió dicho Dr. a los Acuerdos se evacuaron los negocios por graves que fuesen con la mayor brevedad pulso y acierto...

Y finalmente subrayaba que

es muy necesaria la asistencia de el expresado Dr. a los Cabildos, asi por lo muy impuesto que está en todos los asuntos pendientes en que tanto se interesa el bien público como para que dirija y extienda sus Actas Capitulares con el método y arreglo que corresponde, evitándose por este medio la confusión, y no caer en ninguna inconsecuencia. ${ }^{56}$

Al suscitarse el recordado incidente y negarse Carranzio a colaborar con el Cabildo, éste le mandó decir que

supuesto que se tiene por Abogado de el, y que como tal concurre a todas las funciones y actos públicos en cuerpo de Cabildo, se sirva extender con la mayor brevedad este y cuantos Informes están detenidos, y demás que en lo sucesivo se ofrezcan.

Estos elementos de juicio permiten afirmar que esa transformación entre el simple Asesor y el Abogado Asesor se había producido en el corto tiempo en que Carranzio ejerció sucesivamente esos empleos.

56 Ídem, pp. 507-508.

262 Capítulo XI 
Con la petición del Cabildo al virrey, en 1792, se volvió otra vez a la figura anterior del Asesor, en la que se remarcaba la importancia del consejo o consulta. ${ }^{57}$ Pero en el proyecto de 1795 se aunaban ambos aspectos de manera singular. Así se hablaba reiteradamente del Abogado, pero, a la hora de darle título al funcionario, se prefería el de Asesor. También se discurría largamente sobre la importancia del "consejo de personas literatas", pero asimismo se hacía una prolija enumeración de los deberes que debía llenar el letrado a elegir. En este último sentido, se especificaba qué era lo que debía hacer este Asesor:

extender los acuerdos, informes, oficios y representaciones que ocurran de cualquier clase que sean, prestar sus dictámenes cuando se le pidan por el Cabildo y Junta Municipal de Propios bien sea por escrito, de palabra, concurriendo a la Sala Capitular cuando se le llama y a todas las funciones de cualesquiera clase que sean y actos públicos, teniendo asiento después del Síndico Procurador, como también el defender las causas y negocios que por si mismo agitase así el Cabildo como la Junta Municipal de Propios, y en que no tuviese intervención el Procurador Síndico... ${ }^{58}$

Posiblemente las necesidades del momento hicieron pensar en la conveniencia de reunir en el letrado algunas obligaciones propias de un secretario del cuerpo. Cabe preguntarse si estas detalladas funciones no encontraron años después su buen ejecutante en el licenciado Justo José Núñez, Escribano del Ayuntamiento durante varios lustros, e hicieron ocioso pensar en un letrado que atendiera los asuntos capitulares.

Ya sea por lo indicado, o por otras razones, lo cierto fue que cuando en 1810 el síndico procurador general Leyva, al presentar su recordado proyecto, y luego el Cabildo, al hacerlo suyo y reiterarlo, aludían a la obligación de los abogados de "aconsejar también al Ayuntamiento en los asuntos sobre que les exija su dictamen". ${ }^{59} \mathrm{Al}$ aprobar el proyecto, la Audiencia se refería lacónicamente a los "Asesores del Excelentísimo Cabildo" y declaraba que tendrían "asiento en toda concurrencia pública y privada a que asistiesen" ${ }^{\mathbf{0}}$

Los dos aspectos fundamentales observados a través de esta evolución, es decir el asesoramiento y la práctica de abogar, se perciben también en las ocasiones en que el Ayuntamiento requería el auxilio de algún letrado, ya

57 Ídem, t. X, pp. 135 y 151.

58 AGN, AC., IX.19.4.9, fs. 185-194.

59 Ídem, IX.19.6.2.

60 Ibídem. 
fuese para recibir su consejo, ya para redactar cartas o representaciones importantes, ya para defender al Cabildo en juicio, etc.

Como se advierte pues, tanto en los proyectos como en la práctica, el Asesor o Abogado del Cabildo estuvo destinado a desempeñar tareas que, enmarcadas dentro de aquellos dos aspectos fundamentales, se adaptaban a las necesidades de cada momento de la vida capitular.

\section{La retribución}

Al ocuparnos de este tema interesa señalar dos aspectos: el del monto de la retribución para determinar hasta qué punto se trataba de una plaza codiciada por los letrados; y sobre quién o qué rubro fiscal recaía el pago.

El monto de la retribución no era atrayente para un letrado, sobre todo si sus obligaciones aumentaban de tal manera que lo convertían en un funcionario que debía dedicar cierta atención y buen tiempo al despacho de los negocios capitulares. Recuérdese que, casi siempre, la labor de asesorar al Ayuntamiento iba unida con otras tareas menudas propias del abogado o con el asesoramiento letrado de los jueces ordinarios.

La retribución no era baja si la contemplamos desde la perspectiva de las erogaciones capitulares, ya que el Cabildo encontraba a veces dificultades para hacer frente a un sueldo de esta naturaleza. Pero no resiste la comparación con los sueldos que percibían por entonces los funcionarios de gobierno y hacienda.

En 1773 y 1774 se pagaron cien pesos anuales al letrado encargado de los asuntos capitulares "aunque - decía el acta respectiva - parece se debía regular más”. ${ }^{61}$ En 1775 se le abonó trescientos cincuenta pesos. ${ }^{62} \mathrm{El}$ intendente Sanz fijó en 1783 un sueldo anual de 250 pesos, y con posterioridad, a través de peticiones y proyectos, fue oscilando entre 400 y 600 pesos, hasta llegar a esta última cifra en el proyecto capitular aprobado por la Audiencia en 1811. La evolución no es significativa teniendo en cuenta el alza de precios operado en ese cuarto de siglo.

Los 250 pesos iniciales representaban, en su momento, aproximadamente la décima parte de lo que percibía el Secretario del Virreinato, la duodécima parte de lo que cobraba el Asesor del Virreinato y Auditor de Guerra, y la

61 Acuerdos, $3^{\text {a }}$, t. IV, p. 698, y t.V, p. 214.

62 Ídem, t.V, p. 569. 
cuarta parte de lo que correspondía al oficial primero de aquella Secretaría. ${ }^{63}$ Si bien estos funcionarios soportaban sobre sí una pesada carga en su labor burocrática, que los inhibía de ocuparse de otras tareas, también es cierto que constantemente se reproducían quejas por los bajos sueldos que percibían.

Si el magro sueldo del Abogado del Cabildo podía provocar el desinterés de los letrados por ocupar la plaza, no hay que olvidar la existencia de otros factores que contribuían a frenar ese desaliento. El brillo y poder del Cabildo, aun cuando para entonces estuviera en mengua, aseguraba al letrado una provechosa relación. Así se explica, por ejemplo, que el doctor Tomás Antonio Valle se presentara al Cabildo en 1806 expresando sus deseos de ser designado Asesor permanente de uno de los alcaldes, en el caso de que se tratase de nombrarlos con ese carácter. Valle agregaba que estaba dispuesto a desempeñarse sin retribución, hasta que los fondos públicos lo permitieran. No era por cierto, el doctor Valle un principiante sino que para avalar su postulación, exhibía antecedentes que lo vinculaban con el Cabildo en los últimos veinte años, en forma discontinua, como asesor de los alcaldes, del síndico general y del defensor de pobres. ${ }^{64}$

En esta época era aún tema controvertido el determinar si las retribuciones de algunos auxiliares de los funcionarios de gobierno y de Cabildo debían recaer sobre las arcas reales o capitulares o sobre las particulares de los funcionarios interesados. $\mathrm{Al}$ irse delineando con cierta nitidez una burocracia administrativa, fue afirmándose la idea de que la renta debía salir del erario público. Esta misma concepción empezó a imponerse en el Cabildo, con respecto a los asesores de los alcaldes, el síndico procurador general y el defensor de pobres. En cambio, por la propia naturaleza de la función del Asesor o Abogado - que actuaba en beneficio de todo el Cuerpo -, no llegó a plantearse en nuestro caso y siempre fue considerada como una carga concejil, ya se tratase de honorarios por determinados asuntos o ya fuera una retribución fija.

63 He utilizado las retribuciones indicadas por Mariluz Urquijo, Orígenes..., p. 95; y "El asesor...", cit., pp. 193-194.

64 AGN, AC., 1806, IX.19.5.5, fs. 406. 


\section{Epílogo ${ }^{65}$}

Como conclusión se pueden agregar unas líneas acerca del interés que tiene este aporte para observar y alcanzar un panorama más amplio y preciso de la función desempeñada por el jurista castellano-indiano y en este caso su significación en las actividades de gobierno y justicia en el nivel local.

La figura del letrado asomaba cada vez como más necesaria dentro de la compleja estructura burocrática en una etapa de crecimiento general administrativo, particularmente señalada en el flamante Virreinato rioplatense.

Esto ocurría en tiempos en que se manifestaba con mayor fuerza la intensa presión de las autoridades reales por imponer la aplicación de la normativa regia - tanto la proveniente de la Península como la que dictaban virreyes, intendentes, etc. Tal pretensión produjo momentos de conflictividad con órganos y autoridades locales, entre las cuales se destacaba el Cabildo, como cuerpo representativo de la ciudad, sobre todo cuando aquella normativa avanzaba desconociendo el orden jurídico local, antiguo y escasamente formalizado en textos de índole legal.

Como tuve ocasión de exponer en otro trabajo ${ }^{\mathbf{6 6}}$ ese orden constaba de varios elementos y era el que disponía la ciudad para su gobierno propio. A una débil consistencia formal contraponía un vivo entramado socio-jurídico que bajo la denominación de "fuero" reunía normas y privilegios fundacionales, usos, costumbres, privilegios, preeminencias, excepciones, etc., que muchas veces no estaban respaldadas por textos escritos, pero que eran invocados con convicción cuando la ocasión lo requería. Aunque el Cabildo, desde tiempos antiguos, había sido en general buen custodio de esta tradición, es posible que por entonces hubiese surgido la necesidad de redoblar la resistencia para mantener tal ordenamiento.

En esta situación resultaba imprescindible conocer, rescatar y reinvindicar ese conjunto normativo a través de representaciones, defensas u otros papeles de índole jurídica y judicial, que desbordaban la habitual capacidad de un alcalde o regidor y exigía la intervención de un hombre de Derecho con conocimientos de ese esquivo "derecho local".

65 Agregado del autor para esta edición.

66 Víctor TAu Anzoátegui, “Órdenes normativos y prácticas socio-jurídicas. La justicia”, en Academia Nacional de la Historia, Nueva Historia de la Nación Argentina, Editorial Planeta, Buenos Aires, t. II, pp. 298-300. 
Buen ejemplo de esta situación son las vicisitudes que se produjeron en el cabildo de una ciudad periférica, como Buenos Aires, aunque elevada de rango por formar parte de una flamante centralidad virreinal, para introducir la función letrada en su ámbito con carácter más o menos permanente. Como vimos, fue una cuestión que llevó bastante tiempo resolver ante las distintas posturas expresadas por los capitulares y autoridades. La solución que se fue tejiendo tenía diversos entramados o alternativas dados los aspectos que se consideraban. Desde la misma denominación de la función Asesor o Abogado o ambas a la vez - hasta el alcance que se pretendía con ella - asesoramiento simple o actuación profesional en causas y negocios - fueron propuestas con diverso éxito hasta que se acabó de delinear una idea más completa de aquella función con la figura del Abogado Asesor.

Constituido éste en un guía de la actividad capitular en asuntos de gobierno y justicia con asiento asignado en el Cabildo, lo llevó a dirigir y extender las actas capitulares y demás documentos - informes, oficios y representaciones de cualquier clase. Función ésta que al fin desempeñó un letrado como Escribano del cuerpo, que fue el licenciado Justo José Núñez desde fines de 1805 , sin perjuicio de las intervenciones ocasionales de otros letrados.

Un seguimiento de este tema en la década posterior a 1810 en el cabildo de Buenos Aires y en otros cabildos de la región puede arrojar nuevos datos que ayuden a esclarecer el significado alcanzado por la función de los letrados en ese período de transición, especialmente en relación a la afirmación de un orden jurídico local. 



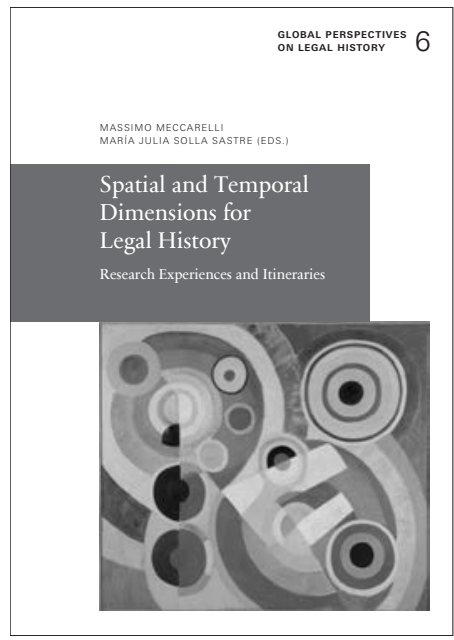

Massimo Meccarelli,

María Julia Solla Sastre (eds.)

Spatial and Temporal Dimensions for Legal History

Research Experiences and Itineraries

Global Perspectives on Legal History 6

Frankfurt am Main: Max Planck Institute for European Legal History 2016.

300 p., € 14,99 D

ISBN 978-3-944773-05-6

Open Access Online Edition:

http://dx.doi.org/10.12946/gplh6

The spatiotemporal conjunction is a fundamental aspect of the juridical reflection on the historicity of law. Despite the fact that it seems to represent an issue directly connected with the question of where legal history is heading today, it has still not been the object of a focused inquiry. Against this background, the book's proposal consists in rethinking key confluences related to this problem in order to provide coordinates for a collective understanding and dialogue. 
Global Perspectives on Legal History is a book series edited and published by the Max Planck Institute for European Legal History, Frankfurt am Main, Germany. As its title suggests, the series is designed to advance the scholarly research of legal historians worldwide who seek to transcend the established boundaries of national legal scholarship that typically sets the focus on a single, dominant modus of normativity and law.

The series aims to privilege studies dedicated to reconstructing the historical evolution of normativity from a global perspective.

It includes monographs, editions of sources, and collaborative works. All titles in the series are available both as premium print-on-demand and in the open-access format.

\section{Released volumes}

6 | Massimo Meccarelli, María Julia Solla Sastre (eds.)

Spatial and Temporal Dimensions for Legal History.

Research Experiences and Itineraries

4 | Osvaldo Rodolfo Moutin

Legislar en la América hispánica en la temprana edad moderna.

Procesos y características de la producción de los Decretos del Tercer Concilio Provincial Mexicano (1585)

3 | Thomas Duve, Heikki Pihlajamäki (eds.)

New Horizons in Spanish Colonial Law.

Contributions to Transnational Early Modern Legal History

2 | María Rosario Polotto, Thorsten Keiser, Thomas Duve (eds.)

Derecho privado y modernización.

América Latina y Europa en la primera mitad del siglo XX

1 | Thomas Duve (ed.)

Entanglements in Legal History: Conceptual Approaches

More information on the series and forthcoming volumes: http://global.rg.mpg.de 



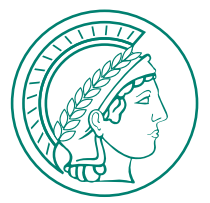

This study of the history of Derecho Indiano proposes to analyze the role played by the Spanish-American jurist in the New World, as both elaborator as well as a practitioner of an art and a practice. While contributing to the development of public authority within a new society, the jurist faced episodes, realities, and circumstances of huge diversity. The studies collected in this volume appeared originally in journals and collected works in various countries. They are offered today in a revised edition.

\section{http://global.rg.mpg.de}

ISBN 978-3-944773-06-3 